\title{
DETERMINISM IN THE BOOK OF ECCLESIASTES
}

\author{
Dominic Rudman
}
A Thesis Submitted for the Degree of PhD at the University of St Andrews

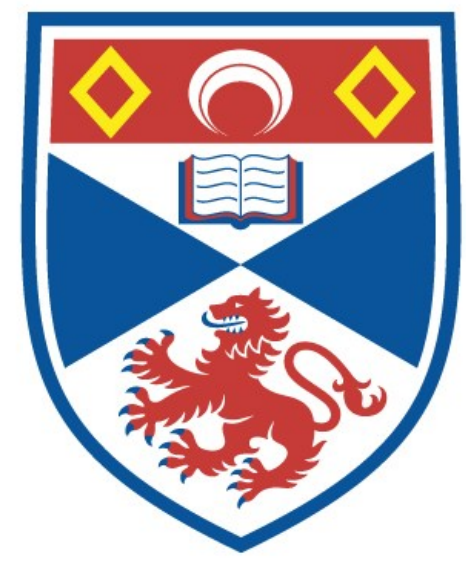

1998

Full metadata for this item is available in

St Andrews Research Repository

at:

http://research-repository.st-andrews.ac.uk/

Please use this identifier to cite or link to this item: http://hdl.handle.net/10023/13794

This item is protected by original copyright 


\title{
DETERMINISM IN THE BOOK OF ECCLESIASTES
}

by

\author{
Dominic Rudman
}

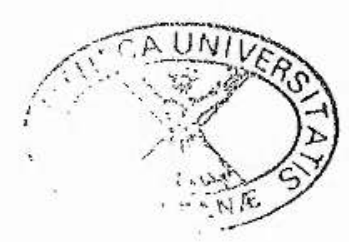

A Thesis

submitted to the School of Divinity,

The University of St. Andrews, in

fulfilment of the requirement for the

degree of

DOCTOR OF PHILOSOPHY

St. Andrews, Scotland

August 1997 
ProQuest Number: 10166435

All rights reserved

INFORMATION TO ALL USERS

The quality of this reproduction is dependent upon the quality of the copy submitted.

In the unlikely event that the author did not send a complete manuscript and there are missing pages, these will be noted. Also, if material had to be removed, a note will indicate the deletion.

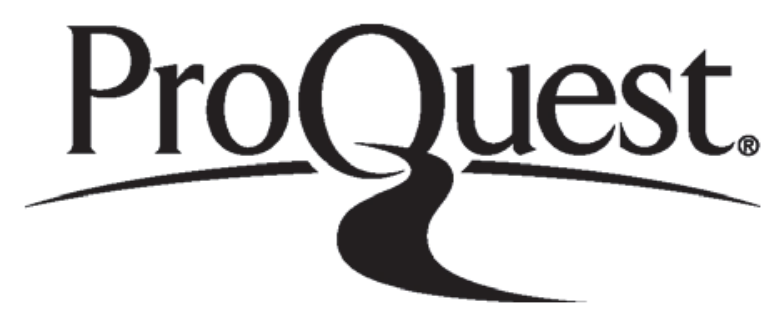

ProQuest 10166435

Published by ProQuest LLC (2017). Copyright of the Dissertation is held by the Author.

All rights reserved.

This work is protected against unauthorized copying under Title 17, United States Code Microform Edition (C) ProQuest LLC.

ProQuest LLC.

789 East Eisenhower Parkway

P.O. Box 1346

Ann Arbor, Ml $48106-1346$ 
Th $C_{4}{ }^{4}$ 
"What is the greatest thing you can experience? It is the hour of the great contempt.The hour in which even your happiness grows loathsome to you, and your reason and your virtue also." (Friedrich Nietzsche, Also Sprach Zarathustra) 


\section{STATEMENT AND DECLARATION}

I, Dominic Christiaan Rudman, hereby certify that this thesis, which is approximately 80000 words in length, has been written by me, that it is the record of work carried out by me and that it has not been submitted in any previous application for a higher degree.

\section{August 1997}

Date

Dominic Rudman

I was admitted as a research student in October 1994 under Ordinance 350 (General No. 12) and as a candidate for the degree of Doctor of Philosophy under the Resolution of the University Court 1967, No. 1 (as amended) in March 1995; the higher study for which this is a record was carried out in the University of St. Andrews between October 1994 and August 1997.

\section{Angust 1997}

Date

Dominic Rudman 


\section{CERTIFICATE}

I hereby certify that DOMINIC CHRISTIAAN RUDMAN has fulfilled the conditions of the Resolution and Regulations appropriate to the degree of Doctor of Philosophy in the University of St. Andrews and that he is qualified to submit this thesis in application for that degree.

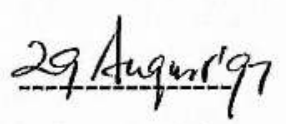

Date
Robert B. Salters

\section{COPYRIGHT}

In submitting this thesis to the University of St. Andrews, I understand that I am giving permission for it to be made available for use in accordance with the regulations of the University Library for the time being in force, subject to any copyright in the work not being affected thereby. I also understand that the title and abstract will be published, and that a copy of the work may be made and supplied to any bona fide library or research worker. 


\section{ACKNOWLEDGEMENTS}

First and foremost, I should like to express my thanks to my supervisor, Dr. Robert Salters, for his attentive interest and encouragement throughout the construction of this thesis. His experience of wrestling with the book of Ecclesiastes, and his willingness to share that experience, has been invaluable to me in the course of my studies.

My thanks must also go to Professors Ferdinand Deist, Aelred Cody, Jouette Bassler, and Antoon Schoors of the Journal of Northwest Semitic Languages, Catholic Biblical Quarterly, Journal of Biblical Literature, and Bibliotheca Ephemeridum Theologicarum Lovaniensium respectively, for permission to use my forthcoming articles "The Translation and Interpretation of Ecclesiastes 8:17a", "A Note on the Dating of Ecclesiastes", "Woman as Divine Agent in Ecclesiastes", and "The Anatomy of the Wise Man: Wisdom, Sorrow and Joy in the Book of Ecclesiastes" and/or material therefrom for the substance of Chapters 4, 5, 6 and 7 of this thesis. Two further articles on Ecclesiastes came about as a result of work carried out in the course of my studies but are not reproduced here: "A Contextual Reading of Ecclesiastes 4:13-16," JBL 116 (1997) 57-73 and "Qohelet's Use of לפבי," $J N S L 23 / 2$ (1997). I owe a debt of gratitude to the unknown reviewers of all of these articles, whose helpful comments have contributed in no small measure to my own attempts to understand Qohelet's work.

Finally, I would like to express my appreciation of a research grant from the British Academy which has made this study possible and of a number of awards from the Dickie Fund administered by St. Mary's College. 


\section{CONTENTS}

QUOTATION $\quad$.............................................. i

STATEMENT AND DECLARATION

COPYRIGHT, CERTIFICATE

ACKNOWLEDGEMENTS

CONTENTS

ABBREVIATIONS

ABSTRACT

I ECCLESIASTES AND ITS HELLENISTIC CONTEXT $\quad \ldots . .1$

II QOHELET AND FATE $\quad \ldots . .25$

III “A TIME TO GIVE BIRTH, A TIME TO DIE": A RESPONSE TO BLENKINSOPP $\quad \ldots . .90$

IV THE WORK OF GOD $\quad \ldots . .109$

V QOHELET AND THE PROBLEM OF FREE WILL $\quad \ldots . .121$

VI WOMAN AS DIVINE AGENT IN ECCLESIASTES $\quad \ldots . .141$

VII "A TIME TO LAUGH": QOHELET AND HUMAN JOY $\quad$.....164

VIII DETERMINISM AND EARLY JEWISH LITERATURE $\quad$.....184

IX QOHELET AND STOIC DETERMINISM $\quad . . .199$

$\mathrm{X}$ CONCLUSION $\quad \ldots . .233$

BIBLIOGRAPHY 


\section{ABBREVIATIONS}

$\mathrm{AB}$

$A B D$

Adv. Math.

Adv. Val.

Aet. mundi

AHW

ANET

Apoc. Abr.

2 Apoc. Bar.

As. Mos.

ATD

ATSAT

AV

$b$.

$B A$

BASOR

B. Bath

B.C.E.

BDB

BETL

BHS

Bib

B. Kam

BKAT

BZAW

$C A D$

Cant
Anchor Bible

D. N. Freedman (ed.), Anchor Bible Dictionary

Sextus Empiricus, Adversus mathematicos

Tertullian, Adversus Valentinem

Philo, De aeternitate mundi

W. von Soden, Akkadisches Handwörterbuch

J. Pritchard (ed.), Ancient Near Eastern Texts

Apocalypse of Abraham

Apocalypse of Baruch

Assumption of Moses

Das Alte Testament Deutsch

Arbeiten zu Text und Sprache im Alten Testament

Authorised Version

Babylonian Talmud

Biblical Archeologist

Bulletin of the American Schools of Oriental Research

Baba Bathra

Before Common Era

Brown-Driver-Briggs,

Hebrew and English Lexicon of the Old Testament

Bibliotheca Ephemeridum Theologicarum Lovaniensium

Biblica Hebraica Stuttgartensia

Biblica

Baba Kamma

Biblische Kommentar: Altes Testament

Beiheft zur ZAW

The Assyrian Dictionary of the Oriental Institute of the

University of Chicago

Canticles 
$C B Q$

CD

C.E.

1, $2 \mathrm{Chr}$

Comm. not.

CSIC

C.U.P.

D.

De stoic. repugn.

De pra. har.

Deut

Div. inst.

DL

Eccl

ed.

EncJud

Eng.

ErIsr

EstBíb

Exod

Ezek

Fuga

Gen

GKC

$H A R$

HAT

HB

Hdt.

Heres

Hist. Nat.
Catholic Biblical Quarterly

Cairo (Genizah) Damascus Document

Common Era

1, 2 Chronicles

Plutarch, De communibus notitiis

Consejo Superior de Investigaciones Científicas

Cambridge University Press

H. Diels (ed.), Die Fragmente der Vorsokratiker

Plutarch, De stoicorum repugnantiis

Tertullian, De prascriptis hareticis

Deuteronomy

Lactantius, Divina institutiones

Diogenes Laertius

Ecclesiastes

editor

Encyclopedia Judaica

English

Eretz Israel

Estudios Bîblicos

Exodus

Ezekiel

Philo, De fuga et inventione

Genesis

E. Kautzsch (ed.),

Gesenius' Hebrew Grammar (Trans. A. E. Cowley)

Hebrew Annual Review

Handbuch zum Alten Testament

Hebrew Bible

Herodotus

Philo, Quis rerum divinarum heres

Pliny, Historia naturalia 
viii

HKAT

$H R$

HTR

HUCA

Ibid.

ICC

IG

Isa

JAOS

JB

Jon

$J B L$

Jdt

JHI

JNES

$J N S L$

Josh

$J Q R$

JSOT

JSOTSup

$J S S$

JTS

Judg

$J . W$.

KAT

Ketub.

1, $2 \mathrm{Kgs}$

KJV

Leg All

Lev
Handkommentar zum Alten Testament

History of Religions

Harvard Theological Review

Hebrew Union College Annual

Ibidem

International Critical Commentary

Preussische Akademie des Wissenschaften zu Berlin (ed.), Inscriptiones Graecae

Isaiah

Journal of the American Oriental Society

Jerusalem Bible

Jonah

Journal of Biblical Literature

Judith

Journal of the History of Ideas

Journal of Near Eastern Studies

Journal of Northwest Semitic Languages

Joshua

Jewish Quarterly Review

Journal for the Study of the Old Testament

Journal for the Study of the Old Testament-Supplement Series

Journal of Semitic Studies

Journal of Theological Studies

Judges

Josephus, Jewish War (=Bellum Judaicum)

Kommentar zum Alten Testament

Ketuboth (Talmud)

1, 2 Kings

King James Version

Philo, Legum Allegoriae

Leviticus 
LSJ

LXX

1, 2 Macc

Midr. Qoh.

MT

MUSKTF

n.

NAB

Naz.

NCBC

NEB

Neh

NIV

NRSV

NT

Num

NZSTh

OT

OTG

OTL

PColZen

PCZ

Prov

P. Lips.

Praep. Evang.

$P S B$ NS
Liddell-Scott-Jones, Greek-English Lexicon

Septuagint

1,2 Maccabees

Midrash Qohelet

Masoretic Text

Münchener Universitätsschriften Katholisch-Theologische

Fakultät

Footnote

New American Bible

Nazir (Talmud)

New Century Bible Commentary

New English Bible

Nehemiah

New International Version

New Revised Standard Version

New Testament

Numbers

Neue Zeitschrift für systematische Theologie und

Religionsphilosophie

Old Testament

Old Testament Guides

Old Testament Library

W. L. Westermann \& E. S. Hasenoehrl (eds.),

The Zenon Papyri, Business Papers of the Third Century

dealing with Palestine and Egypt

O. Guérand \& P. Jouguet (eds.),The Zenon Papyri

Proverbs

L. Mitteis (ed.),

Griechische Urkunden der Papyrussammlung zu Leipzig

Eusebius, Praparatio Evangelica

Princeton Seminary Bulletin, New Series 
Rab. Rabbah

RA Revue d'Assyriologie et d'Archaologie Orientale

$R B \quad$ Revue biblique

REB Revised English Bible

RSV Revised Standard Version

RV Revised Version

1,2 Sam 1,2 Samuel

SCM Student Christian Movement

Sir Ben Sira

Somn Philo, De Somniis

SPCK Society for Promoting Christian Knowledge

Strom. Clement of Alexandria, Stromateis.

SVF G. Von Arnim (ed.), Stoicorum Veterum Fragmenta

t. Tosefta

TDNT G. Kittel and G. Friedrich (eds.),

Theological Dictionary of the New Testament

TDOT G. J. Botterweck and H. Ringgren (eds.),

Theological Dictionary of the Old Testament

TECC Textos y Estudios Cardenal Cisneros

Tg. Targum

UF Ugarit Forschungen

VF Verkïndigung und Forschung

$\mathrm{Vg} \quad$ Vulgate

VT Vetus Testamentum

VTSup Vetus Testamentum, Supplement Series

WBC Word Biblical Commentary

Wis Wisdom of Solomon

y. Jerusalem Talmud

ZAW Zeitschrift für die alttestamentliche Wissenschafi

ZDMG Zeitschrift für die deutschen morgenländischen Gesellschaft

ZDPV Zeitschrift des deutschen Palästina Vereins 
xi

ZWT Zeitschrift für wissenschaftliche Theologie 


\begin{abstract}
This thesis considers the evidence for current assertions that the book of Ecclesiastes is a deterministic work composed during the Hellenistic period. It reviews the linguistic and socioeconomic arguments for its dating either to Persian or Hellenistic times, and concludes in favour of the latter (Chapter 1). An examination of key terms occurring in passages thought to be deterministic follows. The contexts in which these terms are used support the thesis that Qohelet was a determinist, and that this concept is expressed in the catalogue of seasons in 3:1-8 (Chapter 2).

Recently, Joseph Blenkinsopp has challenged deterministic readings of 3:1-8 on new grounds: this thesis provides a response to the specific criticisms raised by his article (Chapter 3). Thereafter, it goes on to discuss the question of whether "the work of God" and "the work which is done under the sun" are equivalent, providing fresh evidence is produced to demonstrate that this is indeed the case (Chapter 4), and offering a new explanation as to how Qohelet may have reconciled the concept of determinism with free will (Chapter 5). Thereafter, it considers the activity of God in the sphere of human emotions and concludes that the ultimate decision not just about what human beings do, but about what they feel, rests with God (Chapters 6, 7).

Finally, this thesis views the determinism of Ecclesiastes against its Jewish background and possible Stoic sources: it reaches the conclusion that Qohelet's thought and manner of expression is fundamentally Hebraic but that he probably had some knowledge of Stoic determinism as well (Chapters 8, 9). The apparent connection with early Jewish deterministic texts and Stoicism supports the current consensus that the book of Ecclesiastes was composed in the period 250-225 B.C.E..
\end{abstract}




\section{Chapter 1 \\ Ecclesiastes and its Hellenistic Context}

\section{Introduction}

Despite the identification made in early Jewish and Christian exegesis, 1 it is generally accepted today that Solomon was not the author of the book of Ecclesiastes. The reasons for this early identification of Qohelet with Solomon hinged largely on the editorial superscription to the book in 1:1, in which Qohelet is described as "the son of David, king in Jerusalem" and on Qohelet's own words in 1:12 in which he describes himself as "king over Israel in Jerusalem." Only two kings (David and Solomon) are noted to have ruled Israel from Jerusalem. Thereafter, the northern tribes broke away from the union, leaving Jerusalem the capital of Judah (1 Kgs 12:16-20) and ruled by the Davidic line.

The identification of Qohelet as "David's son" (i.e. Solomon) in the later superscription of 1:1 however, is not made in 1:12 nor anywhere else in Ecclesiastes. Nevertheless, it most likely arose from the description of the so-called "Royal Experiment" in 1:12-2:12 where Qohelet experiences all the trappings of wealth and pleasure appropriate to a king. 2 The depiction of the various luxuries enjoyed by Qohelet is reminiscent of the Solomonic court (1 Kings 10). This identification was made easier still for the editor by Qohelet's claim to have "increased in wisdom, more than all who were in Jerusalem before me." Again, this was a statement which called to mind Solomon's legendary wisdom (1 Kgs 5:9-14 [Eng. 4:29-34]). Most modern commentators would agree however, that although the "Royal Experiment" in 1:12-2:12 may be intended to recall the glory of Solomon, Qohelet seems not to

\footnotetext{
1Tg. Qoh. 1:1; 1:12; Midr. Qoh. to 1:1, 12; Clement of Alexandria, Strom. 6.11, 14, 15; Tertullian, Adv. Val. 2; De Pra. Hoer. 7.

2 R. N. Whybray, Ecclesiastes (NCBC; Grand Rapids: Eerdmans; London: Marshall, Morgan \& Scott, 1989) 34 .
} 
have wished to cultivate the impression that the author of his work was Israel's most famous king. ${ }^{3}$

Although the 17 th Century scholar Grotius is sometimes noted as being the first to suggest the unlikelihood of Solomonic authorship for Ecclesiastes, this distinction in fact belongs to Luther. ${ }^{4}$ The conclusions of both in this regard were followed eagerly in the 19th century and indeed it has now become almost a cliche to cite the words of Franz Delitzsch in this regard: "If the book of Koheleth were of old Solomonic origin, then there is no history of the Hebrew Language."5

If Solomon be not the author of Ecclesiastes, when was the book actually written? Theories of the date of authorship vary wildly. E. Renan argued for a date as late as the first century B.C.E.. 6 This has now been ruled out by the discovery of Qohelet scroll fragments at Qumran, the earliest of which (4QQoha) has been dated to the mid-second century B.C.E.. ${ }^{7}$ This provides a terminus ante quem for the work. In addition, many scholars have asserted some form of dependence for Ben Sira on Ecclesiastes. 8 Taking the date of Ben Sira as 180 B.C.E., this would suggest a date for the composition of Ecclesiastes prior to 200 B.C.E.. A terminus post quem is suggested by the high proportion of Aramaisms and the appearance of two Persianisms in the book. Both point to a postexilic date.

\footnotetext{
3 R. Gordis, Koheleth: The Man and His World (New York: Bloch, 1968) 60.

$4 \mathrm{H}$. Grotius (Annotationes in Vetus Testamentum [ed. G. Vogel; Halae: Curt, 1875-76] 1.434-35) grounded his conclusions on the high proportion of Aramaisms in the book, pointing to a postexilic date. Luther (Tischreden, LIX. 6) ascribed authorship to Sirach and described it as a Talmud, probably composed from books in the library of Ptolemy IV Euergetes.

5 F. Delitzsch, Commentary on the Song of Songs and Ecclesiastes (Leipzig: Dörffling \& Franke, 1875; Edinburgh: Clark, 1877; reprint, Grand Rapids: Eerdmans, 1982) 190.

$6 \mathrm{E}$. Renan, L'Ecclésiaste traduit de l'Hébreu avec une étude sur l'age et le caractère du livre (Paris: Levy, 1882) 51-54.

7 J. Muilenberg, "A Qoheleth Scroll from Qumran," BASOR 135 (1954) 20-28; F. M. Cross, "The Oldest Manuscripts from Qumran," JBL 74 (1955) 153, 162.

8 C. H. H. Wright, The Book of Koheleth (London: Hodder \& Stoughton, 1883) 41-46; T. Nöldeke, "Bemerkungen zum hebräischen Ben Sira," ZAW 20 (1900) 81-94; A. H. McNeile, An Introduction to Ecclesiastes (Cambridge: C.U.P., 1904) 34-37; G. A. Barton, Ecclesiastes (ICC; Edinburgh: Clark, 1908) 53-56.
} 
The current scholarly consensus would make Ecclesiastes a product of the early Hellenistic period, probably around 250 B.C.E.. 9 This dating is based largely on socioeconomic evidence, but also to some extent on the grounds of the alleged presence of Greek thought in Qohelet's work. Other scholars have argued that the reported parallels between the work of Qohelet and Greek thought are so general as to provide no evidence whatsoever for a date in the Hellenistic period. Citing the lack of grecisms in Ecclesiastes as additional evidence for their view, dates in the Persian period have been proposed where the socioeconomic evidence is said to tally with the social background presupposed by the book. 10 This introductory chapter will therefore examine the linguistic and socioeconomic evidence before Qohelet's worldview is discussed in more depth.

\section{The Language of Ecclesiastes}

In the past decade there has been renewed interest in the language of Ecclesiastes. Most recently, Seow has argued that linguistic considerations entirely preclude the possibility of dating the book later than the fourth century. For him, it is a product of the Persian period, specifically between the second half of the fifth century and the first half of the fourth. This conclusion is also defended by Seow on socioeconomic grounds. 11

Even supposing a Hellenistic dating for the composition of Ecclesiastes, the lack of grecisms in Qohelet's work should come as no surprise. In the book of Daniel, most certainly a product of the Hellenistic period, the use of Greek

9 D. Michel, Qohelet (Darmstadt:Wissenschaftliche Buchgesellschaft, 1988) 114; Whybray, Ecclesiastes, 11-12; J. L. Crenshaw, Ecclesiastes (Philadelphia: Westminster, 1987) 50.

10 H. W. Hertzberg, Der Prediger (KAT XVI, 4; Leipzig: Scholl,1932) 45-49. J. L. Kugel, "Qohelet and Money," CBQ 51 (1989) 46-49; C. L. Seow, "The Socioeconomic Context of 'The Preacher's Hermeneutic'," PSB NS 17 (1996) 168-95; "Linguistic Evidence and the Dating of Qohelet," JBL 115 (1996) 643-666.

11 Seow, "The Socioeconomic Context of 'The Preacher's' Hermeneutic," 171. 
loanwords is limited to the musical instruments played at the dedication of

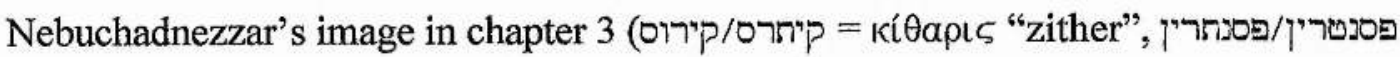

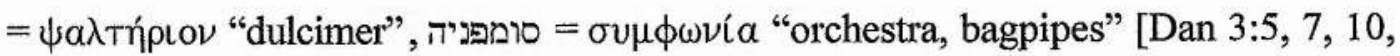
15]).12 The intent behind the use of these Greek words is specifically to introduce an "exotic" foreign element into the story of Daniel in a foreign court. 13 There are no grecisms in Daniel which might be construed as belonging to everyday speech. Nor do we find grecisms in Ben Sira or Hebrew texts from Qumran.

In contrast to the author(s) of Daniel, Qohelet does not seek to create an "exotic" foreign atmosphere in his work. That is not to deny the possibility of foreign influence on his thought, but the fact remains that Qohelet expressed himself in a language which would be accessible to the contemporary (Hebrew) reader. It uses a form of Hebrew which is probably colloquial: certainly the epilogue says that Qohelet "taught the people wisdom."14

Another important fact which should be noted is that Qohelet's use of Persianisms does not preclude a Hellenistic dating. The term פתגם, although of Persian origin, occurs in Dan 3:16;4:14. The use of the Persian loanword פרדם in the context of the Royal Experiment is evidence just as valid for a Hellenistic background to Ecclesiastes as a Persian. Indeed, if one considers this particular passage, the context appears to fit the Hellenistic era rather better: Crenshaw asserts that the series of first person verbs in this passage, "I built...", "I planted...", "I made...", is

12 F. Rosenthal, A Grammar of Biblical Aramaic (Wiesbaden: Harrassowitz, 1983) 59.

13 J. A. Montgomery (Daniel [ICC; Edinburgh: Clark, 1927] 201) remarks on the "cosmopolitan" nature of the musical instruments in Daniel compared with the Temple music as found in $1 \mathrm{Chr} 25: 1$; 2 Chr 5:12-13. N. Porteous (Daniel [OTL; London: SCM, 1979] 57-58) also calls attention to the "rhetorical effect" achieved by the repetition of the list of officials in 3:2, 3 (many of which are Persian loanwords: cf. Rosenthal, A Grammar of Biblical Aramaic, 58) and by the list of (largely Greek) musical instruments.

14 The point that Qohelet is using a form of colloquial Hebrew is made by Seow himself ("Linguistic Evidence for the Dating of Qohelet," 666) but was also previously suggested by Crenshaw (Ecclesiastes, 31). 
indicative of Qohelet's "personal involvement in a life of luxury at any expense",15 but it is clear that Qohelet is actually working very hard in this passage. In the space of five verses (2:4-9), there are eleven first person verbs, covering every aspect of managing an estate. Qohelet describes the material benefits which he enjoys as the just reward of hard work (2:-2:10).

Traditional interpretations of the "Royal Experiment" focus solely on the sensuality of the objects described in that passage: the fruit trees in specially watered orchards (2:5-6), the material wealth, livestock and servants which Qohelet accumulates (2:7-8).16 This is no pleasure dome however, but a thriving business. The Persian paridaida (par-te-taš) from which the Hebrew פרדס and the Greek

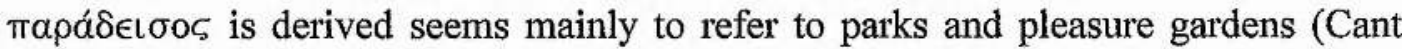
4:13 cf. AHW 833; LSJ 1308), but may also have a utilitarian function (Neh 2:8). The usage of the Greek derivation $\pi \alpha \rho a ́ \delta \in \iota \sigma o \varsigma$ in the Ptolemaic period as referring to an (economically productive) orchard, however, is also appropriate to the context of the "Royal Experiment." In the same context, an interesting parallel to Qohelet's usage in an apparently economic context of the terms כרמות , כימים "gardens" (2:5) and פרדסים "orchards" (2:5) occurs in Papyrus Petrie III 26: "If an ox, or beast of burden, or sheep or any other animal trespass on another man's arable

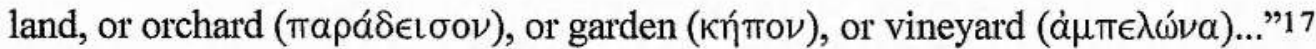

Seow's article on Qohelet's use of language will prove valuable in reopening the debate on the setting of Ecclesiastes, for he does much to show that Qohelet

15 Crenshaw, Ibid., 78.

16 e.g. A. Verheij, "Paradise Retried: On Qohelet 2:4-6," JSOT 50 (1991) 113-115; S. de Jong, "Qohelet and the Ambitious Spirit of the Ptolemaic Period," JSOT 61 (1994) 85-96. For a dating of the text to this period on very different (and almost certainly erroneous) grounds, cf. A. D. Corré, "A Reference to Epispasm in Koheleth," VT 4 (1954) 416-18.

17 H. L. Ginsberg (Studies in Koheleth [New York: Jewish Theological Seminary of America, 1950]

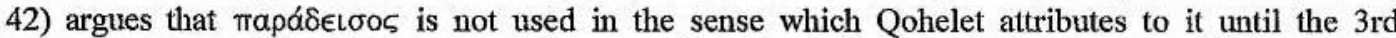
century B.C.E.. and that the same sense is not attributable to its usages in Cant 4:13 and Neh 2:8. 
might have written considerably earlier than the current consensus would suggest. By his own admission, however, almost all of the features of Qohelet's vocabulary and syntax are common to both the Persian and Hellenistic eras. The exception to this is Qohelet's use of של of the fifth to fourth centuries and it is on this basis that he dates Qohelet's work conclusively to the Persian period.18

As I demonstrate in a forthcoming article however, this conclusion is flawed. ${ }^{19}$ Evidence exists for a sustained usage of $\sqrt{ }$ in its technical legal/economic sense well into the Christian era. Since an investigation into Qohelet's use of this root forms the body of Chapter 4 of this thesis, a full discussion on its use for dating the book of Ecclesiastes will be found therein.

\section{Sociohistorical Evidence}

(a) Numismatic Evidence

In his article on the sociohistorical evidence for a dating of Ecclesiastes to the Persian period, Seow considers significant the fact that it was at this time that coins were introduced to Palestine. The "daric" began to be minted from around 515 B.C.E. onwards and coins of other denominations were minted in the provinces. In Seow's own words, "Coins began appearing [in Palestine] during the Achaemenian period, although they did not become common until the second half of the fifth century. And numerous hoards have been found at various sites in Israel, all dating to the fifth century and later."20

While it is true that the economy of the Persian Empire was to some extent

18 Seow, "Linguistic Evidence for the Dating of Ecclesiastes," 665-66.

19 Rudman, "A Note on the Dating of Ecclesiastes," CBQ 61 (1999) (forthcoming).

20 Seow, "The Socioeconomic Context of "The Preacher's' Hermeneutic," 171-73. Kugel also dates Ecclesiastes to the Persian period, partially on economic grounds ("Qohelet and Money," 46-49). 
based on the use of coinage, the economic documents which Seow adduces as evidence of this fact still show that many financial transactions at this time were still made in terms of goods or services. 21 If Qohelet's work can be said to reflect a thoroughly monetarized environment (5:9 [Eng. 10]; 7:12;10:19), then that environment would better fit the Hellenistic era. Where barter did not prevail in the Persian period, transactions commonly took place involving weights of silver rather than coinage per se.22 This must therefore cast doubt on whether money was utilised as widely as Seow would like to suggest. Hengel is certainly of the opinion that "by and large one might say that minted money was finally established in Palestine only through Ptolemy II, and largely superseded barter.23

A remarkable aspect of Palestine's archæology is that so far no Persian darics have been found. Such coins as occur (and these are relatively scarce compared with finds from the Hellenistic era) are very often Greek drachms.24 After 404 B.C.E., Persian governors minted their own copies of these coins. 25 Indeed, this state of affairs, in which Greek money was used either in preference to, or because of the scarcity of, the Persian daric in Palestine may be reflected in the appearance of a possible Greek loanword דרכמונים (= Gk. Gen. Pl. $\delta \rho \alpha \chi \mu \omega \hat{\omega} \nu)$ occurring in late (i.e. Persian period) texts such as Ezra 2:69; Neh 7:69-71.26 By way of contrast, the

21 Seow, Ibid., 172.

22 E. Stern, (Material Culture of the Land of the Bible in the Persian Period 538-332 B.C. [Warminster: Aris \& Phillips, 1982] 215) citing Arad Ostraca No. 41; F. M. Cross, "The Discovery of the Samaria Papyri," $B A 26$ (1963) 112. The earliest mention of coinage from Elephantine may be found in Papyrus 35, 11. 3-4 [400 B.C.E.] in A. Cowley, Aramaic Papyri of the 5th Century B.C. (Oxford: Clarendon, 1923) 130-31. Another text from Egypt dated 402 B.C.E. specifically mentions payment in "money of Greece" (E. G. Kraeling, The Brooklyn Museum Aramaic Papyri [New Haven: Yale University Press, 1953) 271.

23 M. Hengel, Judaism and Hellenism (London: SCM, 1974) 1.44, 2.34-35, 2.208-9.

24 K. Galling, Studien zur Geschichte Israels im persischen Zeitalter (Tübingen: Mohr, 1964) 101; Stern, Material Culture of the Land of the Bible in the Persian Period 538-332 B.C., 227.

25 Hengel, Judaism and Hellenism, 1.33.

26 Stern (Material Culture of the Land of the Bible in the Persian Period 538-332 B.C., 228) does not deny the existence of such a loanword, but argues that in these two contexts, the author meant to write אדרכונים "daric." 
Ptolemies were careful to maintain a strict coinage monopoly, with foreign coins being called in and reminted.27 In Palestine, finds of coins minted by Ptolemy II Philadelphus (283/2-246) exceed those minted by Ptolemy I Soter (323-283/2) by four-fivefold and of all other coins previously minted (Pre-Ptolemaic, Attic, Phoenician, Philisto-Arabian and those of Alexander) by eightfold.28 This evidence become still more impressive when one compares Philadelphus's reign of thirty-six years against almost two centuries of the "highly monetarized" Persian economy which Seow cites as evidence for a fifth-fourth century date for the composition of Ecclesiastes.

Thus, while a case can be made for a Persian background to Qohelet's interest in money and for the economically advanced society which is represented in Qohelet's work, a closer parallel may be found in the far more widespread use of coinage in Ptolemaic times, specifically under Ptolemy II Philadephus. Although Persian period documentation from Egypt and Mesopotamia indicates the growing importance of coinage in economic transactions, the physical evidence from archaeological finds does not support the thesis that its use was as widespread in Palestine at this time as Seow suggests. In contrast, finds from the Hellenistic era are extremely rich and are suggestive of an economic background much the same as that which is presupposed in Ecclesiastes.

\section{(b) Trade and Industry}

The question of whether the book of Ecclesiastes can be said to reflect any particular time in terms of the business atmosphere evoked by Qohelet's writing is a notoriously difficult one and a good case can be made by commentators arguing for a

27 Hengel, Judaism and Hellenism, 1.36.

28 lbid., 1.43-44. 
Persian or a Hellenistic background: both eras experienced times in which there were substantial increases in trade, resulting in prosperity for at least some of the inhabitants of Palestine. M. Dahood has even used Qohelet's interest in the world of business as evidence for a Phoenician origin to the work, 29 although his arguments for the same based on the language and orthography of the book have found little favour in more recent years. 30

As examples of the growth of trade in Persian times, Seow cites the population expansion which appears to have taken place in coastal areas, particularly Sharon, and archaeological evidence from Tell Dor, Tell Abu Hawam (Haifa) and Tell Shiqmona showing that these were centres of manufacture for textiles, purple-dye or for the storage of grain and wine. Inland, one finds evidence of foreign coins (unsurprising in view of the apparent scarcity of the daric in Palestine-see above), ceramics, precious metals and jewellery, glass and alabaster. This culture is, Seow argues, in line with the cosmopolitan Jerusalem described in Neh 13:15-16.31

Unfortunately, little information exists about agricultural innovations in Palestine during the Persian period, although it is known that the Persians made unsuccessful attempts to establish their native fruit trees (apricot, peach and cherry) in Asia Minor. 32 In the Jordan valley, the Persians apparently also established

29 M. Dahood, "Canaanite-Phoenician Influence in Qoheleth," Bib 33 (1952) 30-52, 191-221 (esp. 220-21 for commercial background); "Qoheleth and Recent Discoveries," Bib 39 (1958) 302-318; "Qoheleth and Northwest Semitic Philology," Bib 43 (1962) 349-365; Canaanite Words in Qoheleth 10,20," Bib 46 (1965) 210-212; "The Phoenician Background of Qoheleth," Bib 47 (1966) 264-282.

30 R. Gordis, "Was Koheleth a Phoenician? Some Observations on Methods in Research," JBL 71 (1955) 105-9; A. Schoors, "The Use of Vowel Letters in Qoheleth," UF 20 (1988) 277-86; J. R. Davila, "Qoheleth and Northern Hebrew," Maarav 5-6 (1990) 70-72.

31 Seow, "The Socioeconomic Context of 'The Preacher's' Hermeneutic," 174-75. The problem with Seow's picture of population expansion is precisely that such expansion took place on the coast (and not, apparently in the hill country). The building remains from the Persian period in Palestine are in fact remarkably scanty (Stern "The Archaeology of Persian Palestine," in W. D. Davies \& L. Finkelstein (eds.), The Cambridge History of Judaism Vol. 1: The Persian Period [Cambridge: C.U.P., 1984] 90-91).

32 H. Koester, History, Culture and Religion of the Hellenistic Age (Philadelphia: Fortress, 1984) 79. 
balsam plantations. These were relatively small at the time of Alexander (Pliny, Hist. Nat. 12.111-23) but were significantly extended as the Hellenistic period went on. ${ }^{33}$

Rapid and sustained development of trade and agriculture in Ptolemaic controlled areas occurred in the early Hellenistic era. For example, the trade in commodities such as precious metals, textiles, ceramics and glass was an important feature of business life at this time and underwent considerable expansion. ${ }^{34}$ The necessity of competing with the Seleucid power in the north meant that Ptolemaic Egypt became in the words of W. W. Tarn, "a money making machine."35 The state in effect was the property of the king who as a result of the various royal monopolies in trade and agriculture, became immensely rich (a situation which may well be reflected in the Royal Experiment in 1:12-2:12). 36

During the foundation years of the Ptolemaic period, particularly during the reign of Ptolemy II Philadelphus, Egypt and her provinces experienced an economic boom. Evidence for this assertion comes in part from the Zeno papyri, a series of

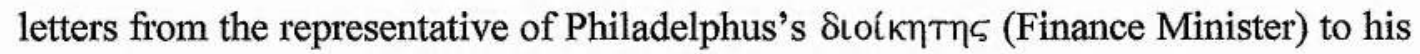
master reporting on the state of the king's possessions in Palestine. For example, Gaza is mentioned as an important centre for the trade of incense, myrrh, aromatic goods, spices and other luxury items. ${ }^{37}$ Papyrus was planted in Palestine in this

\footnotetext{
33 Hengel, Judaism and Hellenism, 1.45 .

34 Koester, History, Culture and Religion of the Hellenistic Age, 76-79.

35 W. W. Tarn \& G. T. Griffith, Hellenistic Civilization (3rd rev. edn.; London: Methuen, 1959) 179.

36 Hengel, Judaism and Hellenism, 1.35-36; C. Préaux, Le monde héllenistique: La Grèce et l'Orient de la mort d'Alexandre à la conquête romaine de la Grèce (232-146 av. J.-C.) (Paris, Nouvelle Clio, 1978) 208-12. In this context, see my forthcoming article "Qohelet's Use of לפני,", $J N S L$ 23/2 (1997), which argues that Qohelet's statement that he attained more wisdom or wealth "than all who were before me in Jerusalem" $(1: 16 ; 2: 7,9)$ refers to the king's ability to amass more wealth than his contemporaries: the expression היה לפני idiom meaning "to be subject to" (Cf. 1 Sam 29:7; 29:8).

37 V. Tcherikover, Hellenistic Civilization and the Jews (Philadelphia: Jewish Publication Society of America; Jerusalem: Magnes, 1959) 70.
} 
period.38 Grain and olive oil were important Palestinian exports and the slave trade also played a lively part in the local economy. ${ }^{39}$ Other goods, such as smoked fish, cheese, meat, dried figs, fruit, honey and dates, were also exported according to the Zeno archive (PCZ 59012-14). The cities of Jamnia and Ascalon were also founded or refounded at this time as a result of the Ptolemies' active sponsorship of urban building projects in Palestine (notably, such projects were not sponsored in Egypt itself, a circumstance which may suggest that Palestine remained comparatively underdeveloped during the Persian period). 40

While the archaeological evidence demonstrates an expanding Palestinian economy in Persian times, economic growth appears to have increased considerably under Ptolemaic rule. New agricultural settlements sprang up around Jaffa in the middle of the third century B.C.E. and a Hellenistic warehouse incorporating among other things an oil press, dyeing equipment and a workshop has been found in the same area. A dye-works was built at Tell Mor around this time and the importance of this industry to the local economy is confirmed by evidence of a wholesale wool dyeing business found in the Hellenistic strata of Gezer. This also implies the presence of sheep farming and weaving industries. 41

The Ptolemaic practice of planning the national economy is reflected by a range of technological innovations, such as improved oil and wine presses, the treadmill, the plough, and the introduction of new crops and improved breeds of livestock.42 One such technological advance is the introduction of the wheel for raising water: a technique previously unknown in Egypt and Syria-Palestine.

\footnotetext{
38 Hengel, Judaism and Hellenism, 1.46.

$39 \mathrm{Ibid}$., 1.41-42.

40 Koester, History, Culture and Religion of the Hellenistic Age, 209.

41 Hengel, Judaism and Hellenism, 1.46.

42 Ibid., 1.47.
} 
Artificial irrigation appears to have been unknown in Palestine before the Hellenistic period: it is notable that the first explicit mentions of such a practice occur in Ecclesiastes and Ben Sira (Eccl 2:6; Sir 24:30-31). While no archaeological evidence of such practices exist for Palestine in the Persian period, one finds at Adullam in Judea in the Hellenistic period artificial pools, terraces and canals much like those described by Qohelet in his "Royal Experiment" (Eccl 2:6).43

\section{(c) Society}

The book of Ecclesiastes tells us much about the nature of society when Qohelet was writing. It was apparently a time of frenetic commercial activity (2:4-9; $4: 4,8 ; 11: 1-2)$. But it was also a time when there was a great divide between rich and poor (5:11 [Eng. 12]). While the wealthy could afford to indulge themselves in the luxuries which Qohelet recommends, the poor suffered under heavy burdens and corruption was rife $(3: 16 ; 4: 1)$. Nor was there much hope for the individual, apparently, in going to law. Justice could be, and seemingly was, denied to those who were lower down on the social scale (5:7 [Eng. 8]).

Kugel and Seow have both pointed out that this situation is or may be to some extent applicable to Palestinian society during the period of Persian domination. ${ }^{44}$ To be sure, most of Seow's examples of parallels to the situation as described in the text of Ecclesiastes come from Egypt and Mesopotamia. However, parallels exist with the situation in Judah as described in the book of Nehemiah in which people were forced to take out loans against their property to buy food during a famine or to pay taxes (Neh 5:3-4) or even giving their children as pledges for debt $(5: 5) .45$ This was not an unusual situation, for Nehemiah goes on to remark on the

\footnotetext{
$43 \mathrm{Ibid}, 1.46$.

44 Kugel, "Qohelet and Money," 35-37, 46-48; Seow, "The Socioeconomic Context of "The Preacher's' Hermeneutic," 182-85.

45 Seow, Ibid., 185; Hengel, Judaism and Hellenism, 1.49.
} 
heavy taxes exacted by former governors from the general populace $(5: 15)$.

On the other hand, the situation which we find in the Hellenistic period is also one in which these conditions occurred. Whereas very little is known for sure about the socioeconomic situation in Palestine during the later Persian period to which Ecclesiastes has been dated by Kugel and Seow, the situation during the Hellenistic period, as well as being inferred from Egyptian documents of the time, is described in Palestine by the Zeno archive. In a letter to Zeno, one of his Palestinian employees complains that his wages are unpaid by his Greek masters on a regular basis because "I am a barbarian...and am not able to speak Greek (öTı oùk

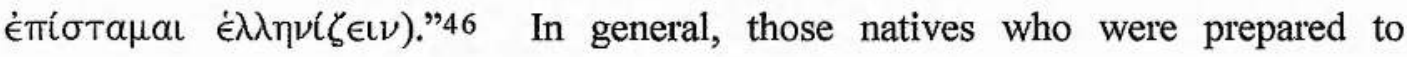
"hellenize" by learning to speak Greek fared much better than the non-Greek speaking "barbarians" who were ruthlessly exploited by the Greek upper classes. 47

Just as in the period of Persian domination, defaulting debtors in the Hellenistic era could be sold into slavery. 48 The Ptolemaic system which steered the economy also had a more insidious influence on society however. As we have seen, it could bring spectacular benefits for some (notably Greeks or Hellenized natives), but denied ordinary people a share in the benefits of the economic growth which took place in the third century B.C.E.. In the words of Koester: "The primary cause [of social injustice and unrest] can...be found in the system of state monopoly, which continuously confronted the native working class with oppressive rules and regulations, but never granted a share in the proceeds of their labor and in the general wealth of the country."49 Such a scenario for society during the Ptolemaic period gives added irony to Qohelet's words "What profit is there for a man in all his labour

$\overline{46 \text { PColZen 2,16ff., no. 66, 18, } 21}$ cited by Hengel, Ibid., 1.39, 2.31.

47 Ibid., 1.38.

48 Ibid., $1.49,57$.

49 Koester, History, Culture and Religion of the Hellenistic Age, 55; Tcherikover, Hellenistic Civilization and the Jews, 72. 
which he undertakes under the sun?" (Eccl 1:3, cf. 3:9). The double entendre behind Qohelet's recurrent use of ענה ("to occupy", "to afflict") in such statements as "I have seen the business/affliction which God has given humanity to be occupied/afflicted with" (1) 3:10 cf. $1: 13 ; 2: 23,26 ; 4: 8 ; 5: 2$ [Eng. 5:3]; 8:16) may well reflect this social setting and draw an implicit parallel between the actions of the oppressive Greek employers of the day and a deity who demands no less work of his subjects.

\section{Thought}

No author's work can be said to be entirely original. All are to some extent dependent for their worldview on their cultural background and history. Indeed, Qohelet himself might be said to concur with such a view in his statement "that which has been is that which will be, that which has been done is that which will be done: there is nothing new under the sun" (1:9).

Most commentators agree, however, that Qohelet's thought is at times very different from anything which we find elsewhere in the Hebrew Bible. 50 Indeed, this fact was recognised at a very early stage. In Midrash Rabbah, we read: "The sages sought to suppress the book of Qohelet because they found in it words of heresy" (Midr. Qoh. to $1: 3 ; 11: 9) .51$ This naturally gives rise to the question of what precisely is the cultural backgound that gave rise to Qohelet's work.

\section{(a) Ancient Near East}

\section{(i) Mesopotamia}

Similarities between Mesopotamian thought and that of Qohelet have in the

50 Michel, Untersuchungen zur Eigenart des Buches Qohelet (BZAW 183; Berlin: de Gruyter, 1989) 289; H.-P. Müller, Neige der althebräische 'Weisheit': Zum Denken Qohäläts," ZAW 90 (1978) 23864; Crenshaw, Ecclesiastes, 52; Whybray, Ecclesiastes, 23.

51 R. B. Salters, The Book of Ecclesiastes: Studies in the Versions and the History of Exegesis (Ph.D. Diss.; St. Andrews, 1973) 3. 
past been noted. This is particularly true in the case of the Epic of Gilgamesh, and almost all commentaries make an overt comparison between Eccl 9:7-10 and the speech of Siduri the barmaid to Gilgamesh in the Old Babylonian version of this saga (Tablet $\mathrm{x}$, iii $[A N E T, 90]) .52$ Affinities have also been noted with other Mesopotamian texts such as the ludlul bel némeqi("I Will Praise the Lord of Wisdom" 2.10-38 [ANET, 434-35]) which states that divine decrees are hidden from human sight (cf. $3: 11 ; 8: 17$ ) and that righteous and wicked may receive the same treatment from the gods (cf. 8:12-14). This view is also to be seen in "A Dialogue about Human Misery" (27.276-80 [ANET, 438-40]). At the same time, humanity's evils are stated to be against the will of the gods ([VIII] 11. 79-86, ANET, 439) and firmly rooted in human perversity. The essential problem is that the gods are remote and interfere in human life only in the most general ways ([VII-VIII] 70-77; [XXIII] 11. 243-44; [XXIV] 11. 255-64, ANET, 439-40). If some aspects of this text may be termed fatalistic, it is certainly not as thoroughgoing as in the work of Qohelet. Another oft cited parallel occurs in the "Pessimistic Dialogue between Master and Servant" (VIII 11. 55-60, ANET, 438) which adopts an ambivalent attitude towards women, similar in some respects to that of Qohelet.53 Qohelet's apparently contradictory attitude towards women $(7: 26 ; 9: 9)$ will form the subject of Chapter 6 of this thesis.

Among more recent commentators, $\mathrm{O}$. Loretz has argued forcefully for a Semitic background to the thought of Qohelet. For him, the parallels with Mesopotamian literature, although not enough to prove direct dependence, point to a

\footnotetext{
52 For a detailed treatment, see J. de Savignac ("La sagesse du Qôhéléth et l'épopée de Gilgamesh," VT 28 [1978] 318-323). Cf. e.g., Hertzberg, Der Prediger, 158-59; A. Lauha, Kohelet (BKAT 19; Neukirchen-Vluyn: Neukirchener, 1978) 169-70; Crenshaw, Ecclesiastes, 162; Whybray, Ecclesiastes, 143. The caution of Ranston (Ecclesiastes and the Early Greek Wisdom Literature [London: Epworth, 1925] 146) in asserting Qohelet's dependence on this work is, as Whybray remarks, justified.

53 Crenshaw, Ecclesiastes, 51-52; Murphy, Ecclesiastes (WBC 23A; Dallas: Word, 1992) xlii-xliii.
} 
shared worldview (Loretz is particularly impressed by the parallels between Eccl 9:7-9 and the Epic of Gilgamesh). 54 It would be surprising if this were not the case, however. The question is, can a Semitic background account convincingly for all of Qohelet's thought?

\section{(ii) Egypt}

Parallels also exist between the book of Ecclesiastes and Egyptian thought. This need not in itself be surprising, since Israelite wisdom was to some extent influenced by Egyptian ideas. For example, the dependence of Prov 22:17-24:22 on the Egyptian "Instruction of Amenemope" remains generally accepted, although some scholars have recently cast doubt on this hypothesis. 55

With regard to the book of Ecclesiastes itself, the situation is altogether less clear. Comparisons have been made to such texts as the "Instruction of "Onchsheshonqy" (AEL 3:184-217, 159-84) and the "Dialogue between a Man and his Soul" (11. 65-68, ANET, 405) with their injunction to enjoy life's material benefits in the face of uncertainty or death (cf. Eccl 9:7-10; 11:7-12:7).56 Others have argued that Ecclesiastes is a "Royal Testament" in the vein of the teaching of Merikare $(A N E T, 414-18), 57$ although Qohelet apparently drops his royal persona after 2:12. The idea of dependence per se between Egyptian wisdom and the work of Qohelet has in fact never gained general acceptance, and though the works discussed in this section are frequently cited in commentaries, this is largely to demonstrate that

54 O. Loretz, Qohelet und der Alte Orient: Untersuchungen zu Stil und theologischer Thematik des Buches Qohelet (Freiburg: Herder, 1964) 45-134.

55 Whybray, The Composition of the Book of Proverbs (JSOTSup 168; Sheffield: JSOT, 1994) $132 \mathrm{ff}$. Discussions on the influence of Egyptian thought on the wisdom of Israel may be found in W. McKane, Proverbs (OTL; London: SCM, 1970) 51-208; R. J. Williams, "The Sages of Ancient Egypt in the Light of Recent Scholarship," JAOS 101 (1981) 1-19.

56 B. Gemser, "The Instructions of "Onchsheshonqy and Biblical Wisdom Literature." in Congress Volume, Oxford, 1959 (VTSup 7; Leiden: Brill, 1960) 102-28.

57 K. Galling, Der Prediger (HAT 18; Tübingen: Mohr, 1969) 88; G. von Rad, Wisdom in Israel (OTL; London: SCM, 1972) 226-237. 
thinkers in different cultures considering similar questions ("how much control do we have over our own fate?", "how should we approach death?") tend to reach similar conclusions. 58

\section{(b) Greece}

The question of whether Qohelet shows traces of Greek thought refuses to go away. H. Ranston argued that Qohelet is dependent on early Greek philosophy, particularly the work of Theognis. 59 Comparisons have also been made with Heraclitus (fl. 500 B.C.E.), whose philosophy exerted considerable influence on Stoic thought.60 Others have sought parallels with the main philosophies of the Hellenistic era (notably Stoicism and Epicureanism). 61

The most thorough treatment of the question of possible Greek influence on Qohelet's work has been provided by R. Braun.62 According to Braun, Qohelet was indeed influenced directly by his Hellenistic environment in his choice of terms and

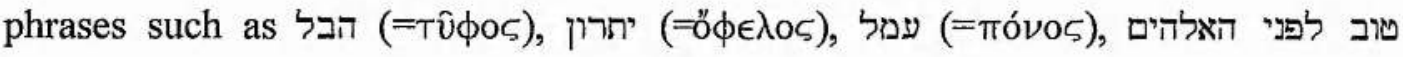

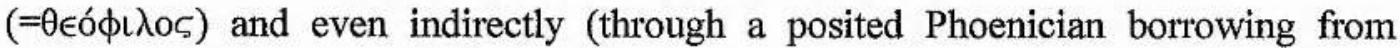

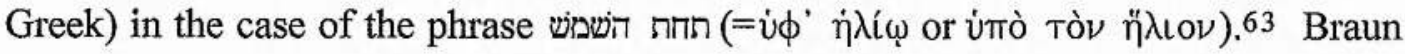
also considers more general questions such as the style in which Greek philosophical thought was presented (e.g. the diatribe, an idea later put to use by Lohfink in his

$\overline{58 \text { Crenshaw, Ecclesiastes, 51-52. }}$

59 Ranston, Ecclesiastes and the Early Greek Wisdom Literature, 13-62. M. Strange argues strongly against this position, however (The Question of Moderation in Eccl 7:15-18 [S.T.D. Diss; Catholic University of America, 1969] 115-120.

60 E. Pfleiderer, Die Philosophie des Heraklit von Ephesus, nebst Koheleth und besonders im Buch der Weisheit (Berlin: Reimer,1886).

61 T. Tyler, Ecclesiastes (London: Williams \& Norgate, 1874) 10-29; E. H. Plumptre, Ecclesiastes (Cambridge: C.U.P., 1881) 30-32; E. Bickerman, Four Strange Books of the Bible (New York: Schoken, 1967) 141-49; J. G. Gammie, "Stoicism and Anti-Stoicism in Qoheleth," HAR 9 (1985) 169-87; J. Blenkinsopp, "Ecclesiastes 3.1-15: Another Interpretation," JSOT 66 (1995) 58-59, 62.

62 R. Braun, Kohelet und die frühhellenistische Popularphilosophie (BZAW 130; Berlin: de Gruyter, 1973).

63 Ibid., 44-55. 
commentary) and philosophical concerns common to the general stock of Greek thought and that of the author of Ecclesiastes.64 Braun's work has not won full acceptance, but it nevertheless still enjoys some measure of support from more recent commentators. 65

Since the appearance of Braun's work, Lohfink has also appeared as a champion of the theory of widespread borrowing from Greek thought in the work of Qohelet. Lohfink's dating of Ecclesiastes to the period 190-180 B.C.E. is almost a necessary concomitant to his belief in heavy and diverse Greek influence on the work. In Lohfink's view, Ecclesiastes was written as a response to a religious crisis provoked by the Pro-Hellenist element in the upper classes and was designed to combine the best elements of Greek philosophy and Judaic religious belief.66

Parallels for this intention certainly exist: Aristobulus, writing in the midsecond century, attempted to write a commentary on the Pentateuch in the light of Stoic philosophy, and Philo of Alexandria also attempted to combine Greek (primarily Platonic but to a lesser extent Stoic) and Jewish thought in a series of works. 67 However, there are real problems with Lohfink's position.

First of all, Lohfink dates the book (deliberately) to a time of social tension. Syria-Palestine had recently been racked by wars between the Ptolemies and the Seleucids, having been temporarily overrun in 219 B.C.E. by Antiochus III and finally coming under Seleucid control in 195 B.C.E., only five years before the proposed date

64 See $\mathrm{n} .71$ below.

65 O. Kaiser, "Judentum und Hellenismus," VF 27 (1982) 69-73; M. V. Fox (Qohelet and his Contradictions [JSOTSup 71; Sheffield: Almond, 1989] 16) states: "Although many of the parallels Braun adduces are not persuasive, he has undoubtedly made the case that Qohelet was not isolated from his contemporary intellectual context."

66 Lohfink, Kohelet (Würzburg: Echter, 1980) 7-15. The book is dated to the late second century on slightly different grounds by F. Hitzig (Der Prediger Salomo's [KHAT; Leipzig: Weidmann, 1847) $122-24$.

67 Koester, History, Culture and Religion of the Hellenistic Age, 144; T. H. Tobin, "Logos," in $A B D 4.350$. 
of Qohelet's work. Yet Ecclesiastes says nothing of the economic upheavals which must have accompanied these invasions. The socioeconomic setting presupposed by Ecclesiastes is one of peace in which individuals may acquire considerable fortunes through business $(2: 4-11 ; 4: 7-8 ; 5: 9-10$ [Eng. 11-12]). Fortunes are lost as well as made (5:12-14 [Eng 5:13-15]; 11:1-2), but this is the result of unlucky speculation rather than the devastation of war.

Secondly, Lohfink perhaps goes too far in imagining an elaborate background for Qohelet and his work. For example, he suggests that Qohelet belonged to an important priestly family and that the Jerusalem Temple was used as an educational establishment in an attempt to counter the growing influence of Greek schools. One of the "set texts" for study was what we now know as the book of Ecclesiastes. ${ }^{68}$ In many ways, Lohfink's reconstruction is not unlike the rather fanciful "ideal" biography of Qohelet built up by Plumptre. 69 The book of Ecclesiastes contains very little hard evidence about the author. The fact that respectable commentators can differ so profoundly about its setting illustrates that only the most general conclusions can safely be reached on the question of Qohelet the man.

The difficulties with Lohfink's dating of Ecclesiastes lead us back to the third century B.C.E.. This was, as we have seen, a time of peace and of economic expansion commensurate with the background presupposed by Qohelet's work. It is at this point that an examination of the possibility of influence from the main Greek or Hellenistic philosophies of that period is appropriate.

\section{(i) Epicurean Philosophy}

Many other commentators have argued for the influence of Greek philosophy on Qohelet's work. Tyler accounted for the contradictions apparent in the book of

68 Lohfink, Kohelet, 8.

69 Plumptre, Ecclesiastes, 35-55. 
Ecclesiastes by suggesting that Qohelet combined elements of Stoicism and Epicureanism in his work. In doing so, Qohelet sought to argue against them and so reassert the traditional Judaic faith. 70 Again, this is a position not unlike that of Lohfink who posits that the contradictions in Ecclesiastes can be resolved by understanding the book as a diatribe. ${ }^{71}$ However, Podechard is correct in pointing out the problems with Tyler's theory of Epicurean influence on the work of Qohelet.72 Tyler argues that Qohelet's recommendation to joy is in line with Epicurean belief and specifically links Eccl 5:18-20 with the concept of $\dot{\alpha} T \alpha \rho a \xi i \alpha$ or tranquillity which should be the goal of the Epicurean sage. 73 A closer inspection of Epicurean thought, however, shows that where Qohelet considered that the best that could be expected of joy would be that it might enable the individual to largely forget the supreme injustice of death (5:19 [Eng. 20]), the Epicureans faced death squarely and without qualms: "death is nothing to us" (Epicurus, Letter to Menoeceus, 124;

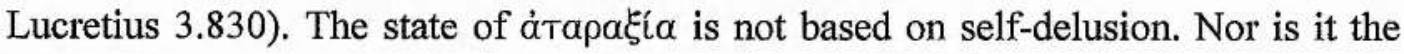
experience of what Epicurus would call "kinetic" pleasure (cf. Qohelet's recommendation to "eat and drink" in $2: 24 ; 3: 13 ; 5: 17 ; 8: 15)$. Rather, it denotes the complete absence of fear or pain (Epicurus, Letter to Menoeceus 127-32). ${ }^{74}$ The serene attitude to life and its vicissitudes which the Epicueans counselled is in fact utterly alien to Qohelet.

\section{(ii) Cyrenaic Philosophy}

Although a thorough investigation falls outside the bound of this thesis, a

\footnotetext{
$\overline{70 \text { Tyler, Ecclesiastes, 10-29, } 33 .}$
}

71 Lohfink, Kohelet, 10, following Braun, Kohelet und die frühhellenistische Popularphilosophie, 36, 165, 179 and S. de Ausejo, "El género literario del Ecclesiastés," EstBíb 7 (1948) 394-406.

72 E. Podechard, L'Ecclésiaste (Paris: Lecoffre, 1912) 95-102.

73 Tyler, Ecclesiastes, 20.

74 A. A. Long \& D. N. Sedley, The Hellenistic Philosophers (Cambridge: C.U.P., 1987) 1.121-25. 
much closer parallel to Qohelet's exhortations to joy exists in the philosophy of the Cyrenaics. This school was active in the reign of Ptolemy II Philadelphus (283/2246), and took its name from the province of Egypt where it originated. Their main tenets were that life was unknowable and unjust and that the correct human response was consequently to seek what happiness was attainable through material pleasure.75 In this, they differed significantly from the Epicureans (DL 10.136). They also advocated suicide as a legitimate response to the inequities of existence, in line with the statement of Theognis, "Of all things to men on earth, it is best not to be born...or, once born, to pass as quickly as possible through the gates of Hades" (Theognis 425-7, cf. Eccl 4:3). Cyrenaic philosophy quickly became one of the main philosophies of Ptolemaic Egypt in the time of Philadelphus and eventually had to be suppressed because of a sharp increase in the suicide rate. 76

Unfortunately, we have little information about the Cyrenaics other than that derived from fragmentary quotations and reports. We cannot know whether Qohelet was directly influenced by this philosophy. However, the Cyrenaics no doubt contributed to and were a reflection of the Hellenistic Zeitgeist of the third century B.C.E.. If the generally accepted dating of Ecclesiastes to the mid-third century or not long after is correct, we should not be surprised at the affinities between the thought of Qohelet and the philosophy which had created such a stir elsewhere in the kingdom of Philadelphus.

(iii) Stoic Philosophy

The area of possible Greek influence on the work of Qohelet which has

75 H. D. Rankin, Sophists, Socratics and Cynics (Beckenham: Croom Helm, 1983) 200-201; W. K. C. Guthrie, History of Greek Philosophy Vol. 3 (Cambridge: C.U.P., 1969) 493-94. For texts, see E. Mannebach, Aristippi et Cyrenaicorum Fragmenta (Leiden: Brill, 1961) 36, 40-41, 43-44 (fr. $145,156-57,161,181-83)$.

76 Mannebach, Aristippi et Cyrenaicorum Fragmenta, 57 (fr 247a-b). 
elicited most discussion is its relationship to the thought of the Stoics. The conclusions of Tyler as far as Stoic influence on Ecclesiastes was concerned were quickly accepted by Plumptre, Siegfried and Condamin, 77 However, doubts as to this theory surfaced early and Delitzsch and McNeile contended that everything in Ecclesiastes could be accounted a natural development of Semitic thought. 78 Barton also concurred with this view, claiming that such parallels as exist between Ecclesiastes and Greek philosophy prove "...at most that Qohelet was a Jew who had in him the makings of a Greek philosopher."79

In more recent times, Gammie and Blenkinsopp have also advanced the hypothesis of some form of Stoic influence on the author of Ecclesiastes. 80 Gammie's methodology is superior to that of many of his predecessors in that he largely limits his discussion to known Stoic belief of the third century B.C.E.. $81 \mathrm{He}$ attempts to resolve the discrepancies between Qohelet's thought and that of the early Stoic leaders by arguing that Qohelet accepts some Stoic ideas and argues against others. Similarly, Blenkinsopp suggests that the catalogue of times in 3:2-8 was produced by a Stoicizing Jewish sage, being quoted by Qohelet in order to argue against it. 82 Although the consensus remains that Qohelet was active in the third quarter of the third century B.C.E., the idea of Stoic influence on the book of Ecclesiastes has gained no firm acceptance.

Perhaps the most striking feature of Stoic philosophy is that it advances the

77 Plumptre, Ecclesiastes, 30-32; C. G. Siegfried, "Review of T. Tyler, Ecclesiastes," ZWT (1875) 284-291, "Der jüdische Hellenismus," ZWT (1875) 469-489; Prediger und Hoheslied (HAT II, 3/2; Göttingen: Vandenhoeck \& Ruprecht, 1898) 8-10; A. Condamin, "Etudes sur 1'Ecclésiaste," $R B 9$ (1900) 30-44.

78 F. Delitzsch, Ecclesiastes, 210; E. Renan, L'Ecclésiaste, 62-63; A. H. McNeile, An Introduction to Ecclesiastes, 43-44.

79 G. A. Barton, partially quoting McNeile above (Ecclesiastes, 34).

80 Gammie, "Stoicism and Anti-Stoicism in Qoheleth," 169-87; Blenkinsopp, "Ecclesiastes 3:1-15: Another Interpretation," 55-64.

81 Gammie, Ibid., 173.

82 Blenkinsopp, "Ecclesiastes 3.1-15: Another Interpretation," 61. 
concept of a highly developed form of determinism. This is the belief that everything in the cosmos is controlled by a single force, which may be termed "God" or "Fate."83 The consequences of such a belief as far as humanity is concerned is that the individual is not responsible for his/her own thoughts and actions. This has important moral repercussions when it comes to the question of human evil: should individuals be punished for their own wickedness, or should blame be allotted to the deity who controls their actions? This was a problem which preoccupied the second and third leaders of the Stoic school, Cleanthes and Chrysippus and their solution was to limit the influence of determinism over human actions (although the approach of each was fundamentally different). 84

This problem was also current in Judaism around 180 B.C.E. when Sirach was writing. Apparently, the wicked could justify their actions at the time by making an appeal to a highly developed and logical form of determinism which had gained some ground in Jewish thought at that time:

Do not say, "The Lord is to blame for my failure"; it is for you to avoid doing what he hates.

Do not say, "It was he who led me astray"; he has no use for sinful men.

The Lord hates every kind of vice; you cannot love it and still fear him.

When he made man in the beginning, he left him free to take his own decisions;

if you choose, you can keep the commandments; whether or not you keep faith is yours to decide.

He has set before you fire and water; reach out and take which you choose; before men lie life and death, and whichever he prefers is his. For in his great and mighty power the Lord sees everything.

He keeps watch over those who fear him; no human act escapes his notice.

83 R. Taylor, "Determinism," in Encyclopedia of Philosophy (London \& New York: Macmillan, 1967) 2.359 .

84 W. C. Greene, Moira: Fate, Good and Evil in Greek Thought (Cambridge: Harvard University, 1944) $344-50$. 
But he has commanded no man to be wicked, nor has he given licence to commit $\sin$.

(Sir 15:11-20, NEB Translation)

The precise relationship between Ben Sira and Ecclesiastes remains unclear, but the passage above may suggest that some parts of Stoic deterministic theory exerted an influence over Judaic thought before the Greek domination over Palestine came to an end. On the other hand, evidence also exists for a deterministic worldview in biblical texts which may date from a time prior to the Hellenistic period (Exod 7:2-3; Pss $31: 15 ; 139: 16)$. Under these circumstances, the explanation offered by the sinner for his actions in this passage from Ben Sira may be seen as being in line with purely Judaic thought.

Many commentators have argued that Qohelet himself was a determinist. 85 No full agreement exists on the nature of this determinism, nor whether any aspects of this determinism can be shown to come from a source in Stoic philosophy, as opposed to a Hebraic source. The object of this thesis is therefore twofold: firstly, it aims to show that Qohelet was indeed a determinist. It will also consider questions such as the problem of human evil and how Qohelet explains this in the light of his deterministic belief. A natural corollary of this will be an investigation into the extent to which Qohelet regards the human will as being free to make choices and how this is combined with the concept of determinism. Finally, having built up a picture of Qohelet's worldview, this will be compared with determinism as it is expressed elsewhere in the Hebrew Bible, early Jewish texts, and with Stoic beliefs of the third century B.C.E. in order to discover the probable source(s) of Qohelet's thought.

85 Delitzsch, Ecclesiastes,254-55; Ginsberg, Studies in Koheleth, 37-38; R. B. Y. Scott, Proverbs Ecclesiastes (AB18; Garden City: Doubleday, 1965) 221; Fox, Qohelet and his Contradictions, 192; Murphy, Ecclesiastes, 33. 


\section{Chapter 2 \\ Qohelet and Fate}

\section{Introduction}

Was Qohelet a determinist? Many commentators have suggested as much. Delitzsch, for example, despite dating Ecclesiastes to the Persian period, nevertheless saw key texts expressing Qohelet's worldview such as Eccl 3:1-15; 9:11-12 as deterministic, stating that "(Man) is on the whole not master of his own life."1 More recently, Fox has argued in much the same vein. 2 Other commentators more wary of committing themselves on this question have nevertheless hinted that at least some aspects of Qohelet's work may be explicable from a deterministic angle. Thus, Crenshaw states: "If we cannot determine our future, however much we try, God's disposition towards us becomes a matter of life and death...The inevitable consequence of such thinking would seem to be some form of determinism." 3

Some commentators such as Podechard have argued that determinism is not evident at all in Ecclesiastes. Many passages presuppose a certain amount of free will on the part of humanity.4 Indeed, Qohelet regularly uses the imperative form of the verb which implies that the reader has a choice of whether or not to follow Qohelet's advice (4:17 [Eng. 5:1]; 5:1 [Eng. 2]; 3 [Eng. 4]; 5-7 [Eng. 6-8]; 7:9-10, 13$14,16-17,21,27 ; 8: 2-3 ; 9: 7-10 ; 10: 4,20 ; 11: 1-2,6,9-12: 1)$. These are powerful arguments against understanding Qohelet as a determinist, so the fact that so many commentators continue to see evidence of determinism in his work may appear surprising.

\footnotetext{
1 Delitzsch, Ecclesiastes, 254-5; 365-7.

2 Fox, Qohelet and his Contradictions, 192.

3 Crenshaw, Old Testament Wisdom (Atlanta: John Knox, 1981) 136. Whybray's position on the concept of "giff" in Ecclesiastes is similar: "God may give joy and pleasure; man can never achieve it for himself, however hard he may try." ("Qoheleth, Preacher of Joy," JSOT 23 [1982] 89).

4 Podechard, L'Ecclésiaste, 192.
} 
At a fundamental level, determinism and free will are incompatible concepts. Nevertheless, philosophers who we call determinist have tried to combine them. For example, Chrysippus, the third leader of the Stoic school, argued powerfully for the influence of determinism on all earthly events (Cf. e.g. SVF 2.997). Nevertheless, when confronted by the dilemma of whether this meant that human beings were not morally responsible for their own actions, he also found a place for a limited degree of human free will in his worldview (e.g. SVF 2.1000). The same might also be said of his predecessor Cleanthes (e.g. SVF $1.537 ; 2.993$ ). The Stoicism of the 3rd century B.C.E. therefore advanced a form of "soft determinism" (the belief that humanity's actions are guided by a combination of predestination and free will), as opposed to "hard determinism" (the belief that all human action is preordained and that free will is therefore an illusion).

In the Hebrew Bible itself, there also exists a tradition of determinism, as Von Rad has pointed out. 5 However, what is noticeable about biblical determinism when compared to later beliefs, is that it is more concerned with expressing the idea of divine sovereignty over history than of pursuing the logic of its own thought to explain the relationship between the individual and the world. Instead, it is content to reaffirm traditional Hebraic thought in this regard. Thus, Von Rad states: "...even when the use of the term 'determinism' is justified, it is never a question of a complex of ideas that have been thought through philosophically and logically. Thus, for example, the individual's freedom of decision in religious and ethical matters is, strangely enough, scarcely affected."6

It is possible therefore that Qohelet is advancing a form of soft determinism in line either with biblical or Stoic thought. Such an idea cannot be ruled out on the

5 Von Rad, Wisdom in Israel, 263-283.

6 Ibid., 263. 
basis of Qohelet's apparent belief in human free will elsewhere. However, only a full investigation of the relevant passages and key terms said to be deterministic can tell us more about Qohelet's worldview. This chapter will therefore be concerned with exploring Qohelet's use of such key terms in contexts where determinism might be implied.

\section{Key Terms in Ecclesiastes}

$$
\text { 1. קרה / מקרה }
$$

The noun מקרה occurs 7 times in Ecclesiastes $(2: 14,15 ; 3: 19$ [3x]; 9:2,3), and its associated verb 3 times $(2: 14,15 ; 9: 11)$. Elsewhere in the Hebrew Bible, these terms appear to have a neutral sense: in Ruth 2:3, the noun מקרה describes the happy accident of Ruth gleaning in the field of Boaz. In 1 Sam 6:9 it is used to distinguish between divine retribution and ordinary misfortune. In 1 Sam 20:26 it refers simply to a chance occurrence. All 19 usages of the verb קרז in the Hebrew Bible appear to carry this sense of "chance" happening (cf. BDB 899-900). In Ecclesiastes however, קרזה occurs almost exclusively in the context of death (the only exception being 9:11 in which it denotes the occurrence of ill-fortune). This section will therefore investigate Qohelet's understanding of this term against the backdrop of its usage elsewhere in the Hebrew Bible.

(a) The Versions

(i) The Septuagint

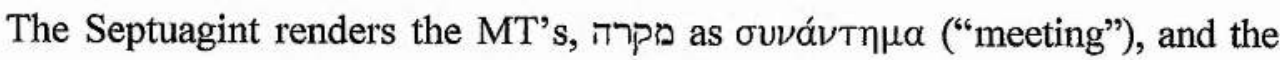

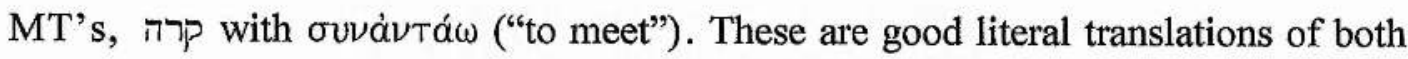
Hebrew terms, although they do little to explain the meaning of קרה as Qohelet uses it. Some commentators have posited that the term מקרה in Ecclesiastes is a grecism 
which translates the term $\sigma u \mu \phi o p \eta$. For example, Podechard cites Plumptre as

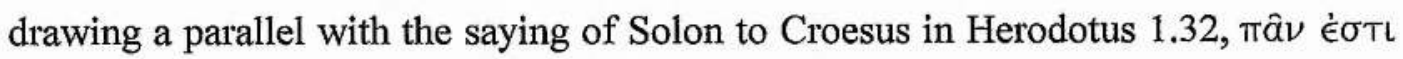

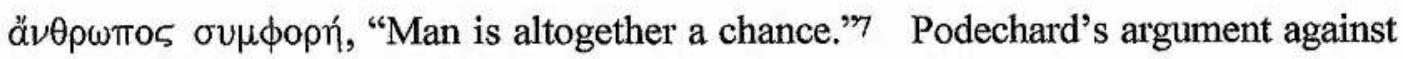
this is probably correct, however. The quotation from Herodotus suggests that one's life and the opportunities or obstacles which present themselves are subject to no external force, but are random. The fact that some events in human life are subject to chance is, however, also the idea behind the usage of מקרה in 1 Sam 6:9;20:26. If the term מקרה in Ecclesiastes were to mean "chance event", then it would demonstrate a connection with Hebraic, rather than Greek, thought.

\section{(ii) The Vulgate}

The observation of Crenshaw that the term מקרה is primarily bound up with the concept of death 8 is well illustrated by the Vulgate, which translates it three times with the noun interitus "death" (2:14; 3:19 [translating מקרה twice]), once with occasus "downfall, death" (2:15), once with the more neutral conditio (3:19), although the occurrence of interitus immediately preceding gives it a negative meaning. In 9:2, 3 for the remaining occurrences of the term מקרה, the Vulgate uses a circumlocution involving the verb evenio "to happen, befall." The interpretation of the term מקרה therefore has a strongly negative slant which is conditioned by the context in which Qohelet uses it rather than by the meaning which $V_{\text {in }}$ has in the rest of the Hebrew Bible.

\section{(iii) The Targum}

The Targum translates the MT's מקרעון/אירעון with ("happening",

\footnotetext{
7 Podechard, L'Ecclésiaste, 50. Plumptre (Ecclesiastes, 135) remarks concerning Qohelet's use of מקרה in 3:19 and the saying in Herodotus 1.32: "(here) we have an echo, almost a direct translation, of a Greek saying."

8 Crenshaw, Ecclesiastes, 85.
} 
"event") and the MT's ערע/ארע with "to happen" in all locations. Predictably, the Targum goes its own way with its interpretations of the relevant verses, but these nevertheless offer some insight into the Targumist's understanding of Qohelet's use of קרהת.

In $2: 14$, the Targum speaks of the role which the sage plays in mitigating divine judgement on a sinful world by offering his prayers to God. The result of a failure to do so is that "punishment comes upon the world, one thing will befall all of them" (ייתי פורענותא בעלמא אירעון חד יארע ית כולהון). Subsequent to this, in 2:15 Qohelet/Solomon goes on to remark, "According to the fate of Saul...also such will befall me" (כארעון שאול...כדין יערעני). In this case, the term מקרה is perceived not as referring to death, but to the stripping of the kingdom from Saul as a consequence of disobedience and $\sin$.

In 3:19, the Targum modifies the bleakness of Qohelet's assertion by stating, "For what happens to guilty people and what happens to the unclean beast is the same for all of them" (ארום ארעון אנשא חייבא וארעון בעירא מסאבא ארעון חד לכולהון). Here the MT's מקרז is understood as referring to death. The same, however, cannot be said of the Targumic interpretation of 9:2, 3. In 9:2, the Targum renders Qohelet's thought deterministically: "All depends upon Fate, and from Heaven it is decreed what will happen. The same thing befalls everyone, the innocent and the guilty" (ולחייבא כולא במזליא תליא מן שמיא אתגזר מה דעתיד למהוי לכולא אירעון חד לזכאה). This is echoed in the succeeding verse (9:3) in which the Targum states, "There is an evil Fate (lit: 'planet') in all the world in all that is done under the sun, for one thing befalls everyone; all the inhabitants of the earth" (לכל דיירי עלמאדין מזל ביש בכל עלמא) (דייתעביד תחות שמשא ארום ארעון חד לכולא . The precise nature of this evil fate is uncertain, although the Targum in this verse implies that it may be connected with 
judgement after death.

Thus, there is a common theme in the Targum's interpretation of passages in which the term מקרה occurs. It denotes the intervention of the deity in some form. This may be punishment as a consequence of sin, or it may refer to the divinely ordained time of one's death. The use of the term "Fate" in these passages to explain the term is indicative of a deterministic reading by the Targumist, for מז ultimately refers to one's destiny as it appears in the stars. Despite Rabbinic injunctions against such practices, astrology features very heavily in the Targum of Qohelet, as will be demonstrated later in this chapter.9

The Targumist's use of the term in these locations perhaps suggests that he considered there to be a link between the terms עת מקרה ("appointed time" $[3: 2 ; 7: 17])$ as referring to death, and that he was cognizant also of the corresponding implications for Qohelet's worldview, namely that there was an outside agency at work in the determination of one's moment of death and that correspondingly, the term מקרה should not retain the meaning of "chance event" which it has elsewhere in the Hebrew Bible.

\section{(iv) The Peshitta}

The Peshitta translates the noun מקרה in all locations with the term r.t. and the verb קוth we equivalent_..2. This Syriac root has the basic meaning "to happen, befall" and is, for example, used in the Peshitta of Gen 42:29; Josh 2:23 in a neutral sense. Some ambiguity must be said to exist, however, since the noun may also have the sense of "chance occurrence" and is used to translate when it is used in this sense elsewhere in the Hebrew Bible (e.g. 1 Sam 20:26). In effect then, the question is left open as to whether the Peshitta understands $\sqrt{ }_{\text {in }}$ in Ecclesiastes

9 P. S. Knobel, The Targums of Job, Proverbs, Qohelet (Edinburgh: Clark, 1991) 29. 
as referring to chance occurrence or just to "that which happens."

\section{(b) Mediæval Jewish Exegesis}

The interpretations of the Vulgate and Targum are reflected in Mediæval Jewish exegesis of the relevant passages. Rashi on $2: 14,15$ sees the term as ultimately referring to death to which all must succumb, whether wise or foolish. Thus on 2:14 he states: "Also, I, who praise the wise man over the fool, know that they both will die" (גים אני [ידעתי] אשר משבח את החכם מן הכסיל יודע אני ששניהם ימותו), whilst on $2: 15$, he comments: "Since they will both die, perhaps I will think in my heart from now on that what happens to the wicked man will also happen to me" (לפי שששיהם ימותו שמא אהרהר בלבי מעתה כמקרה הרשע גם אני יקרני). Notably, Rashi here extends the reference of מקרה from death to include what happens to the individual during his life. Rashi's comment on מקרה אחד 9:2 makes it clear that he understands it as referring to death: "And they know that the end of everyone - righteous or wicked - is to die, and they all have one fate in this world ...but there is a difference between them in the world to come" ויודעים שסוף הכל) (אשר צדייק ואשר רשע למות ומקרה אחד יש בעולם הזה...שיש הפרשש ביניהם לעולם הבא Rashi goes further in his exegesis of other passages however, and gives some idea of what he considers to be the meaning of the term מקרה.

Thus, on 3:19 Rashi remarks: "This is the reason for the matter, that the Holy One, blessed be He, gave a fate and a mishap (lit: "meeting") to humankind and there is a fate and a mishap to the beasts, and He gave one fate to both of them, for just as this one dies, so does that one" (הוא טעם הדבר אשר נתן הקב"ה מקרה ופגע לבני אדם ויש מקרה ופגע לבהמה ומקרה אחד לשניה נתן. כי כשם שזה מת כך זה מת . While Rashi sees the term מקר a bound up with death in this verse also, he also makes it parallel to the term פגע which also occurs in Ecclesiastes (9:11) in a passage sometimes seen 
as betraying deterministic overtones. As shall be demonstrated in the next section, in which the noun פגע is considered, this term in the Hebrew Bible refers to some form of encounter, but to one which is planned or co-ordinated. Thus, it refers not to a "mischance" as such, but to an event which is determined by some agency.

Rashbam follows the general interpretation understanding מקרה as referring to death in 2:14: "I shall die just as one of the fools..." (שאמות כאחד מן הכסילים). However, he too expands on what he understands to be the meaning of elsewhere in his commentary. Thus, he explains the term מקרה 3:19 by the use of the term מנדג "rule": "for what happens to humankind and what happens to beasts is the same. There is one rule, that both die in the same way" (שהרי מקרה האדם ומקרה (הבהמה מקרה אחד. ומנהג אחד הוא שמתים שמיהם בעניניין אדד The use of a term such as again suggests an ordering principle which governs death. Here Rashbam most likely implies that death is an ordinance imposed by God. Such an interpretation is in line with Qohelet's own words in 3:18. The use of $\sqrt{2}_{2}$ is also prominent in Rashbam's interpretation of 9:2: “every misfortune is directed and designated to come upon them, and the same thing befalls them all" (כל רעות גהוגות ומזומנות) (לבוא עליהם ומקרה אחד לכולם certainly deterministic: the events which befall the individual cannot be attributed to chance but to a co-ordinating outside force. Death (מקרה) is but one manifestation of this force.

Like Rashi and Rashbam, Metzudath David also understands מקרה 2:14 as a reference to death: "I know that there is one fate, the fate of death: behold it befalls them all, be they wise man or fool" (ידעתי שמקרה אחד הוא מקרה רמיתה הנה יקרה את) (כולם החכם יהיה או סכל Likewise in his interpretation of 3:19, he remarks: "There is one fate that is common to both, namely that just as this one dies, so does that one 
die" (ויש מקרה אחד לשניהם כי כאשר ימות זה כן ימות זה 9:2, he expounds on Qohelet's thought in a similar vein, "Everything comes to them as it comes to all. He (Qohelet) proceeds to explain: there is a common fate for the righteous and the wicked" (הכל יבוא להם כמו שיבוא לכל והוזר ומפרש מקרה אחר לצדיק ולרשע). Notably, Metzudath David's choice of the term מיתה to explain מקרה 2:14 may be suggestive that he too understands the term to be indicative of something more than "chance", since this term is most often used in a legalistic sense: i.e., it typically (although not exclusively) means "death penalty" rather than "death."10

In fact, Mediæval Jewish commentaries are almost unanimous in their adoption of this position. Sforno is unique in the interpretation which he places on 9:2, in which he understands מקרה as referring to divine assistance granted to human beings: "The divine aid given to the wicked, the unclean and the sinner for their deeds, is the same as that which is given to the righteous for the deed of the wise man." (הסיוע האלהי באלה לרשע ולטמא ולחוטא בפעולתם כמו שהיה לצדיק בפעולת החכם). Even though he differs so fundamentally from his fellow exegetes as to offer a positive meaning for the term מקרה, he too understands it as something more than simple chance.

Thus, the position of the Mediæval Jewish commentators, with the exception of Sforno, on the meaning of the term מקרה seems to be that it refers specifically to death. In this, they follow in the tradition of some versions, particularly the Vulgate and Targum. The closeness of some of the Mediæval Jewish exegetes to the position of the Targumist in particular, that death is not a product of chance, is suggested by

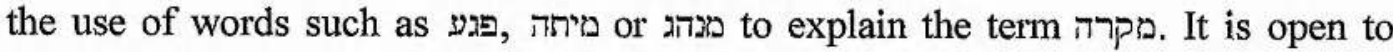
question whether these terms refer to the general rule that all die, or whether they

10 M. Jastrow, A Dictionary of the Targumim, the Talmud Babli and Yerushalmi, and the Midrashic Literature (New York: Judaica, 1992) 780. 
allow for the determination of a specific time of death for every individual. However, Qohelet's use of the term עת "appointed time" in passages referring to death $(3: 2$; 7:17) certainly does suggest that the time of one's death is effectively in the hands of an outside agency, as shall be demonstrated presently.

\section{(c) Modern Commentators}

The conclusion of the Vulgate, Targum and the majority of Mediæval Jewish commentators that the term מקרה refers to death is reflected in the positions of many modern commentators. Thus, Crenshaw argues concerning poth the noun...and the verb...have an ominous nuance everywhere in Ecclesiastes with the possible exception of 9:11 which emphasises the unpredictability of events." 11 Nevertheless, the tendency in recent times is not to see the term מקרה as indicative of a belief in determinism on Qohelet's part. Fox describes מקרה as "fate' in the sense of what happens to someone, as opposed to what he does to himself (not in the sense of what is predetermined)." 12 Fox is certainly correct in his assertion that מקרה is "what happens to someone" (i.e., that it refers to events outside human control). However, although the term מקרה may not have the explicit sense that an event is predetermined, this does not preclude its referring to such an event.

In the final analysis, קרה as it is used in Ecclesiastes cannot refer to a chance occurrence. The fact of death is not a matter of chance: it is the one event which is guaranteed to come to all. Nor is the timing of one's death down to chance, for as we have seen, Qohelet uses the term ע ("appointed time") of death $(3: 2 ; 7: 17)$. While Qohelet is disturbed by death, he recognises that it is an evil to which all must submit $(8: 8 ; 9: 2-3,10)$. Qohelet's main concern with death in fact seems to be the unpredictability of death's timing $(7: 15 ; 8: 14)$.

11 Crenshaw, Ecclesiastes, 85.

12 Fox, Qohelet and his Contradictions, 184. 
This element of unpredictability is not incompatible with the idea that one's time of death is determined by God. Indeed, it is this very circumstance which is the source of the crisis in Qohelet's thought, for there is no apparent causal connection between one's religion or morality and the length of one's allotted span. Indeed, it may even be that the intent behind Qohelet's use of the term מקרה is not that death is a "chance" occurrence, but that the time at which it occurs is an unpredictable one. Certainly this element of unpredictability is behind the use of the verbal form p' in 9:11, and since it is said generally by Qohelet in the verse following that "Man does not know his appointed time...(it) falls suddenly on them" (9:12), the same might also be applied to the "appointed time" of death. From the idea of "chance happening" to "unpredictable happening" there is not a great semantic shift, and though Qohelet may observe in 3:18-21 that both humankind and animals suffer death, it is impossible to say for certain when this will happen and what happens to the soul afterwards. The only predictable thing about death for Qohelet is that it will occur.

\section{(d) Conclusion}

This study has sought to demonstrate that Qohelet's usage of diverges to some extent from its biblical background. Elsewhere in the Hebrew Bible, Vin has the sense of "chance happening", "event." In Ecclesiastes however, it is used almost exclusively of death: the single event which is absolutely certain to come to all. Qohelet cannot mean by his use of the term מקרה the time at which one dies is a matter of chance, since his use of the word עת ("appointed time") in the context of death $(3: 2 ; 7: 17 \mathrm{cf} .12: 7$ for God as the giver and taker of the life-breath) implies that there is a fixed time for this occurrence, as indeed there is for all things (3:1-8, $17 ; 8: 8)$. 
The idea that מקרה does not have this sense of "chance occurrence" in Ecclesiastes is supported at least to some extent by the Versions. Both the LXX and the Targum translate with neutral terms meaning simply "happening", "event", as indeed does the Vulgate in 9:2, 3. Even the Peshitta's rendering r.z又 is to some extent ambiguous.

From the actual interpretations offered by the Targum and the Mediæval Jewish commentators of passages in which $\sqrt{ }$ pappears, it is clear that there was a general consensus that Qohelet's usage of this root was not indicative of a belief in chance as a governing force in life. Such interpretations as are offered, if they are not explicitly deterministic, often imply the role of God in determining the moment of death.

Although one cannot go so far as to say that Qohelet's usage of קרה of itself indicates a belief in some kind of Fate governing existence, it certainly serves to underline a certain passivity in human life: human beings may attempt to "do", but ultimately their lives are defined by things that "happen." Qohelet's use of the term מקרה therefore serves to underline the unpredictability of the time of death, the fact that it is outside human control (cf. 8:8), without the implication that it is a matter of chance, for Qohelet's understanding of death elsewhere highlights the role of the deity in determining the moment of its occurrence. 
2. פגע

The noun the Hebrew Bible (1 Kgs 5:18 [Eng. 5:4]). In $1 \mathrm{Kgs} \mathrm{5:18,} \mathrm{it} \mathrm{refers} \mathrm{to} \mathrm{a} \mathrm{misfortune} \mathrm{(the}$ occurrence or not of which is evidently determined by God), although there it is modified by the adjective 2.13 In the Hebrew Bible, the verbal form can mean "encounter (with evil intent)" or "harm" (Josh 2:16; Judg 8:21), but it may also have the more neutral basic meaning of "meet" (1 Sam 10:5; Gen 32:2). In MH, M. Jastrow emphasises the connotations of misfortune that פגע often carries. ${ }^{14}$ In Eccl 9:11, the term פגנ is typically translated "chance" in English Bible translations.

The Hebrew text under consideration here reads: שבתי וראה תחת השמש כי לא לקלים חימרוץ ולא לגבורים המלחמה וגם לא לחכמים לחם וגם לא לנבנם עשר וגם לא לידעים הן (So I turned and I saw under the sun that the race is not to the swift, nor the battle to the strong, nor yet bread to the wise, nor yet riches to those with understanding, nor yet favour to the skilful, but time and 'meeting' happen to them all").

In view of the discussion which has just centred on the meaning of מקרה in Ecclesiastes (i.e. that it means "[unpredictable] happening" rather than "chance happening"), it is significant that Qohelet uses the verbal form יקרה in this verse to describe how "time and meeting" manifest themselves in human life. This suggests in turn that the noun does not refer to the influence of chance over human endeavour. In order to put this to the test, the meaning of the latter will now be investigated.

\section{(a) The Versions}

13 Fox (Qohelet and his Contradictions, 261) remarks that in this particular instance, it is impossible to determine whether ער is a necessary modifier to this term, or merely juxtaposed with פג for emphasis.

14 Jastrow, Dictionary, 1135. 


\section{(i) The Septuagint}

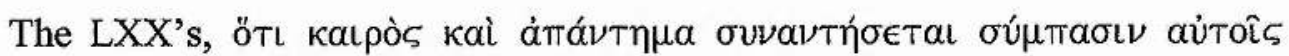
("for time and meeting befall all of them") remains close to the literal meaning of the Hebrew, particularly with the use of ámá $\nu T \eta \mu \alpha$ ("meeting") to translate the Hebrew פגע. It does not, however, immediately clarify Qohelet's understanding of the term.

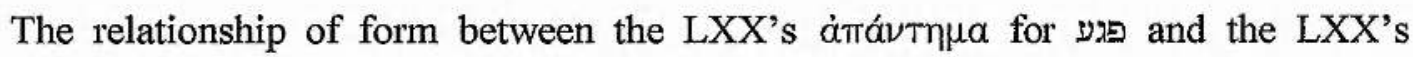

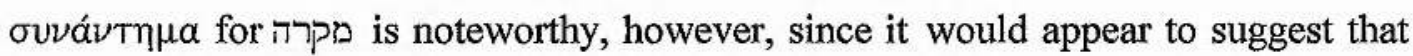
the LXX translator saw the two concepts as interrelated. At any rate, the occurrence

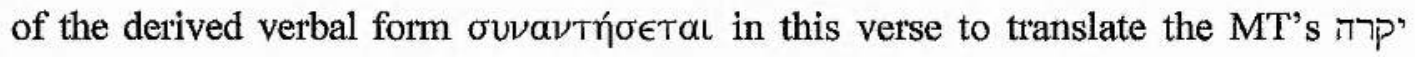
suggests that this may have influenced the choice of a related noun to translate the subject of the verb.

\section{(ii) The Vulgate}

The Vulgate's sed tempus casumque in omnibus, is to some extent ambiguous, since the noun casus can mean either "accident", "event", "occurrence" or "mishap." Its semantic range does not, however, coincide with the idea of "meeting" in the Hebrew פרפ attempt to interpret the difficult Hebrew פגע rather than translate it. As far as the Versions are concerned, this translation is the odd one out since it appears to suggest explicitly an element of randomness in events (Cf. the use of the ablative form casu, "by chance" in Latin). Although a poor rendering, it does at least attempt to make sense of the Hebrew. As such, it appears to have influenced all English translations (e.g. Gen. B, AV, RV, RSV, NRSV, NEB, REB: "time and chance").

(iii) The Targum

The Targum's, ארום עידן וערעיתא במזליהון יערע ית כלהון ("but time and 
meeting happen to all of them according to their Fate") illustrates an early deterministic reading of this verse, and emphasises that the Targumist understood the ערעיתא as referring to more than mere random occurrence. The term עת ופגע phrase translates the MT's 꼽, and is translated "chance" in Jastrow, (although its only citation is for Tg. Qoh. 9:11). However, like the Hebrew verb פָָּ the Aramaic verb ערע he sense of "to happen", "to meet." "Chance" is a misleading translation in this particular context, since a thing which happens according to the planets is not random but preordained. In many ways, it is worth bearing the idea of "meeting" in mind which is evident in both the Hebrew and Aramaic versions, and which also underlies Qohelet's use of the terms מקרה/קרה in Ecclesiastes.

\section{(iv) The Peshitta}

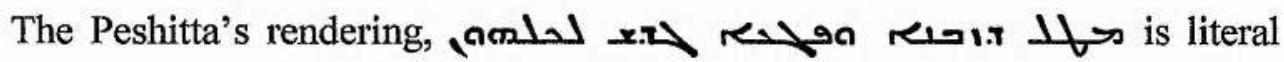
and makes use of the Syriac cognate term פענ this term has very much the same semantic range as its Hebrew equivalent (i.e. "meet", "befall", "happen"), and in fact is regularly used to translate $\sqrt{ }$ פy by the Peshitta.15 Thus, it sheds no further light on the meaning of the term in Eccl 9:10.

Although no definite pronouncements can be made on the basis of the evidence thus far adduced as to whether Qohelet's view of the world is deterministic, or whether he sees existence as altogether more random in nature, it is noteworthy that the Targum consistently carries forward a deterministic interpretation of Ecclesiastes. This in turn is frequently followed by the Mediæval Jewish exegetes.

\section{(b) Mediæval Jewish Exegesis}

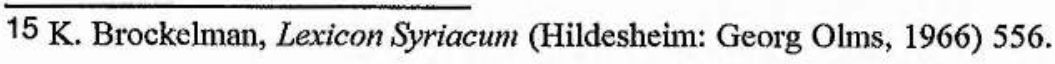


The work of the Mediæval Jewish exegetes may also cast some light on Qohelet's intent here. Rashbam appears to follow the deterministic reading of Targum when he states: עת ופגע ומקרה "קרה להם "the appointed time, meeting and event befalls them..." Japhet and Salters translate מקרה here as "fate." 16 This is a nuance which is not made explicit in Ecclesiastes, where the root refers only some form of (unpredictable) happening. Nevertheless, their interpretation of Rashbam's underlying intent is probably correct, since in his comment on 3:19-20 as we have seen, he interprets Qohelet's מקרה as a מבה or "rule"17 (Cf. the statement in Abodah Zarah 54b: עולם במנהגו נהוג "the world (nature) follows its own law"), thereby implying God's role in determining the ultimate end of his creatures.

Ibn Ezra's interpretation is more explicitly deterministic and is essentially derived from that of the Targum: פירוש פגע פגיעת אחד מן המערכת באחד מהשבכעה (The meaning of פנע is the meeting of one of the arrangement [of stars] with one of the seven [aspects]"). This understanding is underlined by Gómez Aranda's comment on Ibn Ezra's exegetical technique: "Ibn Ezra makes a play on words: פגיעת signifies 'the meeting of the stars' which influences the fortune (עפ) clearly sees the hand of Fate at work in the events which Qohelet describes and פגע is כמשממעו "as its apparent meaning" is not helpful for our purposes.

Thus, at least some of the Mediæval Jewish commentators saw the workings of Fate rather than chance behind the events and circumstances which Qohelet describes in the Book of Ecclesiastes. This deterministic interpretative tradition, as shall be demonstrated in due course, comes even further to the fore in the attempts of

\footnotetext{
16 S. Japhet \& R. B. Salters, Rashbam on Qohelet (Jerusalem: Magnes, 1985) 182-83. 17 Ibid., 120-21.

18 M. Gómez Aranda, El Comentario de Abraham Ibn Ezra al Libro del Eclesiastés (TECC 56; Madrid: CSIC, 1994) 147.
} 
Targum and some mediæval exegetes to explain Qohelet's use of the term ע ("appointed time").

\section{(c) Modern Commentators}

The alternative interpretative tradition represented by the Vulgate, that refers to a "chance occurrence" continues in the thought of most modern commentators. Thus, Crenshaw states: "Chance governs human lives, according to Qohelet...No one can prepare for the unexpected or compensate for randomness."19 Such a reading of 9:11 is also reflected in the various translations offered for the term פגי by others: "Zufall" (Zimmerli, Lohfink), "Glück" (Hertzberg), "Bad luck" (Scott). ${ }^{20}$ Glasser refers to the "accidents" (in the sense of chance happenings) which govern life, as does Seow.21 Whitley is in a minority in his suggestion that while may refer to a "mischance" elsewhere, here it has the neutral sense of "event" or "happening."22

As Fox points out, even if פנע in Eccl 9:11 is semantically neutral, the occurrences which Qohelet describes therein are examples of misfortune. ${ }^{23}$ The term פגע denotes something which prevents the strong from victory in war and the swift from winning the race. In other words, it deprives those with a peculiar talent from experiencing the just reward of that talent. Taken in isolation, these two examples might suggest single, isolated incidences of bad luck, yet Qohelet goes on to say that the wise may not be able to earn their living, nor the intelligent riches, nor the skilful gain favour because of עת ופגע. These latter examples are indicative of more than a

19 Crenshaw, Ecclesiastes, 164.

20 Zimmerli, Der Prediger (ATD 16/1; Göttingen: Vandenlıoek \& Ruprecht, 1962) 223; Lohfink, Kohelet, 71; Hertzberg, Der Prediger, 160; Scott, Proverbs Ecclesiastes, 245.

21 E. Glasser, Le procès du bonheur par Qohelet (Paris: Cerf, 1970) 157; Seow, Ecclesiastes (AB 18C; Garden City: Doubleday, 1997) 308.

22 C. F. Whitley, Koheleth: His Language and Thought (BZAW 148; Berlin \& New York: de Gruyter, 1979) 80.

23 Fox, Qohelet and his Contradictions, 260-61. 
single piece of misfortune affecting the outcome of an action. They illustrate illfortune dogging entire lives, perhaps even the whole of existence. 24

Murphy follows Ginsberg in seeing here a reference to death.25 Murphy argues that 'No matter what one's talents, because of events beyond human control, one never has a sure grip on success. The 'time of calamity' is an unfortunate time, a fortuitous event that happens when one cannot cope with it. It refers to death, but also to any serious adversity." Although Murphy's interpretation of the verse as referring to death creates contextual problems, it is interesting to note that he focusses on the fact of the outcome of one's efforts being ultimately "subject to events beyond human control." 26 If such events which determine the outcome of one's efforts are not coordinated, then they may be denoted by the term "chance." If they are coordinated in some way, then the outcome of one's actions are subject to Fate.

In this context, it is particularly striking that in none of the examples for the noun or the verb occurrence or meeting. In the case of Josh 2:16 and Judg 8:21 there is intent behind both uses of the verb: Josh 2:16 speaks of pursuers meeting their prey and Judg 8:21 of Gideon "meeting", or falling on Zebah and Zalmunna following their challenge, with the intent of killing them. In those examples of a more neutral meaning for the verb, we see God's angels meeting Jacob in the wilderness in Gen 32:2 and the prophecy of Samuel in 1 Sam 10:5 that the spirit of God will come upon Saul when

24 E. Glasser, Le procès du bonheur par Qohelet, 152.

25 H. L. Ginsberg (Qoheleth [Jerusalem 7 Tel Aviv: Newman, 1961] 116) argues that עמ ופנע refers specifically to the time of death in Eccl 9:11. This assertion is influenced by the appearance of עת רעה in v. 12, a passage which is frequently interpreted thus. In this he follows Barton (Ecclesiastes, 164) and ultimately Metzudath David. Whilst the thought which he sees in 9:11 is not alien to Qohelet, it does not explain why those with a peculiar talent do not enjoy the reward thereof in life. Ginsberg's position is also adopted by Barucq (Ecclésiaste [Paris: Beauchesne, 1968] 163) and Murphy (Ecclesiastes, 94).

26 Murphy, Ibid., 93-94. 
he meets a company of prophets. Neither of these meetings can be said to be chance: on the contrary, they are intended by at least one of the parties involved. Even the single usage of the noun in $1 \mathrm{Kgs} \mathrm{5:18} \mathrm{(Eng.} \mathrm{5:4)} \mathrm{is,} \mathrm{as} \mathrm{I} \mathrm{have} \mathrm{argued,} \mathrm{reflective} \mathrm{of} \mathrm{the}$ same: the non-appearance of a פג ע to trouble Solomon's reign is attributed to God.

\section{(d) Conclusion}

In conclusion then, the evidence gathered in this section supports the hypothesis that the term פוע Eccl 9:11 is not to be understood as implying that events in human life are subject to chance. Despite the interpretative translation of the Vulgate (founded apparently on little more than guesswork), which appears to understand chance as the controlling force in existence, the Targum and some Mediæval exegetes bear witness to the existence of a tradition in which the verse was understood in quite the opposite sense; namely that human life was largely subject to a deterministic force. Qohelet's use of פעע in conjunction with the term עת ("appointed time") is significant, for it implies that coordinated. This conclusion is in fact close to that of Whybray, who remarks, "pega', like miqreh...does not mean 'chance' in an impersonal sense, but simply what happens. What will happen, and when it will happen, are beyond human ability to foresee."27

This conclusion finds further support from a consideration of the contexts in which פגטע is used elsewhere in the Hebrew Bible. Whether used in the sense of "attack" or "meet", the action denoted by $\sqrt{ }$ is always the product of intent. The implication for Eccl 9:11 is similarly that the inexplicable adversities in life which beset human endeavour are the product not of life's randomness but of its orderliness.

27 Whybray, Ecclesiastes, 146. 


\section{3. עת}

The importance of the term עת to Qohelet's worldview may be seen in the fact that it occurs 40 times in Ecclesiastes (3:1, 2 [x4], 3 [x4], 4 [x4], 5 [x4], 6 [x4], 7 [x4], 8 [x4], 11, 17; 7:17; 8:5, 6, 9; 9:8, 11, 12 [x2]; 10:17). We have seen examples of how the term is used in conjunction with פגע מקרה in contexts where some form of divine intervention in human affairs is being asserted by Qohelet. The object of this section will be to explore how Qohelet uses this term in isolation.

Since 30 of the 40 occurrences of the term עת occur in the passage 3:1-11, the investigation of this text will form a large part of this section. Thereafter, its usage will be considered in $7: 17 ; 8: 9 ; 9: 8 ; 9: 12 ; 10: 17$.

\section{$\underline{3: 1-11}$}

30 out of 40 occurrences of the noun עת appear in the passage 3:1-11. This passage is therefore crucial for our understanding of what Qohelet means when he speaks of ("time"). The views of modern commentators on the passage vary. Some see in 3:1-11 a deterministic worldview expounded by Qohelet: others an unrealised and unrealisable ideal of acting at the appropriate moment which was so much a part of Israelite Wisdom.

$3: 2-8$ is essentially a list of opposite or near-opposite actions which may occur in the course of a human lifetime. Although this section does have a degree of importance for our study, and will be commented upon in due course, it will not immediately yield the thought behind the term עת as used by Qohelet. This investigation will therefore focus initially on 3:1 and 3:11.

\section{(a) The Versions}

Both זמן and are unusual terms, and may be indicative of the relatively 
late Hebrew of Qohelet. זמן "time", "appointed time" (so BDB 273-74) occurs elsewhere in the Hebrew Bible only in Neh 2:6; Est 9:27, 31. All of these occurrences have the idea of an appointed time for some event. In Neh 2:6, Nehemiah tells the King at what time he will return from his visit to Jerusalem. In Est 9:27, 31, the appointed times for Jewish festivals are described. ץøח in the sense of "business", "matter", "thing", may also be a late usage, occurring three times outside Ecclesiastes (Isa 58:3, 13; Prov 31:13) and three times in Ecclesiastes (Eccl 3:1; 5:7; 8:6). In Isa $58: 3$ the context is of furthering one's affairs by fasting, in Isa 58:13 it is used of business which breaks the sabbath, and in Prov 31:13 of the business which the diligent wife pursues.

The structure of 3:1 suggests that זמן מל לכל חפץ and parallel in meaning. Thus עת for Qohelet would have the meaning of "appointed time." This is also suggested by the LXX which translates עת with кaìos in $3: 2,3,4,5,6,7,8$, 11, yet in 3:1 uses xpóvos for the MT's עת and kaipos for the MT's זמן. The Vulgate's tempus is also used to translate the MT's in 3:1, whilst in 3:2, 3,4,5,6, 7, 8, 11 it translates the MT's עת. In 3:1, the Vulgate translates the MT's עת with the noun spatium ("period of time"). The Targum meanwhile, uses the equivalent Aramaic terms for "appointed time": זמנא for the MT's עידנא for the MT's 5.. It thus affords little help from a lexical perspective in interpreting this passage. The Peshitta's וכת is is used twice to translate both the MT's זמן in $3: 1$. Thus, the Versions unanimously support the conclusion that עמ זמן mean the same thing, i.e. "appointed time."

By whom are these times appointed? All commentators, whether they argue that the catalogue of times is an expression of the wisdom ideal of attempting to act at the appropriate moment, or whether they understand it in a deterministic sense, 
understand the times of 3:1-8 as appointed by God.28 This is also the position of the Targumist, who once again understands $3: 1-11$ as advocating a deterministic worldview. The occurrence of the term מזל in the Targum's rendering of 3:9, "What advantage is there to a working man...unless he is helped by Fate from above?" gives yet another indication of the grip which deterministic thinking held over the Aramaic translator of Ecclesiastes.

As shall be seen presently, the term which occurs in the Targum with some frequency in a deterministic context, also appears in the work of several Mediæval Jewish exegetes. On this subject, E. Levine remarks:

On fifteen occasions the targum utilises the term MAZAL which $\mathrm{I}$, with serious reservations, have translated as 'Providence'...In post biblical Judaism it is a most problematic concept. In the targum, God determines mazal (Cf. V, 18; VI, 2; X, 6) and good mazal is a reward given to deserving people $(\mathrm{V}, 17)$. On the other hand, mazal is used to describe inescapable fate: a person can do nothing to change his mazal (IX, 11). Due to its mechanistic and deterministic features, the targum uses it to account for such inequities as the suffering of the righteous and the well being of the wicked (VIII, 15). The mazal elements in the targum testify that PharisaicRabbinic tradition did not eradicate the grip of astrology on the popular mind, even in cases where mazal triumphed over zekut, i.e. accrued merit, "Everything is determined by mazal!" (IX, 2). Yet here too on occasion the targum tempers this fatalism by explaining that God determines even what the mazal will bring (IX, 12). Finally, the targum includes a stern warning against the study and practice of astrology (XI, 4), although it is itself contaminated by it.29

This fatalistic understanding of existence also underlies the Targumist's interpretation of 3:11 in which Solomon prophesies concerning Jeroboam and the

\footnotetext{
28 Siegfried, Der Prediger, 39-41; M. Devine, Ecclesiastes or the Confessions of an Adventurous Soul (London: Macmillan, 1916) 56; Glasser, Le proces du bonheur par Qohelet, 61; D. Kidner, A Time to Mourn, and a Time to Dance [Leicester: Inter-Varsity,1976] 38-39; Whybray, Ecclesiastes, 73; Seow, Ecclesiastes, 171.

29 E. Levine, The Aramaic Version of Qohelet (New York: Hermon, 1978) 75-76, cited by Knobel, The Targums of Job, Proverbs, Qohelet, 29.
} 
division of the kingdom: "The Lord made everything beautiful in its time: for the quarrel which happened in the time of Jeroboam son of Nebat was fitting to happen in the days of Sheba son of Bichri but it was delayed and happened in the days of Jeroboam son of Nebat for if it had happened in the days of Sheba son of Bichri, the Temple would not have been built" (ית כולא עבד "י" שפר בעידניה דחזיא דהות מצותא דהות ביומי ירכשם בר נבט למהוי ביומי שבע בר בכרי ואתעכבת והואת ביוכי ירבעם בר נבט דאילו הות ביומי שבע בר בכרי לא הות מתבני בית מוקדשא . Thus, the Targumist again understands the phrase יפה בעתו as illustrative of Qohelet's deterministic worldview. The actions which human beings perform occur at the time set by God and are thus "beautiful" from God's perspective, playing a part in his wider plan for the world.

By way of contrast, the Vulgate renders the phrase יפת with bona tempore suo which lays emphasis on the idea of the appropriateness of an action performed at the right time. This would therefore appear to support the position of those who understand the "times" of 3:1-8 as expressing the wisdom concept of acting appropriately. Further evidence in favour of this understanding of the translator's thinking comes from an examination of the Vulgate's rendering of the phrase עמ in in 8:5, 6, which will be considered in the next section. The LXX's

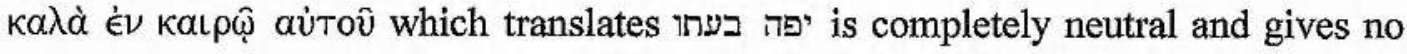
clue as to the translator's understanding of the verse's meaning.

(b) Mediæval Jewish Exegesis

The approaches of the Mediæval Jewish exegetes to the passage 3:1-11 vary as much as those of their more modern counterparts. For example, Rashbam sees in the passage an exposition of divine rule over a just universe: "For everything there is a season: all works have their time and every matter under the heaven has its appointed time - evil times and good times - to pay people their reward according to 
their deeds: payment of evil and payment of good, times appointed for evil and times appointed for good."30) לכל זמן. לכל המעשים יש להם זמן . ולכל חפץ אשר תחת השמים יש לו עת. עתי רעה. עתי טובה. לשלם לבריות משכורתם כפי פעלם. תשלום רע. וחשלום טוב. (עתים של רעה ועתים של טובה. Here we have an idea close to that of Fate. The "times" of humankind are determined by God, but they also have to do with the idea of reward and punishment. Rashbam's interpretation appears to be two pronged, or at least ambiguous. On the one hand, the (human) deeds described in 3:1-8 are the objects of divine judgement. The opposing deeds (e.g. "a time to kill, a time to heal") denote good or evil actions on the part of the person being judged, whilst the opposing emotions (e.g. "a time to weep, a time to laugh") represent the effects of the divine reward or punishment for these deeds.

This is also reflected to some extent in Rashi's comment on $3: 1$, which apparently links this passage with 2:26: "Let not the gatherer of wealth from vanity rejoice, for even though it is in his hand now, the righteous will yet inherit it; only the time has not yet arrived, for everything has an appointed season when it will be." אל ישמח האוסף בהון מהבל כי אם עכשיו הוא בידו עוד יירשורהו צדיקים. אלא שעצדיין לא הגיע) (הזמן כי לכל דבר יש זמן קבוע מתי יהיה. Such an interpretation of the verse certainly fits Qohelet's statement in 3:17 that, "God will judge the righteous and the wicked, for there is a time for every matter and for every deed there." Essentially, Rashi claims that God allows the sinner to gain apparent advantage but that in actual fact, when the time is right, God will right this injustice. Rashi goes on to illustrate this by applying the actions in $3: 2-8$ to biblical events performed by God, or at the command of God. Thus "A time to give birth" refers to the nine month term which God sets for gestation. "A time to die", to the limit of the years of every generation. "A time to plant" refers not to agriculture but to the metaphor of planting a kingdom,

30 Japhet \& Salters, Rashbam on Qohelet,114-15. 
and "a time to uproot" its opposite. Of "a time to kill", Rashi remarks, "an entire nation when the day of its punishment arrives" (אומה שלימה כשמגיע יום פקודתה) and links this to God's judgement in Isa 14:30 on Philistia. "A time to heal" refers to God's healing the penitent in Isa 19:22. Of "a time to break", Rashi comments "the wall of the city, when it is decreed upon it" (הומת העיר כשנגזר עליה), referring to Neh $1: 3$ "and the wall of Jerusalem is breached." Rashi's commentary on 3:1-8 continues in the same vein. Like Rashbam, his reading of 3:1-11 emphasises the lack of human control and the fullness of divine control over events in life.

Rashi remains consistent in 3:11 in the view which he holds regarding Qohelet's thought when he states: "At the time of good, it is beautiful that the reward be given for good deeds, and at the time of evil, it is fitting for the recompense for evil deeds." בעת הטובה יפה היא לכא השלום שכר מעשה הטוב. ובעת הרעה ראויה היא) (להשלום מעשה הרע Such an interpretation of 3:11 is the logical conclusion to Rashi's reading of this passage in which, as we have seen, he understands the actions and their opposites in 3:2-8 as the actions of God rewarding the righteous and punishing the wicked. Essentially, Rashi's understanding of the text is that Qohelet is holding forth on the theme of justice in the world, and making a positive affirmation that all events are divinely ordained, either as reward or punishment. This view is in itself, not far from that of a fatalist since it emphasises the divinity behind events rather than humankind.

Both Rashi and Sforno understand העלם 3:11 as referring to (the wisdom of) the world, but they do so in a way consonant with Qohelet's statement that "humankind should not find out the work of God from the beginning to the end." Rashi remarks concerning God's placement of this wisdom in the לב "heart, mind" of humanity: "He did not put it all into the heart of everyone, but a little to this one and 
a little to that in order that man should not comprehend the entire deed of the Holy One, blessed be He." (לא נתן הכל בלב כל אחד ואחד אלא זה קצת וזה קצת כדי שלא ימצא) (האדם את כל מעשה הקדוש ברוך הוא:

In a similar vein, Sforno comments that God allows humankind a certain measure of knowledge which enables them to gain an overall picture of the world in which they live. Yet God withholds, or humanity is unable to grasp, the details which would make sense of the whole: "He placed in their hearts basic knowledge, with which to master general principles which are eternal...but the specifics cannot

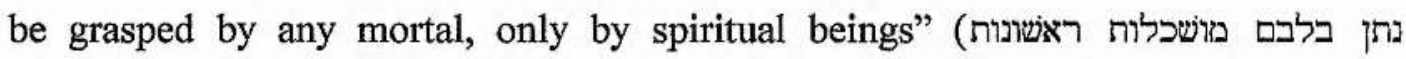
.להשיג בהם כוללים אשר הם לשולם...אבל הפרטים לא ישיג בשכלו כמו שישינו הנבדלים:

Alshich's comment on $3: 1$ is, however, the supreme expression of the possible deterministic reading of the passage under consideration:

הנה שלמה בא לחקור אם עניני ומקרי בני אדם המה ע'פ המזל לשהאדם נולד בו או הכל

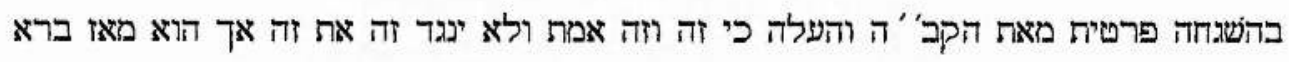

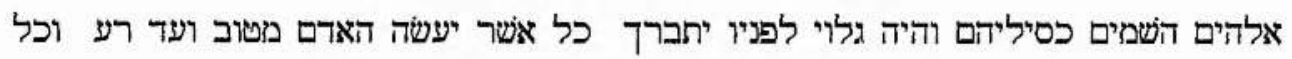

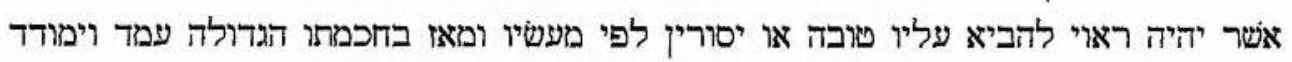
ותיקן שמים באופן לא ישפטו על האדם רק לפי הראוי אליו לפי מעשיו כי לא יביאהו אל העולם רק בעת ישפוט מזלו הראוי לז וזה יאמר שלמה בחכמחו לכל זמן...העת הוא לכל חפץ ובחירת הארם תחת השמים כי עת המזל והחפץ אחד הוא כי השת נתקנה לפי החפיץ

Solomon speculates whether the things which happen to a man are the result of the planet under which he was born or whether they are the result of individual guidance from the Holy One, blessed be He. He accounts both to be true; they are not in opposition to one another. When God, may he be blessed, created the heavens and their constellations, it was revealed to him everything that Man was going to do, be it good or evil, and what was proper to befall them, be it good or evil, according to their deeds. With His great wisdom, he stood and measured and fixed the heavens so that they would judge a man only according to what is proper to befall him according to his deeds. He does not bring a man into the world except 
at the time when his constellation will judge him according to what he deserves. This is what Solomon says in his wisdom: "Everything has an appointed season, ...and there is a time for every desire and choice that man makes under the heavens," for the time of the planet and the desire are one, for the time was designated according to the desire..."

This approach to the passage also features in the commentary of Ibn Ezra, who discusses the viewpoint that the passage concerns "the times which are strong upon humankind, for a human being is bound to do everything in its appointed time, and the beginning of the appointed times and their end restrain him" (העתים שהםם (סמוכות לבן אדם כי חייב אדם לעשות כל דבר בעתו ותהלת העתים וסופם ישהיתו.

Thus it would appear that partial or fully deterministic readings of 3:1-11 were well known and accepted by the Mediæval Jewish exegetes. Metzudath David is in a minority when he understands this passage as emphasising human free will. For him (as for Alshich), ץפח in 3:1 means not "business", but "desire." Thus he states: "For everything that a person desires there is also a time, for a person does not desire the same thing at all times, but at one time he desires one thing, and at another time he desires its opposite, as is delineated in the following verses..." (לכל הדברים שהאדם חפיץ בו גם לו יש עת כי לא בכל עת יחפוץ בדבר אחד כי פעם יחפוץ בדבר מה (ופעם בתלופו וכאשר יפריש במקראות שלאחריו

Again, it is the human element of free will in events which is emphasized as decisive in 3:11 when he remarks on this verse: "Everything that the Holy One, blessed be He, created and made in His world, is all beautiful, but it should be used by them in its designated time, not in any other time." (כל מה שברא ועשה מקדוש ברוך (הוא בעולמו הכל יפה אבל להשתמש בהם בעתם המיזהר להם לא בעת זולת עת: This is a reading which is broadly similar to one modern interpretation, that 3:1-11 deals with the subject of opportuneness. That is, Qohelet plays on the idea in Israelite wisdom 
of finding the fitting moment for an action to enhance its effect. Prov 25:11, which is usually adduced to illustrate this point however, uses the noun "condition." Whereas the NEB's "in season" suggests a temporal aspect to the proverb in question, the AV's "fitly" is probably a more accurate translation.

Metzudath David's interpretation of 3:11 runs into contextual difficulties, however, when he attempts to deal with Qohelet's comment that God has put into the hearts of humanity. He states: "Also all the ways of the world and its benefits he has placed in the hearts of human beings, in order that they might understand them thoroughly if they delve into them profoundly" (גם כל דרכי העולם נותן בלב בני אדם להבינם עד תכליתו אם יעמיקו בהשכל רב ותיעלותיו This is entirely consistent with Metzudath David's earlier comments emphasising the importance of humanity in shaping the events which happen in the world. Yet it is the direct opposite to the intepretations of most of his contemporaries, and all modern commentators. Whether one argues for a deterministic reading of $3: 1-11$, or one in which Qohelet considers the need for opportuneness in one's actions, the vast majority of past and present scholars agree that Qohelet's comments in $3: 11$ preclude the attainment of the required knowledge.

Those commentators who understand 3:1-8 deterministically and who have recourse to the concept of מזל to explain Qohelet's thought in this passage, would appear to be influenced by the interpretation of the Targum. Whether this be admitted or not, however, it is evident that by the seventh century C.E. there was a tradition of reading Ecclesiastes with a strong deterministic slant. 31 Although Qohelet himself shows no interest in astrology, the ease with which Ecclesiastes

31 Following Knobel, The Targums of Job, Proverbs, Qohelet, 13. The dating of Tg. Qohelet is, however, notoriously problematic. M. Ginsburger ("Review of Das Targum zu Koheleth nach sudarabischen Handschrifien herausgegeben von Alfred Levy," ZDMG 59 [1905] 717) argues for a date in the time of the Crusades (i.e, after 1099). This, however, appears unlikely, since Tg. Qohelet is mentioned in Nathan ben Yehiel's dictionary, the 'Arukh, which was completed in 1101. 
lends itself to such readings is suggestive that Qohelet was expressing some concept of determinism. Exegetes of a later age have merely adapted those passages which already show evidence of this idea to the beliefs of their own time.

\section{(c) Modern Commentators}

The term עת has been viewed by commentators in a number of ways. In 3:18 , it is seen by some commentators as exemplifying the ideal of doing the right thing at the right time, which pervaded wisdom literature, 32 and which also occurs in Greek thought. 33 Others understand it in a sense halfway towards determinism and have seen in this passage the Stoic concept of living according to reason, or the logos. ${ }^{34}$ This is not dissimilar to Whybray, who argues concerning $3: 1-8$ that "the things which happen to a man (for example birth and death) and the opportunities which are given to him (for example, planting and uprooting, keeping and throwing away) occur at the time...which God has determined." 35

The majority of commentators, however, argue that 3:1-11 should be understood in a deterministic sense. Thus Fox comments: "The rightness or opportuneness of a particular time is not at issue here. The teaching of 3:1-9 is rather that the occurrence of all human events is beyond human control, for God makes everything happen in its proper time (proper, that is, from his viewpoint)." 36

\footnotetext{
32 O. Loretz, Qohelet und der Alte Orient, 252-53. Cf. also Podechard, L'Ecclésiaste, 285.

33 Ranston, (Ecclesiastes and the Early Greek Wisdom LIterature, 43) citing Theognis 402. Plumptre (Ecclesiastes,127) also mentions the maxim of Pittacus in this connection: KaLpòv $\gamma \nu \omega \hat{\theta} \mathrm{L}_{\mathrm{L}}$ "Know the right season for everything", and the fact that Demetrius Phalerus, the librarian of

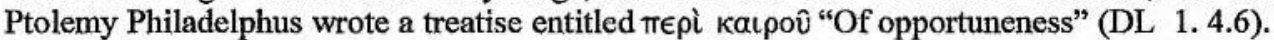

34 Gammie ("Stoicism and Anti-Stoicism in Qohelet," 175) treads a middles path, stating that "Fate, is comparable to Qoheleth's understanding of divine causation (Qoh 3:11; 7:13)", but argues that the catalogue of seasons shows that there are some things over which human beings do have free will, an idea which is also expressed by Blenkinsopp ("Ecclesiastes 3:1-15: Another Interpretation," 58-59). This view ultimately goes back as far as Tyler (Ecclesiastes, 11-12) and Siegfried (Der Prediger, 39) however.

35 Whybray, "Qoheleth, Preacher of Joy," 89. A similar view is suggested by Devine (Ecclesiastes, 56 ), arguing specifically against a full deterministic rendering.

36 Fox, Qohelet and His Contradictions, 192.
} 
Jastrow reads similarly, stating that "Koheleth's thought is, that everything is preordained and the time for its occurrence fixed. Why then toil and worry: Things will happen anyway at the appointed time." 37 Yet while many commentators will agree with the first part of this reading, the force of the rhetorical question in $3: 9$ seems to be rather: "what do human beings get out of all the toil (denoted by $3: 1-8$ ) which the deity forces them to do"?

The same position is taken by Delitzsch, who sees $3: 1-8$ as essentially deterministic in character: "...all happens when and how God wills, according to a world plan, comprehending all things which man can neither wholly understand, nor in any respect change...All that is done here below is ordered by God at a time appointed, and is done without any dependence on man's approbation."38 This line of thought is also followed by Ginsberg, Scott and Murphy. ${ }^{39}$

Podechard mentions such deterministic readings of 3:1-8 and other parts of Ecclesiastes. However, he is also quick to point out that many other parts of the Hebrew Bible "contiennent des affirmations tout aussi inquiétantes pour la liberté humaine" and that human free will is presupposed in many parts of Ecclesiastes $(3: 16 ; 4: 1 ; 7: 15-17 ; 8: 10-15 ; 9: 2-3) .40$ Podechard's argument in these passages about the problem of free will in Ecclesiastes centres on the freedom of humankind to commit actions which Qohelet views as wicked or evil. Human beings appear from Qohelet's experience to be given free rein to oppress their fellows and God appears to have no predictable system to mete out just reward and retribution.

Although God's system for reward and retribution may not be predictable, this is not the same as saying that such a system does not exist. God punishes the

37 Jastrow, A Gentle Cynic (Philadelphia: Lippincott, 1919) 210 n. 41.

38 Delitzsch, Ecclesiastes, 254-55.

39 Ginsberg, Studies in Koheleth, 37-38; Qoheleth, 73-74; Scott, Proverbs Ecclesiastes, 221; Murphy, Ecclesiastes, 33.

40 Podechard, $L^{\prime}$ Ecclésiaste, 192. 
sinner and rewards the good $(2: 26)$, though Qohelet is unable to predict what makes the individual "good before God."41 God would appear to be the missing comforter for the oppressed in 4:1.42 God's attitude towards the righteous individual may be one of love or hatred-which of the two it is cannot be predicted (9:1).43 Good times and bad follow hard upon each other in the life of the individual at the behest of God, without reference to the individual's morality or piety (7:14). Qohelet's God is far from absent in the world, despite Qohelet's statement that "God is in Heaven and you upon earth" (5:1 [Eng. 3]). Here Qohelet emphasises God's power, manifested precisely in his ability to punish those who displease Him (5:5 [Eng. 6]).

In fact, for many commentators, it is in the arbitrary nature of God's actions that Qohelet comes closest to an assertion of determinism.44 Fate is an unpredictable force. Although Qohelet's Jewish culture tells him that there is a God who cares for the righteous and punishes the wicked $(3: 17 ; 8: 12-13)$, his own observations tell him that frequently the innocent suffer and the wicked triumph $(3: 16 ; 4: 1 ; 5: 7$ [Eng. 8]; $7: 15 ; 8: 9-11)$. The logical conclusion to be drawn from this discrepancy would therefore be that either God does not exist, or that God does not take part in the world's affairs. Qohelet, however, draws no such conclusion: he concludes that there is a God, but that he distributes his gifts in a random, unpredictable way (2:26; 5:18 [Eng. 19]; 6:2).

Thus far, this section has demonstrated only that from the very earliest times

\footnotetext{
41 Scholars such as Siegfried (Der Prediger, 38), McNeile (An Introduction to Ecclesiastes, 24), Barton (Ecclesiastes, 84), Podechard (L'Ecclésiaste, 284), Lauha (Kohelet, 58) and Whybray (Ecclesiastes, 64) have for various reasons (usually involving the attribution of the verse to a glossator) understood 2:26 to have a moral content. The majority of recent commentators, however, assign the verse to Qohelet and understand the terms in the sense of "pleasing to God" and "displeasing" (so Hertzberg, Der Prediger, 82-83; Zimmerli, Der Prediger, 161-62; Fox, Qohelet and His Contradictions, 188-90; Crenshaw, Ecclesiastes, 90; Murphy, Ecclesiastes, 27).

42 Glasser, Le procès du bonheur par Qohelet, 74.

43 McNeile, An Introduction to Ecclesiastes, 19; Barton, Ecclesiastes, 157-58; Gordis, Koheleth: The Man and His World, 289.

44 Crenshaw, Old Testament Wisdom: An Introduction, 136.
} 
the passage 3:1-11 has been understood in a number of ways. Indeed, it may almost be said even now that no two commentators agree completely on all aspects of its interpretation. Under such circumstances, how can one decide which, if any, of the interpretations offered is the correct one? Currently, a general consensus exists that the catalogue of seasons gives expression to some form of determinism. This modern consensus is itself a reflection of a very ancient interpretative tradition. The arguments in favour of this position are given by Fox: in 3:11 the text states that God makes everything happen "in its time", while 3:14 suggests that God is the cause of everything that happens. In $3: 17$, the action occurring at a certain "time" is clearly that of God's judgement. Here again, the focus is not on the opportunness or otherwise of human actions, but on a specific activity carried out by the deity, 45

Qohelet's usage of the term עn in the wider context will now be considered in order to see whether he is consistent in his usage of the term and whether its apparent reference to divinely appointed times in 3:1-11 holds true elsewhere.

\section{The Wider Context $(7: 7 ; 8: 9 ; 9: 8 ; 9: 12 ; 10: 17)$}

If the wider context is considered with reference to Qohelet's usage of the term עת , it is possible to come to some provisional conclusions about Qohelet's usage of this term in the catalogue of seasons. It has been demonstrated that a range of views exist on the interpretation of this passage, each of which hinges on he meaning of the term עת. On the one hand, it may refer to an ideal time for each human activity in accordance with which human beings are unable to act. On the other, it may refer to the divinity's imposition of his will on human affairs, making humanity act in a certain way at the time which he has determined.

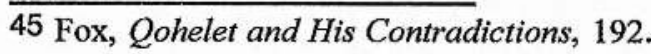


In 7:17, Qohelet advises against being "overly wicked" with the rhetorical question "why should you die before your time?" Qohelet's thinking here is that human wickedness will lead to the ultimate punishment of death from the divinity.46 In this situation, ע cannot refer to an impossible ideal. Rather, it is to the termination of the span of time which the deity has allotted to the individual for his life. The implication is that God chooses the "time" at which one dies, but that this may be revised in the light of subsequent behaviour. 47 The idea that one's death has an "(appointed) time" is also evident in the phrase עת למות in the catalogue of seasons (3:2). The timing of one's death is not usually considered as something over which human beings have any control, and indeed this idea is reflected in Qohelet's statement in 8:8: "No-one has power over the spirit to retain the spirit, nor can one exercise proprietorship in the day of death. There is no substitution in that war..."

\section{$\underline{8: 9}$}

As shall be demonstrated in Chapter 5 of this thesis, the thought of 8:9-10 is intimately bound up with the usage of $\sqrt{ }$. Recently, Seow has pointed out that Qohelet typically uses this root in its technical legal/economic sense of delegated authority.48 It is God who gives to the individual שלטון (proprietorship, authorisation) over goods in 5:18 (Eng. 19); 6:2. Thus, Qohelet's remark in 8:9 that "there is a time (עת) in which one man exercises proprietorship (שלט) over another to his detriment" can be understood as an expression of the inscrutability of the deity's

46 Barton (Ecclesiastes, 144) and Jastrow (A Gentle Cynic, 225) imply acceptance of a certain amount of wickedness on Qohelet's part: it is excess which leads to punishment. Strange (The Question of Moderation in Eccl 7:15-18,90-92) on the other hand, argues that 7:16 reflects the "lesser" wickedness of being self-righteous and corresponding lesser punishment of being "stunned."

47 This indeed is the idea in Job 22:16, cited by Crenshaw (Ecclesiastes, 141), although he sees the death of the wicked individual as the result of action by "angry fellows" or the "authorities" rather than God as such.

48 Seow (Ecclesiastes, 284) sees the term in 8:9 in its technical sense but makes the connection with human authorities as givers of של rather than God. 
rule. The nature of Qohelet's complaint is that God allows one individual to oppress another, so that the deity becomes implicated in human wrongdoing. Thus it is that Qohelet can say in 8:10 that he saw "wicked people approaching and even entering the holy place and they went about the city priding themselves on having done right." 49

\section{9:8}

The context of 9:8 is on the face of it not overtly deterministic, for it is one in which Qohelet offers advice to the disciple: "at all times (בכל עת) let your garments be white and let your head lack no oil." (On the other hand, it is the deity who gives the opportunity for joy to human beings. In $3: 13$, for example, "the gift of God" is the ability "to eat and to drink and to experience the good of all one's toil"). 50 However, the real idea of this verse is that one should utilise the means for having pleasure whatever happens in one's life. 51 The "times" which together make up the life of the individual are beyond human control. The deity alone determines what happens to us, and, by and large, the actions which we perform. However, this text implies that at least some of humanity are given enough freedom to make a choice as to whether to find pleasure (cf. 5:18 [Eng. 19] and 6:2 in which this freedom is denoted by the use of Vשל in its technical sense. This will be dealt with more fully in Chapter 5 of this thesis).

\section{9:12}

The thought of 9:12 has been considered to some extent in the context of

\footnotetext{
49 So NEB, based on a suggested emendation by G. R. Driver ("Problems and Solutions," VT 4 [1954] 230-31). The question of the meaning of 8:9 and its relationship to 8:10 will be discussed in more detail in Chapter 4 of this thesis.

50 Whybray, "Qoheleth, Preacher of Joy," 90; R. K. Johnston, "Confessions of a Workaholic: A

Reappraisal of Qoheleth," CBQ 38 (1976) 25.

51 Whybray, Ecclesiastes, 144.
} 
Qohelet's usage of the phrase עת ופגע in 9:11, but it is worth recapitulating briefly the ideas contained in this passage. The text of 9:12 may be translated "No man knows his time (עת)), like fishes caught in an evil net and like birds caught in the snare, so are human beings trapped by the evil time (עת רעה) when it falls upon them suddenly." The term עת in this context cannot possibly refer to an ideal time in accordance with which human beings cannot act. The point of this passage is that "time" seeks out and finds human beings rather than vice versa.52 As such, the use of the term עת has a clearly deterministic flavour: it catches $(\sqrt{ }$ עח $)$ and ensnares ( Vop' human beings. The entrapment imagery of 9:12 captures perfectly how the divinely appointed "time" restricts human freedom (cf. the imagery of binding used by Ibn Ezra in his comment on 5 in 3:1).

The deterministic flavour of this passage is brought out still further by the use of the term מצודה which is typically used of the divine net which is wielded by Yahweh and by means of which he executes judgement upon the human world (Ps 66:11; Ezek 12:13; 17:20, cf. מצוד in Job 19:6). 53 Gordis rightly points out that the adjective רעה applied to the "net" and the "time" has no moral content. Rather, both are "evil" from the standpoint of the victim, which Qohelet adopts. 54

\section{$\underline{10: 17}$}

The use of the term עת 10:17 does not appear to have deterministic overtones. The text, which may be translated, "Happy the land when its king is nobly born, and its princes feast at the appointed time (בעת), for strength and not for drunkenness" nevertheless does not express the wisdom ideal of acting at an "ideal

52 J. A. Montgomery ("Notes on Ecclesiastes," JBL 43 [1924] 243) in fact translates עת מ here as "fate" and makes specific reference to 3:1 in this context. Cf. McNeile (An Introduction to Ecclesiastes, 79) who calls the passage 9:11-12 "a poetical expression of the thought of iii 1-9."

53 Rudman, "Woman as Divine Agent in Ecclesiastes," JBL 116 (1997) 417.

54 Gordis, Koheleth: The Man and His World, 298. 
time." If one considers this concept in the wisdom tradition, the idea of performing an action at the right time is to maximise its effect. Here, the "appointed time" for the action of his subjects is imposed by the king who rules wisely. In this respect, there is a clear parallel to the action of God who enforces "appointed times" for all actions on his human subjects.

\section{(d) Conclusion}

Although the thoughts of commentators as to the meaning of $3: 1-11$ have differed significantly over the centuries, it is possible to reach some conclusions about the passage based on Qohelet's use of the term עת elsewhere. Qohelet never uses this word elsewhere to denote the idea of an ideal time in accordance with which human beings should act. Rather, it occurs in the sense of an "appointed time" which is imposed from without, in accordance with which the object must act. Many of the passages in which the term occurs imply the role of the deity in the imposition of these times, although 10:17 forms an exception to this rule. Even here, however, the sense of a time which is enforced is paramount.

This would therefore appear to suggest that the catalogue of seasons represented by $3: 1-8$ should be interpreted as expressing the idea of a wideranging deterministic influence in human affairs. Evidence from the wider context therefore supports a deterministic reading of 3:1-11 which, as well as being accepted by the majority of modern commentators, can be traced through some of the Mediæval Jewish exegetes such as Ibn Ezra and Alshich to the Targum.

One way in which this conclusion about the nature of $3: 1-8$ might be refuted is by the suggestion that the catalogue of times and seasons is a text which is quoted by Qohelet and reinterpreted in 3:9ff. Thus one might argue that the sense in which עת occurs in 3:1-8 differs from Qohelet's own usage elsewhere. The idea that 3:1-8 
may not be the work of Qohelet is a relatively old one. However, Blenkinsopp has recently used it to argue against the idea that Qohelet's deterministic worldview is as wideranging as this passage would appear to suggest (although he does accept the idea that Qohelet advances the concept of a limited form of determinism elsewhere). 55 This view, and the arguments against it, will be considered in Chapter 3 of this thesis.

$\overline{55 \text { Blenkinsopp, "Ecclesiastes 3.1 }}$-15: Another Interpretation," 55-64. 


\section{4. טפטש}

The noun משפט occurs 6 times in Ecclesiastes (3:16; 5:7 [Eng. 5:8]; 8:5, 6; $11: 9 ; 12: 14)$. Of these usages, two clearly refer to examples of human injustice $(3: 16$; 5:7 [Eng. 5:8]), one forms part of the final editorial addition to the book, asserting a traditional view of divine judgement (12:14),56 and another is probably a gloss influenced by this editorial addition (11:9). 57 Whereas broad agreement exists on the meaning of all these examples, Qohelet's usage of the term משפט in 8:5,6 has failed to attract a similar consensus. 58 It is notable, however, that Qohelet uses the term parallel to ("appointed time") in both verses. Having argued in this chapter that the latter term is indicative of a belief in determinism on the part of Qohelet, an examination of 8:5, 6 is therefore necessary to consider whether Qohelet's use of the noun משפט in these locations may also have deterministic overtones.

The Hebraic concept of judgement in which punishment or reward are meted out by the deity is in some respects similar to fate. This resemblance becomes more pronounced in the work of Qohelet, who considers that divine justice is ineffable and that God rewards whoever pleases him without respect to moral worth. This is a theme upon which Crenshaw remarks: 59

\footnotetext{
If we cannot determine our future, no matter how hard we try, God's disposition towards us becomes a matter of life and death.....Men and women possessed no control over the goods which God dispensed in his own time and manner. Not even morality purchased the best gifts, and often good people waited in vain for
}

56 Crenshaw, Ecclesiastes, 192. Lauha (Kohelet, 223) suggests in fact that the reference in 12:14 is to a judgement after death.

57 Siegfried, Der Prediger, 73; Barton, Ecclesiastes, 185; McNeile, An Introduction to Ecclesiastes, 26; Podechard, L'Ecclesiaste, 452. More recently, some commentators have argued for the retention of 11:9b, including Gordis (Koheleth: The Man and His World, 336) and Whybray (Ecclesiastes, 162).

58 Siegfried (Ibid., 63), McNeile (Ibid., 25) and Barton (Ibid., 150) also attribute 8:5-6a to the same Toח glossator as 11:9b.

59 Crenshaw, Old Testament Wisdom: An Introduction, 136. 
signs of divine favour, while rich rewards speedily greeted evil acts. In short, the trouble with gifts was that God retained control over them. In a sense then, God forced men and women to rely on him for everything...The inevitable course of such thinking would seem to be some form of determinism.

Many commentators recognise, for example, that when Qohelet speaks of the one who is "good before God" (טוב לפני האלהים) and the sinner (חוטא) in Eccl 2:26, he does not use these terms in a conventional moral sense. Rather, the situation which Qohelet describes is illustrative of God's inscrutable judgement.60 As Murphy remarks, "the import of the verse is to claim sovereign freedom for God in imparting gifts."61 Those, such as Podechard, who would seek to retain a moral dimension to these terms, are forced to to recognise a gloss in 2:26a (by a Tron seeking to tone down the content of Qohelet's assertions). 62

Can the difficult passage $8: 5-6$ be understood in the light of such a deterministic concept of judgement, or should the phrase עת ומשפט ("time and judgement") occurring in both be applied to the courtly wise man's savoir faire, his ability to act in the proper time and manner and hence to escape the wrath of the despotic king depicted in 8:2-4? In order to determine this, these two verses will now be considered and then related to the wider contexts of the preceding verses and Qohelet's thought elsewhere in Ecclesiastes.

\section{$\underline{8: 5}$}

The keeper of a commandment shall know no evil thing,

60 Ginsberg ("The Structure and Contents of the Book of Koheleth," in M. Noth \& D. W. Thomas [eds.], Wisdom in Israel and the Ancient Near East [VTSup 3; Leiden: Brill, 1955] 13), states that these terms "mean respectively (as is today generally recognised) 'pleasing to God' or 'displeasing', or 'lucky' and 'unlucky' - not 'righteous' and 'wicked'. This applies not only in ii 26, but also e.g. in vii 26."

61 Murphy, Ecclesiastes, 27.

62 Podechard, L'Écclésiaste, 284. 
for a wise man's mind knows time and judgement.

\section{(a) The Versions}

\section{(i) The Septuagint}

This verse can be interpreted in two distinct ways, and much depends on

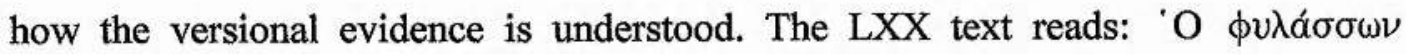

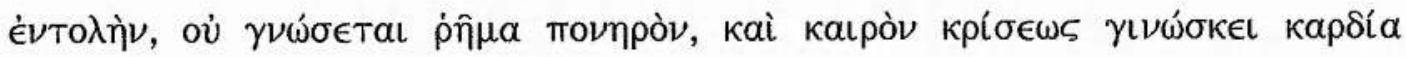
бoфov ("He who keeps a commandment shall not know an evil thing: and the heart of the wise knows the time of judgement."

The argument advanced by Fox, that the MT"s עת ומשפט ("time and judgement") in 8:5 is a hendiadys equivalent to עת משפט ("time of judgement"), is

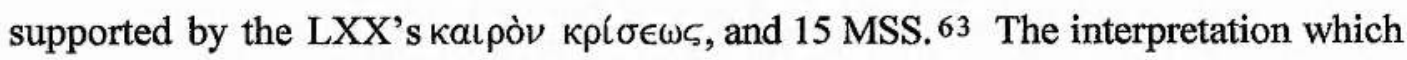
follows from such a reading is that the phrase עת ומשפט refers to divine judgements on human evil (possibly connected with the despotic king depicted in the preceding verses). 64 The wise man knows that "God will judge the righteous and the wicked" (3:17). This interpretation is therefore in line with Qohelet's thought in 3:17, but also retains the idea of עת as a time appointed by God for a purpose.

\section{(ii) The Vulgate}

The Vulgate text of this verse reads, Qui custodit prceceptum, non experietur quidquam mali. Tempus et responsionem cor sapientis intellegit ("He who keeps a commandment shall experience no evil. The heart of the wise man understands time and the reply"). On the question of whether the phrase פת ומשפט in 8:5 should be translated as a hendiadys, Crenshaw points to the LXX translation of the same

63 Fox, Qohelet and His Contradictions, 247-48.

64 So Lauha, Kohelet, 149. 


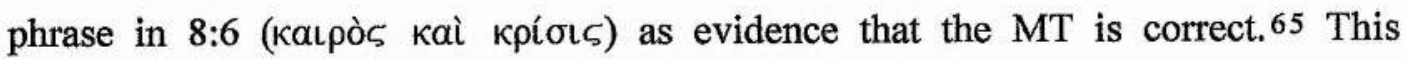
conclusion and the naturally following interpretation is supported by the Vulgate's translation, tempus et responsionem ("time and the reply") which understands משפט in its rare sense of "proper procedure" (Isa 28:26; $1 \mathrm{Kgs} \mathrm{5:8;} \mathrm{Isa} \mathrm{40:14).} \mathrm{This} \mathrm{is} \mathrm{the}$ approach adopted by Gordis, who refers it to the wise man's ability to respond appropriately to external events. 66 Such an interpretation is consistent with Qohelet's advice in 8:2-4 on how to react (or rather, how not to react) to the actions of one's ruler, even when they are questionable.

\section{(iii) The Targum}

The Targum reads, גבר די נטיר פקודיא דיי לא יעדע מרעם ביש לעלמא דאתי ועידן צלותא ודין וקשוט אשתמודע בלב חכימיא A man who keeps the commandments of the Lord will know no evil thing in the world to come and the time of prayer and judgement and righteousness, are made known in the heart of the wise"). The Targum to some extent supports the position of Fox on this question since it appears to understand עת ומשפט a a hendiadys and translates with a genitive construction. However, it also supports the MT in that it has the conjunction before the equivalent of משפטט.

(iv) The Peshitta

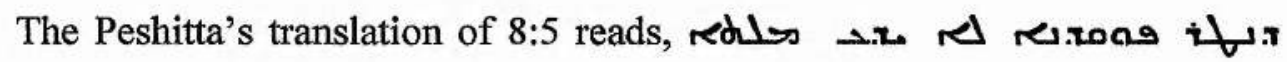

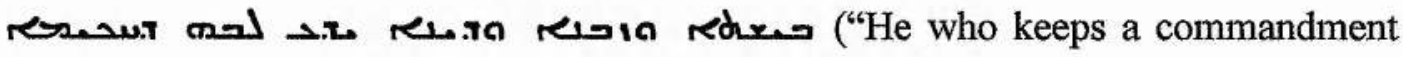
will not know any evil thing, and the wise man's heart knows time and judgement"). This translation is a fairly literal one and supports the MT.

65 Crenshaw, Ecclesiastes, 151. Fox (Ibid., 248) takes the evidence of 8:6 in quite the opposite sense, arguing that ומ in in 8:6 should be omitted, since it may have been added under the influence of the word in the previous line.

66 Gordis, Koheleth: The Man and His World, 289-90. 


\section{(v) The Arabic Version}

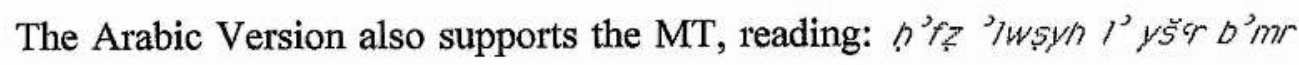

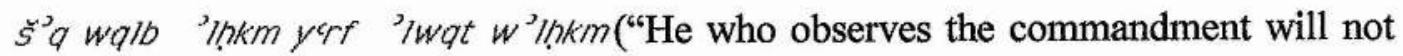
know a troublesome matter, and the heart of the wise man knows the time and the judgement").

From the above, it may be seen that the versional evidence appears to be split as to whether or not the MT's עת ומשפט should be translated as a hendiadys. As we have seen, the answer to this question does make a material difference to the possible interpretation of this verse, and so it will be necessary to consider the views of later commentators and the evidence of the wider context in some depth. Before proceeding with this enquiry, however, it is worth noting that the MT's לב חכם is taken as a construct by all of the Versions cited here and consequently translated "the heart of the wise man", although Gordis reads a a a adjective rather than a noun, and translates "a wise heart." 67 No material difference to the exegesis is made whichever option is followed. Since Qohelet's use of the definite article is far from consistent, my own translation also understands the phrase as a construct, following that of the Versions.

\section{(b) Mediæval Jewish Exegesis}

Unfortunately, the interpretations of the Mediæval Jewish exegetes differ considerably, reflecting the difficulty of the passage. Rashi on one hand comments: "The wise man knows that there is a time ordained for the punishment of the wicked, and there are judgements before the Holy One, blessed be $\mathrm{He}$, with which he will recompense them in the end" (החכם יודע שיש עת קבוע לפקודת רשעים ומשפטים

67 Gordis, Koheleth: The Man and His World, 289. Followed by Crenshaw (Ecclesiastes, 151). 
(יש לפני הקב"ה שסופן להפרע מהם the possibility of the hendiadys for which Fox argues based on the evidence of the LXX and some manuscripts.

However, Metzudath David expresses a different view of the passage: "Although it is true that one may not obey [a king] to break one of God's commandments, not all times are the same. There are times when one must break a commandment in order to obey a king's command, to make a fence and a safeguard. Likewise there is sometimes a ruling, which the kingdom decrees upon all its people, which it is proper to obey although it is to break a commandment" (אם אמנם אין לשמוע לעבור על אחת ממצות האלהים אין כל העתים שיות כי יש עת לעבור...על המצוה למען שמוע דבר המלך לעשות גדר ומשמרת וכן יש דבר מנהג המלכות הגוזר על כל אנשו שמהראוי לשמאוע לה ואה היא לעבור על המצות Interestingly, Metzudath David relates the term ע to its use in 3:1-8: there the times of which Qohelet speaks are enumerated in opposites, as when Metzudath David speaks of the time to keep and to transgress God's commandments. Thereby he continues his insistance on human free will as the defining force in life which was evident in his exegesis of 3:1-11. The term משטמש in this context refers to the ruling which is instituted by the kingdom, the necessary observance of which will result in such a transgression.

Sforno's interpretation of the passage is in some respects similar to that of Metzudath David. He explains: "One who keeps and studies a commandment will not find anything bad in it, that is; no lack of purpose, and a wise man's heart knows the time and the judgement. He knows and understands the time the commandment is to be observed and the reason it was given" שומר ומחבונן בפצוה לא ימצא בה רע) שהוא חסרון חכלית...ועת ומשפט ידע לב חכם. ידע ויבין העת שנתנו בו המצות ומשפט והטעם למה ברתו). 
Thus the views of the Mediæval Jewish commentators in general anticipate the conflicting views of modern commentators on the exegesis of 8:5. On the one hand, Rashi sees "time and judgement" as unalterable defined by the will of God in much the same way as Fox and Murphy. On the other, Metzudath David and Sforno agree in seeing "time and judgement" as being ultimately subject to the will of human beings as do Gordis and Whybray, although they divorce the commandment of 8:5 from the context of court wisdom to that of divine law.

\section{(c) Modern Commentators}

The opinions of modern commentators, as has already been illustrated, vary as widely as those of the more distant past. Fox's position, that 8:5-6 expresses the idea that human evil will be judged by God, has already been noted.68 Gordis, like Fox, suggests the possibility that עת ומשפט is a hendiadys, but interprets it to mean "the time of propriety = the proper time." However, עת alone could be equally well rendered thus (Deut 11:14; Jer 5:24; 2 Kgs 5:26; Ps 119:126), whilst משפט could be rendered "the proper procedure" (Isa 28:26; $1 \mathrm{Kgs} \mathrm{5:8;} \mathrm{Isa} \mathrm{40:14).69}$

Gordis's translation of 8:5-6 is an unusual one, though it illustrates the fact that he favours the second translation for עת ומשפט: "He who keeps his command will experience no trouble, for a wise mind will know the proper time and procedure. For everything has a proper time and procedure, man's evil being so widespread." 70 Nevertheless, his understanding of the way that $8: 5$ is linked to $8: 6$ has not gained acceptance among recent commentators.

Crenshaw's interpretation of the verse is broadly similar: "The basis for such

68 The suggestion was also made by Plumptre (Ecclesiastes, 176-77). Plumptre (unlike Fox), however, retains MT.

69 Gordis, Koheleth: The Man and His World, 289. This idea, as we have seen, is the idea expressed in the Vulgate's translation.

70 Ibid., 182. 
confidence (i.e. that those who obey a command will not suffer by so doing) rests in the intelligence of one who understands the proper time and manner for action."71 However, he argues that the viewpoint of Qohelet in this verse does not represent his true understanding of reality since he immediately contradicts his apparent confidence in 8:5 when in 8:6b-7 he makes the statement that humankind cannot know what will be. Whybray agrees with this viewpoint, stating that $8: 5 \mathrm{a}$ is a "commonplace of traditional wisdom, cited by Qohelet as a dictum to be attacked", although he also lists the possible interpretations of this verse: "(i) that the obedient man will steer clear of involvement in intrigue because, as a wise man, he will be aware of the probable penalty, (ii) that he will be afraid of divine retribution if he does wrong, or (iii) that he may take comfort in the knowledge that even tyrants have only a time to rule and must face God's judgment." Whybray nevertheless argues that none of these alternative interpretations do full justice to the context of the verse, which is strongly linked to the previous verses by vocabulary such as and 72.דבר רע

Thus far then, there seems to be no clear consensus on the meaning of 8:5, although all are agreed that it is connected in some way with 8:6-7 and with the preceding verses. This consideration of the passage will therefore seek to address the question of whether Qohelet's statements in 8:5 can be reconciled with those in 8:67 , and if so, how this can be done.

\section{$\underline{8: 6-7}$}

Because to every purpose there is time and judgement, therefore the misery of man is great upon him.

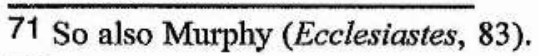

72 Whybray, Ecclesiastes, 131-32. 


\section{(a) The Versions}

\section{(i) The Septuagint}

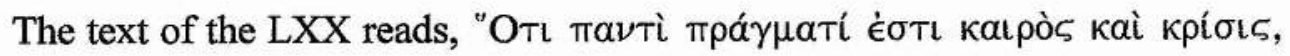

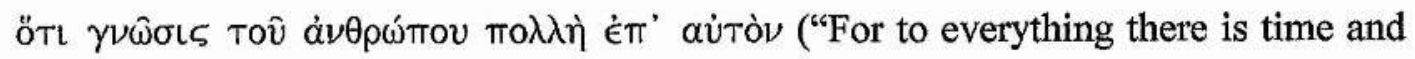
judgement, for the knowledge of a man is great to him"). The different LXX renderings of the expression עת ומשכט and the possible reasons for them have already

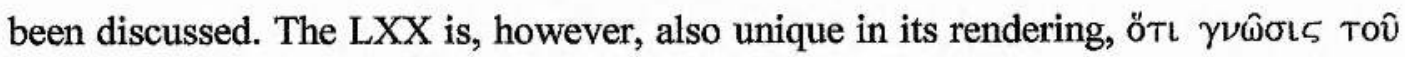

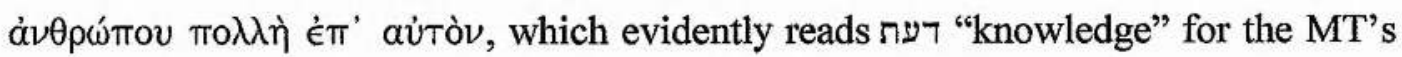
"evil." The context indicates that the MT in this case is to be preferred, and as we shall see presently, this is confirmed by the interpretations of modern commentators.

\section{(ii) The Vulgate}

The Vulgate reads, Omni negotio tempus est et opportunitas et multa hominis afflictio ("For every business there is a time and appropriate moment, and great is the distress of man"). The MT's לכל חפןץ would seem to be an obvious echo of 3:1, suggesting a similar interpretation of the noun עת should be made in this passage, and in fact the Vulgate's translation of the term משפט by opportunitas would appear to be an attempt to link this verse with both its interpretation of $8: 5$ as indicative of the wise man's ability to know the right time and appropriate response to external events, and with the catalogue of times and seasons in 3:1-8. However, it should also be noted that the translator of the Vulgate has been forced to translate the term משפט in two different ways in order to maintain a coherent exegesis. Whereas responsionem in 8:5 refers to the wise man's reaction to events, his own subjective "judgement" as it were, opportunitas in 8:6 refers objectively to the fixed time itself. Thus, either the translator does not translate "judgement" in 8:6 or he understands it 
as God's judgement which establishes the fixed time, in accordance with which the wise man should act.

\section{(iii) The Targum}

ארום לכל עסקא אית עידן טב וביש ועל דין וקשוט אתדן כל עלמא, The Targum reads וכד אתגזר מן קדם "י למהוי פורענותא בעלמא על חובת אנשין עבדי בישא דסגיאין עלויהון ("For to every business is a good and evil time and by Justice and Righteousness the whole world is judged and when it is decreed from before the Lord that there will be punishment in the world on account of the people, the doers of evil which is great against him..."). The midrashic material within the text demonstrates that the translator made a contextual connection with $3: 1$ and the list of opposites in $3: 2-8$ ("to every business is a good and evil time"). However, this translation is also indicative of the Targumist's view that the noun משפט refers to divine judgement occurring in the here and now, punishing sinners. The limitation of the Targumist's interpretation is that it disconnects "time" and "judgement" when Qohelet apparently sees them as interrelated, perhaps one and the same.

\section{(iv) The Peshitta}

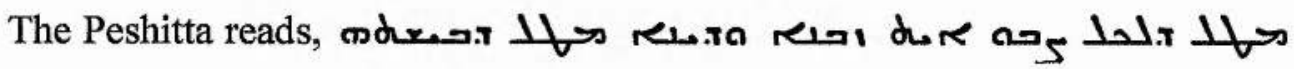
("Because to every business there is time and judgement, therefore the evil of man is great upon him"). Again, this is a literal translation which des not offer significant help in interpreting the passage, although it bears witness, as do all the versions to the conjunction in the MT's עת ומשפט.

(b) Mediæval Jewish Exegesis

Rashi interprets this verse, understanding the term משפט 
punishment of the sinner (though he also interprets ran "business" in the sense of "desire"): "When a person acts out his desire and transgresses the law, there is a time to punish him, and justice and punishment are ready" שהאדם עושה חופצו ועובר על) דת ישט עת להפרע ומשפט ופורענות מוכנת . Likewise, he states, "When the evil of man is כreat and his measure is heaped up, then his punishment arrives" (כאשר רבה רעת) (האדם וסאתו גדושה אז באה פקודתו . Rashi's interpretation of this verse is pietistic but his insight that the term משפט refers to divine judgement should not be dismissed. The term has, after all, a legalistic overtone throughout the rest of Ecclesiastes and God is the subject of the verb elsewhere in phraseology which is closely related (3:17).

The position of many modern commentators on $8: 6$ is exemplified by Metzudath David: בתחלת המחשבה אין דארם יודי להשכיל מה שיהיה לאחרונה למען דעת ממנו העת ודמשפטט (When beginning to think, no man knows how to consider what will happen in the end in order to know from it the time and the judgement"). This understanding clearly links "time and judgement" to the thought processes of the sage: since one cannot say for sure how one's actions will turn out, it is impossible to make a correct decision on how to act and when to act. Once again, one can see the debate as to the meaning of this passage polarised between those who link "time and judgement" with God's activity and those who would place it within the human sphere of operations.

\section{(c) Modern Commentators}

The four instances of 2 in this verse and the next cause an interpretive problem. Crenshaw favours a reading of $8: 6$ in which the first 2 is taken asseveratively, and the second adversatively, i.e. "Indeed, for everything there is a time and a procedure, but the evil of human beings is heavy on them." However, as 
Crenshaw himself points out, other interpretations are possible and indeed, have been offered. 73

It is also possible that $8: 6 \mathrm{a}$ is a restatement of the viewpoint of traditional wisdom. Certainly, the language of this section is reminiscent of $3: 1$. Gordis argues that the language of this verse, which speaks of "human evil" being too heavy for humankind, refers to the inherent weaknesses of humankind. Thus, a wise courtier, who knows the correct time and procedure, will always find an opening which will allow him to use his skills. ${ }^{74}$ Such an interpretation is problematic however, since the term אדם must presumably include the wise man, and in fact, the wise man is portrayed as being powerless before the king $(8: 2-4)$. It is not the wise man who instructs in this situation which Qohelet describes, but his ruler.

Murphy and Fox both deal with the interpretation that even for a king, there is "time and judgement." In other words, a king may indeed do as he pleases in the present, but he is not excluded from the judgement of God, who will punish his sins (however unknowable the future is to humankind - v. 7) 75

\section{(d) Synthesis: Text and Context}

Most commentators recognise some form of relationship between 8:5, 6 and 3:1-8 and/or 3:17 regarding Qohelet's use of the term עמת "time." As we have seen, however, the term משפט has been interpreted in a number of ways; as being indicative of the judgement of the wise regarding the correct procedure to follow at court (especially when faced with a despotic king), or of the judgement of God over the king or over wickedness in general.

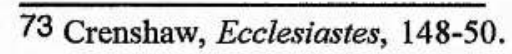

74 Gordis, Koheleth, the Man and his World, 290; Scott, Proverbs Ecclesiastes, 240.

75 Murphy, Ecclesiastes, 84; Fox, Qohelet and his Contradictions, 247-48. Seow (Ecclesiastes, 281) also understands עת ומשפט as a reference to God's judgement, but divorces 8:5bff. from the preceding courtly verses. 
Fox's assertion, that these verses consciously pick up on the language of $3: 17$ is the most convincing of the arguments that have been advanced about the interpretation of this passage. 76 Qohelet states in 3:17: "I said to myself (lit. 'in my heart'), 'the righteous and the wicked, God will judge', for there is a time for every purpose and concerning every work there" אמרתי אני בלבי את הצדיק ואת הרישע ישפט (האלהים כי עת לכל חפץ ועל כל המעשה שם . Thus we see the use in one verse of the

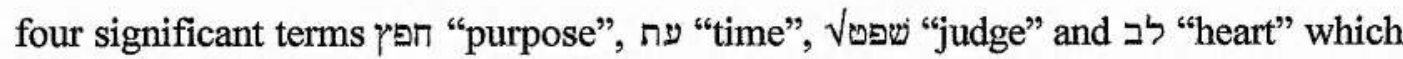
feature in the verse under consideration. In 3:17, Qohelet demonstrates the truth of his statement in 8:5 that "the wise man's heart knows time and judgement." However, the essence of Qohelet's concept of $\mathrm{N}$ is that the point at which an appointed time for action will occur is unknowable. This is explicitly stated in 9:12, but is also reflected in 8:7, "for he knows not that which shall be, for who can tell him when it shall be."

\section{(i) ומש עש as "Proper Time and Manner of Procedure"}

If one understands with Whybray the term עת to mean an ideal time for action in line with which human beings cannot act, it is difficult to see a convincing link between $8: 6-7$ :

Because to every matter there is time and judgement, therefore man's misery is great. For he does not know what will happen, for who will tell him when it will happen?

Even though one may not act in accordance with an "ideal time", one usually knows what will happen as a result of one's actions. Of course, one could object at this point with Metzudath David that this is true only in a general sense. One cannot foresee in detail the consequences of a given action with any certainty. However, the

76 Fox, Ibid., 247. 
problem with this reading becomes more pronounced when one considers Qohelet's avowal that human beings do not know "when it will be." If human beings have free will, then they know when they will act. The only way both parts of $8: 7$ can be interpreted in line with the concept of 5 as an ideal time is to refer each part to different things, the "what" to the outcome of human actions not in line with the "ideal time" and the "when" to the arrival of the ideal time itself. Perhaps more seriously, Qohelet only uses Vשפ outside this passage in a legal sense $(3: 16 ; 5: 7$ [Eng. 5:8]). Both of these considerations argue against the understanding that ע means "Proper Time and Manner of of Procedure."

\section{(ii) עת ומשפט as "Time of Judgement"}

Fox's understanding of the phrase עת ומשפט in 8:5 as a hendiadys meaning "time of judgement" cannot be transferred to $8: 6$. The resultant translation, "Because to every business there is a time of judgement, therefore human misery is great", makes little sense. The idea that God might judge all human action in the traditional way would be rather comforting to Qohelet, who complains elsewhere on the tardiness or even lack of such action on God's part (8:11).

It is for this reason that Fox, following Ginsberg, is forced to emend the text of 8:6 by deleting ומשפט as an addition added under the influence of 8:5.77 This is a rather desperate measure: the more so since Fox has already suggested a quasiemendation to 8:5 in order to harmonize with his view of what Qohelet ought to be saying. Certainly, the resultant text of $8: 6-7$, "Because to every matter there is a time, humanity's misery is great: for he knows not what shall be, nor when it shall be" makes perfect sense, and is entirely in keeping with Qohelet's thought as it is expressed in the catalogue of times in 3:1-8. However, the term משפט $8: 6$ provides

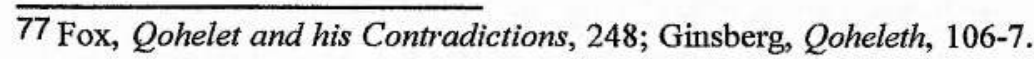


an important link with the thought of $8: 5$. If it is deleted, then $8: 6-7$ is left in isolation and without context. Before taking such drastic action, it is as well to consider whether the term מש can be retained in 8:6 and understood in a way consonant with Qohelet's thought elsewhere.

\section{(iii) עת ומששפט as Determinism}

What does Qohelet mean when he makes God the subject of Vuve elsewhere in Ecclesiastes? Almost all commentators would agree that he refers to the divine intervention in the here and now (as opposed to a judgement after death). ${ }^{78}$ This judgement is considered to be of the familiar form in which a specific human action is met with a corresponding response of reward or retribution from God. However, if all (or nearly all) human actions are controlled by the deity, then the rationale for such a system falls away. One might reasonably argue that a belief in determinism and a traditional judgement is simply one more of Qohelet's contradictions, yet Qohelet in 8:5-6 juxtaposes the terms מששפט, thereby emphasizing the connection between the concept of judgement and the key word which expresses his deterministic thought.

We have seen that one way of understanding these verses is to connect them with the catalogue of times and seasons in $3: 1-8$ and to understand them deterministically (as Fox does). The form of 8:6, כי לכל חפיץ ישי עת ומשפט would appear to be a simple restatement of 3:1, עת לכל חפץ. Thus, one might paraphrase the thought of $8: 6-7$, "Because all human business is predetermined by God, human beings are in a distressing position: for they do not know what will happen or when anything will happen."

78 Gordis (Koheleth: The Man and His World, 235) sees an ironic reference to a judgement in the afterlife in 3:17. Lauha (Kohelet, 223) similarly construes the editor's reference to a judgement in 12:14. 
One may object that this interpretation does not interpret the term "judgement" and that therefore Fox is correct in deleting ומשפט 8:6. This is in fact unnecessary, however, for the imposition of "appointed times" is based on God's inscrutable judgement of the individual. In 2:26, Qohelet speaks of God giving "wisdom, and knowledge and joy" to "the one who is good before God", while God "gives to the sinner toil: to gather and to heap up to give to one who is good before God." It is perhaps no accident that this passage, with its series of infinitives denoting the divinely determined עניץ given to the sinner, immediately precedes the ענין (3:9) represented by the catalogue of times (3:1-8). Likewise, in 7:26, whether the individual male is trapped by Woman is determined by whether he is "good before God" or a "sinner." Whether one loves or not (cf. 3:8 "a time to love") is a consequence of how one is viewed and judged by the deity in this passage. The activities which human beings are made to perform (and their outcome) are a direct consequence of whether we are viewed by him as טופא or. Thus, "to every business there is time and judgement."

What of the preceding passage, $8: 2-4$ ? Can this view clarify the advice offered by Qohelet in a courtly context? Since I have argued that the statement "to every business there is time and judgement" refers in a general way to God's activity in the world and is expressing the idea that one's position and the activity one carries out is a reflection of divine favour or disfavour, it is interesting to note that God is mentioned in connection with the king in the very first verse of this passage (8:2): "I counsel you to keep the king's commandment, in regard to the oath of God" (פי (מלך שממר ועל דברת ששבועת אלהים . This passage will in fact be considered in more depth in Chapter 5, which explores Qohelet's conception of free will. For now, it is worth noting that both Tyler and Hertzberg have advanced an interpretation of the 
verse in which Qohelet advises obedience to the king because of God's oath concerning kingship. ${ }^{79}$ That is, the king has a specially favoured status with respect to God, thus one should "keep" (שמור) the king's law. In 8:5, Qohelet says "one who keeps (שימר) (the king's) commandment will not experience problems: the heart of a wise man knows 'time and judgement." In the light of the king's special position with God and Qohelet's consequent advice to be obedient in 8:2, one can interpret 8:5 as saying "a wise man will obey the king because his situation, like everyone else's, is divinely ordained." In effect then, 8:5 would be a restatement of the thought of $8: 2$, and $8: 6-7$ would be not so much a contradiction of the thought of $8: 5$ as a coda based on the term "time and judgement", widening its application from a courtly situation to existence in general.

\section{(e) Conclusion}

This section has sought to demonstrate that Qohelet's use of the phrase has deterministic overtones and that the ideas expressed in 8:5-6 are in line with the deterministic meaning claimed for the catalogue of seasons in $3: 1-8$. In doing so, the two main current interpretations of 8:5-6 have been examined.

The idea that עת ומשפט in these verses refers to the sage's ability to determine the proper method and procedure ignores the context of 3:17 where similar phraseology is used of God's judgement. Moreover, a problem occurs in that there appears to be no causal relationship between this understanding of the phrase and the thought of 8:7 in which Qohelet clearly laments humanity's inability to know what the future holds for them.

Fox's solution to the problem represented by these verses, in which עת ומשפטט

\footnotetext{
79 Hertzberg, Der Prediger, 141-43. The essential details of Tyler's reading (Ecclesiastes, 101-2, 139-40) are the same as mine: (i) that the King is a divine viceregent and symbol of law (ii) that this provides the rationale for Qohelet's advice to obey the king, and (iii) that the phrase עת ומשפט "Season and Law" refers in a general way to God's determinative activity in existence.
} 
in 8:5 is translated as a hendiadys with the "judgement" being understood in a traditional way, and the phrase ומשפט in 8:6 then deleted, is, however, somewhat arbitrary. As far as possible, the text as we have it should be retained and an attempt made to understand it against the background of Qohelet's thought elsewhere.

Thus, it is best to understand פת ומשפט almost as synonyms: God's inscrutable judgement unfolds in the actions which the individual is made to perform and the course of their life. Human distress (8:6b) is a natural concomitant for they have no control over the course of their own lives: they do not know what will happen or when things will change (8:7 cf. 7:14). In many ways, the situation of humanity is a larger scale reflection of the sage at court, continually at the mercy of the despotic king in 8:2-5. By juxtaposing both pictures, he succeeds in drawing a lesson for humanity in general from the rarified atmosphere of the court wisdom genre. 


\section{5. חל}

Another way in which Qohelet's deterministic worldview can be seen is in the concept of $\pi$, or "portion." This term occurs 8 times in Ecclesiastes $(2: 10,21$; $3: 22 ; 5: 17,18 ; 9: 6,9 ; 11: 2)$ but is also common throughout the Hebrew Bible. However Qohelet again, as shall be demonstrated, uses this term with a nuance of meaning and in contexts different to those in which it is found in the rest of the Hebrew Bible.

The term is used in the Hebrew Bible in a number of ways. M. Tsevat describes the primary meaning as "...the portion coming to one by law and custom." From this meaning develops the meaning 'the portion in life determined by God,' "destiny.""80 Primarily, the term חלק is connected with the organisation of the community or the family (Prov 17:2; Neh 13:13; 2 Sam 19:30 [29]). However, sometimes it can refer to the division of land. Since Yahweh is depicted as the original owner of Palestine (e.g. Deut 12:10), someone who receives a portion of this land (Num 26:53; Josh 18:5; 19:51) is said to have a portion in Yahweh's own property. Similarly, one who renounces his portion of the land may be said to have no portion in Yahweh (Josh 22:25, 27). 81 By way of contrast, the Levites, are said to have no portion (חלק) in Palestine, since they are not entitled to own land (Num $18: 20$; Deut $10: 9 ; 12: 12 ; 14: 27,29 ; 18: 1 ;$ Josh $14: 4 ; 18: 7)$. Rather, their portion is Yahweh himself (Num 18:20), an idea which is expressed in the personal name Hilkiah "Yahweh is my portion" ( 2 Kgs 18:18; Isa 22:20; Jer 1:1; 29:3).82

The term may be used of a preordained lot in Hab 1:16 (food); Job 39:17 (wisdom), and more generally as the lot of individuals or nations in Job 20:29; Isa

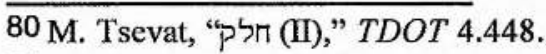

81 Von Rad, "The Promised Land and Yahweh's Land in the Hexateuch," ZDPV 66 (1943) 191-92, also in The Problem of the Hexateuch and Other Essays (Edinburgh and London: Oliver \& Boyd, 1966) 79-93, esp. 87.

82 Tsevat, "חלק (II)," 449-50 
$17: 14$; Jer 10:16. However, often this "lot" is brought about by the conduct of the recipient. As a rule, חל חל in the Hebrew Bible appears to be incompatible with the idea of determinism, or "fate." 83

Having given consideration to this background matter, Tsevat points out with some justification that Qohelet's usage of the term חלק is "peculiar to Ecclesiastes."84 Elsewhere in the Old Testament, it is unusual for God to be overtly made the subject of the action (though he may be the object). Exceptions to this rule occur in Deut $4: 19 ; 29: 25$ [26] in which Yahweh apportions other gods to the nations. However, nowhere in the Hebrew Bible other than in the book of Ecclesiastes does God appear to grant to the individual human being a "portion."

\section{(a) The Versions \\ (i) The Septuagint}

Of the 8 occurrences of the noun חוק in the book of Ecclesiastes, the LXX translates seven times with the term $\mu \in \rho i \varsigma(2: 10,21 ; 3: 22 ; 5: 17 ; 9: 6,9 ; 11: 2)$ and once by $\mu$ f́pos $(5: 18)$. Both of these terms have the basic meanings "part", "portion", "share", and thus serve as theologically neutral but nevertheless literal translations in keeping with the LXX's Aquilan character.

\section{(ii) The Vulgate}

Generally speaking, the same may also be said of the Vulgate which translates everywhere with the neutral term pars ("portion", "part"). However, in 2:21 it is striking that it renders חלק with the term quaesita ("acquisition", "gain"). In this case, the translator may be guilty of exegesis: if the contexts in which the term pars is used is considered, it would appear that it denotes either "portion" in a neutral 
sense $(11: 2)$, or in the sense of the rightful reward for one's labour $(2: 10 ; 3: 22 ; 5: 17$, $18 ; 9: 6,9)$. The term quaesita appears in the sense of a "portion" of which the individual is undeserving. This distinction may be intended to preserve the deity to some extent against accusations of injustice.

\section{(iii) The Targum}

The Targum translates the term חלק with its Aramaic cognate all locations. The passages in which the term occurs are subject to heavy midrashic interpretation, but do not provide any indication that the Targumist understood Qohelet to have a consistent system in his usage of the term. On the one hand, one's portion is allotted by the planets. Thus, the Targumist in 5:17 speaks of "the number of days of his life which the Lord gave to him by Fate for it is his portion" (מניין יומי חיוהי דגבר די יהב ליה י" במזליה ארום הוא חולקיה). Likewise in 9:9, the Targumist makes mention of "your vain life which the Lord gave you by Fate" (חיי הבלותך די יהב יי לך במזלא).

One's portion may have the sense of "duty, obligation" given by God in the present life in order that the recipient may receive a "complete reward" in the world to come. Thus in 2:10 the Targumist depicts Qohelet/Solomon labouring in the Torah and elucidating difficult points of religious law for the Sanhedrin. Qohelet then goes on to state "and this was my good portion which was allotted to me in order that I may obtain a complete reward in the world to come" ודין הוה דולקי טב ראודמן לי) (לקבלא עלוהי אגר שלים לעלמא דאתי The same interpretation of the term may be seen in Tg. Qoh 3:22.

One's reward after death is also termed "portion" by the Targumist. Thus in 9:6, he states concerning the wicked: "they no longer have a good portion with the righteous in the world to come" (וחולק טב לית להון עור עם צדוקוא לעלמא דאתי). Again, 
this particular interpretation of the meaning of חלק is also evident in Tg. Qoh 5:18. However, the term חולק is used in a more neutral sense in Tg. Qoh. 11:2 referring to the "portions" of seed to be sown in the seventh and eighth months and in Tg. Qoh 2:21 simply to what one has acquired in life (though once again this would be the result of Fate, or the planets, according to the Targumist's worldview).

The connection between חלק and the divine will for human beings is therefore made either explicitly or implicitly by the Targum in the majority of locations where it occurs in Ecclesiastes. Although the Targumist may read considerably more into Qohelet's usage of the term than the author of Ecclesiastes intended, he nevertheless demonstrates his understanding that one's "portion" is imposed from without. In this respect, he supports more modern views in which the deity is seen as responsible for the allocation of "portion" to human beings.

\section{(iv) The Peshitta}

The Peshitta translates the MT's חלק with redus in all locations. The term Rdu is a loanword derived from the Latin: moneta. As such, it is most often used in the financial sphere and has the basic meaning of "money" or "cash." A development from this meaning is the sense of "reward",85 which is most appropriate to the context of most its usages in Ecclesiastes.

Certainly, the use of the term redus cannot be said to offer a literal translation of the Hebrew r. However, it does have a semantic range broad enough to cope with both 2:10 where חלק may indeed be construed as "reward" and 2:21, in which חל may simply refer to the material goods acquired during one's lifetime (Cf. Vulgate). The term redus in the sense of "reward", may also carry the implication

85 Brockelman, Lexicon, 395. 
that one's חל may be allotted by God in exchange for labour.

\section{(b) Mediæval Jewish Exegesis}

The view of the Targumist, that Qohelet often uses the term חלק in the sense of something allotted to human beings by the deity, also finds expression in the work of some of the Mediæval Jewish commentators. Thus in 3:22, Rashi comments on the phrase כי הוא חלקו "The toil of his hands is the portion granted to him from Heaven, and by means of it he will rejoice" (גיע כפיו הוא החלק הניתן לו משמים ובו חישמי).

Rashi's position is to some extent contradicted by Metzudath David's comments on $5: 17 ; 9: 9$. In the former, he states, "all the wealth which God apportioned to him from above is his portion" (כל העושר הוא חלקו אשר חלק לו (אליה ממעל and in the latter, "in all the toil and all the labour you undertake in this world you have no portion...but this alone (enjoyment of life)" (בכל העמל והעורת (שאתה עמל בזה העולם אין לך חלק...רק זה לבד Although Rashi and Metzudath David agree that "portion" is granted by God, they disagree as to whether it consists of toil, wealth or enjoyment.

Metzudath David's implication in his comment on 9:9, that one's "portion" is a good which is limited in some way is also expressed in that of Ibn Ezra on 3:22, "There is no good but to rejoice in their lives, for there is no other portion for them" (אין שוב להם מאשר ישמחו בחיים כי אין להם חלק אחר). Likewise, Rashi commenting on 5:17 (and following Qohelet Rabbah) states that it is good for the individual "to engage in Torah....and he should not gather much wealth but rejoice in the portion granted to him, for it is his portion" (לעסוק בתורה...ואל יקבץ הון רב אלא בחלק הניתן לו ישממח כי היא חלקו Once more, Rashi understands the term Os a reference to toil (this time in the Torah). Nevertheless, the role of God in allotting this portion to the 
individual is highlighted, as well as the fact that this portion is of a limited nature.

Although some confusion therefore exists in the Mediæval sources, the term חלק is generally seen as referring to joy or wealth (Ibn Ezra, Metzudath David) or to some form of toil, whether physical or intellectual (Rashi).86 All commentators emphasise the divine origin of one's portion and also stress its limitations. In this respect, they anticipate the work of modern commentators.

\section{(c) Modern Commentators}

Crenshaw argues concerning Qohelet's use of the term חלק that "its essential meaning for him is limitation, a part of something rather than the whole thing. One's portion in life is the share of desirable or undesirable experiences which come along, not as the direct result of good or bad conduct but purely by chance." 87 Crenshaw's view here is a reasonable one, yet, as we have seen, what Crenshaw views as pure chance is often revealed to be something more akin to determinism. Few commentators indeed would argue that "portion" is a chance thing, for it is Godgiven as the lot of humanity.

Galling also sees "portion" as intimately linked with human life and ultimately defined by the deity. For him, it is "gerade zu terminus technicus für den der menschlichen Existenz zugeweisenen Raum."88 Not all locations in which חלק is used, however, permit Galling's general interpretation of it as "the space allotted to human existence", as Fox points out.89 Glasser in a footnote on 2:10, remarks on

\footnotetext{
86 Rashi also connects one's "portion" in this world and in the world to come with physical labour and Torah study respectively in his comment on 9:9 (following Eccl Rab. on 9:9).

87 Crenshaw, Ecclesiastes, 82. Crenshaw also gives expression to this idea of limitation in "The Eternal Gospel (Eccl 3:11)," in Essays in Old Testament Ethics (New York: Ktav, 1974) 48-49. In contrast, Whybray (Ecclesiastes, 55) emphasises the often positive nature of Ecclesiastes, lx, points out that any positive meaning of portion is limited strictly to this world.

88 Galling, Prediger, 89. Cited also by Tsevat, "חל (II)," 451. Most recently, Galling has been followed by Seow (Ecclesiastes, 151).

89 Fox, Qohelet and His Contradictions, 58.
} 
the resemblance of חלק to certain ideas of fate. For him, it is "le bonheur limité que Dieu distribue à sa guise aux hommes. On serait tenté de parler d'un 'lot', car le bonheur, constate Qohelet, est une loterie."90 This view approaches the definition offered by Crenshaw, whilst at the same time taking account of the deterministic nature of the term rin as we find in in Ecclesiastes.

Glasser's understanding of the term חלק as referring to "le bonheur limité" in 2:10 is well founded. The text in question states: "And whatsoever my eyes desired, I kept not from them. I did not withhold my heart from any joy, for my heart rejoiced in all my labour, and this was my portion (חלקי) of all my labour." It is noteworthy that in this verse, no overt reference is made to the material possessions which Qohelet has accumulated in the course of the "Royal Experiment."91 Rather, the subject of this verse is the joy which Qohelet has derived from his labour, emphasised by the repetition of Joy, rather than material possessions per se, is the due reward for Qohelet's hard work.92

This conception of חל הל is also reflected by Qohelet's words in 3:22: "So I saw that there is nothing better than that a person should rejoice in their own works, for that is his portion: for who shall bring him to see what shall be after him?" Here the "portion" of humankind, that they should rejoice in their labour, is reaffirmed. This is perhaps the only positive conclusion of Qohelet as a result of his search, yet it is also shown here to be a "second best" option. It is the alternative to the knowledge of existence which Qohelet seeks: the ability "to see what shall be after him." This therefore illustrates the definition of חלק as the "limited good" of which

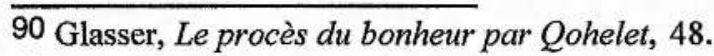

91 It could be argued that here the term עמל refers to "goods obtained by labour" rather than labour itself (so Fox, Qohelet and His Contradictions, 181). If so, however, this would only emphasize the position of joy as "my portion from all my עמל."

92 Delitzsch, Ecclesiastes, 242-3. 
both Crenshaw and Glasser speak.93

Again, in 5:17 (Eng. 18) the same link between joy and "portion" is made by Qohelet: "Behold what I have seen: it is good and comely to eat and to drink, and to enjoy the good of all his labour which one takes under the sun all the days of his life which God has given him, for it is his portion." In this passage, the term חלק specifically pinned down as "the enjoyment of the good in one's labour." It is also, perhaps, worthy of note that the term יפה is used to describe the taking of one's portion, the only other occurrence outside $3: 11$ in which it is used to describe the irresistible nature of Fate.94 The theme of "portion" as joy is made more explicit still in 5:18 (Eng. 19), where "to rejoice in one's labour" (לשמאח בעמלו) is parallel to the phrase "to take one's portion" (לשאת את חלקו).

The Sitz im Leben of the term therefore appears to be in the realm of human emotions.95 This is also reflected in 9:6, in which Qohelet considers the situation of those who have died: "Their love, their hatred and their envy are now perished; neither have they any more a portion forever in anything which is done under the sun." Thus far, the term "portion" has been considered merely as "joy" in one's labour or the benefits derived therefrom. In this verse however, "portion" appears also to designate any human emotion. "love" and "hatred" certainly appear in the list of predetermined actions and emotions in 3:1-8.96 "Envy" is intimately bound up with human toil in $4: 4$; so much so that it appears almost as if human progress is ultimately little more than a beneficial by-product of rivalry. Likewise in

93 Crenshaw, Ecclesiastes, 82; Glasser, Le procès du bonheur par Qohelet, 48. Delitzsch (Ibid., 272) describes portion in the sense of joy as "the best which (man) has of life in this world."

94 Murphy, who to some extent understands $3: 1-11$ as a deterministic text, notes a parallel between God making an action "beautiful in its time" (פה בעתו) in 3:11 and the characterisation of portion as "beautiful" in 5:18 (Eng. 19) (Ecclesiastes, 32-35, 53). In actual fact however, it it the action of taking one's portion that is "beautiful."

95 That such may be the case is partly suggested by Fox (Qohelet and His Contradictions, 59).

96 As I argue in a forthcoming article, love is an emotion which is conditioned by the deity ("Woman as Divine Agent in Ecclesiastes," 418-19, 421). 
9:9, the admonition to "experience life with the woman you love" is backed up by

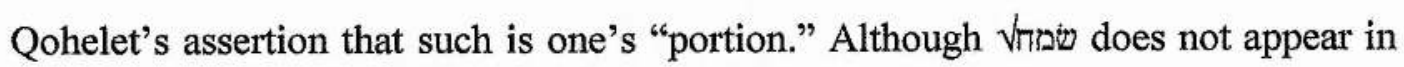
this verse, the verb אהב does. Once again, the location of the term "portion" is to be found firmly in the realm of human emotions.

Apart from the neutral use of the term $11: 2$ (in which the giver of a portion is clearly intended to be the reader), the only significant departure from Qohelet's usage of one whose earnings were acquired by wisdom and by knowledge and by skill;97 yet he must give them as his portion to one who has not toiled for them (Cf. 2:22)."98 Even here, the "portion" to which Qohelet refers might well be the pleasure arising from the use of the wealth accrued by the first man. 99

\section{(d) Conclusion}

To conclude then: Qohelet uses the term חלק in a way fundamentally different to its usage elsewhere in the Hebrew Bible. It is something which is given by God, and one can say with Crenshaw that it is indeed a "limited good" which is allotted to humankind in life. Being as it is a gift, it has little or nothing to do with the individual merit of the recipient. It may be granted freely or withheld, even transferred to another, at God's discretion (cf. 2:21-26).100 The term 5 m refers to human emotions, primarily to the enjoyment of life. However, Eccl 9:6 suggests that חלק may apply in fact to the whole range of human emotions. Some evidence for this view is also provided by 9:9, where one's portion is to love a woman. Although חלק cannot be defined as "Fate", it is a concept which illustrates the deterministic nature

97 Translating the term כשרון as "skill" with Whitley (Koheleth: His Language and Thought, 27).

98 Understanding חלקו as a predicate accusative with Hertzberg (Der Prediger, 80) and Podechard (L'Ecclésiaste, 277-78).

99 So Crenshaw (Ecclesiastes, 88), who sums up the mood of the verse: "I earned the wages and therefore am entitled to derive satisfaction from them."

100 Cf. Whybray ("Qoheleth, Preacher of Joy," 89). 
of Qohelet's worldview. If human feelings are subject to the will of God, then the whole concept of human free will is called into question. 


\section{Chapter 3 \\ "A Time to Give Birth, A Time to Die": \\ A Response to Blenkinsopp}

\section{Introduction}

Ecclesiastes 3:1-15 is a key text for our understanding of Qohelet's thought. Unfortunately, as we have seen, it lends itself to a variety of interpretations. Until very recently commentators were divided into two camps as to the intent of this passage. While some see the text as enumerating a variety of "ideal" times for human activities which human beings are unable to, or prevented from, achieving, 1 others have argued that Qohelet is advancing the thesis of determinism.2 Despite objections that several passages in Ecclesiastes presuppose a degree of free will, the reasonably wide acceptance which the deterministic understanding of this passage enjoys is partly due to the fact that the first two actions cited in 3:2: עת ללדת ועת למות, translated by RSV, NRSV, NEB, NAB and many commentators "a time to be born, a time to die", are not generally recognised as being under human control. ${ }^{3}$

In a recent article, Joseph Blenkinsopp has presented a series of arguments which call into question the legitimacy of this deterministic reading. His thesis is that Ecclesiastes 3:2-8 represents a quotation from a Stoicizing Jewish sage to which Qohelet prefaces a title $(3: 1)$ and a commentary refuting the content of this quotation

\footnotetext{
1 Plumptre, Ecclesiastes, 126-131; Whybray, Ecclesiastes, 67.

2 Delitzsch, Ecclesiastes, 255; Gordis, Koheleth: The Man and His World, 229; Murphy, Ecclesiastes, 33.

3 Delitzsch, Ecclesiastes, 256; Zimmerli, Der Prediger, 162; Scott, Proverbs Ecclesiastes, 220-21;

Fox, Qohelet and His Contradictions, 190, 192. The determined nature of "time" is also implicit in Loader's understanding of the actions in 3:2-8 as "desrirable" or "undesirable" ("Qohelet 3:2-8-A

'Sonnet' in the Old Testament," ZAW 81 (1969) 240-42).
} 
$(3: 9-15) .4$ The observation that $3: 2-8$ may be an extended quotation is not new. 5 Previous commentators have also suggested that it expresses the Stoic ideal of living according to nature. 6 Where Blenkinsopp diverges from earlier interpretations of this passage is in the suggestion that Qohelet specifically argues against the content of this passage in $3: 9-15.7$ It is to this question there that attention shall first be directed.

\section{Text and Context}

The argument that $3: 2-8$ is most likely a quotation, rather than original to Qohelet, rests on two foundations. The first is that the language of this passage finds little or no echo in the rest of the book of Ecclesiastes. The second is that the idea of the passage does not reflect Qohelet's thinking elsewhere in Ecclesiastes. 8 The former issue is one with which it is relatively simple to deal. The second is more difficult: there is no consensus as to the intent of $3: 2-8$. Its relationship (or not) to the rest of Qohelet's work is therefore entirely dependent on how the individual commentator reads the passage.

Blenkinsopp does not state outright his reasons for rejecting the idea that 3:28 advances a deterministic thesis. It cannot be that he rejects determinism in Ecclesiastes generally, for he argues that Qohelet puts forward this idea in 3:9-15 to counter the content of $3: 2-8.9$ The problem appears to lie in the extent to which

\footnotetext{
4 Blenkinsopp, "Ecclesiastes 3:1-15: Another Interpretation," 55-64.

5 A. G. Wright, "'For Everything There is a Season': The Structure and Meaning of the Fourteen Opposites (Ecclesiastes 3, 2-8)," in J. Doré et al.(eds.), De la Tôrah au Messie. Mélanges Henri Cazelles (Paris: Gabalda, 1981) 321-28; Whybray, Ecclesiastes, 69-70; Murphy, Ecclesiastes, 33.

6 Tyler, Ecclesiastes, 13; Gammie, "Stoicism and Anti-Stoicism in Qoheleth," 175.

7 Whybray (Ecclesiastes, 69-70, 72) comes close to suggesting that Qohelet argues against the content of 3:2-8 in 3:9-15 when he hypothesizes that Qohelet reinterprets the passage which he has just quoted. Cf. also W. J. Fuerst, The Books of Ruth, Esther, Ecclesiastes, the Song of Songs, Lamentations (Cambridge: C.U.P., 1975) 113.

8 Whybray, Ibid., 70; Blenkinsopp, "Ecclesiastes 3.1-15: Another Interpretation," 57.

9 Blenkinsopp, Ibid., 61-63.
} 
reading 3:2-8 deterministically would subordinate human free will to the control of the deity.10 Thus Blenkinsopp accepts a form of determinism in which God predisposes events to happen, while leaving humanity free to make the choice of how they respond to these events. This viewpoint is not without precedent in the work of Chrysippus (although it is a fundamentally illogical one, since all events presumably need human beings to enact them). Before considering the thought of this passage and its relation to the rest of Ecclesiastes, however, it is as well to to consider the language of 3:2-8.

\section{(a) The Language of 3:2-8}

Although Blenkinsopp argues that the language of $3: 2-8$ is not characteristic of Qohelet, a closer study shows that this is not, in fact, the case. Purely on a lexical basis one can point to the fact that the word עת "appointed time", whilst it occurs 29 times in $3: 2-8$, is used a further 11 times outside this passage $(3: 11,17 ; 7: 17 ; 8: 5,6$, 9; 9:8, 11, 12 [twice]; 10:17). The use of the term strictly part of the passage according to Blenkinsopp, nevertheless summarises Qohelet's understanding of it, finds its echo in the 7 uses of $\downarrow \gamma$ m in $3: 17 ; 5: 3,7 ; 8: 3$, $6 ; 12: 1,10$. Although four of these citations occur in a different context of desire or pleasure (and as such translated in the LXX by the verb $\theta$ é $\lambda \omega$ [8:3] or the related noun $\theta \in \dot{\epsilon} \lambda \mu \alpha[5: 3 ; 12: 1,10]), 11$ the usages in $3: 17 ; 5: 7 ; 8: 6$ retain the same sense as that in 3:1.12 Indeed in 3:17 and 8:6 Qohelet repeats a variation of the basic phrase in 3:1 that "there is an appointed time for every purpose" (עיץ לכל חפץ). While not all of the actions in 3:2-8 feature elsewhere in the book of Ecclesiastes, a significant

10 This also seems evident in the work of Gammie ("Stoicism and Anti-Stoicism in Qoheleth," 175), for he understands some actions as illustrative of Stoic determinism, and others as illustrative of free will. Similar is Levine ("The Humor in Qohelet," $Z A W 109$ [1997] 78-79) who also undestands 3:2-8 as a text emphasising the Stoic ideal of living according to nature.

11 W. Staples, "The meaning of hepe sin Ecclesiastes," JNES 24 (1965) 110-12.

12 Blenkinsopp himself points out this fact ("Ecclesiastes 3.1-15: Another Interpretation," 60). 
proportion do. The verb ילד occurs 4 times outside our passage $(4: 14 ; 5: 13 ; 6: 3 ; 7: 1)$ whilst the verb מות occurs 8 times (2:16;4:2 [twice]; 7:17;9:3, 4, 5 and the noun 6 times (3:19 [twice]; 7:1, 26;8:8; 10:1). The verb נטע occurs outside this passage 3 times $(2: 4 ; 2: 5 ; 12: 11)$, whilst the verbs פרץ occurs in 10:8 and $2: 4 ; 9: 14$. More significantly, שמש is used 4 times outside this passage $(2: 2 ; 7: 3,6 ; 10: 19)$. The verbs ספוד occur in 12:5 and כ2:8,26, whilst the verbs כבוס occur in 4:5 and in 12:6. The verb בקש is more frequent in Ecclesiastes with 6 occurrences outwith this passage $(3: 15 ; 7: 25,28,29 ; 8: 17 ; 12: 10)$ and verbal forms of $\sqrt{7}_{7}$ occurring 5 times $(5: 13 ; 7: 7,15 ; 9: 6,18)$. The verb שמר is repeated 8 times outside this passage $(4: 17$; $5: 7,12 ; 8: 2,5 ; 11: 4 ; 12: 3,13)$. The verb רבר occurs in $1: 8,16 ; 3: 7 ; 7: 21$ with the derived noun דָרָ occurring a total of 24 times. The verb אהב occurs in 5:9 [twice]; 9:9 and its derived noun שהבא 9:1, 6, whilst its opposite (2:17, 18) with its derived noun also in 9:1, 6. Finally, the noun מלחמה occurs twice outside this passage $(8: 8 ; 9: 11)$.

\section{(b) The Ideas of 3:2-8}

There seems little reason not to suppose on a lexical basis that Qohelet might have written this passage. While none of the terms contained therein are unique to Qohelet, he nevertheless uses most of them on a regular basis throughout Ecclesiastes. However, Blenkinsopp's arguments concerning the meaning of 3:2-8 also demand closer examination. Blenkinsopp rightly points out the fact that the infinitive in עת ללדת in 3:2 is Qal and therefore has an active sense (i.e., it should be best translated "a time to give birth"). Where Qohelet does speak of "being born", he follows standard Hebrew usage with a Niphal form, as in 7:1 the ויום המות מיום הולדו 
day of death (is better) than the day of birth."13 Blenkinsopp's translation of $3: 2$ is

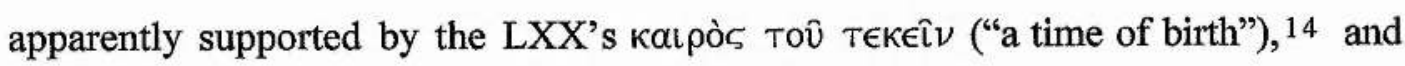
by the Targum's עידן בחיר למילד בנין ועידן בחיר לקטלא בנין מסרבין ומרגזין לקטלותהון "A time chosen to bear sons and a time chosen to kill rebellious and blaspheming sons, to kill them with stones by order of the judges"). This reading is also supported by the Peshitta's a darime ("a to bear"), although the Vulgate's tempus nascendi ("a time to be born") has attempted to harmonize with עת למות by rendering the phrase in a passive sense.

Since the phrase עת ללדת is active and to be translated "a time to give birth", this, claims Blenkinsopp, leaves the expression, עת למות "a time to die", as the only one of 28 human actions or events not under human control. The context of the passage therefore demands an interpretation of למות in which human beings choose to die. Thus, it may be explained as an exhortation to suicide in line with contemporary Stoic thought.

It is true that there seems to have been no prohibition in Jewish law against suicide.15 One could therefore understand (as Blenkinsopp does) עמת למות as referring to the rational, planned suicide of the Stoic sage. Can its opposite, however, giving birth, really be said to be an activity under human control? Blenkinsopp's statement that "it...makes sense to speak of deciding to have a child and choosing the best time to do it"16 essentially understands $3: 2$ as a text extolling the virtues not only of euthanasia, but also of of family planning: yet, children are never depicted in the

13 Ibid., 56-57. Blenkinsopp follows in a line of commentators including Tyler, Ecclesiastes, 124; Podechard, l'Ecclésiaste, 286-87; Glasser, Le procès du bonheur par Qohelet, 58-59; Crenshaw, Ecclesiastes, 91, 93; Murphy, Ecclesiastes, 28-29.

14 The Arabic version of Ecclesiastes, dependent on the LXX, translates waqt lilwilada ("a time for childbearing").

15 A. J. Droge \& J. D. Tabor, A Noble Death: Suicide and Martyrdom among Jews and Christians in Antiquity (San Francisco: Harper-Collins, 1992), 53-84; cf. Droge, "Suicide," in ABD 6.227-30. The idea that למות may refer to suicide is mentioned but rejected by Plumptre (Ecclesiastes, 127). 16 Blenkinsopp, "Ecclesiastes 3.1-15: Another Interpretation," 60. 
Hebrew Bible as anything other than a blessing. 17 On a strictly literal level, moreover, the time at which one gives birth once pregnant is something over which the individual has no control:18 Qohelet indeed speaks of the "untimely birth" (-6:3) in a passage that vividly illustrates the inability of human beings to find happiness by their own efforts.

Whether Stoic or no, it would in fact be rather strange if a Jewish sage claimed that human beings had control over either birth or death. Not only do these two actions encompass the whole of human life, 19 they are also the two single actions that an ordinary Jew could accept without hesitation to be in the hands of God rather than those of humanity.

As an illustration of this, God is often said in the Hebrew Bible to "give" or to "add" a son (Gen 17:16; 29:33; 30:6, 24; 1 Kgs 3:6; 5:7; Isa 9:6), cf. Gen 4:1; Judg

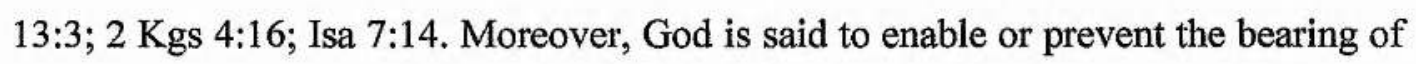
children by opening or closing the womb (Gen $20: 18 ; 29: 31 ; 30: 22 ; 1$ Sam 1:5), indeed the role of God was essential in the creation of new life since he formed it in the womb and brought it forth from there (Job 10:18; 31:15; Isa 44:2; 66:8). Qohelet himself in Eccl 11:5 compares the "way of the spirit" and the formation of the foetus in the womb to "the works of God who makes everything." Conversely, Qohelet also speaks in Eccl 12:7 of God's role at the moment of death when "the spirit returns to God who gave it." Human beings are arbiters neither of the time of conception, nor or birth: these mysteries are firmly in the control of God.

Likewise, the Qal of מות is often used of death inflicted by God in the Hebrew Bible (albeit as a penalty for disobedience or sin): Gen $3: 3 ; 20: 3,19$; Ex 11:5;

\footnotetext{
17 J. A. Grassi, "Child, Children," in $A B D$ 1.904-5.

18 Tyler (Ecclesiastes, 124) took עת ללדת to refer to the nine-month period of gestation in human beings, indicative of the general law of Nature rather than of a determinism which applies to individuals.

19 Crenshaw, Ecclesiastes, 93; Murphy, Ecclesiastes, 33.
} 
$12: 33 ; 28: 35 ; 30: 22 ;$ Lev $8: 35 ; 10: 2,6,7,9 ; 16: 1,2,13$; Num $3: 4 ; 4: 19,20 ; 14: 35$; $17: 14,28,35 ; 18: 3,32 ; 26: 11,61$; Deut 5:22; 18:16; Josh 10:11; Judg 6:23; 1 Sam $5: 12 ; 12: 19 ; 25: 17,38,39 ; 2$ Sam $6: 7 ; 12: 13 ; 1$ Kgs $19: 4 ; 2$ Kgs $14: 6=2$ Chr $25: 4 ; 1$ Chr 24:2; 2 Chr 13:20; 2 Kgs 19:35=Isa 37:36; Ezek 3:20; 18:4, 20, 21, 28; 33:15. The specific expression מות ימות occurs in Gen 2:17; 3:4; 20:7; Num 26:65 Judg $13: 21,22 ; 2$ Sam $12: 14 ; 14: 14 ; 2$ Kgs $1: 4,6,16$; Ezek $3: 18 ; 33: 8,14$. Naturally these may be argued to be exceptions, examples in which God cuts short life for a specific act on the part of the sinner. One might also argue on this basis that God has very little to do with determining the time of death under normal circumstances, and moreover that none of the texts cited above have very much to do with the wisdom tradition of which Qohelet was a part. However, the determination of the time of one's death by God is a question expressly considered by the wisdom tradition: for whilst those who follow the path of the simple are promised an early death, those who follow the dictates of wisdom are said simultaneously to enjoy "length of days, long life and peace" (Prov 3:2) and "favour and good understanding in the sight of the Lord" (Prov 3:4). Likewise, personified Wisdom is said to offer "length of days in her right hand, and in her left hand riches and honour" (Prov 3:16) and states that "whoever finds me finds life" (Prov 8:35). Implicit in Eccl 7:17 is the idea that it is God who determines the time (ע) of one's death, and God who can change this time if he so wills. For the Israelite therefore, there was no theoretical problem in accepting a limited form of determinism, so long as it was emphasised that this determinism was God-driven rather than simply an impersonal irrational force. The appeal of Stoicism for some thinking Jews lay precisely in the fact that it identified God (i.e. Zeus) and the deterministic mechanism controlling the universe as one and the same. 20

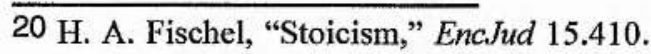


The location of these two actions, birth and death, at the head of the list in 3:2-8 seems therefore rather to be intended as a preparation for what comes after. In other words, acceptance that birth and death are in the hands of God paves the way for the acceptance of the idea that all other events and actions on earth are likewise in the hands of God. This is further underlined by the last pair of opposites, "a time of war, a time of peace" (3:8) which have also attracted attention from commentators. 21 No human action whatsoever is implied here: Qohelet does not claim that there is "a time to make war, a time to make peace." Again, these are also actions which any Jew would have accepted without question to be within God's power ( 2 Kgs 24:2; 1 Chr 5:22; 22:9; Hag 2:9). The predetermined actions and emotions in human life which might be more questionable to a Jew are sandwiched between these two absolutes. They serve as the sugar coating to the bitter pill of determinism.

\section{(c) The Thought of 3:9-15}

What is the relationship between $3: 1-8$ and the thought of 3:9-15 immediately following? Having effectively argued against a deterministic reading of the former, Blenkinsopp suggests that $3: 9-15$ is intended to refute the thesis of $3: 2-8$ that everything has its appropriate time, in accordance with which human beings can act.22 In many ways, this suggestion owes something to the work of commentators such as Tyler and Lohfink, who have argued that Qohelet makes use of the Stoic diatribe.23 The similarity with the work of Whybray, who has suggested that some portions of Ecclesiastes contain quotations which Qohelet subsequently refutes, is

\footnotetext{
21 Jastrow (A Gentle Cynic, 209-10 n. 40) in fact deletes all of 3:3-8. However, Delitzsch sees as significant the fact that the list of activities ends in "peace" (Ecclesiastes, 259), and Crenshaw (Ecclesiastes, 96) suggests that the change in syntax and structure in 3:8 allows the poem to come to a forceful conclusion.

22 Blenkinsopp, "Ecclesiastes 3.1-15: Another Interpretation," 59, 61.

23 Tyler, Ecclesiastes, 48; Lohfink, Kohelet, 10.
} 
even more pronounced.24 To this extent, the thought of 3:9-15 will now be considered with reference to the preceding section.

\section{(i) $\underline{3: 9-10}$}

Generally speaking, commentators seem to be somewhat puzzled by Qohelet's introductory question in 3:9, "What profit has the worker at that wherein he labours?" Several suggestions as to the interpretation of this verse in the light of 3:1-8 have been offered. Murphy argues that the rhetorical question, essentially a restatement of $1: 3$, judges human activity as profitless because it cannot change what God has determined.25 This is possible from the immediate context, but why should Qohelet advocate that God's work be changed? Qohelet's ambitions seem directed rather at finding "the work of God/the work which is done under the sun" (3:11; 8:17). Conversely, Whybray (followed by Blenkinsopp) suggests that activity is profitless because human beings are unable to act at the appropriate moment which God has determined for each work. 26 One could certainly argue that this would make human activity profitless for God, but whether it is so for human beings is less clear: implicit in Qohelet's question in 1:3; 3:9 is the idea that there is no profit for humanity in any activity. This is despite the fact that some actions (e.g. joy/toil [2:26]; love [9:9]) are explicitly stated to be determined by God (and hence would occur at the "appropriate time" according to Whybray and Blenkinsopp's understanding of $3: 2-8)$.

Crenshaw's interpretation is that human activity is profitless because each opposite in 3:2-8 cancels the other out: labour thus produces nothing in the long

\footnotetext{
24 Whybray, Ecclesiastes (OTG; Sheffield: JSOT, 1989) 35-40. This view was also to some extent advanced by Gordis (Koheleth: The Man and His World, 95-108).

25 Murphy, Ecclesiastes, 34.

26 Whybray, Ecclesiastes, 72-73; Blenkinsopp, "Ecclesiastes 3.1-15: Another Interpretation," 61. Broadly similar is the approach of Plumptre (Ecclesiastes, 131) and Podechard (L'Ecclésiaste, 291).
} 
term.27 One could perhaps argue this for humanity as a whole, but not for the individual. Thus, Delitzsch's suggestion seems best to fit the context: Qohelet's claim is that activity is without profit for human beings because everything is determined by God as 3:1-8 implies. 28

This viewpoint may be illustrated with the hypothetical case of a slave working on the estate of a large landowner. The slave is not an autonomous being in his own right, but a tool, an extension of the master's will. The actions of the slave are entirely determined by the will of this master and works not for himself but for another. Well might this slave ask himself "what benefit do I get from all my work?"

Such is the situation in which humanity finds itself in a world where all human activity is determined by an inscrutable deity: this interpretation is supported moreover in 3:10, in which Qohelet states: "I have seen the toil (ענין) which God has given to humanity to be occupied with." The overall in life in 3:10 is reflected by the times and seasons determined by God for every human action, thought and emotion in 3:1-8 - but Qohelet has not merely seen this divinely determined toil, he has shown it to the reader.

\section{(ii) $\underline{3: 11}$}

The exegesis of 3:11 has already been discussed in some depth in Chapter 2 of this thesis. The theme of determinism evident in $3: 1-8$ and continued in $3: 9-10$ supports the reading given therein, that the phrase "he (i.e. God) has made everything beautiful in its time" refers to the irresistible nature of the times determined by God. To put it another way: human beings have no choice or control over the actions which they perform: they are simply drawn to act when and how

\footnotetext{
27 Crenshaw, Ecclesiastes, 96.

28 Delitzsch, Ecclesiastes, 259. Followed to some extent by Barton (Ecclesiastes, 101).
} 
God wills. 29

Murphy, following Podechard, is most likely correct in his assessment of the phrase, "God has put העלם in their (i.e. humanity's) minds" as referring to God's placing of an eternity of times in human minds. 30 This too ties the verse in with the deterministic context of $3: 1-8$, for העלם is the whole of which each individual is a part: thus Qohelet envisions God programming humanity with all the actions which they will perform in their lives. Since it is this עלם controls human action, the action of placing it in the human mind thereby ensures that "humankind may not find out the work of God from beginning to end."

It is perhaps significant that Blenkinsopp gives little consideration of this verse, which, after all, is crucial in the interpretation of the preceding catalogue of seasons. Apparently, he understands the expression יפה בעתו in the sense "appropriate to its time": that is, while God makes everything happen, the proper fulfilment of the activities listed in 3:2-8 (and presumably the success of the overall divine plan for the world) are dependent solely on humanity's ability to determine these times and to act in accordance with them. Yet no clear explanation is given for $3: 11 \mathrm{~b}$ which ought to provide further evidence for this view: human beings, according to Blenkinsopp, lack the knowledge to align their actions with the divine activity (understanding העלם as "ignorance"?).31 Yet what of God's role and its implications? If the divine plan requires human beings to act in accordance with the "times" which he has set, why does he deprive human beings of the necessary knowledge to do so (for it is God who places העלם in human minds)? Another difficulty with this view is that Qohelet clearly uses the phrase לעלם in 3:14 in the sense of "eternal", potentially undermining Blenkinsopp's understanding of the meaning of this term in

\footnotetext{
29 Fox, Qohelet and his Contradictions, 193.

30 Murphy, Ecclesiastes, 34; Podechard, L'Ecclésiaste, 295.

31 Blenkinsopp, "Ecclesiastes 3.1-15: Another Interpretation," 59, 61.
} 
$3: 11$,

(iii) $\underline{3: 12-13}$

A full discussion of the implications of Qohelet's recommendation to joy may be found in Chapter 7 of this thesis. For now, however, it is worth giving consideration to these verses in the light of Qohelet's advocacy of a deterministic God. Firstly, Qohelet's comment in 3:12, "I know that there is no good for them (ב) except to rejoice and to fare well in life", may require emendation, and indeed some commentators follow BHS and emend באדם thanslating: "I know that there is no good for humankind but to rejoice...") in order to provide an antecedent for the pronominal suffix on ${ }^{-}$. .32 With this position I, tentatively, concur. Qohelet appears to comment that the only good actions (which I take to mean the only activities over which human beings have some form of control) among the "all" of 3:1 which God determines are "to rejoice" (לשמוח) and similarly, "to fare well" (טוב לעשות) (note the infinitives, which pick up on and extend the range of those of $3: 2-8$ ). Unfortunately, the ability to do even this much is determined by God, for it is termed by Qohelet in 3:13 "the gift of God" (מחר אלהים) that one may "eat and drink and experience good in all one's labour (עמלו)."33 Again, the term עמלו picks up on the participial form עָָמָל in Qohelet's rhetorical question in 3:9. There is no clear profit (יתרון) in labour, but there is some good (טוב). ${ }^{34}$ This, however, is entirely subject the the goodwill of the deity.

$$
\text { (iv) } \underline{3: 14-15}
$$

32 Among those who emend are Podechard (L'Ecclésiaste, 296-97); Zimmerli (Der Prediger, 163), Fox (Qohelet and his Contradictions, 194). Others explain by referring the plural suffix back to באדם in the preceding verse (Murphy, Ecclesiastes, 30; Whybray, Ecclesiastes, 74).

33 Glasser, Le procès du bonheur par Qohelet, 65; Whybray, "Qoheleth, Preacher of Joy," 89-90.

34 Whybray (Ecclesiastes, 74) lays particular emphasis on the threefold repetition of the term 3:12-13. 
The conclusions which Qohelet draws from the fact of determinism in 3:1213 (that the only good activities are to eat, drink and enjoy life, but that even this much is dependent on the deity) are heralded by his use of the phrase "דעתי כי (I know that"). In 3:14, Qohelet makes another point introduced by this phrase: "I know that all which God does is eternal: there is no adding to it, nor is there any taking away from it." Murphy notes the unusual nature of Qohelet's comment on the immutability of the divine deed as opposed to the divine word here, 35 but לעלם Qhelet does not mean that the results of God's actions lasts forever. Nor does mean that God's actions cannot be changed by human beings (though Qohelet would certainly agree that God's actions are unchangeable). ${ }^{36}$ The text states that human beings cannot add to or take away from what God does. In the context of determinism this would mean that human beings cannot add to God's work by acting under their own initiative, nor subtract from it by refusing to perform the actions which God has allotted them. By making all human activity dependent on himself, God ensures respect from humanity (שיראו מלפניו).37

This deterministic reading of $3: 14$ is in fact supported by Blenkinsopp, although it is not necessary to posit the idea of written "tablets of destiny" for individuals to make sense of Qohelet's words therein. 38 Yet if one cannot add to or take away from God's work, what are we to make of the all-embracing advocacy of human free will which underlies Qohelet's supposed quotation of 3:2-8? His reading of 3:11 underlines the ability of human beings to make the divine plan go awry (albeit unintentionally), since they are unable through lack of knowledge to fulfil their part

35 Murphy, Ecclesiastes, 35.

36 Delitzsch, Ecclesiastes, 263; Crenshaw, Ecclesiastes, 99.

37 This understanding is not far removed from that of Glasser (Le procès du bonheur par Qohelet, 65) who suggests the meaning "définitif" for לעלם. Similar is Fox (Qohelet and His Contradictions, 195), who says that Qohelet means to express the idea that "it is always the case that what happens is only what God has made happen."

38 Blenkinsopp, "Ecclesiastes 3.1-15: Another Interpretation," 62. 
in the divine plan: how then can God's work be "eternal" (or indeed, find any expression whatsoever)?

The idea that Qohelet offers a deterministic commentary on the text of 3:2-8 finds further support in the next verse: "What is has already been, and what is to be already is. God seeks out the pursued." Human beings are unable to change the course of events in the world by their own initiative: all is controlled by God. Whatever the meaning of the difficult phrase ודאלהים מבקש את נרדף (and most commentators take it as illustrative of God's control over history as a whole), the section 3:14-15 would appear to reiterate the deterministic theme which is evident in the catalogue of times and seasons and the commentary which Qohelet offers on it.39

\section{(v) Concluding Remarks on 3:9-15}

Thus far, this chapter has sought to demonstrate that $3: 1-15$ can be read as a unity, with determinism the central linking theme between the two subsections $3: 1-8$ and 3:9-15, of which it is composed. Yet the fact that 3:1-15 can be read in this way does not necessarily mean that it should be read thus, or that Qohelet's intent was that it should be read thus.

As we have seen, Blenkinsopp's reading of 3:1-15 creates as many problems as it seeks to solve. The simplest solution, that $3: 1-8$ reflects a deterministic worldview severely limiting human free will, and that Qohelet offers a positive commentary upon this in 3:9-15, offers a logical development of thought in the passage. As shall be demonstrated presently, moreover, considerations arising from an examination of the wider context of Qohelet's thought in Ecclesiastes also supports this interpretation and contradicts that of Blenkinsopp.

39 e.g. McNeile, An Introduction to Ecclesiastes, 63; Barton, Ecclesiastes, 102-3; Gordis, Koheleth: The Man and His World, 233-34. Cf. Salters ("A Note on the Exegesis of Ecclesiastes $315 \mathrm{~b}$," $\mathrm{ZAW}$ 88 [1976] 419-20) for the history of interpretation of this difficult passage. 


\section{The Wider Context}

Blenkinsopp's understanding of Eccl 3:1-15 does not rest entirely on internal evidence from the passage itself, but also on the wider context of Qohelet's thought. This section will therefore consider whether this extra evidence truly supports the thesis that Qohelet engages in a dialogue in 3:1-15 about human attempts "to live according to nature", or whether it supports the thesis that $3: 1-8$ is expressive of God's imposition of his "times" on humanity.

\section{(a) Time and Judgement $(3: 17 ; 8: 5-6)$}

Blenkinsopp in fact argues that the whole of 3:9-22 serves as Qohelet's commentary on the catalogue of times and seasons but restricts his article to an examination of the passage 3:9-15.40 This response has been similar restricted so far, but it is at this point that Qohelet's connection between "time" (עת) and judgement ( (שפ $)(3: 17 ; 8: 5-6)$ will come into consideration. Blenkinsopp briefly considers both passages in which the phrase occurs: on $3: 17$, he remarks "the allusion in 3:17 to the time appointed for every matter and work, in this case the punishment of the wicked, suggests that vv. 16-22 are also part of the commentary on the poem." 41

There is good reason for Blenkinsopp's claim here. The text of 3:17 states: אמרתי אני בלבי את צדיק ואת הרשש ישפט האלהים כי עת לכל חפץ ועל כל מעשה שם to myself, 'God will judge the righteous and the wicked, for there is a time for every business and for every work there." Of particular interest are two aspects of this passage.

Firstly, the phrase עת לכל חפץ ועל כל מעשה שם in 3:17 clearly echoes the comment לכל זמן ועת לכל חפיץ תחת השמים which Qohelet made earlier in 3:1 (accepted

\footnotetext{
40 Blenkinsopp, "Ecclesiastes 3.1-15: Another Interpretation," 57.

$41 \mathrm{Ibid}$. By way of contrast, Crenshaw ("The Eternal Gospel," 25), sees the unit as ending in 3:15 and thus understands $3: 16-4: 3$ as a separate unit.
} 
by Blenkinsopp as a title outlining Qohelet's understanding of the times and seasons in $3: 2-8) .42$ Secondly, the fact that "there is an (appointed) time for every business" is given as a reason for Qohelet's statement that God will judge the righteous and the wicked.

This creates a serious problem for Blenkinsopp's reading of 3:2-8 (and indeed, that of any commentator who understands the passage as an expression of the Wisdom belief in an "ideal" time for human action). For if it is God who acts at the "appointed time" in $3: 17$, surely it is also God whose action (through human beings) is being catalogued in 3:1-8.43 Moreover, it is "the work of God" which is the putative subject of human investigation in $3: 11$.

Blenkinsopp also considers briefly Eccl 8:5-6 in this context: here Qohelet links the two concepts of "time" and "judgement" more overtly. Blenkinsopp adopts the position that in 8:5, the phrase עח ומשפט לב חכם ("the heart of the wise man knows time and judgement") refers to the ability of the wise man to tailor his actions to act at the appropriate time. In a courtly context, such as we find in $8: 2-6$, this may appear a not unreasonable understanding. 44 However, Blenkinsopp has suggested in 3:9-15 that human beings are unable to act in accordance with "time." 45 Thus, one must argue that the wise mind in $8: 5$ is an exception to the general rule, or that simply another of those contradictions which some commentators see in Qohelet's work.

However, in Chapter 2, I have argued that Qohelet introduces this section in 8:2 with a reference to the special status of the king with respect to God: Qohelet adjures loyalty to the king on the basis of "the oath of God" (which I take to be the

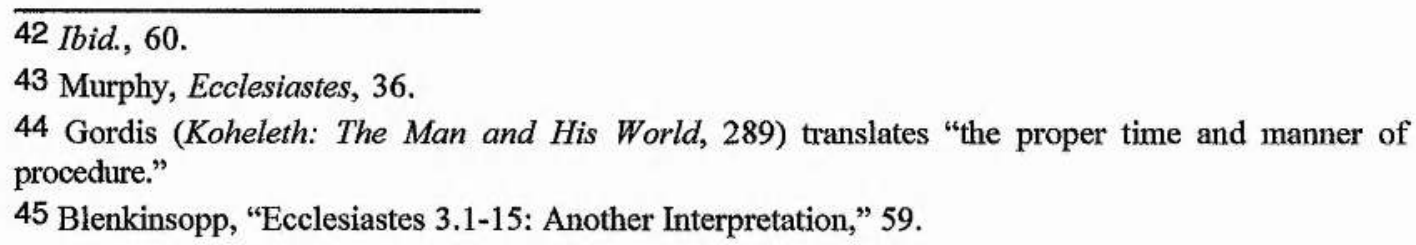
procedure."

45 Blenkinsopp, "Ecclesiastes 3.1-15: Another Interpretation," 59. 
oath the God has sworn concerning kingship). 46 This passage, and the relationship between king and God, will be considered in more detail in Chapter 5 of this thesis. However, if one understands the king as God's subordinate, as 8:2 would appear to suggest, then one can explain the statement: "the heart of the wise man knows time and judgement" as a recognition of the fact that the king is placed there by God and that to obey the king's will is ultimately to obey that of God. Thus, the wise mind recognises "time" and God's will behind it when it occurs, rather than being able to recognise the "time" to act appropriately. 47 This reading has the added advantage that it harmonizes with the context of $3: 1-15$, if one also understands this deterministically.

In the same context, it is significant that Qohelet again echoes the thought of 3:1 in his statement in 8:6: :Because to every matter there is time and judgement, the misery of humankind is great"). A variation of the same formula, as we have seen, is found in 3:17: "God shall judge the righteous and the wicked because there is a time for every matter (עת לכל חיץ) and concerning every work there." 48 In that passage, it referred to God's action at the "appointed time." Here too, it must mean the same, for in 8:7 additional reasons are given for humankind's sorry situation: "for he does not know what will happen, for who can tell him when it will happen?"

If "time" refers to an ideal moment for action (which human beings are unable to acheive), then $8: 6$ would mean "human beings are wretched because they are unable to act at the correct time." There is, however, no causal connection between

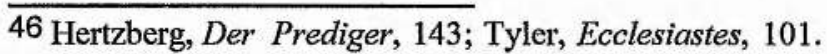

47 Hertzberg (Ibid., 144), Ginsberg (Qohelet, 106) and Fox (Qohelet and His Contradictions, 247)

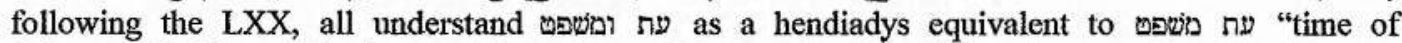
judgement" although "judgement" is understood by Fox in the traditional sense of God judging the human evil which the despotic ruler of $8: 2-5$ is said to represent.

48 Lauha, Kohelet, 149-50; Fox, Ibid.
} 
this reading and the fact that human beings are ignorant of the future. Though human beings may fail to act at the correct time, they retain some control over their own destiny. Only by understanding "time" as referring to divinely imposed action (i.e. determinism) can one retain the causal link between 8:6 and 8:7 (i.e. human beings are wretched because all their actions are controlled by the deity [8:6]; as a result they have no control over their own future, nor do they even know what will happen to them). 49

Thus, from both 3:17 and 8:5-6, two things may be inferred: (i) that Qohelet agrees with his statement in 3:1 outlining the theme of 3:2-8 (contrary to what one would expect if he were arguing against it) and (ii), that עת, or can be, linked with God's judgement. Thus, evidence not only from the immediate context of $3: 1-15$, but also from the wider context in Ecclesiastes refutes Blenkinsopp's thesis that Qohelet is engaged in a dialogue in this text.

\section{(b) Concluding Remarks: The Question of Free Will}

The problem with understanding Ecclesiastes as a deterministic text is that Qohelet presupposes a certain amount of free will in life.50 As I suggested earlier in this chapter, it is most likely this fact that underlies non-deterministic readings of 3:2-8. However, even commentators such as Blenkinsopp and Whybray understand Qohelet as advocating in Ecclesiastes a mixure of necessity and free will; it is simply that this necessity is understood to be limited. Occurrences in life are "predisposed" rather than "preordained." What if it is free will rather than necessity which is restricted? Does Qohelet have any kind of system which explains how human free will can exist and what are the things over which humanity has control? If it can be

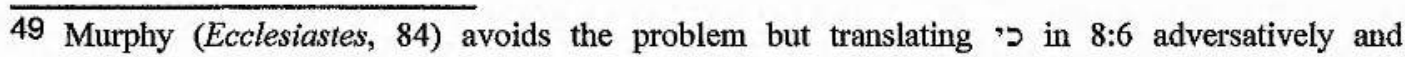
understanding 8:6b-7 as an attack on the "traditional" wisdom of 8:5-6a.

50 Podechard, L'Ecclésiaste, 192. 
shown that Qohelet does indeed have a rational system of free will which fits in with the deterministic world view in Ecclesiastes, this will do much to relieve the tensions which exist in our current understanding of Qohelet's work.

This problem will in fact be considered in Chapter 5 of this thesis. For now, however, the evidence so far adduced in this thesis would appear to support the idea that Qohelet views events in life as largely determined by God, and that though there may be some instances in which human beings have a degree of control over their destinies, these are seemingly limited. There is after all, "a time for everything; an appointed time for every purpose under heaven." 


\title{
Chapter 4 The Work of God
}

\author{
I. Introduction
}

\section{a. Modern Commentators}

In Eccl 8:17a, most commentators understand the particle 2 as initiating an object clause (GKC $§ 157 \mathrm{~b}, 117 \mathrm{~h}$ ), and English-speaking scholars accordingly translate the Hebrew:

\section{ראיתי את כל מעשה האלהים כי לא יוכל האדים למצוא את המעשה \\ אשר נעטה תחת השמשט}

"Then I saw all the work of God: that no-one can find out the work which is done under the sun."1

The same approach can be seen in the work of French commentators such as Podechard and Glasser, who translate ' 2 with que, although Podechard's translation, alors, j'ai reconnu (au sujet de) toute l'oeuvre de Dieu, que l'homme ne peut découvrir l'oeuvre qui se fait sous le soleil, implies a recognition that the human inability to discover wisdom is just one aspect of "the work of God."2 Barucq also sees a problem with this usage, and omits an equivalent for 2 from his translation of the passage: alors j'ai considéré l'oeuvre de Dieu. L'homme ne peut saisir l'oeuvre qui s'accomplit sous le soleil, rightly going on to remark about Qohelet's consideration of "the work of God" in this passage, il ne dit pas ce qu'est cette action, en quoi elle consiste. ${ }^{3}$

German commentators take their cue from Luther who translates, Und ich

\footnotetext{
1 Fox (Qohelet and His Contradictions, 253-5), following F. Ellermeier (Qohelet [Herzberg: Erwin Jungfer, 1967] 295-300), appears to be alone among English-speaking authors, translating "that is." 2 Podechard, L'Ecclésiaste, 406; Glasser, Le procès du bonheur par Qohelet, $136 \mathrm{n}$. c.

3 Barucq, Ecclésiaste, 153, 156.
} 
sah alle Werke Gottes, daß ein Mensch das Werk nicht finden kann, das unter der Sonne geschieht. The translation of $כ$ by $d a \beta$ is evident, for example, in the work of Strobel, 4 although Ellermeier's special epexegetical rendering of the subordinate clause in $8: 17 \mathrm{a}$ is demonstrated in his translation of כי by nälich.5 Lohfink's translation, ...da sah ich ein, daß der Mensch...das Tun Gottes in seiner Ganzheit מי with daß but removes das Tun Gottes (מעשה האלהים) from the main clause to the subordinate clause, equating it with das Tun, das unter der Sonne getan wurde (המעשה אשר געשה השמשט).

With few exceptions therefore, the translations of modern commentators suggest that Qohelet's meaning in Eccl 8:17a is that "all the work of God" is entirely taken up with preventing human beings from discovering wisdom. If such were Qohelet's thought, then he expresses it rather clumsily: nevertheless, those few commentators such as Barucq and Lohfink, who see contextual problems with this idea are forced into a position in which they must rearrange the passage, or leave the crucial word $\supset$ untranslated.

\section{(b) The Versions}

Although the translation of $כ$ as "that" in this passage is supported by the LXX's ött, the Peshitta's x understood the particle כי causally (GKC $\S 148 b)$. This is true also of the Targum, which adds extra material to the Hebrew of $8: 17$ in order to clarify the meaning of the verse:

וחזית אנא ית כל אובד גבורתא דיי ארום דחילא הוא ולית ליה רשו לאנש

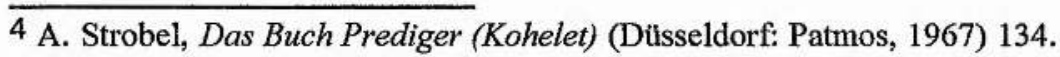

5 Ellermeier, Qohelet, 299.

6 Lohfink, Kohelet, 63.
} 
לאשכחא ית עובד גבורתא דיי דאתעביד בעלמא הדין ותחות שמשא

"I saw every mighty work of the Lord for it is awesome, and a human

being is not permitted to find out the mighty work of the Lord which is done in this world under the sun."

Part of the reason for the causal rendering of כי כרום by is contextual, for the translation of the Targumist demonstrates that he equates "the work of God" with "the work which is done under the sun."

The Vulgate's, et intellexi quod omnium operum Dei nullam possit homo invenire rationem eorum quae fiunt sub sole ("And this I understood of all the works of God: that a human being can find no reckoning of those things which are done under the sun") is suggestive of a similar contextual problem which this translator had in equating "all the work of God" with the prevention of human beings from attaining knowledge. Rather, the prohibition is portrayed as a single aspect of God's work. Although כי כs not concretely represented, being rather implicit in the relative pronoun quod (i.e. "this I understood...[that]"), it seems clear that the translator of the Vulgate attempted to balance contextual considerations with his desire to follow the LXX in understanding $כ$ as the beginning of an object clause.

Of the versions, only the LXX both retains something approaching the original structure of the Hebrew and interprets 2 as the beginning of an object clause: most likely, this has more to do with the Aquilan character of the LXX translation of Ecclesiastes than with hermeneutical accuracy. The translators of the Vulgate, Peshitta and Targum appear to be, to a greater or lesser extent, baffled by the structure and sense of the Hebrew of this passage. At the very least, a contextual problem is implied by the approaches of the Vulgate and Targum, and the causal renderings of $\supset$ by the Peshitta and Targum (the Semitic versions) may be suggestive 
of a grammatical problem with the modern understanding of 2 as introducing an object clause.

\section{Contextual Evidence}

In Eccl 1:14, Qohelet makes the surprising claim, "I have seen (ראה) all the works which are done under the sun, and behold, all is absurdity and shepherding the wind." At first sight, this appears to contradict his statement in 8:17 that "Nobody can find out (מצא) the work which is done under the sun."7 That Qohelet's original statement is not simply a vain boast which he revises in the light of his investigations is suggested by his comment in 8:9, in which he states, "All have I seen (ראה), and applied my mind to every work which is done under the sun."

Qohelet thus appears to make a fundamental distinction between "seeing" and "finding" the events which go to make up existence: Qohelet first observes events, and then applies his mind to interpret, or "find out" their meaning, thereby hoping to gain an insight into the workings of the world. This distinction is underlined if $1: 13$, "I applied my mind to seek and to search out by wisdom, concerning all which is done under heaven" is compared with the statement,"I have seen all the work which is done under the sun," in $1: 14$, which underlines his qualifications for the investigation which he proposes.

The language of seeking and finding is largely restricted to a few passages in which Qohelet alludes to the intent of his search (cf. esp. $1: 13 ; 3: 11 ; 7: 23-29 ; 8: 17$ ). The verb דרש occurs only in $1: 13$, but תור occurs in $1: 13 ; 7: 25$. More common terms are בקש $(3: 11 ; 7: 14,24,26,27$ [twice], 28 [thrice], $29 ; 8: 17$ [thrice]; $9: 10,15 ; 11: 1 ; 12: 10)$. From the contexts in which these terms appear, it seems that very often they have to do with the acquisition of

\footnotetext{
7 Whybray (Ecclesiastes, 49) suggests that "all the works which are done under the sun" in 1:14 may simply refer to the actions which Qohelet performs in the course of his investigation. This is a minority view, however.
} 
knowledge, particularly when the object of the verb is the term חשבון ("the sum of things"-7:25, 27, 29) or formulaic phrases involving the term ("work"), such

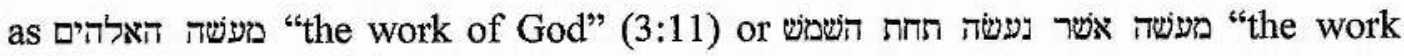
which is done under the sun" $(8: 17)$. This link between these verbs and the acquisition of knowledge is reflected in Whybray's understanding of the verb מצא as having the meaning "find out", Crenshaw's translation "fathom", or that of Gordis, "discover."'

This connection is also evident in the parallel usage of the verbs תור/בשי and in 7:25 and ידע 8:17. Qohelet plays on this theme in 9:10: "Whatever your hand finds to do, do mightily; for there is no work, nor device, nor knowledge (דעות), nor wisdom in Sheol where you are going." Likewise, Qohelet's statement in 3:11, "also (God) has put eternity in their minds so that no-one finds out the work which God does from beginning to end" is followed by a positive statement of what knowledge is available to Qohelet despite his failure to "find out" the work of God: "I know (ידע) that there is nothing better than to rejoice and to fare well during life" (3:12).

Thus, Qohelet is able to "see" all the events which go to make up existence $(1: 14 ; 8: 9)$, but though he may apply his mind to their interpretation $(1: 13 ; 8: 9)$, he confesses "nobody can find out the work which is done under the sun...even if a wise man claims to know it, he is not able to find it" (8:17).

Gordis, Fox and Murphy point out that for Qohelet, "the work of God" (משר השלה האלהים/מעשה האלהים) work(s) which is/are done under the sun" (מששה רע אשר נעמה/דמעמה שנעשה/מעשים) השמש השיש

8 Whybray, Ibid., 74; Crenshaw, Ecclesiastes, 91, 153; Gordis, Koheleth: The Man and His World, 156, 186.

9 Gordis, Ibid., 298-9; Fox, Qohelet and his Contradictions, 175; Murphy, Ecclesiastes, 13. 
conclusion of the Targumist. Qohelet views "all the work of God" (8:17) and can order the reader to do likewise $(7: 13)$, but this work cannot be "found out" (מצ-3:11) or "known" (מידע-11:5). Likewise, Qohelet and others can "see the work which is done under the sun" $(1: 14 ; 2: 17 ; 4: 3)$, but it cannot be "found out", i.e. interpreted to give a meaningful pattern to existence $(8: 17)$.

If this is the case, the translations of $8: 17 \mathrm{a}$ offered by these commentators, וראיתי את כל מעשה האלהים כי לא יוכל הארם למצוא את המעשה אשר בעשה תחת השמשט

"then I saw all the work of God, that no-one can find out the work which is done under the sun", must be erroneous. Although God eveidently restrains human beings from discovering the "works which are done under the sun" in $8: 17$, the act of prevention itself is not "all the work of God": rather, this phrase refers to the multitude of individual actions which go to make up existence.

\section{Grammatical Evidence}

There are, in addition, sound grammatical reasons for rejecting the notion that כ in $8: 17 \mathrm{a}$ is used epexegetically, or that it introduces an objective clause. While it is true that an objective clause governed by a transitive verb such as may be introduced by the particle כי (GKC $\S 157 b)$, in such cases the subordinate clause is the sole object of the verb, e.g. Gen 6:5, and the Lord saw that the wickedness of humankind was great." Sometimes a second object is expressed by such a clause (GKC $\S 117 \mathrm{~h})$ : the essential feature of these constructions is that the object of the main clause becomes the subject of the subordinate clause.

In order to illustrate this pattern, the examples of this phenomenon cited in GKC $\S 117 \mathrm{~h}$ are given below, with the object of the main clause underlined and the וירא אלהים את האור כי מוב 1:4 subject of the subordinate clause italicised. Thus, Gen 
"and God saw the light, that it was good" or Exod 32:22, אתה ידעת העם כי ברע היא "You know the people, that they are set on evil." Examples of the same phenomenon with the verb ידע are cited for 2 Sam 3:25; 17:8; $1 \mathrm{Kgs} 5: 17$. Examples involving the verb ראה are cited for Gen 6:2; 12:14; 13:10; 49:15; Exod 2:2; Ps 25:19; Prov 23:31; Job 22:12; $\operatorname{Eccl} 2: 24 ; 8: 17.10$

This pattern is followed without fail in all of the examples cited, except in Eccl 8:17:

וראיתי את כל מעשה האלהים כי לא יוכל האדם למצוא את המעשה אשר נעשה תחת השמש

"Then I saw all the work of God, that humankind cannot find out the work which is done under the sun."

If 'כere to mean "that", initiating an objective clause, we should expect the subject of the clause to be המעשה אשר נעשה תחת השמש, מעשה האלהים, or more likely את כל מעשה האלהים in the main clause. Instead, the subject is הוא האדם

Another possibility has been proposed by Fox, building on the detailed treatment of the syntax of this verse by Ellermeier. 11 In this argument, ' $\supset$ is a special usage, introducing an epexegesis by Qohelet of the expression מעטה האלהים. As support for this hypothesis, Fox cites as a direct parallel a use of the term in Jon 3:10, God saw their works, that they repented of their evil way." To suggest that this is simple epexegesis, however, may be a false argument, since we have seen that constructions involving $כ$ appear to be subject to rigid rules. Again, in order to illustrate how 2 is used in this passage, (part of) the object of the main clause is underlined and the subject of the main clause 
italicised "God saw the works-of-them, that they had repented of their evil way." On the analogy of this example, we should expect Eccl 8:17a to say something along the lines of "Then I saw all the work of God, that he..."

Although the usage of ' $\supset$ in Jon 3:10 is unique, it is not entirely dissimilar to occurrences introducing an objective clause: e.g.:

ויראו בני האלדים את בנות האדם כי טבת הנה

"And the sons of God saw the daughters-of-men, that they were fair" (Gen 6:2).

Here it is the nomen regens of a genitive construction which becomes the subject of the subordinate clause. In Jon 3:10, it is what would be the nomen rectum in an equivalent construction.

The probable reason for this strange use of $כ$ in Jon 3:10 is that it seems to serve as a substitute for the relative pronoun since the thought of this verse would more normally be expressed in Hebrew:

וירא האלהים את מעשי עם נינוה אשר הם שבו מדרכם הרעה

"And God saw the works of the people of Nineveh, who had repented of their evil way."

Since the putative מעש עשיהם עם נינוד, the relative pronoun אשיר cannot be used since it would then refer to the actions which had been performed, rather than to their doers. The use of $כ$ here resolves that problem with a simple circumlocution. אשר frequently have the same sense in object clauses (GKC §157a).

If we compare Eccl 8:17a, וראיתי את כל מעשה האלהים כי לא יוכל האדם למצוא, 
it is clear that האדם as the subject of what is thought to be the subordinate clause bears no relation to the object of the main clause, contrary to every other usage of in this sense in the Hebrew Bible. One is forced to conclude therefore that $כ$ should be translated in a different way.

The grammatical and contextual difficulties involved in understanding 2 as initiating an object clause in 8:17a underly the loose translation of this verse by the Vulgate and the causative renderings ("because") of כ by the Peshitta and Targum. It is, however, difficult to see how a causative rendering can help to clarify the meaning of the verse as we have it in Hebrew. Nor can כ 2 in Eccl 8:17a be rendered adversatively by translating as "but", since כ can be used in this sense only after a negative clause (GKC $\S 163$ ). The best solution is therefore to understand the particle affirmatively (GKC §159ee). Such an interpretation is in keeping with Qohelet's own usage, since most commentators understand כי כי ased in this manner by Qohelet in one or all of $4: 16 ; 7: 7,20.12$ Thus, Eccl $8: 16-17$ should be translated:

\begin{abstract}
When I applied my mind to know wisdom, and to see the business which is done upon the earth (my eyes seeing sleep neither by day nor by night), then I saw all the work of God. Surely no-one can find out the work which is done under the sun: for though a man labour to seek it out, yet he shall not find it. Moreover, though a sage claim to know it, yet he shall not be able to find it.
\end{abstract}

The affirmative ' $\supset$ in 8:17a serves to underline Qohelet's findings about the unattainability of wisdom previously made in 7:23-25. Thus it is entirely consonant with the emphatic tone of $8: 17$ as a whole. Introducing the results of Qohelet's observation, it paves the way for his very definite conclusions about humanity's inability to discover true knowledge, further emphasised by the appearance of such

12 Crenshaw, Ecclesiastes, 112, 132, 140; Fox, Ibid., 209; Gordis, Koheleth: The Man and His World, 162; Murphy, Ecclesiastes, 41. 


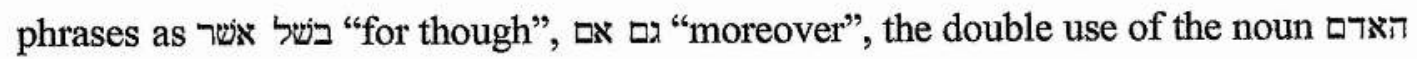
and the phrase לא יוכל, and the threefold repetition of the verb מצא which occurs in this verse.

\section{Implications for Determinism}

This chapter has now considered the question of whether "the work of God" can be said to be coextensive with "the work which is done under the sun" in Ecclesiastes as Gordis, Fox and Murphy have suggested. 13 The contextual evidence adduced in this chapter certainly bears out such an assertion. A problem with this view has been the traditional translation of $8: 17 \mathrm{a}$, "Then I saw all the work of God, that no-one can find out the work which is done under the sun" which appears to differentiate between the two concepts. This tension has now been to some extent resolved by demonstrating the difficulties (not least grammatical) associated with understanding 8:17 in this way: these difficulties are also reflected in the evidence of the versions which provide no real consensus as to an appropriate translation for the verse.

The case for understanding "the work of God" and "the work which is done under the sun" as essentially one has been strengthened, but some questions remain unanswered: what implications does this identification have for understanding Qohelet's overall theory of determinism? Why does Qohelet use two different phrases to express the same idea?

The difference between the two concepts is simply one of emphasis: "the work which is done under the sun" refers to human action and thought (cf. $4: 1,3$ ). The parallel phrase "the work of God" refers to divine activity. Yet, because Qohelet is a determinist, human action and thought is controlled by the deity. Any real

13 See $n .9$ above. 
distinction between human and divine actions therefore disappears. This, then, explains why Qohelet uses the same language when speaking of both, makes both the goal of his search, and thereby identifies both as one and the same thing.

Qohelet's conclusion regarding the search for "the work of God/the work which is done under the sun" is that a successful outcome is impossible. By contrast, Qohelet advises humanity that they should "find pleasure in their own works" (3:22). Though God may act to prevent human beings from finding out "the work of God", Qohelet bases his advice to find pleasure on the fact that "God has already approved your works" (כבר רצה האלהים את מעשיך-9:7). This same emphasis on concerning oneself with one's own actions (as opposed to those of God or the rest of humanity) is also implicit in the tone of the Royal Experiment:
I made great my works (הגדלזי משמי)...I made myself gardens and orchards (ל י עטיתי)...I made myself pools of water (עשיחי לי)...I got myself male and female בעל (עיתי לי (עית)...then I looked on all the works which my hands had doners (מעשי שטשו ידי and on the labour which I had laboured to do (ובעמל שעמלתי לעשות), and behold all was vanity... (2:4-11)

The impossibility of human attempts to break free of divine control is only underlined by Qohelet's remark that "I know that whatever God does will be eternal: nothing can be added to it nor anything taken from it..." (עליו אין להוסיף וממנו אין טרוגל-3:14). The divine plan cannot be altered by human actions.14 More importantly, because "the work of God" is expressed in human actions, this verse suggests that human beings are unable to "add to" the work of God by acting on their own initiative, nor can they "take away from" God's work by failing to perform the actions which he has determined for them.

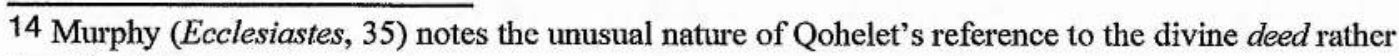
than the divine word. 
The equivalence of "the work of God" with "the work which is done under the sun" is of great importance in understanding the nature of Qohelet's deterministic worldview. In this context, Qohelet's use of עמשה referring to the actions of individuals is also significant, for Qohelet's conclusion is that since one cannot understand "the work of God" or break free from its power, one should allow oneself to find pleasure in "one's own works" (3:22). This indeed is the essence of Qohelet's message. 


\section{Chapter 5 \\ Qohelet and the Problem of Free Will}

\section{Introduction}

In a recent study of the language of the book of Ecclesiastes, Seow has linked Qohelet's usage of $\sqrt{ }$ with those of Aramaic legal documents dating from the Persian period. 1 It is clear from biblical and extrabiblical texts of this time that the root can have a "technical" legal/economic nuance, usually referring to the legal rights which an individual may be granted to impose taxes, dispose of goods or slaves, or to perform certain actions specified in the document concerned. 2 Moreover, Qohelet does indeed appear to use Vטש in this sense, particularly in $2: 19 ; 5: 18$ (Eng. 19); 6:2, and perhaps $7: 19.3$

Several commentators have in the past argued that Ecclesiastes is a composition dating from the fourth century, pointing out its lack of Grecisms or of concrete evidence to connect the thought of Qohelet with that of the main Greek philosophies of the third century B.C.E.. ${ }^{4}$ However, Seow's suggestion that

\footnotetext{
1 Seow, "Linguistic Evidence and the Dating of Qohelet," 653-4. Seow follows D. S. Margoliouth ("Ecclesiastes" in Jewish Encyclopaedia [New York/London: Funk \& Wagnalls, 1901-7] 5.32-33) in ascribing a fourth century date to Ecclesiastes on this basis, making use of an extensive study of the technical sense of $\sqrt{w}$ w by D. M. Gropp ("The Origin and Development of the Aramaic Sallit clause," JNES 52 [1993] 34).

2 Three apparent technical usages of $\sqrt{ }$ של $7: 24$; Neh 5:15). An extensive list of the extrabiblical literature is to be found in Gropp ("S 5 allit.t Clause," $34 \mathrm{nn} .28,29$ ) with additional citations by Seow ("Linguistic Evidence," $653 \mathrm{nn} .57,59$ ).

3 Whereas Seow (Ibid., 653) takes שלישים in Eccl 7:19 in the economic sense of "proprietor" (i.e. landowner), Crenshaw (Ecclesiastes, 142) understands it in a political sense and translates "administrative officials." Crenshaw to some extent in his political rendering follows Lohfink ("Melek, Sallițtund mósë bei Kohelet und die Aufassungzeit des Buchs," Bib 62 [1981] 541-43), who understands the term to refer to local governors (although whether one would expect to find ten in one place is doubtful). I incline towards Seow's translation here for the sake of consistency with the clear economic sense with which Qohelet invests the term in 2:19; 5:18 (Eng. 19); 6:2. Crenshaw's reading remains plausible however, particularly in view of the possibly political usage of Vט

4 Delitzsch, Ecclesiastes, 214; Kugel, "Qohelet and Money," 45-49. Scott (Proverbs Ecclesiastes, 198) has argued for a dating towards the end of the Persian period, although he does not rule out the possibility of a dating in the early third century.
} 
Qohelet's use of 1 is characteristic only of Persian times presents a significant challenge to the current consensus that the book of Ecclesiastes is a product of the Hellenistic period. 5 For this reason alone, it deserves closer scrutiny.

Before continuing further, it is as well to consider some of Gropp's conclusions concerning the use of $\sqrt{ }$ in Aramaic. His argument is that the Akkadian root s/t. "rule", "have power" also had a limited legal sense in the seventh century. This sense is then passed into Aramaic (where it is attested from the fifth century on). Its legal applications in this language are extended as the Persian period progresses. 6

The most significant part of Gropp's paper as far as Seow is concerned, however, is his statement that "After the Persian period, the meaning of sallit is increasingly restricted (my italics) to the political sphere, with the meaning "to rule, have dominion"; "ruler, commander."7 Yet the latter commentator appears to argue that the technical sense of $\sqrt{ }$ does not occur at all in the Hellenistic period, and uses this argument to date Ecclesiastes fairly conclusively to the fourth century.

\section{The $V^{a}$ be in the Persian Period}

The book of Ecclesiastes is a notoriously difficult text to date with any certainty, and Seow presents a persuasive case for a Persian setting. His arguments derive from socioeconomic as well as linguistic sources. ${ }^{8}$ Yet almost all could equally well apply to the Hellenistic period. The notable exception to this is his assertion that Qohelet uses $\sqrt{ }$ in the same technical sense which is found in the Persian

\footnotetext{
5 Most commentators currently argue for a mid-to-late third century date (e.g. Whybray, Ecclesiastes, 4-12). Others, among them Lohfink (Kohelet, 7) and Whitley (Koheleth: His Language and Thought, 132-46), have suggested an early- or mid-second-century background.

6 Gropp, "Sallit tClause," 35-36.

7 Ibid., 34.

8 Seow, "The Socioeconomic Context of 'The Preacher's' Hermeneutic," 159-195.
} 
period and that this root is replaced in legal contexts during and after the third century B.C.E. by $\sqrt{ }$.

As well as some usages in the books of Ezra and Nehemiah (Ezra 4:20; 7:24;

Neh 5:15), the legal sense of $\sqrt{ } V$ is attested as early as the fifth century B.C.E. in the Aramaic Papyri from Elephantine. ${ }^{9}$ It is also found in the Samaria Papyri from the fourth century B.C.E.. 10 Significantly, the latter documents are dated to the very end of the Persian period; it would seem reasonable to assume therefore that might retain a legal sense at least into the early Hellenistic era. Unfortunately, the lingua franca of this period for most legal documents was Greek and not Aramaic. 11 It is correspondingly difficult to prove that the use of the technical sense of $V^{\text {in }}$ legal contracts was discontinued in favour of $V_{\text {רש }}$ before the mid-to-late third century date assigned to Ecclesiastes by most commentators.

\section{The Vow in the Hellenistic Period}

\section{(a) The Book of Daniel}

In order to support his dating of Ecclesiastes to the Persian period, Seow cites the lack of any technical usage of $\sqrt{ }$ in in the book of Daniel, a work generally

\footnotetext{
9 See Gropp (" SallT,tClause," 31 n.2) for a full bibliography. Some of the more recent material cited includes E. Y. Kutscher, "New Aramaic Texts," JAOS 74 (1954) 239; R. Yaron, "Aramaic Marriage Contracts from Elephantine," JSS 3 (1958) 9-10; "Aramaic Deeds of Conveyance," Bib 41 (1960) 248-74; Y. Muffs, Studies in the Aramaic Legal Papyri from Elephantine, Studia et Documenta ad Jura Orientis Antiqui Pertinenta, vol. 8 (Leiden: Brill, 1969) 6, nn. 23 and 24; 39, n. $3 ; 41$, n. 2 134; 151, n. 3; 152-53; 176-78; 204; 206; 208.

10 F. M. Cross, "Samaria Papyrus 1: An Aramaic Slave Conveyance of 335 B.C.E. Found in the Wadi ed-Daliyeh," Nahman Avigad Volume, ErIsr 18 (Jerusalem, 1985) 7-17; "A Report on the Samaria Papyri," in J. A. Emerton (ed.), Congress Volume, Jerusalem, 1986 (VTSup 40; Leiden: Brill, 1988) 17-26; Gropp also considers the use of ("SallittClause," 32).

11 J. J. Rabinowitz (Jewish Law: Its Influence on the Development of Legal Institutions [New York: Bloch, 1956] 124-40), studying the Greek legal papyri from the Hellenistic period, appears to show that the successor to the classic Aramaic sa/lit tclause was an equivalent Greek kyrieia clause.
} 
ascribed to the third and late second centuries. 12 However, a close examination of the relevant texts in Daniel reveals several clear examples of the technical usage of שלט. In 2:38, Daniel tells Nebuchadnezzar, "Wheresoever humankind dwells, the beasts of the field and the birds of the heavens has He (i.e. God) placed in your power and has given you right of disposal (יהב בידך והשלטך) over them all." One does not exercise political power over animals, but one may be granted proprietorship. This particular image demands that ve understood in its legal/economic sense. A parallel is made between the everyday world of business transactions and kingship. It is as if God has signed a deed giving Nebuchadnezzar an estate complete with its livestock, or the hunting and trapping rights over the whole earth.

In the same context, Rabinowitz has drawn attention to the striking parallels between the legal terminology of papyrus Brooklyn 12 and the text of Daniel 4:14 (Eng. 17), 22 (Eng. 25), 29 (Eng. 32) stating that the formula used in the latter "was adopted from the phraseology of the legal document which was current in his day."13 In these particular examples, the phrase in question reads: די שליט עליא במלכות אנושאא ולמן די יצבא יתננה "That the Most High rules in the kingdom of humankind, and gives it to whomsoever he will") The context therefore makes it clear that the term in these locations refers not merely to "power" but to a legal "right of disposal." A modified version of this legal formula also occurs in Dan 5:21.

\section{(b) The Book of Ben Sira}

Two further usages of $\sqrt{ }$ (של occur in the book of Ben Sira $(4: 7 ; 9: 13)$. Due to

\footnotetext{
$\overline{12 \text { Seow, "Linguistic Evidence," }}$ 654. Elsewhere, I have argued that Qohelet was probably familiar with the court stories in Daniel ("A Contextual Reading of Ecclesiastes 4:13-16," JBL 116 [1997] 5773, esp. 61-63, 65-69, 72).

13 Rabinowitz, Jewish Law, 128-29 (cf. also pp. 131-33 for a similar usage of legal terminology in Dan 4:31[Eng. 34]-32 [Eng. 35]). The full text of the document may be found in Kraeling, The Brooklyn Museum Aramaic Papyri, 268-69.
} 
constrictions of space, I have attempted to avoid citations of vere where is some ambiguity as to whether it is being used in a technical or nontechnical sense. There is, however, no ambiguity when $\sqrt{ }$ ש one's legal right to perform certain actions. In Gropp's definition of such a clause, "....it is probably best to understand the term [i.e. שלטא] in the positive formulation as stating some legal right(s) in general terms which must be further specified by context. This specification is most unambiguously achieved by means of one or more complementary infinitives." 14

This specific construction of $\sqrt{ }$ ל 6 infinitive occurs in Eccl 5:18 (Eng. $5: 19) ; 6: 2 ; 8: 9$, but it also occurs in Sir 9:13, where Seow claims a nontechnical use of שלט Vet the expression, "Keep far from a man with the power to kill (שלטון להרג), and you will not be worried by the fear of death..." must surely be a technical usage of the root. Ben Sira warns not against being the companion of a man psychologically able to kill, nor even of a man with the money to hire assassins. Rather he warns against working for a powerful man with the legal right to put people to death if they displease him (cf. Prov 23:1-2 for a similar thought).

Although Vהשר "permit" occurs in Sir 3:22, the use of this root is by no means characteristic only of the Hellenistic period. The term רשיון "permission" is attested in Ezra 3:7 (in which book Vשer, as we have seen, also retains its technical sense). Thus there is no reason to think that $\sqrt{ } \sqrt{ }$ is being used in Ben Sira in preference to the technical sense of $\sqrt{ }$. Humanity's access to different types of wisdom is the topic of discussion in this particular text, so that been permitted") in Sir 3:22 cannot reasonably be construed in the sense of "right of disposal." The term נסתרות ("that which is hidden") to which it is in opposition, conveys impossibility, rather than illegality. The evidence therefore suggests that 14 Gropp, "SallịtClause," 34, citing Muffs (Studies in the Aramaic Legal Papyri, 41 n. 2). 
Vשל retained its technical sense into the second century, and that $\sqrt{ }$ in Ben Sira has much the same general meaning as in the Persian period.

\section{(c) Later Texts}

While evidence from later writings shows that $\sqrt{\text { ה }}$ may sometimes be used in place of 1 in legal contexts, the validity of these sources in dating Ecclesiastes to the Persian period is limited. The Murabba at and Nahal Hever documents, for example, are from the time of Bar Kokhba (early second century C.E.). Likewise, the Nabatean tomb inscriptions utilising $\sqrt{ }$ are of late date, coming mainly from the 1st century C.E.. 15

Significantly, the economic/legal sense of $\sqrt{ }$ te seems never to have died out entirely: a Syriac bill of sale dated 243 C.E. containing an elaborate sal/it.t clause remains extant.16 This technical usage also appears in the Talmud Yerushalmi. For example, $y$. Naz IV 53b speaks of a woman having legal authority over her husband's property (במשלטח על נכסיו). Similarly, y. Kethub IX 33a concerns a woman authorized to manage her husband's property during his lifetime (נכסים שxשתלטה בהן). Both use $\sqrt{ }$ טל in its legal/economic sense, specifically in the context of property (נכסים). The same context occurs in Eccl 5:18 (Eng. 5:19); 6:2, in which people are

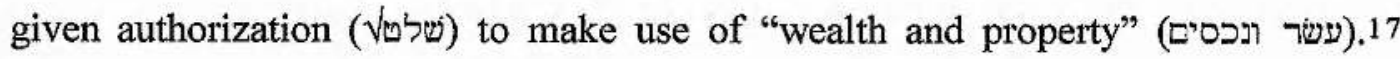
Medieval Jewish deeds of conveyance also makes use of the sallit.t clause, as Rabinowitz has demonstrated. 18

\section{Consequences for the Dating of Ecclesiastes}

\footnotetext{
15 The relevant literature is cited in full by Gropp (Ibid., $34 \mathrm{nn} .28,29$ ).

16 J. A. Goldstein, "The Syriac Bill of Sale from Dura-Europos," JNES 25 (1966) 11-12.

$17 \mathrm{Cf}$. the Yiddish proverb: "The miser has no right of disposal (שליטה) over his possessions" cited by Gordis, Koheleth: The Man and His World, 255.

18 Rabinowitz, Jewish Law, 132.
} 
To conclude then, Qohelet's use of the technical sense of $\sqrt{ }$ (be finds several parallels in documents from the fifth and fourth centuries B.C.E., but this meaning of the root evidently survived throughout the Hellenistic period and well into the Christian era. Indeed, it might even be argued that the figurative way in which $\sqrt{ }$ is used in Daniel, with the deity issuing property grants to favoured human subjects, has more in common with the thought of Qohelet than do the purely literal uses of this root in the legal papyri from the Persian period, or in Ezra-Nehemiah. For the time being, the debate as to the date of composition of the book of Ecclesiastes cannot be considered closed.

\section{The Book of Ecclesiastes: Text and Context}

Many commentators have argued that the catalogue of times in 3:1-8 represent Qohelet's expression of the divinely determined nature not merely of human actions, but even of human thought and feeling. 19 This alleged deterministic worldview has biblical antecedents, as Fox and Murphy have pointed out.20 For the most part, however, determinism in Jewish thought is associated with the apocalyptic literature of the Hellenistic era, or with the contemporary wisdom literature. 21

A parallel also exists between Qohelet and the Stoic school who reformulated the work of earlier Greek philosophy in order to combine the concept of determinism with that of free will. 22 A similar outlook on the nature of existence, however, is not

19 Delitzsch, Ecclesiastes, 255-9; Scott, Proverbs Ecclesiastes, 220-1; Fox, Qohelet and his Contradictions, 192. Recently, Blenkinsopp has taken a different tack in arguing that 3:2-8 is a text stressing opportuneness against which Qohelet takes issue with a deterministic commentary in 3:9-15 ("Ecclesiastes 3.1-15: Another Interpretation," 55-64).

20 Fox, Qohelet and his Contradictions, 195; Murphy, Ecclesiastes, 33.

21 Von Rad, Wisdom in Israel, 264.

22 Among those who have posited direct Stoic influence on Qohelet's work are Tyler (Ecclesiastes, 10-29), Plumptre (Ecclesiastes, 30-32), Bickerman (Four Strange Books of the Bible, 141-49), and Gammie ("Stoicism and Anti-Stoicism in Qoheleth," 169-187). 
conclusive proof of cross fertilisation and in fact, commentators have been hard pressed to find convincing evidence of specific Greek influence, preferring to ascribe similarities between Qohelet and various Greek philosophies to a general Hellenistic Zeitgeist. 23

Although Delitzsch dated Qohelet's work firmly in the Persian period, he nevertheless saw evidence of determinism in Ecclesiastes, being followed in this position by Scott.24 While commentators may differ as to the dating of Qohelet's work, most accept that it betrays a belief in some form of determinism, even if some are wary of ascribing such an idea to the well-known catalogue of times in chapter 3.25

The single greatest problem associated with understanding 3:1-8 as a deterministic text, is that Qohelet appears elsewhere to presuppose a certain amount of free will in human existence. 26 If all, including human thought, is predetermined, there would appear to be little point in producing a work of wisdom which offers advice on how to approach life. Moreover, Qohelet regularly uses the imperative form in his work (4:17 [Eng. 5:1]; 5:2 [Eng. 5:1], 4 [Eng. 3], 6 [Eng. 5]-8 [Eng. 7]; $7: 9,10,13,14,16-18,21 ; 8: 3 ; 9: 7-10 ; 10: 4,20 ; 11: 1,2,6,9,10 ; 12: 1,13)$, a rather futile exercise if we have no control over our actions.

The problem of free will and how Qohelet's evident acceptance of such an idea might be reconciled with those texts in Ecclesiastes which appear to have deterministic tendencies is fundamental to our understanding of Qohelet's worldview. Nevertheless, no work of which I am aware has attempted to consider the one in the light of the other. The tendency of commentators has been either to

\footnotetext{
23 Murphy, Ecclesiastes, xlv.

24 Delitzsch, Ecclesiastes, 214.

25 Blenkinsopp, "Ecclesiastes 3.1-15: Another Interpretation," 55-64; Whybray, Ecclesiastes, 67.

26 Podechard, L'Ecclésiaste, 192; Blenkinsopp, "Ecclesiastes 3.1-15: Another Interpretation," 62.
} 
ignore the problem completely, or to argue that contradictions in Qohelet's work are a deliberate reflection of the contradictory nature of life. 27

(a) Humanity and God $(5: 18 ; 6: 2 ; 2: 19)$

Seow is the latest of a long line of commentators who have pointed to the strongly Aramaizing tendency of the Hebrew in the book of Ecclesiastes.28 If Qohelet's use of של של can be linked to its legal/economic sense of "delegated authority", "right of disposal" or "proprietorship" in Aramaic texts, then one of the ways in which the idea of free will can be combined with a concept of determinism becomes evident. The context in which Qohelet uses $\sqrt{ }$ usually makes it clear that he is speaking of some kind of delegated authority: indeed, it is a sine qua non in the argument of many commentators.

In $5: 18 ; 6: 2$, God is depicted as a divine ruler who grants to certain of his human subjects "wealth and riches and authorisation to eat of them," refusing this same authorisation to others. Ultimately the picture drawn of God and his relationship with humanity is very similar to that of these Aramaic texts in which the שליט has authorisation from above to dispose of (other people's) goods. In this case, the goods, "wealth and riches" (עשר ונכסים-5:18; 6:2) are part of the gift of God.29 That is to say, they are not earned but apportioned by God and the individual has no right to retain the goods or to treat them as his without the deity's authorisation to do so. Indeed, the parallel becomes still closer when one considers passages such as $2: 26$, "God gives wisdom, knowledge and joy to the one who pleases him, while to

27 The latter view has been expressed by Delitzsch (Ecclesiastes, 183) and more recently by Fox (Qohelet and His Contradictions, 19-28).

28 Seow, "Linguistic Evidence and the Dating of Qohelet," 650. On this basis, others have argued that the Hebrew of Ecclesiastes represents a translation of an originally Aramaic text (F. C. Burkitt, "Is Ecclesiastes a Translation?" JTS 23 [1921-22] 22-27; F. Zimmerman, "The Aramaic Provenance of Qohelet," JQR 36 [1945-6] 17-45; C. C. Torrey, "The Question of the Original Language of Qohelet," JQR 39 [1948-9] 151-60; H. L. Ginsberg, Studies in Koheleth,] 16-39).

29 Whybray hints at the deterministic nature of such things ("Qoheleth, Preacher of Joy," 89). 
the sinner is given toil: to gather and to heap up and to give to one who pleases God." The riches and wealth "given" by God then may come indirectly through another's labour. 30

By way of contrast, the situation of the sinner in 2:26 is remarkably similar to that of the one in 6:2 "to whom God grants wealth, riches and substance...but not given him authority to eat of these things: instead, a stranger eats of them." The picture of God which begins to emerge is of a capricious king whose actions cannot be determined by his subjects. ${ }^{31}$ The terms ("good before God") and חוטא" ("sinner") which are devoid of moral content but which provide the reasons for some of his actions vis à vis his subjects only reinforce this view. ${ }^{32}$

The use of $\sqrt{ }$ in in $2: 19$ remains close to the parallel usage in Aramaic documentation. There the term is specifically used of the inheritance of Qohelet's wealth by another. A question mark remains over the source of the authorisation which denotes here. It may simply refer to the right of disposal given by (earthly) legal authorities to Qohelet's heir. Yet Qohelet himself seems unaware of who is to inherit (ומי יודע החכם יהיה או סכל): in this case the hand of the inscrutable deity would seem once more to be at work. ${ }^{33}$

In a world in which all, or nearly all, is predetermined, the meaning which של has here of authority (delegated by God) to act in some way makes it

\footnotetext{
30 Most commentators understand 2:26 in the sense that the "sinner" has these activities inflicted on him as a punishment. Gordis is alone in claiming that "the man who misses God's purpose, the enjoyment of life, is a sinner" (Koheleth: The Man and His World, 227). In other words, Gordis limits God's determinism by claiming that "to gather and to heap up" is the sin itself rather than the consequence.

31 Crenshaw comments on the "element of arbitrariness" in God's rule and the inability of human beings to perceive God's actions in the present or future. Both ideas, in his opinion, are suggestive of "some form of determinism" (Old Testament Wisdom: An Introduction, 136).

32 Hertzberg, Der Prediger, 82-3; Ginsberg, "The Structure and Contents of the Book of Koheleth," 139; Zimmerli, Der Prediger, 161-2. The idea that both terms are devoid of moral content is now generally accepted.

33 Fox, Qohelet and His Contradictions, 186. This is particularly the case if Qohelet is still speaking in his kingly persona.
} 
equivalent to a limited form of free will.34 It is significant that here the term Vשלט is used in the context of "eating" or utilising the material benefits which life has to offer, for this one area in which Qohelet uses imperative forms of the verb $(9: 7,8,9$; $11: 9,10) .35$ These, as I have pointed out, are indicative of the idea that human beings have a degree of control over their actions. One may indeed be granted של מור "authority" to enjoy life by God, but the individual may not exercise that authority: the aim of Qohelet's investigation is to exploit those areas in which human beings are granted the power to act independently, "to see what is that good which humanity should do under the heavens" (2:3). 36

\section{(b) Misuse of Free Will (8:9ff.)}

The use of של is not restricted to the idea of having "right of disposal" over material goods however. Just as in the Aramaic texts which form the background to Qohelet's thought (cf. esp. the Samaria Papyri), one may have "right of disposal" over other people.

Qohelet also speaks of "a time in which one person has authority over another to his hurt." The meaning of the ambiguous לרע לו has sometimes been understood to be that those who have power may injure themselves (So Symmachus,

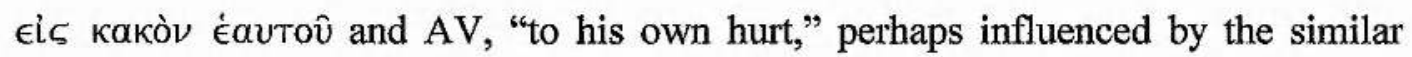
idiom לרעתו in 5:12 [Eng. 5:13]). However, 8:9 may also be construed in the sense

34 Cf. Murphy on $5: 18 ; 6: 2$ who emphasises the role of the deity. The situation in which not given to the rich person is seen as an active intervention by God ("[the] rich person...is prevented by God from enjoying his riches" [Ecclesiastes, 53]).

35 Whybray sees a sevenfold "joy" leitmotiv in which emphasis increases with each new affirmation of the worth of joy ("Qoheleth, Preacher of Joy," 87-8). Although the ability to enjoy life lies in God's gift (p. 89), the responsibility lies with human beings to make use of this ability.

36 In fact, the objective of Qohelet's search is described in several different ways, connected in particular with finding "the work which is done under the sun" or "the work of God." Both of these are equivalent (so Fox, Qohelet and His Contradictions, 175; Murphy, Ecclesiastes, 13), a necessary step before discovering the relevance of his findings for human beings (Rudman, "The Translation \& Interpretation of Ecclesiastes 8:17a," JNSL 23 [1997] 1-9). 
that one person has power over another to the detriment of the inferior party. This rendering is supported by the LXX, Peshitta, Vulgate and Targum as well as the vast majority of modern translations (cf. esp. RSV, "man lords it over man to his hurt"). 37

Two things should be noted about this verse. The word עת "(appointed) time" is generally used in Ecclesiastes to denote those events which are determined by God (cf esp. 9:11, 12 in which the net cast over humanity is a divine weapon), 38 so that God is ultimately the source of the authority which is enjoyed by the subject of this verse over his fellow. The second is that this is most likely a sallit.tclause as defined by Gropp with שלט followed by an infinitive stating what legal powers the subject enjoys. The elision of $\pi$ on a Hiphil Infinitive Construct after a preposition is not uncommon in the Hebrew Bible (GKC §53q). In this case, one person apparently has the legal right to harm another (לרע לו).

In this case, the subject which Qohelet is probing is one of theodicy. ${ }^{39}$ In a predetermined world, how can wickedness and evil be explained? To follow the implications of determinism to its logical conclusion would be to say that God is not merely directly responsible for human wickedness, but actually acts wickedly himself through his creatures. Unconventional as his thought sometimes is, Qohelet remains a Jew, and such an idea would be as unacceptable to him as to his contemporaries.

Qohelet's solution to this problem, and it is, he realises, a partial one, is that a person may be granted licence (שלט (של ) by God to dominate his fellows. This licence empowers the individual to act to the detriment of his fellow. It does not follow that

37 The same meaning is upheld by almost all commentators.

38 Rudman, "Woman as Divine Agent in Ecclesiastes," 417-18.

39 Fox, Qohelet and His Contradictions, 121. 
God wishes or intends wickedness: a choice is presented to humanity and evil chosen rather than good. This is the negative side to free will. The deterministic God is not therefore directly the author of wickedness but he does bear a certain degree of responsibility in that של שטון is granted to those who abuse it.

This is the idea explored in the succeeding verses, "and so I saw the wicked draw near and approach the place of the holy, walk about and boast in the city that they had done right (so Driver's emended text: ובשן ראיתי רשעים קרבים ובאים מקום 19:10)."40 The wicked may indeed boast that their actions are morally right, or at least "legal", because the deterministic God has shown his approval by allowing them to be carried out in the first place. 41 This problem of theodicy is explored further in the next verse: "because sentence against an evil act is not carried out speedily, the mind of humanity is fully made up to do evil."42 The fact that evil may be judged is a logical corollory of Qohelet's belief that evil stems from an abuse of שלטון rather than from actions directly determined by the deity. However, Qohelet is perplexed by the fact that God appears not to judge the wicked nor to strip them of their authority to act as they do. It is this divine inaction that the wicked are able to construe as approval of their actions, giving fresh encouragement to further evil.

\footnotetext{
40 The emendations of G. R. Driver ("Problems and Solutions," VT 4 [1954] 230-31) to the MT's so I saw the wicked buried, who had come and gone from the place of the holy, and they were forgotten in the city where they had done so," partially dependent on an earlier suggestion by Burkitt ("Is Ecclesiastes a Translation?" 25-6), are accepted by most commentators, though Gordis (Koheleth: The Man and His World, 295); Lohfink (Kohelet, 62), followed by Murphy (Ecclesiastes, 79) retain the MT's קברים "buried."

41 Cf. 9:7, "Go, eat you bread with pleasure...for God has already approved your works." In Fox's words on this verse, "If you are given the opportunity to enjoy life, that is in itself evidence that God has approved of the pleasurable activities you undertake" (Qohelet and his Contradictions, 259). The same view, however, equally applies to wickedness: the fact that God allows the opportunity for it to be committed, means that God has approved it. The wicked have "done right."

42 Fox in particular, emphasises God's apparent injustice in this verse, "Since the punishment which Qohelet has in mind is a divinely imposed death sentence, delaying punishment is tantamount to not carrying it out" (Ibid., 249).
} 
(c) Limitations of Free Will: Death $(8: 8)$

Qohelet's deterministic beliefs naturally mean that free will is limited: while much in life is determined by God, there are some things in life over which human beings are allowed no control under any circumstances. The example par excellence of this is death: "no-one has authorisation (שליט) over the breath of life to retain the breath of life, no-one has authority (שלטון) over the day of death." 43 Again, the final arbiter of life and death is God $(11: 5 ; 12: 7)$ and he alone determines the moment at which the life breath passes from the body and returns to its maker.

Death is associated with עת "appointed time" in the catalogue of divinely ordained times which limit and control human life (3:2), but Qohelet also speaks of the possibility of dying "before your time" (עתך-7:17). The implication of this verse is that God may alter a previously appointed time as a response to the "overly foolish" or "overly wicked" behaviour of the individual.44 Commentators have generally been puzzled by the advice not to be "overly wicked." Is Qohelet advising people to be somewhat wicked? The general consensus is that Qohelet is a realist who recognises that everyone does wrong at some point: he advises his reader not to abandon himself utterly to such practices.

The meaning of $\sqrt{ }$ (ש) which has been established in 8:9 and its implications for the interpretation of the succeeding verses again offers some explanation of this difficult passage. Wickedness is only possible as a result of the use/abuse of divinely granted שלטון and because it is "licensed", may go unpunished in the short term. The thrust of 7:17 would suggest that in the case of a major act of wickedness, God will intervene with the ultimate sanction: the punishment of death in this verse is aimed

43 Murphy suggests the divinely determined nature of death in this verse, alluding to $3: 2$ "a time to give birth, a time to die" (Ecclesiastes, 84).

44 Strange, The Question of Moderation in Eccl 7:15-18, 58ff. esp. 87. 
at those who are extreme in their behaviour. 45 Although God may be rebuked for being tardy in his punishment of the wicked, Qohelet clearly does believe in some form of judgement. 46

\section{(d) The King as Supreme Expression of Free Will (8:4ff.; 10:5)}

The king too in Qohelet is said to have של שטון. This is a significant remark because the king normally grants authority: he does not receive it. Should such a use of the term שלטון therefore be understood in a non-legal sense? This may be possible, but the fact that elsewhere Qohelet uses the term כח for "power" or "force" (4:1), would appear to suggest that the idea behind the term שלפון in this particular context would again be one of authority delegated to the king by God.

The phraseology of 8:2 "I counsel you to obey the king's command and that in respect of the oath of God" (אני פי מלך שמור ועל דברת שבועת אלהים) has again been something of a puzzle for commentators. 47 The use of signifying authority delegated by God, "free will" as it were, lends substance to the arguments of those commentators who have in the past suggested that the oath mentioned here is God's oath concerning kingship and not a human oath of loyalty to the king. The way in which Qohelet goes on to describe the king in 8:3 elucidates the idea of as free will: "he does what he chooses, for where the word of the king is, there is authority (כל אשר יחפץ יעשה באשר דבר מלך שלטון)." The statement that

\footnotetext{
45 Whybray and Fox see the expression "do not be very wicked" not as recommending moderate wickedness but as a concession to human weakness (Whybray, "Qoheleth the Immoralist? (Qoh 7:1617)" in J. G. Gammie et al. (eds.), Israelite Wisdom: Essays in Honor of Samuel Terrien (Missoula: Scholars, 1978) 197; Fox, Qohelet and His Contradictions, 235-36).

46 Fredericks defends the idea that Qohelet has a traditional conception of divine retribution ("Life's Storms and Structural Unity in Qoheleth 11.1-12.8," JSOT 52 [1991] 101).

47 Interpreters are divided as to whether the phrase שבועת אלהים "oath of God" is a subjective or objective genitive. Hertzberg understands the genitive as subjective, referring to God's oath concerning kingship (Der Prediger, 143), along with Tyler (Ecclesiastes, 101). Plumptre (Ecclesiastes, 175), Barton (Ecclesiastes, 149), Podechard (Ecclésiaste, 391) and most subsequent commentators understand the genitive as objective referring to a human oath of loyalty to the king with God invoked as a witness (Gordis, Koheleth: The Man and His World, 288; Scott, Proverbs Ecclesiastes, 240; Galling, Der Prediger, 110; Lauha, Kohelet, 148).
} 
the king "does what he chooses" is a remarkable one in the light of Qohelet's deterministic philosophy, for it suggests that the king enjoys a special relationship with God, acting as the deity's viceregent (cf. Ps 2:7; Dan 4:14 [Eng. 17], 22 [Eng. 25], 29 [Eng. 32]; 5:21).48

The suggestion that שלמטן may retain its legal sense of (delegated) authority is lent support by the work of A. Hurvitz who has shown that the Hebrew expression כל אשר חפץ עשוה is used in a distinct legal sense.49 Seow too has pointed out that this expression elsewhere in the Hebrew Bible is used only of God.50 It would appear then, that Qohelet is being consistent in his usage of the technical legal sense of $\sqrt{ }$ (של of the legal authority denoted by $\sqrt{ }$ is not defined by the use of one or more infinitives. This is replaced by the legal phrase כל כשר יחפץ יעשה to denote total freedom of action.

Where most of humankind is constricted by the actions which God has determined for them (ממן ועת לכל חפץ תחת השמים-3:1), the king is given legal authority to act as he pleases (על אשר יחפיץ יעשה -8:3). He is, as it were, the supreme embodiment of free will. The fact that the king has such authority from God also makes the command of the king almost a commandment. 51

In 10:5ff. Qohelet goes on to consider some of the practical consequences of שלטון allotted to rulers by God. He observes "an error which goes forth from the ruler (שליט)." Again, the term implies free will, for it suggests that the ruler has the

48 Hertzberg points to parallels in 2 Sam 7:14; Ps 2:7;20;21; 45 et al. (Prediger, 143) which suggest the special status of the king vis à vis God.

49 A. Hurvitz, "The History of a Legal Formula: kōl 'ăšer hāpēș 'ảsăh (Psalms CXV 3, CXXXV 6)," VT 32 (1982) 257-67.

50 Seow (Ecclesiastes, 280), citing Pss 115:3; 135:6, and related expressions in Isa 46:10; Jon 1:14; Dan 4:14, 22, 29, 32 (Eng. 4:17, 25, 32, 35). Plumptre (Ecclesiastes, 176) makes the observation that a similar phrase is used of God in Job 34:13.

51 Hertzberg understands God's oath having given the king almost a semi-divine status: "Gott hat dem König geschworen..., er ist persona sacra, 'von Gottes Gnaden'," (Prediger, 143). 
power not to act in the negative way which he does. 52 Just as wickedness and evil may be blamed on a misuse of של granted by God, inequity in life may to some extent be assigned to the wrong application of שve by the ruler to whom God gives it. This is not to undermine the often ambivalent nature of God towards the individual: many passages in Ecclesiastes assert such a concept (2:26; 5:19 [Eng. 18]; $6: 2 ; 7: 14,26 ; 9: 1)$. However, the misuse of fre or free will accounts for many of the problems observed by Qohelet in life.

Qohelet apparently dwells on this problem in 10:16, although $\sqrt{ }$ של itself does not appear. The licence enjoyed by the king is wrongly extended to the court because the king is too weak to enforce proper rule as God's subordinate: his princes "eat in the morning." By contrast the king who is brought up to rule, rules wisely: the course of events determined by God is maintained.53 The princes eat בעו which on one level means "at the appropriate time," but also has deterministic nuances. The king as divine agent has an obligation to rule as God envisions, despite the granted to him.

\section{(e) Qohelet as King (1:12-2:12)}

Qohelet too proclaims himself as a king (1:12). Hitherto, his reason for so doing has been considered in the light of the material goods which he enjoys in the course of his investigation into existence. ${ }^{54}$ A king has access to all possible

52 Whitley (Koheleth: His Language and Thought, 85) is probably correct in understanding $\supset$ in as asseverative: "Indeed it is an error which goes forth from the ruler," rather than comparative.

53 Glasser draws a parallel between the situation in 10:16 and the repercussions for a land in which the powerful are not answerable to the king in Eccl 3:16; 5:7-11 (Le procès du bonheur par Qohelet, 158). If correct, this is one more illustration of wickedness which may be attributed to a human misuse of

54 Kidner, A Time to Mourn, and a Time to Dance, 28. Crenshaw also cites the tradition of kings dispensing wisdom as a factor in Qohelet's adoption of a royal persona (Ecclesiastes, 70). E. Jones suggests that the literary device of the Solomonic persona "was really a means of expressing Qohelet's conviction that neither wealth nor wisdom provided the clue to the final meaning of life." (Proverbs and Ecclesiastes [London: SCM, 1961] 282). 
pleasures and comforts in life. The so-called "Solomonic identity" may or may not be incidental, but what is certain is that Qohelet claims to have acquired more wisdom and more material possessions "than all who were before me in Jerusalem $(1: 16 ; 2: 7,9) . " 55$

As I have argued elsewhere, the expression היה לפני is attested in the Hebrew Bible in connection with kingship as an idiom meaning "to be subject to." Qohelet therefore appears to be claiming not that he has become wiser and wealthier than all his royal predecessors (assuming that Qohelet $=$ Solomon, almost all interpreters have commented on the strangeness of this remark, since only David ruled in Jerusalem before Solomon), but that he has become wiser and wealthier than any of his subjects. ${ }^{56}$ Qohelet is ideally placed in the here and now to carry out his task of investigating existence, but his role as king rather than subject gives him an extra advantage: the one that is all important for a determinist- - he is free to carry out his search without divine interference. 57

The reason for Qohelet's adoption of a kingly persona therefore is not simply that a king enjoys access to material wealth. Any wealthy persons can replicate Qohelet's experiment by surrendering themselves to a life of pleasure. Indeed, Ginsberg argues that מֶָ 1:12; 2:12 might just as well be, and indeed should be, repointed as מלדף "landowner." 58 It is that the king has - authority to act on his own initiative rather than being subject to the deterministic force which appears to control the life of the individual. As a free agent, only a king is fully qualified to investigate existence: Qohelet's qualifications for the search are not

\footnotetext{
55 Emending בירושלם 1:16 as in 2:7, 9. This reading is attested by all the Versions and many manuscripts.

56 Rudman, "Qohelet's Use of 'לפני."

57 Murphy comments on the strangeness of the fact that Qohelet does not mention his own "kingly" status in 8:2-5 (Ecclesiastes, 83).

58 Ginsberg, Studies in Koheleth, 12-15.
} 
merely wisdom and wealth, but wisdom, wealth and kingship. That is to say, the finances to allow access to material things, the wisdom to distinguish profitable from profitless activities and the freedom from divine interference to conceive and carry out the search for what is good.

\section{Conclusion}

Although questions remain about Qohelet's worldview, his coherent use of $\sqrt{ }$ U and the implied parallel between God and a human king whose commands have the force of law, but who grants certain subordinates authority to act on their own initiative is a sophisticated and relatively successful attempt to explain the problems of human wickedness and social inequality in terms of determinism. It also explains the reasons why Qohelet portrays himself as a king, why he attainment of wisdom is necessary, and why Qohelet can advise his audience to pursue certain courses of action when he apparently believes that God determines all or most of the events making up existence. The presupposition to all of these problems is that God has apportioned some individual שלטון which gives him the ability to act on his own authority. On another level, the apportionment or not of (cf. 5:18 [Eng. 19] and 6:2) is another instance of the inscrutable nature of God's gifts to humanity, underlining their dependence on the deity for everything.

Seow's conclusion as to the chronological distribution of $\sqrt{ }$ in this legal/economic sense requires some qualification, however. Linguistic usage is highly subjective, both from the point of view of the speaker and that of the interpreter, but it would seem that even in the third century B.C.E., שלט could still retain the sense of "right of disposal", "delegated authority" or "proprietorship" which it had in the Persian period, and that in Hebrew this sense could not be applied to $\sqrt{ }$ aשר time, even though it may be true that this root occurs in some texts of the very late 
Hellenistic period (i.e. the Christian era) where we should expect to see $\sqrt{ }$. On linguistic grounds at least, the dating of the book of Ecclesiastes remains as problematic as ever, and Qohelet's use of $\sqrt{ }$ can be reconciled with a dating of that work to the third century B.C.E.. 


\section{Chapter 6 \\ Woman as Divine Agent in Ecclesiastes}

\section{Introduction}

Qohelet's attitude towards women has perplexed modern commentators in that he appears to take diametrically opposing views of that sex in the two passages in which they are mentioned in Ecclesiastes. Traditionally, Qohelet's assessment of women in Eccl 9:9 has been viewed as a positive one. 1 Over against this, most commentators would argue that the depiction of women in $7: 26,28$ is partially or wholly misogynistic, ${ }^{2}$ although a few scholars have attempted to mitigate the perceived misogyny of this latter passage by arguing that Qohelet refers in 7:26, 28 only to a "certain type of woman" against whom the sages warned, typified by some of the 'outsider' feminine figures who appear in the Book of Proverbs (Prov 2:16-19; $5: 3-14,20-23 ; 6: 24-26 ; 9: 13-18){ }^{3}$

Others have put forward solutions to this passage in which Qohelet quotes a negative view of women and then argues against it. ${ }^{4}$ Although such interpretations have the advantage that they resolve the dichotomy between this passage and 9:9, they present problems of their own and have not won full acceptance. The difficulties in the interpretation of the figure of the woman in 7:26, 28 are made still

\footnotetext{
1 Delitzsch, Ecclesiastes, 363-4. Plumptre, Ecclesiastes, 188.

2 Fox, Qohelet and His Contradictions, 238. Barucq, Ecclésiaste, 137.

3 Barton, Ecclesiastes, 147; Crenshaw, Ecclesiastes, 146.

${ }^{4}$ Lohfink's close analysis has been challenged on several counts: the meaning "bitter" (rather than "stronger") for מn in 7:26 seems assured from 1 Sam 15:32. Nor do the sages, though undoubtedly androcentric, have been misogynistic in the way that Lohfink envisions. The comparison of the mortality of woman with the occasional immortality of man in 7:28 presents contextual problems in the light of Qohelet's statements elsewhere $(1: 11 ; 2: 16 ; 6: 4)$ ("War Kohelet ein Frauenfeind? Ein Versuch, die Logik und den Gegenstand von Koh. 7:23-8:1a herauszufinden." in La Sagesse de l'Ancien Testament, 259-87). Murphy translates and interprets 7:28 as Qohelet's refutation of a traditional saying that women are worse than men (Ecclesiastes, 75-7). I feel that Murphy is right to view this passage within the wider context of 9:9 but is the affirmation of the saying that women are worse than men really the thesis that Qohelet has set out to prove ("that which I sought continually")?
} 
greater by the fact that there exists no real consensus on the locations of the beginning and end of the section in which she appears. ${ }^{5}$

Although some would argue that 7:23-24 are not connected with the verses which follow it, this article is written under the assumption that the passage in question extends from 7:23-29. The reasons for doing so are the reiteration of a variety of verbs denoting intellectual effort in $7: 23,25$, and the contextual continuity provided by the repeated use of the verbs מצא a this section continues into $8: 1$ is not considered here since its inclusion or otherwise does not significantly affect the outcome of this investigation.

\section{Translations}

7:23. I have tested all this by wisdom; I said, "I shall be wise", but it was far from me.

24. That which is far off and very deep, who can find it out?

25. My heart and I turned to know, to search, and to seek out wisdom and the sum, and to know [the wickedness of folly and] foolishness and madness. 7

26. And I find more bitter than death Woman, whose heart is snares and nets, whose hands are bonds; whoever God favours will escape her, but the 'sinner' will caught by her.

27. "Look, this I found," says Qohelet, "One to one to find the sum

28. That which 8 I sought continually I have not found: one man in a thousand I found, but a woman in all these I did not find.

29. Only see what I found-that God made humankind upright, but

\footnotetext{
5 A few scholars maintain that 7:23-24 is to be related back to the section beginning in 7:15 (Gordis, Koheleth: the Man and His World, 280-2; Murphy, Ecclesiastes,71-2).

6 Whybray, Ecclesiastes, 123. M. V. Fox \& B. Porten, "Unsought Discoveries: Qohelet 7:23-8:1a," HS 19 (1978) 26.

$7 \mathrm{I}$ follow the LXX and Syriac versions in my reconstruction of 7:25 and delete secondary gloss.

8 I follow the translation of Crenshaw here (Ecclesiastes, 144, 147) but relate back to אשכון in 7:27. Fox's argument for the emendation of אשש his assertion that Qohelet does discover a which he intends in 7:25.
} 
they have sought many sums."

9:9. Experience life with the woman you love, all the days of the life of your vanity which he has given you under the sun, all the days of your vanity: for that is your portion in this life and in your labour which you take under the sun.

\section{Text and Context}

\section{(a) $\operatorname{Eccl} 7: 26$}

In Eccl 7:23-29, Qohelet describes his search for Wisdom. His conclusion $(7: 23-24)$ is that it is unattainable. The parameters of his search are then defined more precisely: "I and my heart turned to know and to search and to seek out wisdom and the sum, and to know wickedness and folly, foolishness and madness" (7:25). Qohelet says more about his search for the "sum" $(7: 27,29)$, yet he also animadverts on a mysterious woman $(7: 26,28)$. Whybray comments on the "unexpected introduction" of this subject in 7:26 and goes on to remark "If this verse is in fact part of the section which begins in 7:23 and not the beginning of an entirely new section, it can only be understood as being intended to be in some sense a particular illustration of some point which has been made in 7:23-25."9

That such is indeed the case is accepted by most commentators: 7:23-25 and 26-29 share a common vocabulary and conceptualisation. Qohelet continually uses the language of seeking and finding, the verbs בקש ("seek") occurring three times (7:25, 28, 29) and ("find") eight times (7:24, 26, 27 [twice], 28 [thrice], 29). The תור ("search") also occurs (7:25). Qohelet denies the ability of any person to "find out" (מצ-7:24) wisdom and the sum, but he does "find" (מצ-7:26) that

9 Whybray, Ecclesiastes, 125. 
woman is "more bitter than death."10 Qohelet's heart (ב-7:25), the intellectual part of his character which is engaged in the search, makes a discovery about the equivalent part (לב) of the opposite sex, that it is "snares and nets."11

Fox seems to echo the scholarly consensus when he paraphrases the thought of 7:26 in the context of the preceding verses: "See where my painstaking research led me: to the knowledge that woman is a menace!"' 12 Whilst some have attempted to mitigate the harshness of modern accusations of misogyny by suggesting that Qohelet refers only to "a certain type of woman" (in which case we should presumably paraphrase "woman can be a menace" rather than "woman is a menace"), those such as N. Lohfink and K. Baltzer who attempt to refute all charges on Qohelet's behalf are in a still smaller minority.13

Qohelet aims his message at a male readership, for he advises his audience to "experience life with the woman you love" (9:9).14 The case of those who would assert that Qohelet in Eccl 7:26, 28 either refers only to some women, or that the apparently negative assessment of women in this section is a misinterpretation is strengthened by the fact that it does take into account the (largely) positive message of 9:9. I believe that the intuition of such commentators is correct.

Whybray's comment cited above, that 7:26 must illustrate some point made

\footnotetext{
10 Dahood appeals to the use of מרר in Aramaic and Ugaritic to posit the meaning "stronger" in this verse, a meaning also evident in Ezek 3:14 ("Qoheleth and Recent Discoveries," 308-9). The meaning "bitter" is, however, assured in 1 Sam 15:32, the only other occurrence in the Hebrew Bible of the terms מות מות together.

11 Delitzsch understands היאר היא מצודים as a copula, hence: "who is a snare, whose heart is a net..." (Ecclesiastes, 331-2), followed by Crenshaw, (Ecclesiastes, 146). I have followed the Masoretes' understanding of this expression, although no material difference to the thesis of this article is made if either is adopted.

12 Fox, Qohelet and His Contradictions, 242.

13 A summary of Lohfink's position may be found in his commentary (Kohelet, 57-9). Cf. K. Baltzer, "Women and War in Qohelet 7:23-8:1a" HTR 80 (1987) 127-32. Athalya Brenner devotes a brief paragraph to Qohelet's treatment of the subject of women in a recent feminist study on Israelite wisdom literature, but the position taken is strongly negative (A. Brenner "Figurations of Woman in Wisdom Literature" in A. Brenner (ed.), A Feminist Companion to Wisdom Literature [Sheffield: Sheffield Academic, 1995] 59-60).
}

14 Crenshaw, Ecclesiastes, 27. 
in 7:23-25, is a crucial one for the understanding of the purpose of the introduction of the mysterious woman in this verse. Whilst Qohelet has already reached a conclusion that wisdom is unattainable by human efforts and goes on to speak in more detail about "the sum" which he mentions in 7:25, he appears to say nothing concrete about "wickedness and folly, foolishness and madness."

The Hebrew phraseology of this last clause in 7:25 (רשש כסל והסכלות הוללות) is significant because part of it echoes the search which Qohelet undertakes in the socalled 'Royal Experiment' of 1:12-2:26. This is in addition to the verbs הס2 ("test"), and ("search"), which are shared only by these passages (הסנר occurs in 2:1; 7:23 and תור in $1: 13 ; 2: 3 ; 7: 25)$. Perhaps significantly, these two passages are the only places in which the term appears in the body of the book $(1: 13 ; 7: 27)$ as opposed to the prologue or epilogue $(1: 1,2 ; 12: 8,9,10)$. The terms ("foolishness") and ("madness") occur in such close proximity together מהולל elsewhere only in $1: 17 ; 2: 12,15$ whilst in the same passage the related term "mad" occurs in 2:2 and סכלות on its own in 2:3, 13. In the Royal Experiment, Qohelet describes his personal quest for knowledge of the world around him, specifically to "see what was good for human beings to do under the heavens the few days of their lives" (2:3). In the context of this search, Qohelet specifically describes laughter as "madness" (2:2) and the surrender of self to pleasure as "foolishness" (2:3). Couched among the many forms of enjoyment which he lists as experiencing are what he describes as "the delights of men", followed by the mysterious expression שרה ושדות

15 Although both occur in 10:13 describing the speech of a fool, they are not joined in the same catchphrase which is evident in $1: 17 ; 2: 12 ; 7: 25$. 
number of mistresses which Qohelet accumulated.16 Other than Qohelet's use of the noun אשי in $7: 26,28 ; 9: 9$, this would be the only other explicit reference to women in Ecclesiastes. Unfortunately, as Seow has recently pointed out, this interpretation rests on a misreading of a cuneitorm sign in the El Amarna texts. 17

Whybray argues that the text of this final clause in 7:25 is corrupt and that at least one of the words רשע כסל והסכלות הוללות is not part of the original text.18 However, there seems no reason to doubt the authenticity of סכלות "foolishness" and "madness." Both are part of Qohelet's vocabulary. Indeed, Qohelet outlines the parameters of his search in 7:25 in a way very similar to his statement in 1:17: I I applied my mind to know wisdom and to know madness and foolishness."19

If doubt is cast on anything in 7:25b, it must be on the phrase רשע כסל Qohelet says nothing about wickedness (רָּ ) anywhere in the royal experiment (the abstract noun is used elsewhere only in $3: 16 ; 7: 17)$. The noun כo is not otherwise found at all in Ecclesiastes (the abstract noun "folly" is represented by סֶ๊ in 10:6). It is tempting to delete רשי כסל רשל as an exegetical gloss (inserted to link 7:25 with the "wicked" woman in 7:26). By doing so, לדעת in 7:25b would have two direct objects (which should read סכלות ודוללות on the basis of $1: 17 ; 2: 12$ ) to balance חכמה וחשבון as the two direct objects of לדעת in 7:25a. The whole of 7:25 would then essentially be

16 The context, referring to the "delights of men", suggests that the reference is to women (cf. Cant 7:7). Most commentators therefore follow Dahood ("Qoheleth and Recent Discoveries," 307) and typically translate שרדה ושדות "many concubines", appealing to an apparent Akkadian gloss Saditum in E1 Amarna Tablet 369.8 and Ugaritic 5 th "mistress, lady". Cf. Whitley, Koheleth: His Language and Thought, 21-22.

17 In fact, G. Dossin's reading să dit tum(“Une Nouvelle Lettre d'el Amarna," RA 31 [1934] 127, line 8) is erroneous, should be read 5 G $q \dot{H}$ t t/and interpreted "cupbearer." Seow therefore links Eccl 2:8 with the postbiblical הד̦שִ, "chest, box" and the Akkadian Šaddu("Linguistic Evidence and the dating of Qohelet," 655.

18 Whybray, Ecclesiastes, 124.

19 I follow the Masoretic punctuation of 1:17 and read ודעת as an infinitive (so also RSV). The versions understand as an object of לדעת but this creates an awkward tautology. 
a restatement of Qohelet's intent which he sets out in 1:17.

Although assume the gloss to have been added before Ecclesiastes was translated), the earliest versions bear out part of my reconstruction of the text. The LXX reads, kai tov

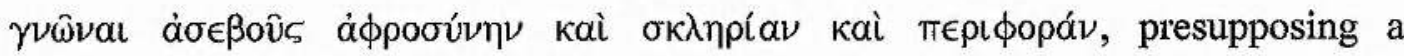
Hebrew text of ולדעת רשע: Toל וסכלות והוללות. The Peshitta meanwhile reads

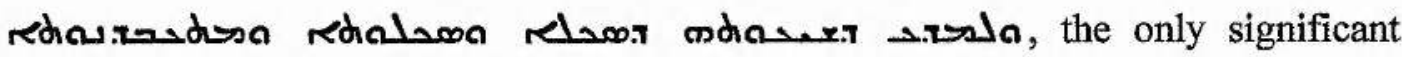
difference to the Hebrew text underlying the rendering of the LXX being that it

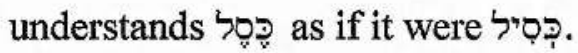

Because of its painstakingly literal Aquilan character, the LXX of Ecclesiastes can be useful in reconstructing a difficult text. The evidence of the LXX supports the deletion of the definite article from os and the LXX, Peshitta and Targum all support the addition of the conjunction to הוללוח. The Hebrew text underlying all of these also lends some credence to the hypothesis that ho רשי a a conjunction may have been added before an original for all of them are witness to a strange text in which the verb ידע is followed by a genitive construction, itself followed by the two direct objects which we should expect to find according to 1:17. The deletion of the conjunction from הוללות which underlies the Vulgate's rendering: impietatem stulti et errorem imprudentium, and the MT may be understood as subsequent attempts to make sense of this earlier Hebrew text by rendering the four nouns as double accusatives after a verb of cognition.

In addition to considerations stemming from the wider context and the versions, there is further evidence supporting the deletion of bos the terms in which Qohelet describes the woman of 7:26 and her male victims precludes an understanding of either as "wicked." 


\section{(i) Qohelet's Vocabulary of Entrapment}

Three words suggesting entrapment are associated with the woman in Eccl 7:26. The woman's intellectual/emotional side (לב) is characterised by the terms

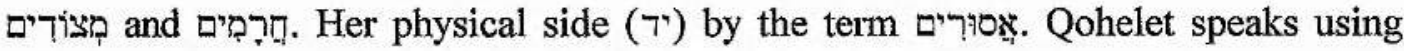
very similar entrapment vocabulary in 9:12. There, humankind are portrayed as

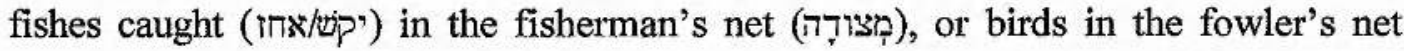
(חפ). In the latter case, the hunter is divine, rather than human: Murphy rightly points out the parallel between the "evil time" (עת רע) mentioned in 9:12 and the catalogue of times which are determined by God in 3:1-8.20

Some of these words are relatively rare in the Hebrew Bible, and an examination of the contexts in which they occur elsewhere yields some surprising results.

$$
\text { מִצוֹדָה/מָצוֹד }
$$

The term פמצר "net, prey" occurs four times in the Hebrew Bible outside the Book of Ecclesiastes (Ps 66:11; Ezek 12:13; 13:21; 17:20). In three of these occasions (Ps 66:11; Ezek 12:13; 17:20), it has its primary meaning of "net". In all three example, the usage is a figurative one, illustrative of Yahweh's judgement. On the one occasion when it means "prey" (Ezek 13:21), it refers to the people of Judah as the prey of a foreign power through the acquiescence of Yahweh: again, it is a reflection of divine judgment.

The term דị "net" occurs only twice outside Ecclesiastes (Prov 12:12; Job 19:6). Unfortunately, the text of the former is dubious, and its use there cannot be verified, but in Job 19:6, the context is once again of Yahweh as Job's hunter. It would appear from the examples which we find that, outside Ecclesiastes, both terms

20 Murphy, Ecclesiastes, 94. 
are used in a context in which God is the hunter of the (sinful) person.

\section{חרם}

The term חרים which appears in Eccl 7:26 refers to a fisherman's dragnet (as opposed to a מכמרת or casting net which is spread on the surface of the water-Isa 19:8). Outside Ecclesiastes, the term חרים appears only in the prophets (Ezek 26:5, 14; 32:3; 47:10; Mic 7:2; Hab 1:15, 16, 17).

Of the eight times which this term is used outside Ecclesiastes, only one occurrence uses חר in a figurative sense of a weapon used by evil people to ensnare each other (Mic 7:2). Even here, it has been suggested that חרט may be derived from חרם (I) and mean "destruction." משטוח לחרמים/משטח חרמים "place for the spreading of nets (to dry)" either as an image of divine judgment (Ezek 26:5, 14) or blessing (Ezek 47:10). The remaining four (Ezek 32:3; Hab 1:15, 16, 17) concern the use of the itself as a figure of divine judgement. G. Giesen comments concerning this usage that "the 'divine' net in the hand of Yahweh, or used by others at his behest is a symbol of power and sovereignty." 22 In Ezek 32:3 the term is illustrative of Yahweh's power over Pharoah, who is depicted as a crocodile hauled out of the water in Yahweh's חרם. In Hab 1:15, 16, 17, Yahweh has allowed the Babylonians to become so mighty that they can catch other nations like fish. In this example, the Babylonians effectively act as God's viceregents, punishing the sins of the surrounding nations, including Judah.

אסור

The term "fetter" is a more neutral one, generally used in a literal rather than figurative sense. In Judg 15:14 the plural is used of the fetters binding Samson,

21 A. S. Van der Woude, Micah (Nijkerk: Callenback, 1976) 244.

22 G. Giesen, "דרז (II)," TDOT 5.202. 
and in Jer 37:15 in the phrase בית האסור can sometimes be used of divine chastisement (Job 36:13; Ezek 3:25; Ps 149:8). The Qal passive participle is also found in Eccl 4:14.

\section{(ii) Woman as Divine Agent}

Qohelet describes the times (עת) which go to make up existence in terms of a divine fisherman or fowler catching human beings in his nets in 9:12. I follow Fox in linking this passage to the series of times enumerated in 3:1-15 and in reading that passage with a deterministic slant. The terms in which the heart of the woman is described in 7:26 suggest that she is the agent of a deterministic force. Where מצודה occurs in 9:12 for God's nets with which he harvests human beings in order to impose the appropriate event in the individual's life, the related term מצוד describes the nets with which the woman ensnares men. Outside Ecclesiastes, both are predominantly used in the context of a divine, or divinely appointed, hunter ensnaring sinful human beings. The same applies to the term חסור חרם may be a more neutral term, the root from which it comes, as we have seen, can occasionally be used in this sense. If 3:1-15 is understood as a deterministic text as well as $9: 12$, the depiction of the woman as representative of an inescapable divine force would be consonant with Qohelet's statement that there is "a time to love" $(3: 8)$.

Although Qohelet's reaction to the woman in 7:26 is strongly negative, she cannot be deemed "wicked" as such since her whole raison d'être is to perform God's will by punishing those who have sinned. Her role as an instrument of divine judgment on humanity is emphasised in 7:26: "those who are good before God will escape from her; the sinner will be caught by her." Unlike Israelite Wisdom's traditional portrait of the feminine outsider, the "sin" of her victim lies not in the act 
of following her (the woman of 7:26 appears to be morally neutral). Rather; it is preexistent in the man who encounters her. Moreover, the victim is unable to exercise free will in the face of the woman's power. He is entirely dependent on God as to whether he is caught or whether he escapes.

The dragnets (חרמים) with which the woman is associated suggest the efficiency of the woman at the task which God has allotted her. Again, unlike Israelite Wisdom's negative portraits of the feminine outsider, it is not the occasional stray who succumbs to her allure, but whole shoals of the sinful. In the previous section, Qohelet comments that "there is not a just man on earth that does good and does not sin" (יעשה טוב ולא יחטאו-7:20), preparing us for Qohelet's statement that one "who is good before God" (טוב לפני האלהים) will escape her, whilst she will ensnare "the sinner" (חוטא). The ubiquity of sin among men (as suggested by 7:20 and implicit in 7:29) as well as the scale of operations evident from her dragnets (הרמים) forces the conclusion that the image of the woman is intended universally: it is for this reason that 7:26 should not be translated, "More bitter than death is the (sort of) woman who..." as a foil to Qohelet's apparently positive statement in 9:9. Rather, she seems representative of her gender and the role in God's creation which Qohelet envisions for it.

\section{(iii) $7: 26$ as Allusion?}

Woman as Qohelet depicts her appears remarkably dissimilar to the traditional Israelite portraits of the feminine outsider which appear in the Book of Proverbs $(2: 16-19 ; 5: 3 \mathrm{ff}, ; 7: 5-23 ; 9: 13-18)$. The woman of Eccl $7: 26$ is more a huntress of the masses than a temptress of the individual. She is an everywoman figure who works for rather than against God in her enactment of judgement upon those who have sinned. Nothing suggests that she encourages previously "good" 
people to $\sin$.

The sole similarity between Qohelet's portrait of the woman in Eccl 7:26 and those in other Israelite Wisdom texts lies in the fact that all appear in the context of the search for wisdom. The זרה woman and Dame Folly lure their victims from the path of wisdom to commit an act of folly which inevitably results in an early death.23 No such fate, however, is suggested for the consort of the woman of Eccl $7: 26$. She herself is the punishment, though for what is not specified.

In Ecclesiastes, $\sqrt{ } \times \boxminus \Pi$ "sin" occurs eight times $(2: 26 ; 5: 5 ; 7: 20 ; 7: 26 ; 8: 12 ; 9: 2$; $9: 18 ; 10: 4)$. From these examples, it is evident that Qohelet very often uses terms derived from this root not so much to denote a simple moral transgression, but rather the act of displeasing God in some form, which may not be obvious to the doer of this action. 24 The majority of commentators hold that this is true particularly of טוב לפני $2: 26$, in which the term ("sinner") occurs in opposition to the phrase טוב לפני האלהים and ("good before God").25 This opposition between האלהים occurs elsewhere in Ecclesiastes only in 7:26 in the context of those who are fated to fall victim to the woman and those whom God will allow to escape her. This forces the conclusion not that the woman's victims are immoral, but that they have displeased God.26 The woman's victims therefore cannot be designated as "wicked" (although some may be). If neither the woman nor her victims have committed a

23 Death as a consequence of following the זרoman is mentioned in Prov 2:18; 5:5; 7:27. In Prov 9:18, the passage in which "Dame Folly" appears, the phraseology is much sharper; the woman's house itself is the country of the dead, an outlying annex of Sheol (C. H. Toy, Proverbs [Edinburgh: Clark, 1899] 191).

24 This idea is particularly evident in 4:17 (Eng. 5:1).

25 For a detailed treatment of this subject, cf. Gordis, Koheleth: The Man and His World, 227-28.

26 Murphy, Ecclesiastes, 76; Crenshaw, Ecclesiastes, 146. Whybray, Ecclesiastes, 125. Most recently, this position has been adopted by de Jong ("God in the Book of Qohelet: A Reappraisal of Qohelet's Place in Old Testament Theology," VT 47 [1997] 157). As of this writing, Whybray appears to have retreated from the position which he takes up in his commenatary and now does assign a moral meaning to the two expressions ("Qoheleth as Theologian," in A. Schoors (ed.), Qohelet in the Context of Wisdom [BETL; Leuven: Leuven University/Peeters, 1998] -forthcoming). In this, he follows Lauha (Kohelet, 58). 
moral transgression, the secondary nature of reasonably assured.

\section{(iv) The Purpose of the Woman}

If the woman's victim is free from moral guilt, we must ask the purpose of the woman's appearance. Possibly she is a symbol of the arbitrary nature of the deity's intervention in life (as in 9:11-12). This is not, however, illustrative of any point in 7:23-25.

Whatever the reasons for incurring God's displeasure, it would appear that the חוטא is punished with a life tightly circumscribed by God. His fate is "...toil (ע) (עין): to gather and to heap up to give to one who is good before God" (2:26). Love (3:8) is also a form of עבין doled out by God (3:10), one of the times apparently allotted "so that nobody may find out the work of God from beginning to end" (3:11). This appears to bear out 2:26, where we are told that God gives wisdom to those who are חוב לפני האלהים, denying it to the woman may therefore have a role in preventing the sinner from discovering "the work of God" (exactly the kind of information which Qohelet seeks $[7: 13 ; 8: 17])$. Qohelet, when speaking of the pleasures, including women, associated with the kingly lifestyle in the 'Royal Experiment' stresses that he maintained his hold on wisdom $(2: 3,9)$ despite their designation as "folly and madness" (1:17; 2:3, 12 cf. 7:25). Qohelet supposes such pleasures as the woman embodies as antithetical to wisdom. 27

Qohelet's viewpoint in his assessment of the woman is that of the sage, the seeker after wisdom. Escape from the woman is therefore a mark of divine favor. Though one who falls victim to "time" (ע) may not find the work of God, he may

27 Crenshaw argues that priv in 2:2 refers only to lighter side of joy: "Qohelet dismisses frivolity as incompatible with intelligence and psychological stability" (Ecclesiastes, 77), but the same might be said of all joy, for Qohelet dwells on the sadness of the sage in 1:18; 7:4. 
find contentment. Qohelet's advice to the "sinner"- the vast majority, if not all of his audience, is to accept the decision of God with equanimity.

His assessment of the woman as "more bitter than death" is emphasised as a personal one ("וצא "I find..."). It does not appear to be so for her quarry. The reason for Qohelet's personal assessment of the woman as "more bitter than death" has never been satisfactorily explained: presumably God has permitted Qohelet's escape, so why such a harsh judgement? A possible solution to this problem will be offered presently ("Woman and the Sum").

\section{(b) Eccl 9:9}

There is no conflict between Qohelet's view of the woman in 7:26 and 9:9. In the latter passage, Qohelet states: "Experience life with the woman you love all the days of the life of your vanity, which he has given you under the sun, all the days of your vanity: for that is your portion in this life, and in the labour which you take under the sun." Qohelet sees typical life with the woman as reflective of the of the overall vanity of existence. Yet he also advises his (male) audience to "experience life" with her. Man's love of Woman is unavoidable: no choice is suggested here as to how Man feels about her (as indeed there is none in 7:26), although Man can perhaps embrace his fate enthusiastically or not. God's hand in the matter of love between the sexes, illustrated by the imagery of the divine nets in $7: 26$, is reflected in the fact that Woman is called the "portion" of Man in life. 28 For Qohelet, love is allotted by God as part of "the work which is done under the sun." It is potentially a positive thing for the one who experiences it: 9:9 suggests that Woman may be a source of הבל companionship and support through life. The gift which God gives is one of

\footnotetext{
28 Such an interpretation is supported by the Oriental Ketib in 9:9 which reads היא חלקד "she is your portion" for הוא "it is your portion." Howeverly refers to (joyful) life with the woman: thus, Murphy (Ecclesiastes, 93), who remarks, "the usual irony is present; one is to accept this 'portion,' but without forgetting the perspective of 'vain life' and its 'toil.'”
} 
"vanity" however, like the less pleasant one which he gives to the afwj in 2:26. Qohelet seeks that which is not, explaining why he considers escape from the woman in 7:26 a mark of divine favour.

Qohelet's view of Woman is at once restricting and liberating. Like Man, she is a being controlled by the deity. Yet she is also an extremely powerful semi-divine figure. Her weapons are allocated to her by God, and Man has no defence in the face of them. God may pull the strings from heaven, but on earth, it is Woman who is the master. In a sense, Qohelet's world view is one in which Eve has ganged up with God against Adam.

\section{(c) $\underline{\operatorname{Eccl} 7: 27-28}$}

\section{(i) Humanity and the Sum}

On the basis of the entrapment imagery associated with the woman in 7:26, the scholarly consensus has hitherto been that the woman of this passage is an archetype of wickedness. This alone has provided the rationale for the elliptical interpretation of the verb מצא in 7:28 as "found trustworthy."

In 7:27, Qohelet describes the counting process by which he hoped to "find" the "sum". The Hebrew term which lies behind this translation is identified with Wisdom in 7:25. A possible connection between humanity (Man and Woman) and the מצא in in underlined by the repetition of the verb's statement that "one man in a thousand have I found, but a woman in all those have I not found" (7:28).

I would argue that this repetition is significant. Qohelet speaks of failing to "find" the (described as "that which I sought continually"), and then, in what appears to be an explanation of his statement, remarks on his inability to "find" human beings. The human connection is reinforced by the appearance of the in 
7:25 among the human qualities of "wisdom...foolishness and madness" which define the internal state of all human beings and their external actions. 29 This human element is further suggested by its parallel usage to wisdom (חכמה), knowledge (דער) and work (מעשה) in 9:10. Qohelet considers that the may be discovered by an investigation into humanity, their motivations and their deeds - this is also implied by Qohelet's statement that he intended "acquainting my heart with wisdom...to lay hold on folly, till I might see what was that good for humankind which they should do under the heavens..." $(2: 3)$.

Commenting on Whybray's assertion that the generally accepted elliptical interpretation of מצא as "find trustworthy" when applied to Man and Woman in $7: 28$ is "merely a guess", Murphy states "it is the context (vv. 26 and 29) which justifies the assumption that the specific meaning deals with moral conduct." ${ }^{30}$ However, if the context which 7:26 provides is now of the woman acting as a divine agent not against men who have committed a distinct moral transgression, but who have "displeased God" in some indefinable way, the justification for a moral understanding of the "finding" of human beings in 7:28 becomes more tenuous, and an alternative interpretation must be sought.

\section{(ii). The Language of Seeking and Finding}

In speaking of the חשון Qohelet never uses the verb Instead, the verbs מצא (7:24, 26, 27 [twice], 28 [thrice], 29; 9:10) occur. The other significant object of these verbs as concerns Qohelet's search is "the work of God"//"the work which is done under the sun" $(3: 11 ; 8: 17)$.

29 Crenshaw states: "Coupled with wisdom, hes"bonconstitutes the substance of human thought, the sum total of all knowledge" (Ecclesiastes, 145). Whybray follows a similar course in his understanding of it as "the sum of things" (Ecclesiastes, 124).

30 Whybray is alone in insisting that the verse "does not state what it is that the speaker has sought, and which he has, or has not, found." (Ecclesiastes, 127); cf. Murphy, Ecclesiastes, 77. 
I follow the positions of Gordis, Fox and Murphy that "the work of God" and "the work which is done under the sun" are one and the same (an important point if a case is to be made for determinism). ${ }^{31}$ Qohelet sees (ראה) "all the work of God" in the course of his investigation $(8: 17)$ and recommends his followers to do likewise (7:13), but this work is impossible to "find out" (מצ-3:11) or "know" (עיד-11:5). Likewise, Qohelet and others can see (דאר-1:14; 2:17;4:3) "the work which is done under the sun", but Qohelet denies the ability of humankind to "find out" (אצ-8:17) this work.

Thus, both "the work which is done under the sun" and "the work of God" appear to be the objects of Qohelet's search, along with the are not to be identified exactly, though that is certainly the implication of Whybray's definition of the "זשבון as "the whole of that which is": it does, however, seem reasonable to suppose that finding the other declared objects of Qohelet's search. Indeed, Murphy's comment that 3:14 "whatsoever God does, it shall be forever: nothing can be added to it, nor anything taken from it" is about "the immutability of the divine deed, not word" and is thus to some extent divorced from possible antecedents in Deut 4:1-2; 13:1 would appear to support the idea that Qohelet might have envisioned "the work of God" as a 32 32 Qohelet's intent, however, is not to alter it but to count it.

In the context of his search, whether he chooses to denote the object as "the work which is done under the sun", "the work of God" or "the sum", Qohelet uses

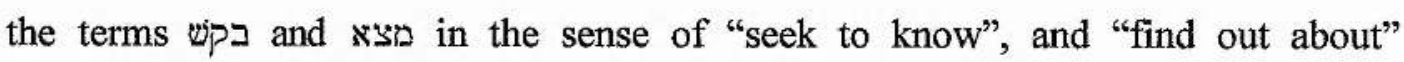

31 Gordis, Koheleth: The Man and His World, 298-9; Fox, Qohelet and His Contradictions, 175; Murphy, Ecclesiastes, 13.

32 Murphy, Ecclesiastes, 35. 
respectively.33 This is reflected in the parallel usage of the verbs and a $7: 25$ and of ידע 8:17. When Qohelet speaks of "seeking" and "finding", he never uses it in a moral context. 34

In 7:28, Qohelet speaks of "finding" a man, but not "finding" a woman on his quest for knowledge about "the sum." Qohelet seeks knowledge of the world around him, and specifically what is "good for people to do under the sun" (2:3) by finding "the work which is done under the sun." In order to do this, he considers by turns the cases of other individuals in order to build up his world view, drawing appropriate conclusions with which to illuminate his thinking. Thus, having experienced the life of a king (2:12), he examines the situation of "the man whose labour is in wisdom and in knowledge and equity" who may leave his wealth to an unworthy person $(2: 21)$, he considers the oppressed as a group (4:1), the solitary driven individual with no-one to inherit the fruits of his toil (4:8), the young man who attains rank but is ultimately despised (4:13-16), the man who loses his money in an unlucky venture so that he cannot leave it to his son (5:12-17 [Eng. 13-18), the man who is given riches and the ability to enjoy them (5:19 [Eng. 20]), the man who is given riches but no ability to enjoy life, although he has every advantage including children and longevity $(6: 2-6)$. He cites the case of the righteous man who dies young and the wicked man who has an extended life span (7:15), the man who "rules over another to his own hurt" (8:9), the poor wise man who is despised despite his wisdom (9:13-18), and the situation in which servants appear to have greater status than their masters $(10: 7)$. These examples which he gives are "real life" cases which he examines in the course of his quest for "wisdom and the sum" (7:25). From these

33 Cf. Whybray's understanding of the verb מצא as "find out" (Ecclesiastes, 74); Crenshaw's translation "fathom" (Ecclesiastes, 91, 153), or that of Gordis, "discover" (Koheleth: The Man and his World, 156, 186).

34 This observation is also made by Lohfink ("War Kohelet ein Frauenfeind?" 280-81) and Baltzer ("Women and War in Qohelet 7:23-8:1a," 130). 
examples he attempts to discover an underlying pattern which might tell him "that which is good for people to do under heaven the few days of their lives" (2:3). Thus, the 'finding' of individual people is intimately linked with the enquiry into the it is the only way in which Qohelet, who cannot take for granted those beliefs touted as certainties by the sages, can hope to comprehend the nature of existence. ${ }^{35}$

Just as Qohelet "sees" (ראה) "the work of God" or "the work whis done under the sun", he "sees" these people who make up his worldview. Just as he fails to "find" (מצא) his object, whether this be termed "the sum", "the work of God" or "the work which is done under the sun", he fails to "find" human beings. Essentially, Qohelet uses the term "see" for the consideration of events and people: "find" has to do with the acquisition of knowledge from this process. Yet human actions are tainted by the irrational $(2: 3 ; 9: 3)$ and the behavior of human beings leaves Qohelet bewildered $(2: 2,15 ; 4: 4,8 ; 5: 10$ [Eng. 11$] ; 6: 7 ; 9: 16 ; 10: 7)$. Because of this, the individual may be as unfindable as "the sum."

\section{(iii) Woman and the Sum}

Qohelet's attempt to discover the humanity as a whole, their motivations and actions as defined by wisdom and folly: those characteristics of humanity, in other words, which reside in the mind (לב) of the individuals which he considers.

This search is conducted by Qohelet's application of his own mind (לב) to certain features of existence. The term לב is used with a first person suffix 18 times in Ecclesiastes (1:13, 16 [twice], 17; 2:1; 2:3 [twice], 10 [twice], 15 [twice], 20; 3:17, $18 ; 7: 25 ; 8: 9 ; 8: 16 ; 9: 1)$. Once again, there is a concentration of usages in the 'Royal

35 Such cases may be "hypothetical" or "an example from daily observation" (Crenshaw, Ecclesiastes, 110), but even if the former, Qohelet could not mentally reproduce all possible scenarios which may occur in a human existence. Such hypotheticals would also still have to be based on some form of knowledge gained from observation. 
Experiment' (12 uses), finding an echo in 7:25. Yet Qohelet by this means also considers and reaches conclusions about the hearts and minds (לב/לבב) of other people, both individually and as groups $(2: 22,23 ; 3: 11 ; 5: 19$ [Eng. 20]; 7:4 [twice], $7 ; 8: 5,11 ; 9: 3$ [twice]; 10:2 [twice]; 10:3).

Qohelet reaches a conclusion about the לב of Woman in 7:26; the counterpart to Qohelet's heart with which he embarks on his quest for "the sum." It is a mass of traps (חרמים/מצודים) ready to close on the unwary. Those who are caught by the woman may obtain the chance for a closer investigation of her, but as far as Qohelet is concerned, the best that the sage can hope for is not that the male individual may 'find' the woman: that way lies entrapment. Rather, God's favor lies in escape and the hope that God may grant the sage "wisdom, knowledge and joy."

Qohelet's statement therefore, that "a woman...I did not find" works on two levels. On the one hand it suggests his objectivity and that he retained his wisdom (as in $2: 3,9$ ), but on the other, it signals failure to know the sum totality of human motivation and action which is denoted by the "the work which is done under the sun." If failure to find the חששבון is explained by Qohelet's inability to "find" men and women, we must assume both to be necessary for a successful resolution of his search.

Essentially, Qohelet finds himself in what might be called a "Catch 22" situation. Even were Qohelet able to "find" more than a miniscule proportion of the male population, the finding of even one woman, equipped as she is with her divine weaponry, would mean the end of the search for the חשון. In Qohelet's classic consideration of Sheol in 9:10, he states: "Whatever your hand finds to do, do mightily, for there is no work (מעשה), no sum (חשבון), no knowledge (דעת), no wisdom (חכמה) in Sheol where you are going". Woman has prevented Qohelet's 
object which is stated in 7:25 to be "to know (לדעת)...wisdom and the sum (רששבון) חכמה ")", and which is described in 8:17 as "the work (מעשה) which is done under the sun". Because of the woman of 7:26, Qohelet experiences a form of death-in-life, a grim foretaste of Sheol. Little wonder then that he can say on a personal level " $I$ find more bitter than death...Woman". The dead are aware of nothing (9:5): Qohelet lives on with the experience of failure and no expectation of better things after death.

Whether the individual is trapped or allowed to escape by God, the integrity of the remains intact. Qohelet's earlier assertion that "(Humankind) cannot contend with one stronger than them" $(6: 10)$ is proved correct. Woman forms a divine defence against attempts to find such knowledge as Qohelet seeks. God may give "wisdom, knowledge and joy" to the one who escapes the woman but this is not the same thing as the "the sum" which Qohelet wishes to attain.

\section{(d) Eccl 7:29}

The meaning of 7:29 remains obscure, and commentators have attempted to deal with it in a variety of ways. Bearing in mind the apparently co-extensive nature of the "the work which is done under the sun" and "the work of God", Qohelet's experience in seeking the first has allowed him to conclude something about what God has done: it is that "God made (עשה) humankind pleasing but they have sought many

The MT's, תחד has the general idea of "intrigues." It is difficult to see how such a meaning fits in with the rest of the passage. Crenshaw remarks "Qohelet's search for the sum...has failed, but humankind's search for many devices or intrigues...has succeeded admirably."36 Yet it is not the verb מצא w w w w which is used, suggesting that humankind have failed in their search for חשבנות. Fox, following

36 Ibid., 148. 
Ginsberg, appears to see the object of humankind's searching as essentially the plural

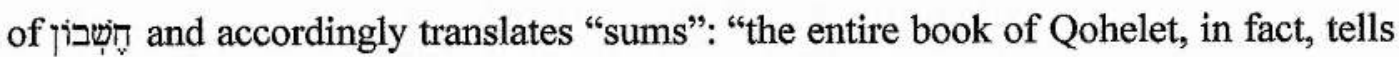
of his search for hišsebonot"37 I think the instinct of both is correct: they are supported by other commentators who have argued at least for a double meaning for תhich takes into account the context of Qohelet's search for the

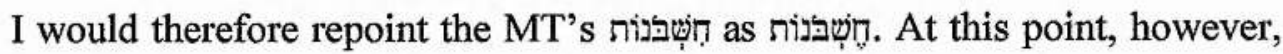
another difficulty arises. Fox's argument that Qohelet searches for חשכנות meets with a problem because there is only one mentioned by Qohelet. However, if I am on the right lines in suggesting that the nem is ultimately made up of the thoughts and actions of humanity (i.e. "the work which is done under the sun"), it may be that Qohelet considered it to be capable of change. When people die, they go to the place where there is no sun." When people are born, they become part of the "The work which is done under the sun" may thus be different at one point in history than another. If the חששבנות רבים is, as "many sums" stretching back into the past: "those which were."

Alternatively, it may be that Qohelet is simply playing on words, so that חששבוגות refers to (concrete) accounts of existence formed by many individuals. Each, like Qohelet, hopes that their account will balance with the true (abstract) "account" par excellence. That they, like Qohelet, have failed in this regard would be suggested by the 3pl perfect form בקשו 7:29-Qohelet is saying that he is merely the latest in a long line of seekers after a

37 Ginsberg (Qoheleth, 103). Fox points to the use of the key term שp in 7:29 as in 7:25, 28 (Qohelet and his Contradictions, 243). I do, however, disagree with Fox's assertion that 'simple, intellectually direct'. The argument of Whybray, who points to the idiom 'to be רשי in God's sight' in the sense of 'to be pleasing to God' seems to better fit the context (Ecclesiastes, 127).

38 Lohfink, Kohelet, 58-9; Zimmerli, Der Prediger, 209-10. 


\section{Conclusion and Summary of Qohelet's Thought}

In 7:25, Qohelet considers humanity and their actions as defined by the terms "wisdom and the sum...foolishness and madness." His failure in this endeavour is signalled by the introduction of Woman, the divine agent protecting the Elsewhere, Qohelet describes how "the work of God" is protected by the allocation of ענין Love is both of these: the one who has displeased God is caught by the woman and once caught there is no escape (9:9). Only God can determine the fate of the male individual with respect to this woman.

We may assume that Qohelet did escape the woman, but her existence nevertheless has serious consequences for Qohelet's search. Not only does she protect "the work of God" from the sinner; she ensures that the counting process (of people, their motivations and actions) by which Qohelet hoped to find the (7:27), which appears to be linked with "the work of God"/"the work which is done under the sun", is doomed to failure. Qohelet finds only a small proportion of Mankind whose actions make up the חשבון. He is unable to find Womankind (7:28), for she is too dangerous to approach-God's favour is demonstrated not in finding Woman but in escaping her (7:26). Qohelet's conclusion (7:29) ironically plays on this hunt for "the work of God." He finds that that God did not intend humankind to search for the but that, like himself, they have done so throughout history. 


\section{Chapter 7 \\ "A Time to Laugh": Qohelet and Human Joy}

\section{Introduction}

It would be fair to say that the joyful imperative is the one positive conclusion that Qohelet reaches during his investigation into "what was that good for humankind, that they should do under the heaven all the days of their life" $(2: 3)$. Yet Qohelet initially discounts pleasure and its material trappings as a legitimate good for human beings $(2: 1-2,11) .1 \quad$ It is the predetermined nature of life which forces Qohelet to revise his initial conclusions about the value of pleasure. Thus, Qohelet frequently uses the phrase "מאין "there is nothing better" to qualify his recommendations to enjoy the material benefits which life can offer $(2: 24 ; 3: 12,22$; $8: 15) \cdot{ }^{2}$

Whybray considers the immediate contexts of the passages in which Qohelet affirms pleasure as a positive good $(2: 24-26 ; 3: 10-15 ; 3: 22 b ; 5: 17-19 ; 8: 14-15 ; 9: 7-$ 10; 11:7-12:1). ${ }^{3}$ From these passages, several things become clear. The first, and most notable is that the opportunity and the ability to take pleasure in the material benefits of life is a gift granted by God himself. The verb נתן (2:26; 5:17-18; 8:15; 9:9) and the derived noun מתת $(3: 13 ; 5: 18)$ occur with some frequency in these passages. ${ }^{4}$ Yet Qohelet also offers other reasons which are essentially related to this

1 Delitzsch, Ecclesiastes, 233-34, 243; Murphy, in particular, stresses that Qohelet's experiment is not with mindless joy, but with "the good life" (Ecclesiastes, 17-18). Whybray explains Qohelet's failure to find satisfaction in this experiment to the fact that he seeks it independently: joy can come only at the time which God determines for it (Ecclesiastes, 52). A very similar view is adopted by Hertzberg (Der Prediger, 81-82).

2 Murphy, Ibid., 26, 39, 53.

3 Whybray, "Qoheleth, Preacher of Joy," 88. This pattern is followed in the main by de Jong ("A Book on Labour: The Structuring Principles and the Main Theme of the Book of Qohelet," JSOT 54 [1992] 110).

4 Whybray, Ibid.. 
one: that one's lot in life is unchangeable and must be accepted $(2: 26 ; 3: 14 ; 3: 22 \mathrm{~b}$; $5: 18 ; 9: 9), 5$ that life is fleeting and must therefore be made the most of $(5: 17 b ; 9: 9 b$; $11: 9 ; 12: 1 \mathrm{~b}), 6$ and similarly that the present must be enjoyed because future events are concealed from human beings $(3: 11 ; 3: 22 b ; 8: 14){ }^{7}$

Although it is doubtful that Qohelet regards all of these things as "positive incentives" rather than "depressing considerations", the essential points of Whybray's analysis of Qohelet's attitude to pleasure are sound.8 In Qohelet's view, God does indeed play a pivotal role in the allocation of pleasure as the vast majority of commentators accept. This in itself is indicative to some extent of a deterministic view of life on Qohelet's part. However, can pleasure as Johnston, Whybray and others suggest, really be considered solely as being within "the gift of God"?9

\section{Human Efforts to Attain Joy}

Qohelet's philosophy of life is notable in that human attempts to achieve contentment appear from the very beginning to be doomed to failure. In $4: 8$, he remarks on the case of the individual, without a companion, who labours purely for himself: "there is no end of all his labour, nor does he ask, 'For whom am I labouring and depriving myself of good things?" Such a person is symptomatic of the general dissatisfaction of humanity with the material benefits of life (a dissatisfaction which

\footnotetext{
5 R. K. Johnston states: "Man's pleasure depends on God's good pleasure, and the divine action cannot be neatly categorized or programmed by man" ("'Confessions of a Workaholic': A Reappriasal of Qoheleth," $C B Q 38$ [1976] 25). Cf. de Jong ("God in the Book of Qohelet: A Reappraisal of Qohelet's Place in Old Testament Theology," 163), who states likewise that "the enjoyment of life has to be given by God."

6 Glasser, Le procès du bonheur par Qohelet, 168; Barton, Ecclesiastes, 184-85.

7 Gordis, Koheleth: The Man and His World, 238. Crenshaw sees the expression ("after him") as referring to what happens to oneself after death (Ecclesiastes, 105).

8 Whybray, "Qoheleth, Preacher of Joy", 88.

9 Whybray, Ibid., 89; Ecclesiastes, 52; Johnston, "Confessions of a Workaholic," 25; Crenshaw, Ecclesiastes, 90; Murphy, Ecclesiastes, 1x.
} 
Qohelet himself has, ironically, experienced).10 The theme of acquisitiveness and the concomitant dissatisfaction with that which is acquired is one which is close to Qohelet's heart, for he dwells on it in an extended passage (5:9-16 [Eng. 10-17]).11 In 5:9-11 he states:

\begin{abstract}
He that loves money shall not be satisfied with money, nor he that loves abundance with increase: this is also vanity. When goods increase, their consumers increase but what good is there to their owners except to look at them with their eyes? The sleep of a labouring man is sweet, whether he eats little or much: but the rich man's abundance will not allow him to sleep.
\end{abstract}

The paradox of toiling to achieve a goal, which then proves to be unsatisfying in some way, yet continuing to labour nevertheless is highlighted in the introduction to the book in 1:4-8. There, Qohelet uses a series of analogies from the natural world: the unceasing circular motion of the sun (depicted as a weary runner), wind and rivers. The labour of the human observer of these phenomena is also suggested in this passage: "the eye is not satisfied with seeing nor the ear full of hearing" (1:8), i.e. that just as these items are in perpetual motion, so this results in a continual stream of information to our senses.12 At the same time, however, every one of these natural phenomena follows a predetermined path: the implication for Qohelet's view of human labour is clear. Humankind also follows a predetermined path, an idea which is implicit in the cycle of death and birth for humanity as a whole in 1:3.13 The idea of toil driven by dissatisfaction is also evident in 4:4, "Again, I considered

\footnotetext{
10 Jastrow (A Gentle Cynic, $214 \mathrm{n} .62)$ perhaps goes too far in seeing an autobiographical touch in 4:8, but Qohelet has in a sense experienced the disappointments of wealth in 2:11.

11 M. Devine (Ecclesiastes, or the Confessions of an Adventurous Soul [London: Macmillan, 1916] 100 ) detects a note of "sympathy with the rich" here.

12 Fox, Qohelet and his Contradictions, 69.

13 Levine, "The Humor in Qohelet," 78-79. By way of contrast, Ogden ("The Interpretation of רור in Ecclesiastes 1.4," JSOT 34 [1986] 91-92), followed by Whybray ("Ecclesiastes 1.5-7 and the Wonders of Nature," JSOT 41 [1988] 105-7) argues that refers to the cycles of the natural phenomena in $1: 4-8$.
} 
all travail, and every right work, that for this a man is envied of his neighbour"-Qohelet's comment here recognises the importance of rivalry and competition in human society but also contains the implication that competition leads to a vicious circle in which the individual drives himself without knowing the reason why, or without having an adequate reason for so doing. 14 As we shall see presently, a successful outcome to one's labour and the ability to make use of the material benefits therefrom is entirely dependent on the goodwill of the deity.

\section{God's Role in the Allocation of Joy}

Qohelet appears to recognize that it is necessary for human beings to achieve some kind of balance if they are to have any hope of contentment. Thus, he avers, "better is one hand full with quietness than two hands full with toil and chasing the wind" (4:8), and in a similar vein he comments, "better is the sight of the eyes than the wandering of desire" (6:9). 15 How is such an equilibrium to be achieved? This question is closely linked with the double-sided nature of God's gifts to humankind: on the one hand, God gives joy-the ability to "experience the benefits in one's labour", and on the other, toil-a sentence of hard labour without mitigating benefits. In order to illustrate this, the relevant parts of the seven passages which Whybray considers as central to understanding Qohelet's view of human joy will be considered in this section.

\section{$\underline{2: 24-26}$}

The text of this passage reads:

There is nothing better for a man than that he should eat and drink, and that he

\footnotetext{
14 Rudman, "A Contextual Reading of Ecclesiastes 4:13-16," 58.

15 Gordis also points out Qohelet's expression of the limited nature of joy here, i.e. that it lacks any "absolute value" in the grand scheme of things (Koheleth:The Man and His World, 261-62).
} 
should let himself enjoy the good in his labour. This also I saw, that it was from the hand of God...For God gives to the one who pleases him wisdom, and knowledge and joy: but to the one who displeases him he gives toil, to gather and to heap up, in order that he may give to the one who pleases God.

Qohelet generally finds it difficult to reconcile pleasure to wisdom, preferring to associate it with folly or madness $(2: 2,3 ; 7: 1-6)$. By contrast, wisdom is frequently associated with distress $(1: 18 ; 2: 23 ; 7: 1-6)$. Uniquely in the book of Ecclesiastes, pleasure is paralleled with wisdom in $2: 26$. In this context, it is significant that both lie within the "gift of God." Only God, it seems, can find a way of resolving the essential incompatibility between these two concepts and allow them to be present in a single individual. 16

The fact that it is God, and God alone, who grants both wisdom and joy to the individual points of itself to a deterministic agenda on Qohelet's part. Yet, Qohelet's explanation in 2:26 of how God acts to bring this state of affairs about is more significant still: God gives to the "sinner", that is to one who displeases him, ענין ("toil"). It is the fate of this unfortunate individual "to gather and to heap up" material wealth, to give to "one who pleases God." God thus determines the course of one's life whether one is favoured or not: everyone it would seem is subject to some degree of divine interference. 17

On another level, the fact of ענין being within God's gift means that divine interference in human actions is not momentary but continuous. In $1: 13$, the

\footnotetext{
16 In this context, it is worthy of note that Loader (Polar Structures in the Book of Qohelet, 38, 4142) argues that one should read ומי יחוש חוץ ממנו 2:25, partially supported by some manuscripts, the Peshitta and Coptic version (cf. Barton, Ecclesiastes, 97; Zimmerli, Der Prediger, 164; Hertzberg, Der Prediger, 81) He goes on to translate 2:25 "for who can eat and who can think without him?" There is a strong contextual case for this reading, which would certainly be a supreme exposition of determinism on Qohelet's part. Whitley (Koheleth: His Language and Thought, 28-29) is sympathetic to this reading but rightly cautious in the light of the fact that the secondary meaning "to worry/consider" for שוש occurs only in later Rabbinic Hebrew and Mandaic.

17 Cf. Fox's remark (Qohelet and his Contradictions, 188) that the complaint implicit in 2:26 has its basis in "God's all-determining will."
} 
expression "all things which are done under heaven" is described as the ענין רע which God has given (נתן) to humankind in general. In 3:10, the term ענין is used in conjunction with the concept of "God's gift" to humankind with reference to list of divinely appointed actions in 3:2-8.18 God's responsibility for all human action is, as we have seen in Chapter 3 of this thesis, reflected in Qohelet's parallel usage of "the work of God" with "the work which is done under the sun."

Returning once more to the theme of pleasure in this passage, Whybray's words are significant: "man should 'eat and drink and find enjoyment in his toil'; but this is possible only when it comes 'from the hand of God'. God may give joy and pleasure; man can never achieve it for himself, however hard he may try." 19 The

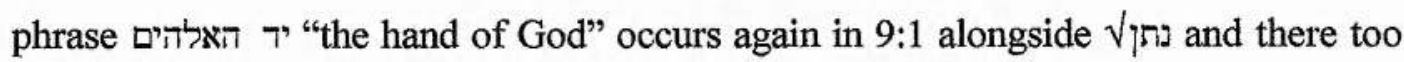
is indicative of Qohelet's deterministic worldview.

\section{$\underline{3: 1-12}$}

The depiction of joy or pleasure as "the gift of God" is in line with the predetermined nature of life evident in 3:1-8, in which Qohelet speaks of the times (ע) for all activities and feelings mapped out for humankind by the deity. Many commentators, as we have seen, continue to regard this as a deterministic text, and so it may appear odd that $\sqrt{ }$ שמח does not appear among the actions listed therein for which there is a divinely appointed time.

Whybray's thoughts on this passage are somewhat ambiguous. Despite his comment that "God may give joy and pleasure, man can never achieve it for

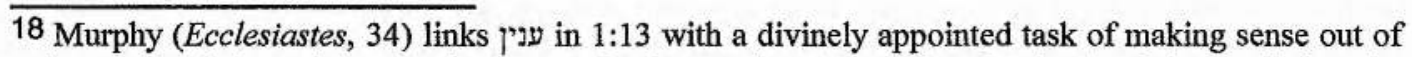
existence but is less clear as to its frame of reference in $3: 10$, stating simply that it is "applied to the problem of determinate times" in 3:1-8. It cannot mean that human beings are given the "toil" of making sense of these determinate times, since God acts in 3:11 to prevent human beings from "finding out" the work of God. Thus, the "toil" is that of carrying out these divinely determined actions. This occupies human beings to such an extent that they are unable to act under their own initiative to find out God's plan (3:11).

19 Whybray, "Qoheleth, Preacher of Joy", 89. Cf. Glasser, Le procès du bonheur par Qohelet, 53.
} 
himself,"20 the exegesis of this passage offered in his commentary follows the line that the "times" of 3:1-8 are ideal times, unknowable to human beings, for various actions. 21

Although pleasure may be to some extent predetermined by God is borne out by the appearance of $V_{p}$ in in the list of times in this passage, for Qohelet states that there is "a time to weep, a time to laugh" (3:4). Moreover, the title with which Qohelet prefaces his list of actions states that "to everything there is a season, and an appointed time to every matter under heaven." The universality of this passage is stressed by most commentators. 22

The text of 3:12-13 itself reads:

\begin{abstract}
I know that there is no good in them, except to rejoice and to fare well during one's life, and also that everyone should eat and drink and experience good in all one's toil: it is a gift of God.
\end{abstract}

In the face of the fact of divine control over humanity's actions asserted in 3:1-11, Qohelet's conclusion is as one might expect, "I know that there is no good for humankind except to rejoice (אין טוב [באדם] כי אם לשמוח)...it is the gift of God (מתח אלהים)" (3:12-13). In Chapter 3, I suggested that the "good" refers to the fact that it is an action over which the individual has some form of control, a suggestion borne out to some extent by the fact that enjoyment of life depends on being granted "authorisation" (שלטון) from God to do so. Even this "authorisation" is distributed according to "time", however (8:9). Paradoxically, this means that even for those

\footnotetext{
20 Whybray, Ibid., 88.

21 Whybray, Ecclesiastes, 66.

22 e.g. Delitzsch, Ecclesiastes, 254-55. Barton (Ecclesiastes, 98) also makes a link with Chapter 1 in this context and suggests the idea not only of all human action being carried out but all action also being repeated periodically.
} 
things which are apparently within our power we are dependent upon God. It is therefore the opportunity for pleasure which is determined by God rather than the feeling itself (or perhaps one could say that the feeling is determined indirectly, by means of the authorisation): in any case, this idea that humanity's ability to find joy is to some extent determined by the deity is expressed in $3: 13$ by the phrase "it is the gift of God."23

\section{$\underline{3: 22}$}

The next significant passage in which the same advice occurs is 3:22:

So I understood that there is nothing better than that a man should rejoice in his own works, for that is his portion (חלקו), for who shall bring him to see what shall be after him?

Qohelet's use of the term ("portion"), has already been a subject of study in Chapter 2 of this thesis. There it was concluded that one's "portion" in life was mainly associated with the realm of human emotions: joy $(2: 10 ; 3: 22 ; 5: 17$ [Eng. 18]), love (9:9) or love, hate and envy (9:6).24 This conception of "portion" was also notable, however, in that God was also depicted as the giver or allotter of one's portion in life $(5: 18)$. As Fox points out, the refusal to take one's portion can be construed as a refusal to submit to God's will (9:9).25 God's control over human emotions is another pointer towards Qohelet's deterministic view of existence.

In this context the term is once again indicative of God's role in the allocation of pleasure. Yet there is also another aspect to this verse: one's portion is

\footnotetext{
${ }^{23}$ Loader (Polar Structures in the Book of Qohelet, 105) notes however, "The conclusion drawn...is laden with tension because enjoyment comes from God. Enjoy, but remember that God's gift could just as well have been different (another $e t$ can come).

24 This aspect of the concept of portion is illustrated by Fox's helpful study (Qohelet and his Contradictions, 57-59, 258).

25 Ibid., 59.
} 
to "rejoice in one's own works." In 3:11, Qohelet remarks that God acts as he does in order that "no-one might find out the work of God", and in $8: 17$, he states that "noone can find out the work which is done under the sun." Implicit in Qohelet's words in 3:22 is the counsel that that human beings should rejoice individually in their own actions and leave those within God's sphere to God himself ("who shall bring him to see what shall be after him?").26

\section{$\underline{5: 17-6: 2}$}

Qohelet's commentary on the dissatisfaction experienced by the avaricious man considers the situation of the man whose wealth is lost in an unlucky venture $(5: 12-13)$. Material wealth, it seems, may be lost as quickly as it is gained. This emphasises the lack of control which human beings have over their destiny in much the same way as 9:11. By itself, this remark need not be suggestive of determinism, however.

There are, however, a number of other significant features in the subsection 5:17-19 which do betray a deterministic outlook on life. The text in question states:

Behold that which I have seen: it is good and comely for one to eat and drink, and to experience the benefits of all one's labour which one takes under the sun all the days of his life, which God has given (נת) him: for it is his portion (חלק). Every man also to whom God has given riches and wealth, and has given him authority to use it, and to take his portion, and to rejoice in his labour; this is the gift of God.

\footnotetext{
26 Podechard (L'Ecclésiaste, 317-19), Gordis (Koheleth: The Man and his World, 238), Loader (Polar Structures in the Book of Qohelet, 106) and Fox (Qohelet and his Contradictions, 199) argue that this phrase, repeated in 6:12, refers to the individual's future in his own lifetime. This is the position taken in this thesis, but whether it is understood as referring to this or to foreknowledge of one's personal circumstances after death (Delitzsch, Ecclesiastes, 272; Whybray, Ecclesiastes, 81), or of events on earth after one's death (Murphy, Ecclesiastes, 37) or both of the latter (Barton, Ecclesiastes, 110; Crenshaw, Ecclesiastes, 105), the implication is the same: human knowledge is restricted to one's actions in the present. Concerning the future in any capacity, there is only ignorance.
} 
The imperative to pleasure is based not only on the fact that the ability to enjoy pleasure in a specific instance is a gift of God $(2: 26)$, but also here because life itself is a gift. Qohelet has come a long way from his initial reaction on discovering the absence of true meaning to human existence. In 2:17, he "hates life." Here he accepts that it is a gift to be made the most of. More significantly still, however, the ability "to eat and to drink and to experience the benefit in one's labour" is termed the "portion" of the worker.

God's purpose in allocating pleasure seems apparent in 5:19 for, speaking of the individual whom God favours, Qohelet comments, "he shall not much remember the days of his life, for God occupies him by the joy of his heart (בשמחת לבו)." Like the process of labour, joy prevents humankind from dwelling on the futility of his existence. Joy, and indeed, woman occupy the intellectual/emotional side of one's character (ל) occupied just as labour does the physical side.27 The לב is the part of Qohelet which attempts to grasp the underlying nature of existence during the royal experiment (1:17), but the לב also "rejoices" in his labour or the products thereof (2:10). It is only when Qohelet turns and takes a second, closer look at his achievements that he sees their הבל, and begins to seek something more substantial.28 God's reason for allotting the gift of joy to certain individuals may not be disinterested.

Yet joy is not a universal gift. Qohelet also speaks of certain people who

27 Gordis argues against the idea that joy "deaden's man's sensibility to the brevity of life" (Koheleth: The Man and His World, 255-56) and derives ענה (I) "to answer" (cf. Jastrow [A Gentle Cynic, $219 \mathrm{n} .88$ ]), although this interpretation is behind the translations of the LXX, Peshitta and Vulgate. However, the basis for this, that "Koheleth regards joy not as a narcotic, but as a fulfillment of the will of God" fails to take into account the possibility that joy's narcotic quality may reflect God's will. Fox argues against Gordis's position effectively on linguistic grounds (Qohelet and his Contradictions, 218).

28 Whybray (Ecclesiastes, 55-56) argues that joy is "vanity" in the royal experiment because it is acheived independently by Qohelet without divine assistance (thus it is opposed to the "gift of God"). Yet Qohelet achieves both wisdom and knowledge and joy in the course of his investigations (cf. 2:26). Even when it is clearly part of the divine gift, as in 9:9, joy is still "vanity", for "all is vanity" $(1: 2 ; 12: 8)$. 
have every material advantage in life but who for one reason or another, find themselves unable to make use of these benefits. This is illustrated in the following text:

There is an evil which I have seen under the sun, and it is common among men: a man to whom God has given riches, wealth and honour, so that he wants nothing for himself of all that he desires, but God does not give him the authority to use it and a stranger eats of it: this is vanity and an evil sickness (6:1-2).

This passage clearly shows the importance of God not only in the allocation of the initial gift of material benefits to the individual, but also in the opportunity to enjoy it. It is God who is the giver of "riches, wealth and honour": the individual does not acquire them for himself.29 It is also God, however, who gives or withholds "authorisation" ( $\sqrt{\omega}$ של-5:18 [Eng. 19]; 6:2) to use the material goods which one acquires during one's toil. Seow has correctly pointed out the legalistic overtones of Qohelet's use of $\sqrt{ }$ טeש.30 God is portrayed by this means as an absolute ruler who controls every action of his subjects. His apparent arbitrariness in the choice of his favourites $(2: 26 ; 5: 17 ; 6: 2)$ only serves to make the parallel to the despotic rulers of Qohelet's time closer. 31

\section{$\underline{8: 15}$}

God's role in the allocation of joy is also implicit in 8:15 in which Qohelet states:

29 Crenshaw (Ecclesiastes, 125) remarks concerning this concept of divine gift, "This knowledge that life's pleasures cannot be earned through diligence and good conduct undercuts the fundamental premise of wisdom thinking...In Qohelet's affirmations about God, the notion of divine gift loses its comforting quality. The gift comes without rhyme and reason; it falls on individuals indiscriminately. Those who do not receive it can do nothing to change their condition." At the same time, though divine gifts may be unpredictable, Qohelet does not suggest that they are random.

30 Seow, "The Socioeconomic Context of 'The Preacher's' Hermeneutic," 176-181; "Linguistic Evidence and the Dating of Qohelet," 653-54.

31 This assessment holds true whether one dates Ecclesiastes to the Persian or Greek periods. 
So I praised joy, for a man has no better thing under the sun than to eat, and to drink, and to be merry: for that shall remain with him of his labour during his life, which God gives him under the sun.

Qohelet, as Whybray notes, goes further in this passage than in his previous commendations of joy by praising (שבח) it as a positive benefit. 32 His thought has developed somewhat since $4: 2$ in which the same verb occurs when he stated, "So I praised (שבח) the dead more than the living." The reasoning for taking this opportunity is not so much that God has given (נתן) life to humankind, but that he has given a relatively short span of life.33 This life, in Qohelet's view is to be made the most of, but the fact that pleasure is a second best option for all Qohelet's recommendation is illustrated by Qohelet's use of the formula אין טוב... "כי אם "there is no good...except." 34

Although God's role in the allocation of pleasure is not emphasised in this text as in others, the rationale behind finding enjoyment is suggestive of God's role as the one who gives and takes away life. By extension, this implies joy as part of the divine plan for human beings. This is particularly evident in the next passage to be considered.

\section{9:7-9}

The text of 9:7-9 is a crucial one for understanding how Qohelet's recommendation to joy fits in with his deterministic worldview:

\footnotetext{
32 Whybray, "Qoheleth, Preacher of Joy," 87.

$33 \mathrm{Cf}$. Whybray (Ecclesiastes, 102) on the relationship between the brevity of life and the possibility of joy: "Qoheleth does not disguise this limitation of man's enjoyment: it is precisely this limitation which adds point to the advice to enjoy life as much as possible."

34 Ogden ("Qoheleth's Use of the 'Nothing is Better' Form," JBL 98 [1979] 341-50) notes the function as a partial response to the generally negative answer required to the question מה יתרון לארם but also links it strongly to deterministic thought: the only good for the individual is to follow along the path that God has willed for him.
} 
Go, eat your bread with joy and drink your wine with a happy heart, for God has aiready approved your actions. Let your clothes be always white and let your bead lack no ointment. Experience life with the woman you love all the days of your vain life which he has given you under the sun, all the days of your vanity, for that is your portion in this life, and in your labour which you undertake under the sun.

The imperative to joy in 9:7-9 is a remarkably strong one. It is particularly significant for understanding God's role in the allocation of joy to the individual because Qohelet bases his advice on the fact that "God has already approved your works" (כבר רצה האלהים את מעמיך). The precise meaning of this phrase is a matter of some debate among commentators. The verb רצה "to accept" used in this verse is elsewhere used of the pleasure which God takes in sacrifices (Deut 33:11; Amos 5:22 etc.). The idea for Murphy is therefore that this divine pleasure means "the mysterious approval and gifts freely bestowed by God" (cf. 2:26). Presumably, this would mean, as with Whybray, that the fact that God has given human beings the opportunity to take pleasure in life means that God has in general approved the taking of pleasure. 35

This, however, is not what the texts says. The statement that "God has already approved your works" would appear to suggest that the choices which the individual makes and the resulting actions are known in advance by God (how else could one's actions be "already approved"?). Qohelet's use of the more general term "your works" (את מעשיך) as opposed to a more specific reference such as "these works", "pleasure" or the like, which one should perhaps expect, is suggestive that he understands such actions as simply one part of the overall activity which God has

35 Murphy, Ecclesiastes, 92; Whybray, Ecclesiastes, 144. So also Barton, Ecclesiastes, 162; Fox, Qohelet and his Contradictions, 259. 
willed for humanity. 36

In the wider context, such a reading is in line with the deterministic worldview advanced by Qohelet in Chapter 9 as a whole. Thus, Qohelet states in 9:1: "the righteous and the wise and their works are in God's power [lit: "the hand of God"]: no-one knows either love or hatred by all which is before them." God's sphere of deterministic control is delineated here as "the righteous and the wise and their works (מעטשיהם)", thus prefiguring the statement that "God has already approved "your works" (מעשיך) in 9:7.37 Notably, the phrase "the hand of God" (יד האלהים) recurs in 9:1 in this heavily deterministic passage: elsewhere, it is used in the context of God's gift of joy to those he favours $(2: 24) .38$

The same deterministic atmosphere is evident in 9:11-12. The divine nets and snares of 9:12 and their relevance for determinism have already been discussed in Chapter 5.39 This is reinforced by the occurrence of the phrase עת ופגע (time and event") in 9:10 as the controlling factor in the outcome of human endeavour. As has been argued in Chapter 2, this passage is similarly indicative of Qohelet's deterministic outlook on existence.

In the context of these passages, the statement in 9:7 that "God has already approved your works" is an affirmation of the necessity of deriving pleasure from life in the light of Qohelet's deterministic view of the same. The rationale given for

\footnotetext{
מעש in the specific (but still deterministic) sense: "Qoh. estime que si le travail d'un homme lui a procuré quelques facilités de jouir, c'est une marque certaine que Dieu veut qu'il jouisse en effet, car Dieu seul donne les biens et le pouvoir d'en profiter..."

37 Delitzsch (Ecclesiastes, 354-55) interprets 9:1 in this overtly deterministic way extending even the emotions of human love and hatred to God's control (cf. Rudman, "Woman as Divine Agent in Ecclesiastes," 421). The fact that it is the wise whose actions are under God's control links neatly with 9:7 for Qohelet advises the wise disciple, whose actions are thus divinely "approved." The same position is also held by Galling (Der Prediger, 113) and Loader (Polar Structures in the Book of Qohelet, 102).

38 Ogden ("Qoheleth IX 1-6," VT 32 [1982] 160) notes the appearance of the phrase in 2:24 but understands 9:1 in a non-deterministic sense. God determines the "outcome" of an action rather than the action itself.

39 Rudman, Ibid., 417-19.
} 
Qohelet's advice is that one may as well enjoy life to the full because God has already decided what we are to do. Qohelet's use of the "nothing is better" formula in the context of joy takes on a deeper significance therefore. For Qohelet's avowed aim is to find out "what was that good that men should do under the heavens." Since all is predetermined, such a search loses its raison d'être -and Qohelet can conclude that there is nothing better than to "sit back and enjoy the ride."

This reading of 9:7 is lent further support by the appearance of Woman in 9:9. Again, I have argued that Woman acts as a divine agent in Qohelet's worldview. The entrapment vocabulary with which she is associated in 7:26 make her a universal force from which escape is possible only through the assistance of God. This is reflected in 9:9 in which Qohelet advises his reader to "experience life with Woman whom you love." No choice is given over whether Woman is loved: this is taken for granted by Qohelet. 40

Thus, the passage 9:7-9 reflects the wider context of Chapter 9 in which it is placed but also establishes links with several other deterministic passages in Ecclesiastes. Once again, God's role in the allocation of human joy is amply illustrated by Qohelet.

\section{$\underline{11: 8-12: 7}$}

The next and final section in which joy is recommended, indeed commanded, by Qohelet is found in 11:8-12:7. For the purposes of making detailed comment, 11:8-10 are reproduced below:

But if a man live many years and rejoice in them all, yet let him remember the days of darkness, for they shall be many. All that comes is vanity. Rejoice, young man, in your youth and walk in the ways of your heart and in the sight of your

40 Ibid., 421. 
eyes but know that for all these things God will bring you into judgement. So remove sorrow from your heart, and put away evil from your flesh, for childhood and youth are vanity.

Part of the rationale for the enjoyment of life is the consciousness of the finality of death. but Qohelet also makes a rather strange statement: that God will "bring into judgement" the young man, holding him accontable for the actions which Qohelet recommends. Yet recommend them Qohelet clearly does, both before and after this warning of divine judgment. What can be meant by this sentence "Know that for all these God will bring you into judgement"?

This phrase therefore requires discussion. In Chapter 2, it was argued that the term משפט is expressive of one aspect of God's determination of all events. Yet this particular passage depicts God judging human beings for following Qohelet's advice concerning the enjoyment of life. Life itself and the ability to enjoy life are clearly stated elsewhere to be the gift of God $(2: 26 ; 5: 18$ [Eng. 18]; 8:15;9:9;12:7). Can the idea of God's judgement in this passage be reconciled with Qohelet's advice to make use of this opportunity here and elsewhere?

Gordis attempted to resolve the difficulties posed by the appearance of this sentence in such a context by arguing that God will judge the youth according to the way in which he has used the opportunities for joy granted to him. ${ }^{41}$ Others have pointed out that the idea of divine judgement is not a concept alien to Qohelet, and therefore that even if such a judgement implies a negative attitude towards human pleasure on the part of the deity it is compatible with Qohelet's thought.42 More

\footnotetext{
41 Gordis, Koheleth: the Man and His World, 336.

42 The case for retaining 11:9b is propounded by Wildeboer, Der Prediger, 161; Gordis, Koheleth: the Man and his World, 336; Jones, Proverbs and Ecclesiastes, 341; Ogden, "Qoheleth IX 7-XII 8: Qoheleth's Summons to Enjoyment and Reflection," VT 34 (1984) 31-32; Fox, Qohelet and his Contradictions, 279; Fredericks, "Life's Storms and Structural Unity in Qoheleth 11.1-12.8" 101; Murphy, Ecclesiastes, 117.
} 
typically, however, the statement is seen as a gloss. 43

The structure of the passage 11:9-12:8 as a whole is as follows: ${ }^{44}$

$11: 8$

$12: 1$

$12: 2$

12:6

$12: 8$
If a man lives many years

let him rejoice

and remember

the days of darkness will be many

all that comes is hebel

Rejoice

(in your youth)...in the days of your youth

for youth...is hebel

Remember

in the days of your youth

before...

before...

before...
Time Phrase

Theme A

Theme B

Time Phrase

Conclusion

Theme A

Time Phrase

Conclusion

Theme B

Time Phrase

Conclusion

The same applies to the first stanza of this passage (11:9-10). If the sentence in question, ודע כי על כל אלה יביאיך האלהים במשפט"Know that for all these, God will bring you into judgement", is deleted from 11:9b, the structure of this short passage can clearly be seen:

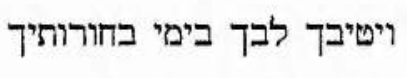

ובמראי

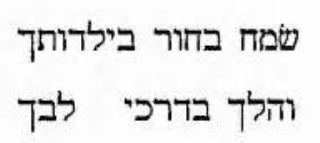

43 Siegfried, Prediger und Hoheslied , 73, followed by McNeile, An Introduction to Ecclesiastes, 26; Barton, Ecclesiastes, 185; Podechard, L'Ecclésiaste, 452; Jastrow, A Gentle Cynic, 238; Zimmerli, Das Buch des Predigers Salomo, 242; Scott, Proverbs \& Ecclesiastes, 254; Galling, Prediger Salomo, 120; Salters, The Book of Ecclesiastes: Studies in the Versions and the History of Exegesis, 227; Crenshaw, Ecclesiastes, 184.

44 This scheme is derived from Ogden (Qoheleth [Sheffield: JSOT, 1987] 193-94), based upon the study of H. Witzenrath (Süss ist das Licht...: Eine literaturwissenschaftliche Untersuchung $z u$ Kohelet 11:7-12:7 [MUSKTF. ATSAT 11; St. Ottilien: Eos, 1979). 
"A Time to Laugh": Qohelet and Human Joy

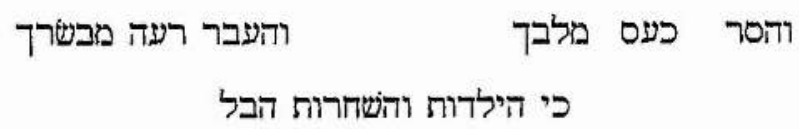

Rejoice, young man in your youth

Walk in the ways of your heart

Remove sorrow from your heart
Let your heart cheer you in the days of your youth

And in the sight of your eyes

Put away evil from your flesh

For youth and dark hairs are vanity

The first line introduces the overall theme of enjoying youth; the term ילדות in the first half is balanced by בחורות in the second half, whilst the succession of imperatives dominate the passage as a whole (שמח "rejoice", "טיב" "let cheer" (jussive), "walk", הסר "remove", העבר "put away"). Of itself, this would not point to 11:9b being a gloss, for it too uses an imperative, דע "know." Significantly, however, it appears between the second and third lines of this passage which appear to form a couplet. Line $2 \mathrm{a}$ and $3 \mathrm{a}$ give advice with respect to the intellectual/psychological side of the young man's life "your heart": these are, however, balanced by the physical dimension to life in $2 \mathrm{~b}$ and $3 \mathrm{~b}$ as expressed by the terms "your eyes"/"your flesh." That there is a close relationship in structure and thought between the second and third lines of the passage above is clearly suggested by its structure, yet the phrase is interposed between them in the MT, breaking up both the rhythm and the thought of the passage.

This consideration alone might give grounds for suspicion that Qohelet himself was not responsible for 11:9b. Yet commentators deny the authenticity of this phrase on other grounds: the similarity between על כל אלה יביאך האלהים במשפט in 11:9b and a corresponding expression, את כל מעשה האלהים יבא במשפט על כל נעלם in 12:14 is striking, and has led many to suppose that the addition of 11:9b has resulted from the influence of the second epiloguist. That is, an attempt has been 
made to interpret the extended passage 11:7-12:7 in the light of the pious comment of the second epiloguist in 12:14. This may also underly the MT's reading of "your creator."45

Whilst it is true that Qohelet speaks of judgement elsewhere in Ecclesiastes, it is the context of this particular occurrence that gives cause for suspicion. In 3:17, Qohelet mentions that God will judge the righteous and wicked as a natural follow up to his observations about the lack of human justice. The fact that this remark is made in the context of there being "a time there for every purpose and every work", recalling his original statement in 3:1 gives it a ring of authenticity. The fact that it is God who is the subject of the verb reinforces the idea that these times refer to the appointed times for divine activity, or to human activities which are determined by God.

Likewise, the terms עת משת משט speaks of the sage's ability to detect God's activity in the events which occur on earth and also humanity's distressing situation resulting from the divine control of such events. Again, there is a clear echo of $3: 1,17$ in the phraseology of 8:6: "because to every business there is time and judgement, therefore the misery of man is great" (כי לכל חפיץ יש עת ומשפט כי רעת האדם רבה עליו).46 This use of the term משפט finds no parallel in 11:9. On the basis of this, and the other evidence adduced, it should therefore be considered as a gloss.

This consideration of the passage 11:8-12:8 has so far sought to demonstrate that God does not seek to judge those who make use of the material benefits they

\footnotetext{
45 I emend to בורך "your grave", with Scott (Proverbs Ecclesiastes, 253). This best fits the context as delineated by the overall structure of 11:8-12:8. 12:1 should be a recapitulation of Theme B, i.e. a reminder of the brevity of life (cf. 11:8). It is possible to retain the MT's בוראי "your Creator" if this is understood as an oblique reference to God's role in giving and taking away life (Fox, Qohelet and His Contradictions, 300; Murphy, Ecclesiastes, 117).

46 Fox, Qohelet and His Contradictions, 247.
} 
derive from life. The receipt of and ability to use these benefits are part of the gift of God and to that extent are determined by God. Nevertheless, the emphasis in this passage is on human rather than divine activity as the succession of imperatives in 11:9-12:1 suggests. This does not detract from Qohelet's essentially deterministic worldview, for as I have argued in Chapter 5 of this thesis, the ability to act for oneself depends on God's authorisation (של itself subject to "time."

\section{Conclusion}

Although a certain amount of human free will is presupposed in the taking of pleasure, indicated by the legalistic use of $\sqrt{ }$ (t) to suggest God's acquiescence in such actions, and by the imperative forms which Qohelet uses in his exhortations to the reader to enjoy life (cf. esp. 9:7-10; 11:9-10), the fact remains that human beings according to Qohelet's worldview are entirely dependent on God for the finding of pleasure. 47

First of all, humanity is reliant on God for the material goods from which pleasure may be derived (2:26; 5:18 [Eng. 19]; 6:2). Qohelet speaks of pleasure in terms of eating and drinking $(2: 24 ; 3: 13 ; 5: 17$ [Eng. 18]; 8:15; 9:7). It is also closely associated with material wealth (2:1-11; 5:17-19 [Eng. 18-20]; 10:19). Only God can provide these things: human efforts to acquire them are doomed to failure. Secondly, and more significantly, human beings are dependent on God for the ability to make use of the material wealth which they acquire (5:18 [Eng. 19]; 6:2). This is a fundamentally new idea in the Hebrew Bible. For whereas God is shown to bestow riches on the sage in Proverbs, the implications of God being responsible for the ability of the individual to make a choice as to whether such wealth is used points

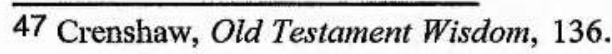


more strongly to a deterministic outlook on life.

It is perhaps too fine a distinction to make as to whether God "gives" joy per $s e(2: 26)$, thereby imposing it on human beings, or whether he is responsible simply for giving the ability to find joy in life (5:18 [Eng. 19]). Qohelet seems to have viewed the two as identical. What is certain, however, is that the acquiescence of the deity is absolutely essential to human attempts to find happiness. In this area, as in others, God's control over human life is absolute. 


\section{Chapter 8 \\ Determinism in Early Jewish Literature}

\section{Introduction}

How does Qohelet's conception of determinism relate to his Hebraic background? The determinism in the catalogue of times and seasons does, as has been pointed out, have general parallels in the Hebrew Bible. Thus, the Psalmist states concerning his relationship with God in 31:15, "My times are in your power" (עתחי בידך) in the sense that God is able to determine what happens to the Psalmist and to rescue him from his enemies if he so desires. 1 Such a position, however, is not far removed from the traditional view of God in the Hebrew Bible who intervenes in history to rescue or punish Israel, the community, or the individual. Such activity, though it may be called "Providential" is certainly far from deterministic. 2

Before continuing further, it would be as well to redefine the criteria by which one may properly call a particular view of the world deterministic. Determinism is the belief that some outside force (usually God) controls the thoughts and actions of the individual and thereby intervenes in one's life not merely on a regular basis, but constantly. This intervention must be true of all individuals, so that God can be said to control the workings of the world down to its smallest details. A limited amount of free will may be presupposed (particularly in the moral/ethical sphere) but generally the room for humanity having control over their own impulses may be said to be severely restricted.

However, it is clear that "deterministic" is a term which is applied to Ecclesiastes by some commentators in a very loose sense. For example, Blenkinsopp argues that Qohelet is a determinist, yet is reluctant to see the catalogue of seasons as

\footnotetext{
1 Fox, Qohelet and his Contradictions, 195; Murphy, Ecclesiastes, 33.

2 Whybray (Ecclesiastes, 66) points out Qohelet's negative view of human freedom as contrary to conventional wisdom. This, in fact is also true of the Hebrew Bible generally,
} 
asserting this idea because of the extent to which this would subordinate human free will to that of the deity. For him, as indeed for Whybray, Qohelet's determinism means that events are "predisposed" to happen rather than preordained. 3 Most recently, this view has also been echoed by de Jong, who when he states that "God acts deterministically" in Ecclesiastes, means by this statement that the deity acts "according to non-moral standards."4

The rationale for de Jong's article is to demonstrate that the God of Qohelet is "...the same as the God of Abraham, Isaac and Jacob", and by defining the concept of determinism so loosely (that is, by saying that it refers to God's action outside the narrow bounds of reward-retribution imposed by the sages), he naturally finds many parallels within the Hebrew Bible (Prov 16:1, 4, 9, 33; 18:22; 20:24; 21:1, 31; Job $1: 21 ; 2: 10 ; 3: 23 ; 9: 17-20,22-24,28-31 ; 10: 3,15 ; 12: 4,6,16-25 ; 16: 7-17 ; 19: 6 ; 21: 7-$ $9 ; 23: 13-17 ; 24: 1,12 ; 27: 2 ; 30: 20-23 ; 33: 9-11) .5$ Relatively few of these passages can be said to be deterministic in the truest sense of the word (Prov 16:1, 4; 20:24), with God controlling the thoughts and actions of the individual: most simply contain the idea of God's inscrutability, or of God controlling the outcome of one's actions, or the events which happen in one's life. This is not, strictly speaking, determinism, but God acting in a way which is similar to an impersonal Fate. While this idea is evident in Ecclesiastes, it is important to distinguish between God as "Fate", and God as a deterministic force in existence.

An example of something approaching determinism in the Hebrew Bible may be found in Exod 7:2-3, where God states to Moses: "You shall speak everything which I command you and Aaron your brother shall speak to Pharaoh, that he shall

3 Whybray, Ibid., 66; Blenkinsopp, "Ecclesiastes 3.1-15: Another Interpretation," 61-63.

4 De Jong, "God in the Book of Qohelet: A Reappraisal of Qohelet's Place in Old Testament Theology," 156.

5 De Jong, Ibid., 154, 166. 
send the Israelites out of his land. Then I will harden Pharaoh's heart and multiply my signs and wonders in the land of Egypt." Thus God is shown to control Pharaoh's thoughts and actions in this particular instance in order to fulfil a wider plan. However, this idea seems more designed to provide an explanation for Pharaoh's continuing (and successful) resistance to the God of Israel in the narrative rather than genuinely to express a deterministic worldview (cf. Gen 20:6). In 2 Samuel 24:1-10, we find a story in which God incites David to sin by making a census and then punishes Israel for this act. ${ }^{6}$ An example of near-determinism may be seen in the story behind Ahab's decision to fight at Ramoth-Gilead in $1 \mathrm{Kgs}$ 22:20-23 in which Yahweh allows a "lying spirit" to speak through Ahab's prophets in order that the king should go to his death. This however, is a rather indirect form of determinism (indeed Ahab's free will is presupposed in the necessity for Yahweh to go to such lengths to ensure his death). Other texts in the Hebrew Bible can be said to have a quasi-deterministic element to them. For example, in Ps 139:16, the Psalmist states: "Your eyes saw my limbs unformed in the womb, and in thy book they are all recorded; day by day they were fashioned, not one of them was late in growing (NEB Translation)." A rather more overt example may be found in the call narrative of Jeremiah (Jer 1:4-10).

In many ways, however, these texts seem to be the exceptions that prove the indeterministic rule. Generally speaking, the Hebrew Bible cannot be said to advance a concerted idea of determinism. The indeterminacy of events is captured in particular by Von Rad when he cites Jer 18:7-10:7

Sometimes I threaten a nation or a kingdom, to uproot it and demolish it and destroy it; but if the nation which I threaten turns from its wickedness, then I shall

\footnotetext{
6 Cited along with Exod 11:10 by A. A. Di Lella, "Wisdom of Ben Sira," in $A B D 6.942$.

7 Von Rad, Wisdom in Israel, 270.
} 
repent of the evil which I have decreed for it. Sometimes I promise a nation or a kingdom, to build it and plant it; but if it does something that displeases me and does not heed my words, then I repent of the good which I had promised to it.

This is the very opposite of determinism, for here it is God's activity which is determined by the deeds of humanity and not vice versa. Nothing is preordained. No decision of God is irrevocable. Everything depends on the decisions which free human beings make in the present. This position is echoed in numerous texts in the Hebrew Bible (e.g. Judg 2:11-19; 2 Chr 34:11-13; Jon 3:10-4:2).

Despite the general indeterminacy of the Hebrew Bible, it is possible to say that there may be links between Ecclesiastes and its biblical background as regards the concept of a deterministic God. More likely, however, is a connection with the literature of the Hellenistic period, which shows a more overt interest in the idea of determinism than the older biblical texts. ${ }^{8}$ As shall be demonstrated presently, some of these later writings contain close parallels of language and thought to the work of Qohelet.

\section{Text and Context}

\section{(a) The Book of Daniel}

A few similarities between the thought of Qohelet and that of the author of the book of Daniel have already been mentioned in the course of this thesis. The authors of Daniel and Ecclesiastes both use $\sqrt{ }$ in its technical legal sense which is characteristic of earlier periods. However, the usage in both texts is differentiated from that of say, the authors of Ezra-Nehemiah, by the metaphorical sense in which the root is employed: God in these later texts, is seen as the supreme holder of pib

\footnotetext{
8 Von Rad (Wisdom in Israel, 264) also picks up on the sudden increase of the usage of the term in both Ecclesiastes and Ben Sira. Deterministic texts cited by Von Rad include Ben Sira (c. 180 B.C.E.), Daniel (c. $250-160$ B.C.E.), Judith ( late second Cent. B.C.E.).
} 
and dispenses it at will to his favoured human subjects. ${ }^{9}$ On the other, Eccl 4:13-16 appears to make use of the court story genre in much the same way as the author of Daniel.10 This need not mean that Qohelet was actually familiar with the book of Daniel. It would, however, appear to suggest that there is a common background to both.

The idea of an "appointed time" in its deterministic sense also appears in the book of Daniel. Thus in 2:21, Daniel praises God, saying "He changes times and seasons (ודוא מהשגא עדניא וזמניא), deposes kings and sets up kings."11 This is an idea broadly similar to the thought of Qohelet: indeed, the terms used in this verse, זמן and עדן, are direct Aramaic parallels to the terms עת ממן which Qohelet uses together in $3: 1$.

The idea of determinism underlies apocalyptic literature, as we shall see presently, and thus it should come as no surprise to find similar uses of the term עדן in the sense of a time appointed by God in the later portions of the book of Daniel. Thus, in 7:12 Daniel states that subsequent to the stripping of power from three of the four beasts which appear in 7:4-7, "their lives were prolonged until a season and a time (עד זמן ועדן)." At the appropriate preordained moment in history, it is promised that God will utterly crush the enemies of the saints. Likewise, the fourth beast is permitted by God in Dan 7:22 to have dominion over the earth "until the ancient of days came...and the appointed season came that the saints possessed the kingdom (וזמנא מטה מלכותא החסעו קדישין)."

Thus, there are similarities between the author of Daniel's conception of "time" and that of Qohelet. The most striking is in the use of the parallel terms עדן or זמן for a divinely appointed time which is indicative of a deterministic worldview. In

\footnotetext{
9 Rudman, "A Note on the Dating of Ecclesiastes."

10 Rudman, "A Contextual Reading of Ecclesiastes 4:13-16," 61-63, 65-69, 72.

11 Von Rad, Wisdom in Israel, 268.
} 
this respect, Qohelet would appear to be indebted for the idea of determinism to his Hebraic background. However, it should be noted that the determinism of Daniel (and indeed of Apocalyptic literature as a whole) is largely a global phenomenon. God determines the rise and fall of kings and empires, but relatively little interest is shown in smaller events applicable to the life of the individual such as we find in Ecclesiastes.

\section{(b) Apocalyptic Literature}

As has been suggested already, the concept of determinism is most often associated with Apocalyptic literature, and it is for this reason that Von Rad suggests that the roots of such literature lie ultimately in Wisdom (of the Mantic variety), rather than in Prophetic Eschatology. 12 This position has been followed to some extent by H.-P. Müller, M. E. Stone, J. J. Collins, K. J. A. Larkin and M. A. Knibb but remains controversial. 13

God's foreknowledge of earthly events, which provides the very basis for apocalyptic literature, is asserted in number of texts. 14 Thus, in As. Mos. 12:4; 1 Enoch 39:11, one reads that God has foreseen everything that will happen in the world. Several Qumran texts also express this idea (1QS 3-4; CD 2:3-10; 1 QH 1:7-8, 23-25; 4 Q180 1; 1QpHab 7).15 Implicit in this idea of divine foreknowledge of

\footnotetext{
12 Ibid., 277.

13 H.-P. Müller, Mantische Weisheit und Apokalyptik (VTSup 22; Leiden: Brill, 1972) 271-80; M. E. Stone, "Lists of Revealed Things in the Apocalyptic Literature," in Magnalia Dei: The Mighty Acts of God, ed. F. M. Cross et al. (Garden City: Doubleday, 1976) 414-52; J. J. Collins, "Cosmos and Salvation: Jewish Wisdom and Apocalyptic in the Hellenistic Age," HR 17 (1977) 121-42; K. J. A. Larkin, The Eschatology of Second Zechariah: A Study in the Formation of a Mantological Wisdom Anthology (Kampen: Kok Pharos, 1996) 248-53; M. A. Knibb, "You are indeed Wiser than Daniel': Reflections on the Character of the Book of Daniel," in A. S. van der Woude (ed.), The Book of Daniel in the Light of New Findings (BETL 106; Leuven: Leuven University/Peeters, 1993) 399.. 411.

${ }^{14}$ A. Yarbro Collins (ed.) (Early Christian Apocalypticism [Semeia 36; Decatur: Scholars, 1986) 7) defines apocalyptic as "a revelation...mediated by an otherworldly being to a human recipient...intended to interpret present earthly circumstances in the light of the supernatural world and of the future."

15 G. W. E. Nickelsburg, "Eschatology (Early Jewish)," in $A B D 2.585$.
} 
earthly events is that of determinism, since these events must be fixed in order to be foreseen. From this must arise the question of what is the predetermining factor at work in human history. Von Rad argues, on the basis of 1 Enoch 85-90, that this is God himself.16

In the book of Jubilees, God shows to Moses all of past and present history $(1: 4)$, which is recorded on tablets stretching from the moment of creation to the day of the new creation (1:29). Even relatively small details in the lives of the patriarchs are preordained: the giving of the name Isaac (16:3) and Isaac's curse on the Philistines (24:33). Likewise, Isaac's son Jacob read from the heavenly tablets of destiny "what would happen to him and his sons for all eternity" (32:21). Such ideas are, however, not confined to apocalyptic literature. The same theme of Yahweh determining the history of Israel may be found in Judith's prayer: "You designed the things that are now and are yet to be, and what you intended happened. The things you have ordained present themselves and say, 'Here we are.' For all your ways are prepared and your judgement has already taken place" (Jdt 9:5-6).17 In this context, it is interesting to note the idea of God's determination of events as a form of judgement (cf. Eccl 8:5, 6), and of this judgement having taken place prior to the occurrence of the action that is being judged. One may compare Eccl 9:7, "Go, eat your food with pleasure and drink your wine with a cheerful heart, for God has already approved your works" for a similar thought (albeit aimed at the individual rather than the nation).

The determination of events in history is typically demonstrated in Apocalyptic thought with reference to the nation or the community rather than the

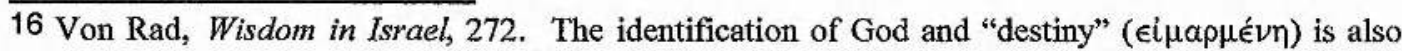
made several times by Josephus (J.W. 4.297; 6.250, 268, cf. 288-315)-so H. W. Attridge, "Josephus and his Works," in M. E. Stone (ed.), Jewish Writings of the Second Temple Period (Assen: Van Gorcum; Philadelphia: Fortress, 1984) 205.

17 Ibid., 270-72. God's determination of historical events is also explicitly stated in 4 Ezra 6:1-6; 13:58. 
individual, although the implications for the latter are clear and are sometimes alluded to. However, no real attention is given to the problem of how human free will fits into this deterministic scheme. D. S. Russell remarks on this situation and states "The clash of human freedom and divine control had not as yet become a conscious problem, so that these two apparently contradictory points of view could be expressed side by side without any intellectual difficulty. For the most part, the point of view of the apocalyptic writers is that of 'normative' Judaism as expressed in Rabbi Akiba's celebrated statement: 'all is foreseen, but freedom of choice is given' (Pirqe 'Abot 3.16)."18

Thus, in 1 Enoch 30:15, the idea that human beings are free to make moral choices concerning good and evil is stressed, despite the fact that elsewhere in the same book it is stated that one's future actions are written down before one is created (1 Enoch 53:2). Likewise, it is stated in Apoc. Abr. 26 that God is free to do as he sees fit, but that humanity also have free will. Nevertheless, this statement is juxtaposed with a scene in which God shows Abraham what will befall his descendants in the future (Apoc. Abr. 27). In 2 Apoc. Bar. 48:40; 85:7, human free will in the moral sphere is also given emphasis. 19 The fundamental illogic of this position is outlined by J. J. Collins, who remarks concerning the clash between determinism and free will in the book of Jubilees that "If "the judgment of all is ordained and written in the heavenly tablets in righteousness,' this is especially a warning for 'all who depart from the path' that 'if they walk not therein, judgment is written down for every creature and for every kind' $(5: 13) .{ }^{20}$

Thus, in general, early Jewish writings would appear to mask the problem of

18 D. S. Russell, The Method and Message of Jewish Apocalyptic (OTL; London: SCM, 1964) 232. 19 Ibid. . Cf. also G. H. Box, The Apocalypse of Abraham (London: SPCK; New York: Macmillan, 1918) 74-75.

20 J. J. Collins, The Apocalyptic Imagination (New York: Crossroad, 1984) 66. 
determinism and its ethical implications for human beings by emphasising divine foreknowledge over determinism (although, as I have mentioned, the one cannot exist without the other). Such an approach is fundamentally different to that of Qohelet, who mentions divine foreknowledge only in 9:7. Elsewhere in Ecclesiastes as we have seen, God's activity as the determining force in existence is constantly asserted and human freedom severely restricted.

\section{(c) Ben Sira}

In Chapter 1 of this thesis, Sirach's deterministic thought was mentioned briefly with reference to its possible relationship either to Stoic philosophy or a biblical background. It is at this point that a some consideration of the nature of the determinism in Ben Sira is appropriate. First of all, it is noticeable that Sirach concerns himself explicitly with the ethical dilemmas which the theory of determinism raises. Logically, blame for human wrongdoing in a truly deterministic scheme lies with the deity, but this is an aspect of deterministic thought which is for the most part passed over in the Jewish authors mentioned thus far. However, it is this problem which is considered in Sir 15:11-20:

Do not say, "The Lord is to blame for my failure"; it is for you to avoid doing what he hates.

Do not say, "It was he who led me astray"; he has no use for sinful men.

The Lord hates every kind of vice; you cannot love it and still fear him.

When he made man in the beginning, he left him free to take his own decisions;

if you choose, you can keep the commandments; whether or not you keep faith is yours to decide.

He has set before you fire and water; reach out and take which you choose;

before men lie life and death, and whichever he prefers is his.

For in his great and mighty power the Lord sees everything.

He keeps watch over those who fear him; no human act escapes his notice. 
But he has commanded no man to be wicked, nor has he given licence to commit

$\sin$.

(NEB Translation)

In Chapter 5 of this thesis, it has been argued that Qohelet makes a concerted attempt to find an explanation for the presence of human wickedness in the light of his deterministic worldview. The way this is done is by advancing the idea that God in some circumstances gives an individual "authorisation" (שלטמן) to act as he will. Indeed in 8:9, Qohelet states that there is "a time (ע) in which a man has authorisation (שלט) over another to harm him." This could be interpreted as saying that God not only allows wickedness but actually commands it in some circumstances. This, as I have argued leads logically on to the thought of Driver's suggested emendation of 8:10, "and so I saw the wicked approaching and entering the holy place, walk about and boast in the city that they had done right."

It is this point of view which is explicitly attacked by Sirach when he states that "he has commanded no man to be wicked, nor has he given licence to commit sin (לא צוה אגוש לחטא ולא החלים אושי כזב)." Although Sirach does not utilise context, the same viewpoint provides the basis for both passages. The wicked men whom Qohelet describes in Eccl 8:10, who "walk about in the city and boast that they had done right" are addressed by Sirach when he says "Do not say, 'the Lord is to blame for my failure'...Do not say, 'it was he who led me astray." Under the circumstances, it may be that a moral crisis was provoked by the general acceptance of deterministic thought in the third-to-second centuries B.C.E. as its ethical implications became apparent, and that both Qohelet and Sirach bear witness to a growing awareness of this problem in certain circles.

Despite his condemnation of those who would argue against the existence of 
free will in the moral/ethical sphere, Sirach (like other Jewish authors) does in fact assert divine foreknowledge of earthly events. Thus in 23:20 he states, "Before it happens, everything is known to him, and similarly he sees it before it is finished" (טרם נברא הכל גודע לו וכן אחרי כלות הכל יראה).21 Yet divine foreknowledge of an event need not necessarily imply the presence of God as the motivating force behind it. Thus far, Sirach's view can be argued to be consistent with his rejection of theological determinism in the moral/ethical sphere.

Like the Apocalyptic writers, Sirach is torn between the wish to present God as the prime mover in earthly events, but also to exonerate God from possible blame for human wickedness. Thus ethical freedom, as well as being explicitly stated, is also implicit in texts such as Sir $4: 26 ; 7: 1-3,8,12-13 ; 8: 5 ; 21: 1-2 ; 23: 18-20 ; 27: 8.22$ At the same time, a limited form of determinism is also asserted in 33:7-15:

Why is one day better than the others, while all the daylight of the year is from the sun?

They were separated by the wisdom of the Lord, and he made the times and feasts different.

Some of them he made exalted and holy, and some he counted as ordinary days.

Men are all made of clay, and Adam was created from the earth.

In the fullness of his wisdom the Lord separated them and made their destinies different.

Some he blessed and exalted, and some he made holy and brought near to himself.

Some he cursed and humbled, and hurled from their place.

Like the potter's clay in his hands, to form it as he pleases,

So are men in the hands of their Creator to give to them as he decides.

As good is the opposite of wicked and life is the opposite of death, so the sinner is the opposite of the godly.

So look upon all the works of the Most High; they are in pairs, the one the

21 The Hebrew of this passage is ambiguous. Here I have followed the translation offered in Von Rad (Wisdom in Israel, 265). The NEB translates, "Before the Universe was created, it was known to him, and so it is since its completion." However, this still expresses the idea of divine foreknowledge of the actions of the sinner in 23:18.

22 Di Lella, "Wisdom of Ben Sira," 942. 
opposite of the other. ${ }^{23}$

Several themes found in Ecclesiastes appear in this passage. God's determination of individual days finds some echo in Eccl 7:14. Sirach considers the inscrutability of God's gifts to humanity (cf. Eccl 2:26; 5:18 [Eng. 19]; 6:2). No causal connection is suggested between human righteousness or sin and God's blessings and curses. God's reasons for acting as he does are shown to be inexplicable.

In Chapters 2 and 3 of this thesis, it was argued that the catalogue of seasons was effectively a list of divinely determined human activities. In this context, one may point to Sirach's comment "Look upon all the works of the Most High; they are in pairs, the one the opposite of the other" (cf. Eccl 3:1-8). Even Sirach's exhortation to "look upon all the works of the Most High" finds its parallel in Qohelet's exhortation "Look upon the work of God" (7:14), and his claim that "I saw all the work of God" (8:17).

However, it is doubtful whether Sirach is in actual fact asserting full determinism in this passage: what is envisioned here is a world in which God may "give to (the individual) as he decides", rather than controlling his thoughts and actions. In other words, God controls what happens to the individual rather than what that individual says and does. God is shown to be an inscrutable distributor of favours but he is not a puppet master.

In the light of this conflict between theological determinism and free will, of which both Qohelet and Sirach are aware, it is notable that the ways in which these two authors approach the problem differ markedly. Qohelet is forced to recognise, at least partially, the truth of the wicked man's claim that the responsibility for human misdeeds lies with God. Sirach protects God from such a charge by arguing that 
human beings are entirely free to make their own ethical decisions. The determinism of Sirach is therefore broadly similar to that of the Apocalyptists and unlike that of Qohelet.

\section{(d) Psalms of Solomon}

Certain of the themes which we find in Ben Sira concerning divine determination of events and human free will are also apparent in the Psalms of Solomon, which probably date from the first century B.C.E. 24 In 9:4, for example, the Psalmist states "Our works are in the choosing and power of our souls, to do right and wrong in the works of our hands." 25 This clearly demonstrates an awareness of the ethical dilemmas presented by deterministic beliefs since the Psalmist's emphatic avowal of free will implicitly argues against the suggestion that God may be responsible for human iniquity: such a statement would not be necessary if there were no doubt that human beings retained control over their own thoughts and actions.

Yet the Psalmist does not reject the idea of determinism outright, for he states in 14:5 that God "knows the secrets of the heart before they happen", meaning at the very least that God is able to foresee whether a given individual will turn out good or bad, but possibly implying that God has more specific foreknowledge of the thoughts and actions of the individual. Likewise, in 5:6 the Psalmist states that the portion of the individual in life is predetermined by God and is unchangeable. 26

Again, it is important to remember that an assertion of God's foreknowledge of an event is not the same as saying that God himself has determined it. Hence the

24 J. L. Trafton, "Solomon, Psalms of," in $A B D 6.115$.

25 Verse numbers and translations from the Psalms of Solomon are from J. H. Charlesworth (ed.), The Old Testament Pseudepigrapha Vol. 2 (London: Darton, Longman \& Todd, 1985).

26 The tension between divine determination and human free will in these passages is noted by Russell (The Method and Message of Jewish Apocalyptic, 232-33). 
Psalmist, as we have seen, can state that God knows the motivations of the individual and how they will be acted upon (14:5), without being himself the cause of that motivation (9:4). Because of this foreknowledge, God can prejudge the individual and predetermine the individual's portion in life (5:6). The theology of the Psalms of Solomon is therefore, in its essentials, in line with the statement of Akiba that "all is foreseen, but freedom of choice is given."

\section{Conclusions}

Qohelet's conception of determinism clearly owes a great deal to his Hebraic background. Yet, while there exist deterministic echoes in the Hebrew Bible, these are relatively few. In general, the Hebrew Bible may be said to be indeterministic in the sense that although God regularly intervenes in history, human beings remain in control of their own moral choices and, generally speaking, over their own actions. It is only in the Hellenistic period that we find anything like an idea of determinism consistently being advanced in the apocalyptic literature of that time. 27

One way in which this debt to his Hebraic background is evident in his choice of the terms עמן to express the idea of divinely appointed times for events which impinge upon human existence. Both terms appear in this context in the book of Daniel, a product of the Hellenistic period. Even more striking are the parallels which can be made with extrabiblical texts. Determinism is at the heart of Jewish apocalypticism, and though this concept is typically expressed through global events, reference is sometimes made to its implications for the individual.

There are, however, differences between Qohelet's approach to the consequences of determinism and that of the apocalyptic writers. Broadly speaking, the apocalyptic writers attempted to claim complete sovereignty for God over

27 Russell (Divine Disclosure [London: SCM, 1992] 14) sees apocalyptic as essentially a product of the Hellenistic period, from 250 B.C.E. on. 
earthly events, so that everything was said to be predetermined.28 However, the same writers also wished to retain the idea that human beings were free to make moral/ethical choices since the alternative, that God was responsible for the actions of the wicked, would have denied the goodness and justice of God and indeed would have rendered the law invalid. 29

Thus a tension is clearly apparent in apocalyptic thought: one may find juxtaposed visions of a future which is preordained with an assertion of human free will. Clearly such writers were aware of the conflict between determinism and free will and a partial solution is offered by emphasising divine foreknowledge rather than divine determinism per se (although foreknowledge implies determinism). Yet, even where determinism is emphasised, it is typically the determination of events rather than human action which is depicted. The same approach to this problem is also evident in the Psalms of Solomon and Ben Sira. Faced by the conflict between determinism and free will, both assert the orthodox idea that human beings are entirely free moral beings, but also make claims of divine foreknowledge elsewhere.

The form of determinism advanced by Qohelet therefore differs significantly from that of his fellows. Faced with moral evil in humanity, Qohelet does not entirely absolve the deity of blame. Although God is removed from the implication of direct responsibility for wickedness, he is still accused of giving the wicked the freedom to commit evil. Moreover, a question mark hangs over even the morally upright as to whether they can take credit for their own actions, for in 9:1, Qohelet states that "the righteous, and the wise, and their works, are in God's power..." The wicked are conspicuously absent from this observation, so that a situation appears to exist in which the deterministic God can take the credit for the actions of the good,

28 L. Morris, Apocalyptic (London: Inter-Varsity, 1973) 47-48.

29 Russell (Divine Disclosure, 113-14) makes the connection between the apocalyptists' assertion of free will and of the consequent necessity of obedience to the law. 
while he is distanced at least to some extent from the evil. As we shall see presently, this position has a parallel in Stoic thought. 


\section{Chapter 9 \\ Qohelet and Stoic Determinism}

\section{Introduction: A Note on Methodology}

As was suggested in Chapter 1 of this thesis, the idea that the book of Ecclesiastes was subject to Stoic influence is not a new one. Indeed, this position was widely held in some scholarly circles at the end of the last century. 1 Since then, the emphasis in more recent years has been on understanding Qohelet solely in the context of his Hebraic background, 2 and although some commentators have detected a certain Hellenistic colouring to his work, this has been attributed to the influence of a general Zeitgeist rather than to direct contact with Greek philosophy. ${ }^{3}$

Nevertheless, the idea that the author of Ecclesiastes was influenced by specific ideas from Greek philosophy is still advanced by a small but significant minority of scholars. 4 Recent years have also seen several new attempts to claim links between Ecclesiastes and Stoic thought. 5 To this extent, a comparison between Qohelet's deterministic worldview as I have attempted to reconstruct it in this thesis and that of the early Stoics, who similarly held that all earthly events were preordained by God, is a worthwhile exercise; the more so since Qohelet's approach to the subject of determinism has been shown in the previous chapter to differ in

\footnotetext{
1 Tyler, Ecclesiastes, 10-29;Plumptre, Ecclesiastes, 30-32; Condamin, "Notes sur l'Ecclésiaste."; Siegfried, Der Prediger, 8-10.

2 Earlier commentators who held that Qohelet was not subject to Greek influence include Renan (L'Ecclésiaste,62-63) ; McNeile (An Introduction to Ecclesiastes, 43-44), Barton (Ecclesiastes, 34). More recently their ranks have been joined by Loretz (Qohelet und der Alte Orient, 134), Seow (Ecclesiastes, 16).

3 Hengel, Judaism and Hellenism, 1.115-30, 126-27; Fox, Qohelet and His Contradictions, 16; Murphy, Ecclesiastes, xliv-xlv.

4 Recent exceptions include Braun (Kohelet und die frühhelenistische Popularphilosophie, 167-71); Lohfink (Kohelet, 7-15 esp. 9).

5 Gammie, "Stoicism and Anti-Stoicism in Qoheleth," 169-187; Blenkinsopp, "Ecclesiastes 3.1-15: Another Interpretation," 55-64; Levine, "The Humor of Qohelet," 78. Kaiser ("Determination und Freiheit beim Kohelet/Prediger Salomo und in der Frühen Stoa," NZSTh 31 [1989] 251-270) makes no attempt to prove dependence, restricting himself largely to a comparison between the thoughtsystems of the author of Ecclesiastes and the first three Stoic leaders.
} 
some essentials from those of his Jewish contemporaries.

In considering the possibility of Stoic influence on Qohelet, it is important to restrict material for comparison to known Stoic beliefs of the third century B.C.E. It is therefore necessary, as far as possible, to distinguish between the ideas of different Stoic philosophers and common Stoic belief. 6 While it is true that our knowledge of early Stoicism is entirely dependent on reports and quotations found in other ancient writers such as Cicero (c. 106-43 B.C.E.) and Diogenes Laertius (fl. 200-220 C.E.), there remains evidence enough to reconstruct the worldviews of the first three leaders of the Stoic school, Zeno (fl. 300-261 B.C.E.), Cleanthes (fl. 261-232 B.C.E.) and Chrysippus (fl. 232-208/4 B.C.E.) whose dates straddle the period in which the current scholarly consensus would place the composition of Ecclesiastes.

\section{Determinism and Stoic Thought}

The philosophy known as Stoicism may be divided into three main branches: physics, logic and ethics. Much of Stoic thought was profoundly influenced by the work of Heraclitus (fl. 500 B.C.E.), who taught among other things that there was a universal logos or rationality which controlled the workings of the universe. ${ }^{7}$ Although only fragments of Heraclitus's work survive, making it impossible to say for certain whether he was a determinist, this concept is a logical corollary of his philosophy and was advanced enthusiastically by the Stoics.

There are, however, other precursors to the deterministic philosophy of the Stoics. The mechanistic atomist Democritus (b. $460-457$ B.C.E.) argued that all events occur in a predictable way through a series of atomic collisions: this comes close to the idea of determinism advanced by the Stoics, but Democritus appears not

6 Gammie, Ibid., 173. This necessity is also emphasised by J. B. Gould (The Philosophy of Chrysippus (Leiden: Brill, 1970) 1-6.

7 W. K. C. Guthrie, History of Greek Philosophy (Cambridge: C.U.P., 1972) 1.428; M. C. Nahm. Selections from Greek Philosophy (New York: Appleton-Century-Crofts, 1968) 62. 
to have considered the implications of his philosophy for human free will. 8 Another proponent of an idea close to determinism was the Pre-Aristotelian philosopher Diodorus Cronus, one of the school referred to by Aristotle as the Megarians. The philosophy of determinism is not fully developed in Diodorus's thought, but he does attempt to advance a logical (albeit flawed) argument for its existence. 9

\section{(a) Chrysippus (fl. 232-208/4 B.C.E.)}

It was the Stoics who first propounded a far-reaching and elaborate form of determinism.10 In particular, this idea is generally attributed to Chrysippus, the third leader of the Stoic school and indeed those commentators who have argued for Stoic influence on the thought of the author of Ecclesiastes have typically suggested a link with Chrysippus. 11

This position is not without its problems, however. The most significant of these is that Chrysippus's leadership of the Stoic school began in 232 B.C.E. Commentators have generally been reluctant to date Qohelet's work much after 225 B.C.E., since the social conditions which are presupposed therein suggest that Qohelet lived in a time of peace and prosperity (at least as far as the upper classes were concerned). 12 The invasion of Palestine by Antiochus III in 219-17 B.C.E. saw the country change briefly from Ptolemaic to Seleucid hands bringing to an end over a hundred years of peaceful economic development under the Ptolemies. Although Antiochus was forced to withdraw after the Battle of Raphia in 217 B.C.E., Ptolemaic rule during the closing years of the third century B.C.E. was marked by

\footnotetext{
8 J. B. Gould, "The Stoic Conception of Fate," JHI 35 (1974) 19.

9 Taylor, "Determinism," in P. Edwards (ed.), The Encyclopedia of Philosophy (New York: Macmillan, 1972) 2.360.

10 J. Den Boeft, Calcidius on Fate: His Doctrine and Sources (Brill: Leiden, 1970) 2.

11 Gammie, "Stoicism and Anti-Stoicism in Qohelet," 184; Blenkinsopp, "Ecclesiastes 3.1-15: Another Interpretation," 58, 62.

12 Crenshaw, Ecclesiastes, 50.
} 
poor administration and internal dissension. Palestine fell into Seleucid hands, this time permanently, after the Battle of Paneion in 200 B.C.E. 13

Assuming, therefore, the dating of Ecclesiastes to $250-225$ B.C.E. to be correct, this would leave a period of only seven years for Chrysippus's distinctive teachings as leader of the Stoa to be formulated and to reach Palestine. However, Chrysippus had taken on the role of Stoicism's chief apologist much earlier. Gould states: "Cleanthes did not possess a combative nature, and even while he was nominally heading the Stoa, Chrysippus, his student, was the prime defender of the Porch against the assaults of the Epicureans...and those of the academics."14 So effective were these attacks on Stoicism that by the mid-third century B.C.E., Stoicism as a philosophy was in serious danger of being discredited. That it not only survived but even flourished thereafter may be attributed to the work of Chrysippus in countering objections from rival schools (SVF 2.6).15 Under the circumstances then, Chrysippean ideas may well have influenced the direction of Stoic thought at a relatively early stage. This idea is certainly reflected in a saying attributed to Chrysippus who remarked to his teacher Cleanthes that all he wanted was to be told what the main Stoic theories were, and he himself would find the proofs for them (SVF 2.1).

The question of to what extent Chrysippus's thought differed from that of his predecessors is a moot one. In general, it would be fair to say that his deterministic philosophy can be distinguished from that of his predecessors by its comprehensiveness, but also by its complexity; a result of attempting to find room

\footnotetext{
13 Hengel, Judaism and Hellenism, 1.7-9.

14 Gould, The Philosophy of Chrysippus (Leiden: Brill, 1970) 35.

15 Ibid., 9.
} 
for human free will in the moral sphere. This is in fact alluded to by Plutarch:16

\begin{abstract}
Anyone who says that Chrysippus did not make fate the complete cause of these things (right and wrong actions),...will reveal him as once again in conflict with himself, where he extravagantly praises Homer for saying of Zeus 'Therefore accept whatever evil or good that he may send to each of you',...and himself writes many things in agreement with this, and ends up saying that no state or process is to the slightest degree other than in accordance with the rationale of Zeus, which he says is identical to fate.
\end{abstract}

(Plutarch, De Stoic. Repugn. 1056b-c [SVF 2.997])

In a similar vein, Chrysippus is quoted by Gellius as saying that "Fate is a certain everlasting ordering of the whole: one set of things follows on and succeeds another, and the interconnexion is inviolable" (Gellius 7.2.3 [SVF 2.1000]). Two things are emphasised by these quotations. Firstly, Chrysippus's view of fate is that it controls all events on earth, all human action and even human thought (SVF 2.913, 925, 997). To this extent, it may justly be said that Chrysippus's worldview is deterministic in the truest sense of the word. Secondly, human beings are powerless to resist the dictates of Chrysippus's deterministic fate: it is an utterly implacable force.

Naturally, there are some general similarities between the thought of Chrysippus concerning fate and that of Qohelet. I have argued in Chaptets 2 and 3 of this thesis that Qohelet's statement in 3:1 that "there is a time for everything, and an appointed time for every business under heaven" and the catalogue of times in 3:2-8 outline a deterministic worldview in which all human actions and emotions are controlled by the deity. This also appears to be the purport of other key passages within the book of Ecclesiastes, such as 7:14, 26-29; 8:5-6; 9:7, 11-12. Like Qohelet

$\overline{16}$ Translations of Stoic texts in this chapter are derived from A. A. Long \& D. N. Sedley (The Hellenistic Philosophers [Cambridge: C.U.P., 1987] Vol. 1). The texts in their original languages may be found in Vol. 2 of the same work. 
who expresses the concept of determinism by equating "the work of God" with "the work which is done under the sun," Chrysippus sees fate as ultimately one and the same as the will of the deity (cf. Calcidius 204 [SVF 2.933]). ${ }^{17}$ Bearing in mind the evidence adduced in the last chapter about the nature of Jewish determinism, Qohelet's constant emphasis on the determination of human action and thought by God, rather than on God's foreknowledge, might in some ways appear closer to Stoicism than Jewish thought.

As has been suggested in Chapters 5 and 8 of this thesis, the espousal of a belief in determinism, particularly when the deterministic force is depicted as a benevolent God, results in a moral problem. How can life's injustices and the presence of human evil be explained? More importantly, does the presence of injustice and evil in life mean that God is the author of these things? With whom does responsibility lie for such actions: with the human doer, or with the deity who in theory controls all human actions? This problem is again discussed in the light of Chrysippean determinism by Gellius, who outlines a philosophical position against Chrysippus similar to that of Plutarch (i.e. in terms of the criminal who may appeal to deterministic philosophy to escape justice, cf. De Stoic. Repugn. 1056b-c [above]):

If Chrysippus they (holders of rival views) say, thinks that all things are moved and governed by fate and that the causes of fate and their turns cannot be changed or surmounted, then the faults and misdeeds of men ought not to cause anger or to be referred to themselves and their wills, but to a certain imperious necessity, which stems from fate; and this is the mistress and arbiter of all things, by which everything which will happen must happen; and for this reason punishments of criminals have been established by the law unjustly, is men do not come to their evil deeds willingly, but are led to them through fate.

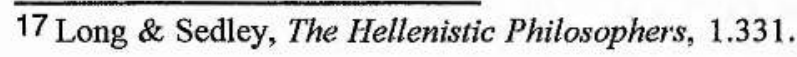


Such objections to Chrysippus's scheme of determinism must have surfaced early, for he is forced to make elaborate attempts to explain the presence of evil in a divinely determined world. For example, he suggests that the "good" things in life such as justice, truth or beauty derive their significance from the presence of their opposites in the world (Gellius 7.1.1-13 [= SVF 2.1169-70]). Evil may also be the necessary consequence of God's wider plan for good. Adversity may be a good thing in that it teaches the individual fortitude or other good qualities. Good may come from evil: an earthquake may rid the world of evil people as well as good. War may relieve overpopulation (Plutarch, De Stoic. Repugn. 1049a-d [= SVF 2.1125]).

Yet Chrysippus (like Qohelet and Sirach) explicitly considers the problem of the criminal denying responsibility for his crimes, and despite his deterministic beliefs argued that such people should be punished. 18

Thus, Gellius states on this subject:

(Chrysippus) denies that those who, whether through laziness or through wickedness, are harmful and reckless, should be tolerated and given a hearing, if when caught red-handed they take refuge in the necessity of fate, as if it were a temple-asylum, and say that their worst misdeeds are attributable to fate, and not to their own recklessness.

(Gellius 7.2.13 [SVF 2.1000])

An apocryphal story told about Zeno suggests a similar approach to the problem of moral responsibility for wrongdoing: "The story goes that Zeno was flogging a slave for stealing, 'I was fated to steal', said the slave. 'And to be flogged', was Zeno's reply." (DL 7.23). Another attempt to resolve the problem was to state

18 Gould (The Philosophy of Chrysippus, 149) suggests that Chrysippus "must have been somewhat bitter towards the wicked who thought that the Stoic doctrine of fate bestowed upon them the right to do evil deeds with impunity." 
that while determinism was a real force which controlled the cosmos, there were certain things over which human beings did have control ( $S V F$ 2.974), described as To

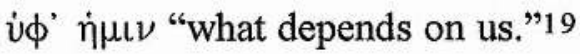

Examples of "what depends on us" focus on presentations in the mind which we may enact and make real or refrain from enacting. We do not have any control over how presentations enter out mind, so that for example, a man who has a picture in his mind of himself overeating, or of sleeping with a neighbour's wife, is not responsible for what he is thinking. It is, however, within his power to choose whether or not he enacts these things, and therefore human beings must bear responsibility for their own wickednesses ( $S V F$ 3.177). 20 Thus Chrysippus ends up asserting total determinism and moral free will side by side in much the same way as we have seen in some Jewish writings of this period. That is not to say that the position of these Jewish writers is influenced by Chrysippus: one can clearly see how they arrived at the same conclusions independently, but the parallel remains nevertheless.

At a superficial level, there are similarities between the thought of Qohelet and Chrysippus in their approach to the question of fate. Both authors lay an emphasis on determinism in their consideration of existence, and see God as the deterministic force behind earthly events. Both are conscious of the theological problem which this philosophy poses in considering human injustice and wickedness. Many other cultures, however, have expressed like concerns about the

19 Blenkinsopp ("Ecclesiastes 3.1-15: Another Interpretation," 62) in fact argues that it is this concept of free will that lies behind the series of actions enumerated in $3: 2-8$, as does Levine ("The Humor of Qohelet," 78) who sees the actions in this passage as denoting "human freedom in foolish opposition to determinism."

20 M. E. Reesor, The Nature of Man in Early Stoic Philosophy (London: Duckworth, 1989) 49-58. 
moral problems consequent from a belief in fate or determinism.21 Despite the similarities, it is also evident that Qohelet makes no such convoluted attempts as Chrysippus to explain human evil, nor does he demonstrate any knowledge of Chrysippus's position by attempting to argue against it. The position which Qohelet takes with the question of human evil in fact brings him somewhat closer in thought to Chrysippus's predecessor, the second leader of the Stoic school, Cleanthes.

\section{(b) Cleanthes (f1. 261-232 B.C.E.)}

Although Stoicism even from its inception laid great emphasis on the role of God in the workings of the world, it is Cleanthes who is generally credited with being the most religious of the Stoic leaders. 22 Cleanthes's pupil Chrysippus, as we have seen, is often asserted to be the first Stoic leader to advance the idea of an allembracing deterministic force which controls existence. Generally speaking, the viewpoint ascribed to his predecessors by some modern commentators is not dissimilar to traditional Greek conceptions of fate as a force which determines the major milestones in one's life, but in which the details remain under human control.23

Such a view is misleading, however. If it is clear that Zeno and Cleanthes were not fully determinist in their outlook, they nevertheless advanced viewpoints very close to it.24 Cleanthes in particular argued for the activity of Providence lying

\footnotetext{
21 B. C. Dietrich (Death, Fate and the Gods [London: Athlone, 1965] 3-5) cites the examples of a serpent in the Mahabharata (13.1) who devours a child and disclaims responsibility for the deed on the grounds that it was fated. Similar, in the Qur'an (35.8) is the assertion that "God leads astray whom he pleases and guides whom he pleases."

22 Gould, The Philosophy of Chrysippus, 34-35; Long \& Sedley, The Hellenistic Philosophers, 1. 332.

23 Long \& Sedley, Ibid., 1.342, 392.

24 Some classical scholars have indeed asserted that Chrysippus is totally beholden to his predecessors for his philosophy and made no original contribution to Stoic thought: in essence he recapitulated the ideas of Zeno and Cleanthes and systematized them (so A. C. Pearson, The Fragments of Zeno and Cleanthes [London: Clay, 1891] 48; E. V. Arnold, Roman Stoicism [New York: Humanities, 1958] 91). Not dissimilar (at least as far as the concept of determinism is concerned) is the view of Gould (The Philosophy of Chrysippus, 206), who argues that Chrysippus did not so much build his own deterministic world view as systematize that of his two predecessors.
} 
behind every walk of human life. This "Providence" was not a series of isolated acts of divine generosity but a continual and thoroughgoing intervention in the affairs of the individual and the world. Indeed, so extensive was God's interaction with existence that one may basically characterise Cleanthes's position by calling it a kind of "positive determinism." Such a view of life gives rise to the very same problem which Chrysippus faced later. How can this divine Providence be reconciled with wickedness? Cleanthes writes:

\footnotetext{
No deed is done on earth, God, without your offices, nor in the divine ethereal vault of heaven, nor at sea, save what bad men do in their folly. But you know how to make things crooked straight and to order things disorderly.
}

(Cleanthes, Hymn to Zeus, SVF 1.537)

As may be observed from this passage, the solution to the problem of human wickedness and how this can be reconciled with a belief in a benevolent deterministic God was a very simple one. Cleanthes assigned blame for humanity's wickedness with humanity itself and apportioned credit for human good deeds with the providential deity. Cleanthes speaks not just of major events being subject to external control but every human action not tainted by folly or wickedness.

If one considers the view of Providence offered by Cleanthes, it appears to be quite similar to that of Qohelet. I have argued in this thesis that the latter reconciles the concepts of free will and determinism by means of a parallel from the legal sphere. God gives שלטון "authorisation" to certain people to act as they wish (5:18; $6: 2 ; 8: 4,9 ; 10: 5)$. Qohelet recommends that this freedom be used to derive enjoyment from life (5:18) but others are also free to gain dominion over their fellows or to act wickedly (8:9). Others, perhaps well-meaning, make errors of judgement and upset the social order by giving preferential treatment to people of low rank at the expense 
of those who really ought to be honoured (10:5-6).

The implication of this is that while God in theory controls everything, He is not directly responsible for human injustice, folly or wickedness. Both Cleanthes and Qohelet stress the universality of God's intervention in existence, yet are careful not to assign blame for human wickedness directly to the deity. It is as if the wicked stand outside the control of the deterministic force, retaining freedom over their actions, while the good are enslaved by Fate, God, or whatever this power is called.

The same implication is made by Qohelet, who states "the righteous and the wise, and their works, are in God's power" (9:1). What Qohelet claims here is that God controls the thoughts and actions of "good" people.25 One might object that this verse could simply mean that the righteous and wise are dependent on the will of an inscrutable God for their "just" reward and that God alone can ensure that their actions have a successful outcome. 26 However, the position of 9:1 following 8:16-17 would appear to be significant. Qohelet has just linked "the work of God" with "the work which is done under the sun" and stated the impossibility of achieving his intention of "finding out" these things.27 No "wise man" can do so because, as 9:1 explains, "the righteous and the wise are in God's power."28

Nothing is said of the foolish or wicked-they are apparently not in God's power. The parallel between this thought and that of Cleanthes: "No deed is done on earth, God, without your offices...save what bad men do in their folly" is striking,

25 So Crenshaw, who states "The destiny of just people and wise is entirely at God's disposal, contrary to the sage's belief that they controlled their own destiny (sic). The term 'and their actions' refers either to what the wise and just think they accomplish in their own strength, or to their inability to do anything apart from the deity's prior approval" (Ecclesiastes, 159). Cf. Delitzsch, Ecclesiastes, 354-55; Hertzberg, Der Prediger, 153-55; Galling, Der Prediger, 112-13; Loader, Polar Structures in the Book of Qohelet, 101-2.

$26 \mathrm{McNeile,} \mathrm{An} \mathrm{Introduction} \mathrm{to} \mathrm{Ecclesiastes,} \mathrm{19;} \mathrm{Barton,} \mathrm{Ecclesiastes,} \mathrm{157-58;} \mathrm{Glasser,} \mathrm{Le} \mathrm{procès} \mathrm{du}$ bonheur par Qohelet, 140-41.

27 Rudman, "The Translation and Interpretation of Eccl 8:17a," 5.

28 Fox (Qohelet and His Contradictions, 257) also understands 9:1 in the light of 8:16-17, although his interpretation of the former is somewhat ambiguous. 
but it is, as I have suggested, borne out by the way that Qohelet uses $\sqrt{ }$ של to denote a degree of freedom from divine control in contexts having to do with human wickedness and injustice.

Yet while Qohelet is apparently sympathetic to the basic position adopted by Cleanthes, he also notes its weaknesses. The fact that human evil is a consequence of free will does not absolve the deity of all responsibility for the inequities of existence: it is God, after all, who gives freedom to people who will use it wickedly in the first place, enabling them to "boast that they had done right" (8:9). Moreover, God is often tardy in his judgement of such people: sometimes they may even go unpunished.

Qohelet's God therefore has a darker side than that of Cleanthes. While Cleanthes can say that the function of the Stoic god is "to make crooked things straight," Qohelet charges God with doing the exact opposite: "Consider the work of God-who can make straight what he has made crooked?" (7:13) and in a similar vein he says of existence in general, "The crooked cannot be made straight, nor the missing counted" (1:15).

Thus, there are similarities between the deterministic thought of Qohelet and ideas expressed by the early Stoic philosophers, notably Cleanthes: if this could be said to indicate some form of influence, it would support the generally accepted dating of Ecclesiastes to $250-225$ B.C.E., typically advanced on the basis of the social situation described by the book and its close correspondence with the situation in Palestine as depicted in the Zenon Papyri (c. $265-255$ B.C.E.). 29 On the basis of the evidence adduced so far however, one may well object that these similarities can only be considered as parallels (albeit striking ones), rather than the product of direct contact. This is a not unreasonable position. Although Murphy, commenting on 
criteria for demonstrating Hellenistic influences on the book of Ecclesiastes, is correct in warning against expecting evidence to be too specific and thus discounting more general connections as mere parallels, 30 more evidence (indeed, more specific evidence) is required before Stoic influence on Ecclesiastes should be given serious consideration.

Significantly, as the next section will demonstrate, Qohelet appears to show a more specific awareness of the concept of a controlling mechanism of the cosmos which the Stoic philosophers called the logos.

\section{Qohelet and the Logos}

(a) The Meaning of

Traditionally, commentators have interpreted the noun ("account") in one of two ways. On the one hand, there are those who have argued that Qohelet uses the term in a concrete way to refer to an account of existence which Qohelet hopes to piece together from his observations. On the other, it has also been suggested that the term nem has an abstract meaning, and that has an existence outside Qohelet's imagination.

Among those who hold to the first of these options is Fox, who suggests that "refers to both the process of reckoning and the solution reached." In other words, the term denotes the sum total of knowledge which Qohelet is able to establish as a result of his observations. ${ }^{31}$ Glasser follows the same line of thinking, seeing חכמה וחשבון as a hendiadys. For him, refers to "les estimations de la sagesse." and חכמה to the practical wisdom enabling Qohelet to see cause and effect

30 Murphy, Ecclesiastes, xliv.

31 Fox, Qohelet and His Contradictions, 241. 
in the world.32 The logical conclusion which follows from the arguments of both commentators is that the book of Ecclesiastes is itself the חשבון which Qohelet sought and which he has succeeded in finding.

This position is supported by the LXX which translates 9:10 with the Greek noun $\lambda \circ \gamma \iota \sigma \mu o ́ s$, derived from the verb $\lambda \circ \gamma i \zeta \in \sigma \theta a \mathrm{l}$ which has the sense of reckoning, evaluating, charging up a debt and typically denotes the act of (typically human) thought according to strict logical rules.33 In 7:25, ${ }^{33}$ is translated by $\psi \hat{\eta} \phi \circ 5$, which refers to a small stone (Hdt 3.12.1). Such stones were often used in counting (Hdt 2.36.4), and hence the term comes to have the alternative meanings "number" or "account" (P. Lips. 1.64.7; 1.105.17-19).34 The use of both terms emphasises the translator's belief that the term חשבון was used in the concrete sense of an "account" given by Qohelet of his investigations.

The second option, that the term refers to an abstract "account" or "sum" which is already in existence is upheld by Tyler, who argues for the meaning of "...plan, i.e. of the moral administration of the world. The idea represented by is, probably, the thought underlying and manifest in the condition of man viewed as the subject of a moral government."35 McNeile follows much the same path when he states that "Here, and in v. 27 it means 'the rationale of things', a law by which the perplexing phenomena of life can be explained." 36 Likewise, Whybray follows RSV "the sum of things" and remarks that Qohelet is seeking "something

\footnotetext{
32 Glasser, Le procès du bonheur par Qohelet, 124. Michel (Untersuchungen zur Eigenart des Buches Qohelet, 235-36) also argues for this understanding of the term the nature of the wisdom which Qohelet utilises.

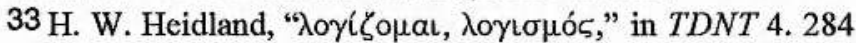

34 G. Braumann, "ঋn̂фos," in TDNT 9.904

35 Tyler, Ecclesiastes, 137.

$36 \mathrm{McNeile,} \mathrm{An} \mathrm{Introduction} \mathrm{to} \mathrm{Ecclesiastes,} \mathrm{75.} \mathrm{Similar} \mathrm{is} \mathrm{Podeschard} \mathrm{(L'Ecclésiaste,} \mathrm{385)} \mathrm{who}$ understands the
} 
which makes sense of the whole of 'That which is."'37

Both arguments have their adherents, and yet neither understanding of the term appears to be appropriate to every occurrence of the term in Ecclesiastes. In 7:25, for example, חשבמה is and indeed both Glasser and Whybray have suggested that the expression חכמה וחשבון is a hendiadys. The wisdom which Qohelet seeks, as Whybray well observes, is "not the superficial, conventional, 'practical' wisdom."38 It is termed "very deep" in 7:23 and Qohelet alludes to it in 7:24 as "far from me." In the sense that it is a wisdom designed to enable him to see the whole of that which is, it is something analogous to divine wisdom. Crenshaw describes it as "wisdom par excellence, as opposed to practical knowledge" which is one and the same as "the substance of human thought, the sum total of all knowledge." 39 Thus, there would appear to be good reason for thinking that the term in in in $7: 25$ refers to an abstract preexistent "account" or "sum of things" as Whybray terms it, which is coextensive with Wisdom. Whether it be seen as "wisdom par excellence" or "the reason of things", it is something more than the purely human-made account described by the LXX's $\psi \eta \hat{\phi} \circ \varsigma$ in this location. The finding of this חשבון (and 7:28 suggests that Qohelet failed in this regard) would give Qohelet a degree of mastery over existence. In the sense that it appears (as Crenshaw suggests) to denote the substance of human thought and (as Whybray suggests) to define "the whole of 'That which is", it would appear to be coextensive with "the work of God"/"the work which is done under the sun."

In a recent article, I have pointed out that the verbs בקט $(7: 25,28,29)$ and מצא (7:24, 26, 27 [twice], 28 [thrice], 29; 9:10) are constantly used in those passages

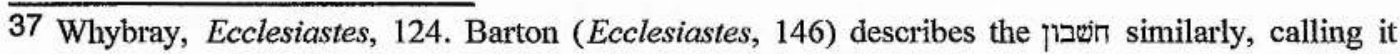
"the ultimate reality,"

38 Ibid, 124

39 Crenshaw, Ecclesiastes, 145. 
which speak of Tשבנות/חששבון. This suggests that Qohelet's me which he seeks is already in existence, there (in theory) to be found by those with the wisdom to find it: in other words it is an abstract concept (like "Wisdom"). The verbs and a במצא are also concentrated in 8:17 which, like 7:23-29, sums up Qohelet's investigation and in which Qohelet admits defeat: "Then I beheld all the work of God, that a man cannot find out (מצא) the work which is done under the sun, because though a man labour to seek it out (בקשט), yet he shall not find it (מצא); indeed, though a wise man think to know it, yet he shall not be able to find it (מצs)."

This verse, in which מצא בק occurs once, andee times with "the work of God", or "the work which is done under the sun" as their object, suggests that the term may be synonymous with "the work which is done under the sun", and/or "the work of God."40 The verbs מצא passages in which Qohelet speaks of the work of God, or the $13: 11 ; 7: 23-29$; $8: 17 ; 9: 10) .41$

חששבון therefore appears to connote the divine order, the מעמשה האלהים, thich should be apparent in "the work which is done under the sun" (מעשה ששעשה תחת) (השמש but, as the expression 7is 7:25 shows, it also denotes the wisdom by which that work is done or by which that work may be understood. Whybray's assertion that constitutes the whole of "That which is", as well as the suggestions that חשבון is the "rationale of things", or the "plan" for the "moral administration of the world" by McNeile and Tyler respectively appear to be borne out by the context in which מצא appear.

In 7:27, Qohelet clearly considers that he may come to know the "account"

40 Like Gordis (Koheleth: The Man and His World, 298-99), Fox (Qohelet and His Contradictions, 175) and Murphy (Ecclesiastes, 13), I argue that "the work of God" is one and the same as "the work which is done under the sun."

41 Rudman, "Woman as Divine Agent in Ecclesiastes, 423. 
by which God works by adding "one to one" from his observations. In doing so, he plays on the idea of a numerical account. This is a theme which runs throughout Ecclesiastes: Qohelet considers the "profit" (יותר מותר יתרון)-1:3;2:11, 15; 3:9, 19; $5: 15 ; 6: 8,11)$ and "loss" (1) "account" which governs the world. Interestingly, in 3:14, Qohelet uses similar language of the work of God, affirming that "what God does is eternal: there is no adding to it, and no taking away from it" (3:14).42 Again, if the חשבון is to be identified with "the work of God" (as I have suggested in Chapter 6), the "adding to" (גיט) and "taking away" (גרע) would refer to human attempts to interfere with the divine account which ensures that "That which is, is that which will be" (3:15). Thus, in the context of 7:27, could, and probably does have a double meaning, indicating the supreme account governing the world, and the account which Qohelet himself intends to form in the course of his calculations: one which will hopefully balance with the account par excellence. Rather than choosing between the opposing views of modern חששבון commentators, it may be as well to accept the idea that Qohelet uses the term in both its abstract and concrete senses.

It would appear that Qohelet plays on words again in 7:29, in which he remarks that "they (humankind) have sought out many nשכות." The MT points as

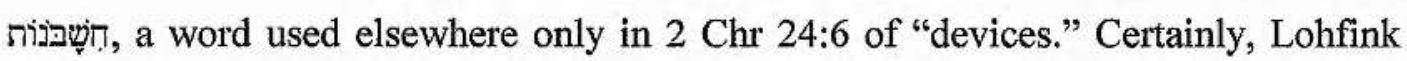
argues that the fact that Qohelet uses this word so soon after his uses of $7: 25,27$ suggests a double meaning. 43 Fox goes further, however, and sees the use of as indicative that 2 a merely the plural of that is mich is described in $7: 25,27.44$ For him, the context of this verse demands that a meaning such as

42 Staples ("Profit in Ecclesiastes," JNES 4 [1945] 88) also links the idea of the absence of "profit" to humanity's inability to act outside "the work of God."

43 Lohfink, Kohelet, 58-59.

44 Fox, Qohelet and His Contradictions, 243. 
"explanation, solution" be attached to חשבנות.

In Chapter 6, I have argued for the correctness of Fox's assertion, although I would not go as far as to claim that the whole of Ecclesiastes details "Qohelet's search for hišs To understand existence. The thrust of 7:29 may suggest a changeable abstract חשבון or possibly refer to the individual "accounts" which human beings have attempted to form of it. Qohelet's thought at this point is extremely obscure and no interpretation enjoys unqualified acceptance. On balance however, Fox's suggestion as to the meaning of חששבונות in this context would appear to make most sense.

Thus, in contrast to $7: 25,7$ in which apears to have a double meaning as a divine account governing the cosmos and an accurate human "account of the account" which Qohelet sets out to form, 7:29 appears to refer solely to human accounts of existence which have been sought. The context seems to militate against a divine "account" controlling existence, and this is reflected in the MT's pointing ("devices") and in the Vulgate's rendering, infinitis...quaestionibus ("many questionable things"). Nevertheless, the fact that Qohelet uses the singular $7: 25,7$ and 9:10 suggests strongly that the occurrence in 7:29 is merely the plural of חשבון as Fox indeed argues.

Eccl 9:10 is interesting in its usage of the term outside the immediate context of the passage 7:23-29 which has been under consideration:

Whatever your hand finds to do (מצא לעטות), do mightily (עשה בכז); for there is no work (מעטה), nor חשער) (חכמה) nor knowledge), nor wisdom Sheol, where you are going.

Here the term חשבון appears not to mean a divine account which governs 
existence (although Qohelet once again plays on words, for it is placed parallel to the חשבון מעשה משת and elsewhere contextual evidence would appear to suggest that the is coextensive with "the work which is done under the sun"). $\mathrm{N}$ or, however, does the term here seemingly refer to a human "account of the account." In its position parallel to attributes such as action (מעשחה), knowledge (דעת) and wisdom (חמה), the generality of which seems to be emphasised, it would appear to have a much more pedestrian sense than is found in $7: 25,27$ (although here as in 7:25, it is parallel to "wisdom" and "knowledge") and is therefore often translated "thought."45 This is a particularly strange usage of the term חשבון, and one which finds no echo elsewhere in Hebrew.

In summary, it is fair to say that Qohelet does not use the term any one meaning in all locations. In some locations $(7: 25,27)$ it refers to "the rationale of things" but also appears to be connected to "the work of God" or "the work which is done under the sun." Qohelet, however, indulges in a certain amount of wordplay in $7: 27$, however, so that it has a double meaning of the "account" which governs existence and the account which Qohelet hopes to make of it. In 7:29, the plural occurs of the false accounts made by others of existence, or perhaps suggests a changeable account. Finally, in 9:10, the term parallel to "Wisdom", "knowledge" and "Work/action" and is typically rendered by commentators in yet another way, as "thought." Thus, the term as Qohelet uses it has an extremely extended semantic range which apparently encompasses thought, wisdom, deed and calculation in both the human and divine spheres.

\section{(b) Stoicism and Qohelet: Two Accounts}

In his consideration of the possible links between Stoic philosophy and the

45 Crenshaw, Ecclesiastes, 158; 
thought of Qohelet, Gammie remarks that "Stoic philosophy is perhaps closest to Qoheleth in its affirmation of the operation of a universal logos, cosmic nature or God." 46 In Stoic thought, this logos was the rationality and structuring principle which governed the cosmos. It was therefore identified both with God and Fate.

Since the logos played such a central part in Stoicism, we should perhaps expect to find some trace of this idea in the book of Ecclesiastes if Qohelet's deterministic worldview owes anything to Stoic thought. A study of this term is therefore appropriate at this point.

\section{(i) The Meaning of the term Logos}

The Greek verb $\lambda \dot{\epsilon} \gamma \omega$, from which the noun $\lambda o ́ \gamma o s$ is derived, has two main senses: (1) To count, recount. (2) To say, speak. Although the derived verbal noun $\lambda$ ó ${ }^{\circ}$ ○s has a broad semantic range, its diverse meanings are connected to those of its parent verb: from (1) are derived the senses "computation, reckoning, (financial) account, measure, esteem." (2) provides the senses "explanation, argument, theory, law, saying." 47

The term logos became very much a key word in the thought of Heraclitus of Ephesus (c. 500 B.C.E.), who used it in the sense of a system or rationality which governed existence. This Heraclitean doctrine was taken up by the Stoics in the third century B.C.E.. This in turn provides a remarkable parallel with the thought of Qohelet. One aspect of the Heraclitean/Stoic concept of the Universe being based on a logos ("proportion, explanation, account"), is that it suggests an underlying mathematical basis for life and the events which occur in it.

46 Gammie, "Stoicism and Anti-Stoicism in Qoheleth," 180.

47 A. Debrunner (" $\lambda \epsilon ́ \gamma \omega$ A," in TDNT 4.73) notes this sense of "calculation" in Hdt 3.142, 143 and in the sense of "total" in IG IV, 1485, 145, 151, 154, 155, 161, 173, 178 and 1487,12, 18. Documents from Hellenistic Roman Egypt also, as he points out, use the term in the sense of a tinancial account or balance. 
As we have seen, Qohelet also shows a familiarity with and an interest in the concept of a universe definable by numbers. Significantly, the semantic parallel between the Heraclitean/Stoic logos and Qohelet's a in ilmost exact. Both have a mathematical sense of an account which may be added up, but both are also used in the sense of "explanation" to describe "the whole of that which is" by their different authors. Qohelet's חin as I have pointed out in a recent article, is described in terms which suggest that it is equivalent to "the work of God" or "the work which is done under the sun." 48 This, as we shall see, is also true of the Heraclitean/Stoic logos. In the words of Kleinknecht concerning this sense of the term: "It is presupposed as self-evident by the Greek that there is in things, in the world and its course, a primary $\lambda$ ó$_{0} 5$, an intelligible and recognisable law, which then makes possible

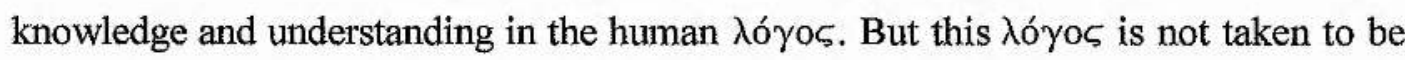
something which is merely grasped theoretically. It claims a man. It determines his true life and conduct." 49

\section{(ii) Logos in Greek Philosophy}

The concept of Logos is central to Greek thought. The pre-Socratic philosopher Heraclitus of Ephesus (c. 500 B.C.E.) was the first to use it as a focus for his worldview, however. The work of Heraclitus provides the basis for the philosophy of the Stoics, and through them exerts a powerful influence on later Jewish ideas about God's government of the cosmos.

Most of the time, Heraclitus uses the term logos in its more common meanings ("proportion, account, explanation"). However, he also used it in the sense of an underlying cosmic principle of order, an idea related to the more general meaning of measure, reckoning, or proportion with which the term may be

48 Rudman, "Woman as Divine Agent in Ecclesiastes," 423.

49 H. Kleinknecht, "خé $\gamma \omega \mathrm{B}$," in TDNT 4.81. 
invested. 50 Since all things occurred in accordance with this proportional arrangement, various phenomena which appeared on a superficial level to be disparate in nature could be said to be part of one cosmic order:

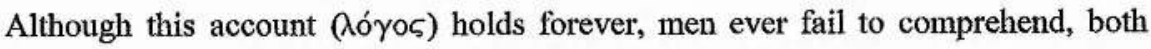
before hearing it, and once they have heard. Although all things come to pass in accordance with this account ( $\lambda$ ó $\% 5)$, men are like the untried when they try such words and works as I set forth.
\end{abstract}

(Sextus Empiricus, Adv. Math. 7.132 [=D.1])

Heraclitus is unique among the early Greek philosophers in seeing the logos as a rationality governing the universe, a cosmic principle controlling events on earth, and one, moreover which is established by God. In this, he is followed by the Stoics, who refer to logos as "the craftsman god...by which it is established both at which time each thing will come to birth and when it will perish" (Calcidius 293). The logos is evident as the wisdom governing the universe, but it is also the wisdom of humanity.51 Hence, Heraclitus can say: "Although the account (logos) is shared, most men live as though their thinking was a private possession" (Sextus Empiricus, Adv. Math. 8.133 [=D.2]). All human thought and action forms a part of the allpervasive logos which controls existence-as a result, Heraclitus can claim that human thought is "shared" rather than "private" to the individual.52

As I have already suggested, Qohelet's has the idea of an "account" or "rationale" which defines the nature of existence, but

\footnotetext{
50 Tobin, "Logos," 4.348.

51 Guthrie, (History of Greek Philosophy, 2.428), Nahm (Selections from Early Greek Philosophy, 67ff.) and G. S. Kirk (Heraclitus: the Cosmic Fragments [Cambridge: C.U.P., 1954] 39) translate

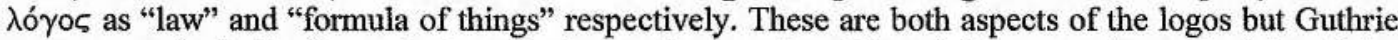
argues convincingly for a dual rendering as human thought and the governing principle of the universe.

52 Long \& Sedley (The Hellenistic Philosophers, 1.491) typically translate $\lambda o ́$ 'os by the term reason, rather than "account", although it can have both these and many other senses according to context.
} 
which also serves as its controlling mechanism $(7: 25,27)$. But Heraclitus also uses the term logos in the latter quotation in a dual sense. Primarily, it refers to the "account" which governs existence, but Heraclitus also plays on the idea of thinking which is inherent in the term. Thus, because the account is common, human thought is common. Qohelet also uses the term the with this play on meaning, for in 7:25, 27 it refers to the account which orders the world, Qohelet also plays on the background meaning of ("think", "consider") in 9:10 so that the noun there refers apparently to human thought.

This parallel usage is striking enough, but like Qohelet, who links the terms חכמה השכון in Eccl 7:25, Heraclitus also directly links the logos with wisdom: "It is wise, listening not to me but to the account to agree that all things are one" (Hippolytus, Refutatio 9.9.1 [ $=\mathrm{D}, 50]$ ). Again, this fragment emphasises that the logos has an independent existence of its own. Underlying the idea of the logos is the statement that 'all things are one': they are all a reflection of the action of a common logos, the system by which the events of life play themselves out. Wisdom lies in finding and listening to this logos, and agreeing with it.

The Stoic concept of logos, which goes on to play such an important part in Jewish wisdom speculation, is the direct descendant of this Heraclitean logos. As such, it serves as the controlling mechanism of the cosmos, and was thus identified with Fate or God (DL 7.134 [ $=S V F$ 2.300]). ${ }^{53}$ Once again, it is the thought of Cleanthes as evidenced by the Hymn to Zeus which offers the best parallel with Qohelet: "You (God) direct the universal logos which runs through all things...No deed is done on earth, God, without your offices...For you have so welded into one

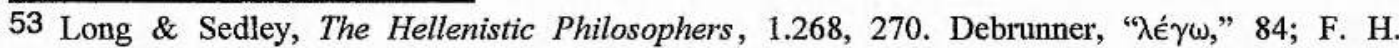
Sandbach (The Stoics [London: Chatto \& Windus, 1975] 72) captures the manifold meanings of the term logos as used by the Stoics when he explains that it means " the explanation of a thing, which may be the account or formula of its constitution, and the statement of its purpose. But to give the grounds for anything is a rational activity,...Perhaps 'plan' has something of the same ambiguity...(A Plan) implies the intentions of a rational being..." 
all things good and bad that they all share in a single everlasting account logos." (Hymn to Zeus, 11. 12-21 [=SVF 1.537]).

Significantly, the concept of logos as coextensive with wisdom and the divine work plays a part in Jewish wisdom speculation of the Hellenistic period. The work of Aristobulus (fl. 150 B.C.E.) indicates that acceptance of the concept of a logos had taken place at an early stage. Aristobulus (who is mentioned in 2 Macc 1:10) sought to interpret the LXX in the light of Greek (especially Stoic) philosophy and thus connected divine wisdom (бoфía) with logos in its guise as the cosmic ordering principle (Eusebius, Praep. Evang. 13.12.10-13).54 This connection between Wisdom and the logos is also notable in the Wisdom of Solomon. Here, God's logos and God's wisdom occur side by side describing the means by which the world and human beings were created (Wis 9:1-2). Philo used the term logos in its Stoic sense of a rationality which pervaded the cosmos (Heres 188; Fuga 111), and also connected it with wisdom (Leg All 165; Heres 191; Somn 2.242-45). According to Philo, the logos served as the medium through which the work of God found expression but was also the source of the universe's intelligibility. ${ }^{55}$ The use of the concept of logos in early Jewish writings is analogous to the way in which Qohelet uses the term ris for this too is a "rationale", apparently coextensive with "the work which is done under the sun" or "the work of God", but also the means by which Qohelet seeks to make sense of the universe around him.

The term logos is therefore used in the philosophical tradition represented by Heraclitus and the Stoics to denote a divine "account", a rationale which governs existence and through which existence can be understood by the wise individual. This "account" is in effect the sum total of human thought and action but is also an

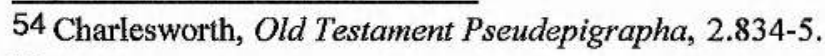

55 Tobin, "Logos," in $A B D$ 4.350-51. 
abstract concept, a controlling mechanism for the cosmos.

One might object that here we have a parallel thought between Qohelet and Greek philosophy rather than direct influence, but what is striking about Qohelet's usage is that he does not restrict the term the idea of a numerical account: in 9:10, for example it appears to mean "thought" (a meaning which it has nowhere else in Hebrew). 56 This is an example of wordplay analogous to that which we have seen in Heraclitus. Often, there is an ambiguity about whether Qohelet is using the term in an abstract or concrete sense (again, paralleled by Heraclitus's use of the term logos in his philosophy). It is, however, in its dual sense of rationality and rationale, placed parallel to wisdom, that Qohelet's most like the logos as it appears in Stoic and early Jewish thought.

The concept of the logos is used by Heraclitus and the early Stoics in all the ways in which Qohelet used the term Tring One is forced to conclude that there is more than a simple parallel of thought here. Qohelet has borrowed the concept of the $\log o s$ as the governing mechanism for existence and is aware of the many ways in which it is used. This in itself, if one accepts the Hellenistic dating of Ecclesiastes, need not be surprising. The logos as a concept was subsumed into Judaism very early on (appearing in Jewish Greek writings from 150 B.C.E. onwards), and played a major part in Jewish wisdom thereafter. We do not know how early this idea entered Judaism, and it is entirely possible that Qohelet came into contact with this idea and adapted it for his own ends. This need not detract from Qohelet's originality, nor

\footnotetext{
56 In Sir 42:3, in the later period (cf. Exod. Rab. 51; Deut. Rab. 4; t. B. Kam 10.21). In b. B. Bath 9b too, it has the meaning of a financial total. In only two locations of which $I$ am aware is there any figurative usage: $b$. B. Bath 78b and Aboth 4.22 both speak of a $a$ in in the sense of an account in contexts having to do with divine judgement. Thus, in b. B. Bath $78 \mathrm{~b}$ one may speak of God balancing a loss incurred in obeying the law by rewarding an individual (and a gain occasioned from breaking the law by punishing the individual) after death, and in $\mathrm{m}$. Aboth 4.22 of the individual rendering an account of one's deeds before God on the day of judgement. Nowhere is it used either with the range of meanings which Qohelet applies to it, nor in the same context.
} 
need it suggest that Qohelet's determinism does not ultimately stem from his Jewish background: his language elsewhere is fundamentally in line with other Hebrew deterministic writings of this time. It is, however, precisely at such interfaces between different cultures that the borrowing of general ideas is most likely. In this case, it is the specific contexts in which the concept is expressed by Qohelet which suggests that the connection between

\title{
IV. History
}

An important part of the Stoic message focusses on the idea that history is repeated in periodic cycles, and some commentators have argued that Qohelet echoes this idea in Eccl 1:4-11.57 Specifically, Qohelet states in Eccl 1:9-10:

\author{
That which has been is that which will be, \\ That which has been done is that which will be done: \\ There is nothing new under the sun. \\ Is there a thing of which it may be said "See, this is new?" \\ It has already been in ages which were before us.
}

Gammie rightly goes on to draw a parallel to the Stoic statement of Cicero, although some caution should be exercised since Cicero was writing in the first century B.C.E. 58

\begin{abstract}
If there were some human being who could see with his mind the connection of all causes, he would certainly never be deceived. For whoever grasps the causes of future things must necessarily grasp all that will be...The passage of time is like the unwinding of a rope, bringing about nothing new.
\end{abstract}

(Cicero, De Divinatione 1.127 [SVF 2.944])

\footnotetext{
57 Gammie, "Stoicism and Anti-Stoicism in Qoheleth," 174-176; Most recently this position has been adopted by Levine ("The Humor in Qohelet," 78-79).

58 Gammie, Ibid., 176.
} 
It may be objected that the idea that "there is nothing new" in existence is the sort of general thought which might easily be arrived at independently by different people in their consideration of life. As we shall see however, the content of the rest of this passage supports the idea that Qohelet is borrowing from Greek, and specifically Stoic, thought.

The majority of commentators already accept, albeit tacitly, some form of Greek influence when they point out the fact that Qohelet's depiction of the cycles followed by the wind, rivers, sun and earth itself makes use of the doctrine of the four elements. 59 This idea of the cosmos and everything therein being composed of these elements was canonical in Greek thought, and in Greek thought alone: it was also a major feature of Stoic philosophy (DL 7.136 [SVF 1.102]; 7.137 [SVF 2.580]; Nemesius 164.15-18 [SVF2.418]; Plutarch, Comm. not. 1085c-d [SVF 2.444]). The doctrine of the four elements is also found at the very earliest stages of Stoic thought. Stobaeus, a Greek anthologist writing in the fifth century C.E., states:

Chrysippus has the following views on the elements formed out of substance, following Zeno the leader of the school. He says that there are four elements $<$ fire, air, water, earth, out of which everything is composed-animals,> plants, the whole world and its contents-and that they are dissolved into these.

(Stobaeus 1.129.2-3 [SVF 2.413])

Qohelet's use of this concept is therefore of some significance for the argument that Ecclesiastes is a product of the Hellenistic era. Again, one might argue that Qohelet's mention of earth, fire (sun), air (wind) and water is coincidental.

59 Ibid., 174; Crenshaw, Ecclesiastes, 62; Whybray, Ecclesiastes, 39; Lohfink, Kohelet, 22. This common interpretation was seemingly first advanced by Ibn Ezra who was heavily influenced by Aristotelian philosophy (Gordis, Koheleth: The Man and His World, 56-57; Zimmerli, Prediger, 143; Hertzberg, Prediger, 61; S. Japhet, "Goes to the South and turns to the North" [Ecclesiastes 1:6] The Sources and History of the Exegetical Traditions," JSQ 1 [1994] 319). Fox is in a minority in understanding the term האר as referring not to the earth as such but to humanity as a whole, of which each generation forms a part (Qohelet and His Contradictions, 171). 
Against this, however, not only are each of the four elements mentioned in turn, they serve as an initial illustration of Qohelet's thesis that "everything is הבל" (1:2) as they do of the statement that "all things are full of labour" (1:8). Both statements presuppose that 1:4-7 represents something more than four isolated examples of natural forces at work. Only by understanding the four elements in their Greek/Stoic role as being the basic building blocks for all things can one understand the logic of Qohelet's jump from the use of these four examples of the elements in their natural (i.e. unmixed) state, showing how each one engages in ceaseless activity, to the claim that "all things" are full of labour. Indeed, just as Qohelet does in 1:8, Cleanthes drew a parallel between the ceaseless movement of the four elements in the cosmos and the human frame. 60

Qohelet, however, also demonstrates influence from his own Semitic background in the way that these elements are depicted. The earth cannot be said to "move" as such, and so ceaseless activity in this realm is shown by the generations of human beings dying and coming to life.61 Chrysippus argued that animals were made up of all four elements. Qohelet sees earth as their primary element, in line with general Hebrew thought $(3: 20 ; 12: 7 \mathrm{cf}$. Gen $2: 7 ; 3: 19)$ and thus the cycle of birth and death (or death and birth) serves as an example of unending activity in the realm of the element earth.

Many commentators have also pointed out the parallel between Qohelet's statement that "all rivers flow to the sea yet the sea is never full" (1:7) with that of Aristophanes, who remarks "The sea, though all rivers flow to it, increases not in

60 Gould, The Philosophy of Chrysippus, 35.

61 Ogden argues against this interpretation, although it is upheld by almost all commentators. For him, the term דור refers to the "generations" (i.e. individual cycles) of the remaining three elements; fire, wind and water ("The Interpretation of דור in Ecclesiastes 1.4," 91-92). 
volume" (The Clouds, 1294 [cf. Lucretius 6.608]).62 The same commentators have, generally speaking, been rather more cautious in drawing parallels between Qohelet's apparent application of these cycles to history with the Stoic doctrine of the periodic repetition of events. Thus, the Stoics held that fate was so constructed that the whole of history, down to the smallest detail, would be repeated periodically. One of the strangest consequences of this idea was that in order for history to repeat itself, the same people had to appear in it and thus every person who has ever lived would be reborn:

Chrysippus...when speaking of the world's renewal, drew the following conclusion: 'Since this is so, it is evidently not impossible that we too after our death will return to the shape we now are, after certain periods of time have elapsed.'

(Lactantius, Div. inst., 7.23 [SVF 2.623])

The same idea is also attributed to the Stoics in Nemesius 309.5-311.2 [SVF 2.625]; Eusebius, Praep. evang. 15.19.1-2 [SVF 2.599]; Origen, Contra Celsum 4.68, 5.20 [SVF 2.626] and many other sources, although the sources agree in its attribution to Chrysippus. Qohelet certainly does not suggest that the cycles of the four elements are indicative of such a periodic repetition of history. However, his use of these cycles of the elements before the statement that "there is nothing new under the sun" (1:9) is evidently of some significance.

Certainly, Hertzberg is right in pointing out that Qohelet's thought here is unique in the Hebrew Bible (Ps 96:1; Jer 31:22, 31; Isa 43:19; 65:18).63 This becomes more significant if it is remembered that in most of the previous examples, it is God who does a "new thing." In Ecclesiastes, the actions that occur in the human

62 Gordis, Koheleth: the Man and His World, 206; Plumptre, Ecclesiastes, 106; Zimmerli, Der Prediger, 143.

63 Hertzberg, Der Prediger, 62. 
realm are also divinely controlled, yet there is "nothing new."

However, the majority consensus views Qohelet's statement that "there is nothing new under the sun" as referring in the most general way to human actions.64 One might sing a new song, but it still falls into the category "song." One might make a new covenant but this too conforms to an archetypal "covenant." In this sense the events which go to make up existence do repeat themselves. One problem with this view is that in 1:10 Qohelet forestalls possible arguments against his statement by remarking that "there is no remembrance of former things." The repetition cannot therefore be one of general "archetypes" or of general actions as Fox supposes: these archetypes are well known to humanity. Based on the contextual evidence, one can come to no other conclusion than that Qohelet is referring to specific actions or events which are being repeated. This brings the passage much closer to the literal repetition evident in the depiction of the four elements in 1:4-7, and also to the Stoic view of history.

The essential difference between Qohelet and the philosophy of the Stoics in this area lies in the Stoic claim that the world was subject to periodic conflagration (ejkpuvrwsi1) which recreated the world anew, after which history would repeat itself down to the smallest detail (Eusebius, Praep. evang. 15.14.2 [SVF 1.98]; DL 7.141 [SVF 2.589]). Qohelet, on the other hand, clearly states that "the earth remains forever" (1:4).

There is no denying that this doctrine appears to have been advanced by the first three leaders of the Stoic school. However, it remained extremely controversial and subsequent leaders were forced to revise their arguments, either withholding judgement on the question or altogether denying the doctrine of ecpyrosis. Thus Philo writes:

64 Fox, Qohelet and his Contradictions, 172-72; Murphy, Ecclesiastes, 8. 
Boethius of Sidon and Panaetius...gave up the conflagrations and regenerations, and deserted to the holier doctrine of the entire world's indestructibility. Diogenes too is reported to have subscribed to the doctrine of the conflagration when be was a young man, but to have had doubts in his maturity and suspended judgement.

(Philo, Aet. mundi 76-77)

The philosophers mentioned in this passage Boethius (2nd cent.), Panaetius (c. 185110) and Diogenes of Babylon (c. 220-152) are too late to provide a reasonable parallel with a third century dating for Ecclesiastes but are nevertheless indicative of a debate going on within Stoicism at an early date concerning the doctrine of ecpyrosis. More significantly, even among the earliest leaders there was no agreement about the precise nature of the conflagration: Cleanthes argued that the world would change into flame, while his pupil Chrysippus suggested that it changed into light (Philo, Aet. mundi 90 [= SVF 1.511]). Under the circumstances, it is not impossible that Qohelet had contact with the Stoic theory of cycles without accepting the idea of ecpyrosis as indeed both Gammie and Levine have previously claimed.

\section{Conclusion}

In conclusion, we can perhaps say that although the differences between the thought of Qohelet and the earliest Stoics are many, there are also significant parallels which are sufficiently frequent and close to suggest some kind of connection. Firstly, Qohelet appears to diverge to some extent from his Jewish background in emphasising God's determination of human thought and action rather than his foreknowledge of the same. Free will in Ecclesiastes appears extremely limited, in a way which is rare elewhere in early Jewish literature.

Qohelet's position on moral/ethical free will is also similar in many respects 
to that of the second leader of the Stoic school, Cleanthes: the righteous are stated to be under God's deterministic control, while the wicked are said to act outside it. Indeed, Qohelet may even cite Cleanthes's dictum about the nature of the Stoic god against him. Whereas the Stoic god is said to "make crooked things straight", Qohelet's god does the exact opposite and makes that which is straight crooked. Qohelet appears to demonstrate some knowledge of the deterministic mechanism which the Stoics called the logos, and which he calls by an equivalent term, the חשבון.

Finally, Qohelet shows an awareness of the four elements which were canonical in Greek thought, and has a cyclical view of history, similar in many respects to that of the Stoics. Qohelet's partial acceptance of Stoic thought, evident perhaps in his veiled criticism of Cleanthes, may also be reflected in his apparent rejection of the idea of ecpyrosis.

Qohelet is not a Stoic. This much is clear. This need not mean, however, that he was ignorant of its doctrines, nor that some of these ideas are not reflected in his work. Since the evidence for the date of Ecclesiastes in general points to the Hellenistic period, this means that some attempt must be made to understand Qohelet's thought against the cultural backdrop of Hellenistic thought, both Jewish and Greek. 65 The work of Qohelet, I would argue, owes something to both milieus, although as this thesis has also demonstrated, he can and frequently does view things from a standpoint unique to himself.

65 Gammie's justification for his attempt to link Stoicism with Qohelet's thought is worth citing in this regard: "even though the exegete may fall into erroneous expositions (should his or her assessment of date or background subsequently be proven to be wrong), the worse error would be to attempt to interpret with little or no reference to the relation of the biblical author to hs or her own cultural environment" ("Stoicism and Anti-Stoicism in Qoheleth," 173). This view is also echoed to some extent by Fox (Qohelet and His Contradictions, 16). 


\section{Chapter 10 Conclusion}

The object of this thesis has been to demonstrate that Qohelet is a determinist and that his work is a product of the Hellenistic period. In Chapter 1, the evidence for a Hellenistic dating was reviewed, and the current scholarly consensus upheld, although with some reservations. Subsequently, several of the key terms (חלק, מששפט, עת , פגע ,מקרה) occurring in passages which have been traditionally interpreted in a deterministic sense were examined (Chapter 2). Perhaps the most important conclusion of this chapter for the future direction of studies on Ecclesiastes is that Qohelet does not consider chance to be a force operative in existence, contrary to the assertion of many commentators.

The term מקרה, contrary to its usage elsewhere in the Hebrew Bible, has the sense of "(unpredictable/uncontrollable) happening" rather than "chance happening", for it is used primarily of death, which is clearly stated by Qohelet to be predetermined. Likewise, פגע, which is translated "chance" by many commentators, is in fact used elsewhere only of some form of encounter or meeting which is planned by at least one of the parties thereto. When used of an event which befalls human beings, as Qohelet does, one may conclude that it is of an event which is predetermined.

Many commentators already understand the term עת in the sense of a time for human action which is predetermined by God, and in accordance with which human beings must act. A consideration of the contexts in which Qohelet uses this term concludes that this is indeed the case, and that Qohelet therefore advances the concept of a far-reaching form of determinism over all, or nearly all, human activities. Related to this topic is the question of what Qohelet means when he speaks of 
"judgement" (משפט), particularly in the difficult passage 8:5-6. Following an examination of the two different interpretations currently advanced by modern commentators, that Qohelet either refers to the judgement of the wise man and his ability to act at the appropriate time, or to the idea that at a certain predetermined moment, God will enact a traditional judgement on human beings, it was concluded that neither interpretation answered the problems evident both in this passage and in the wider context. A new interpretation was therefore advanced in which Qohelet understood the divinely determined times which befall human beings as a form of judgement. This was demonstrated to fit Qohelet's worldview and to all contexts in which שפ is used of God's activity except 11:9b, thus supporting the view of many commentators that $11: 9 \mathrm{~b}$ is a gloss.

Finally, Qohelet's usage of the term חלק was considered: this usage was shown to be fundamentally different to that of other texts in the Hebrew Bible. Primarily, this dfference was apparent in the fact that God gives "portion" to the individual. More remarkably, however, this "portion" was shown to be not so much connected with material goods as with human emotions. The "portion" which God gives to humanity is joy, love, hate, envy. Qohelet's deterministic worldview therefore finds clear expression in the idea that God is responsible for the emotions which human beings feel as well as the actions which they perform.

The question of the meaning of the term עת is perhaps the most important one for establishing the nature and extent of Qohelet's deterministic worldview. If one can say that Qohelet uses the term עת in the sense of predetermined time in $3: 1$, "for everything there is a season, a time for every matter under heaven" and in the list of human activities in $3: 2-8$, then one can say that Qohelet is in the truest sense of the word a determinist. This position has been recently challenged by Joseph 
Blenkinsopp, and to this extent a response to Blenkinsopp's paper formed the body of Chapter 3. Blenkinsopp's thesis, that Qohelet is a determinist (in a looser sense of the word) but that this was not the idea which 3:2-8 was intended to express, was refuted on the basis of evidence brought out in the previous chapter, joined with fresh evidence to support the idea that 3:2-8 was Qohelet's own work and that it was intended to express a deterministic worldview.

In Chapter 4, attention was directed at a problem hitherto unnoticed or ignored by modern commentators. Many of those who support the idea that Qohelet is a determinist argue for the equivalence of "the work of God" and "the work which is done under the sun." Yet current translations of 8:17a translate the particle $כ$ as if it were introducing an object clause, so that Qohelet in this text apparently states that the work of God is to prevent human beings from finding out the work which is done under the sun. An examination of the form in which such object clauses are expressed in Hebrew in GKC, however, led to the conclusion that it had been wrongly classified and that the particle should therefore be translated affirmatively (i.e. "surely"). This finding reinforces the argument that "the work of God" and "the work which is done under the sun" are more or less equivalent phrases, and thus bolsters the argument that Qohelet is a determinist in the true sense of the word.

Chapter 5 produced two new contributions to the debate on the nature and date of Ecclesiastes. Seow has recently argued powerfully against the current consensus which would make the book of Ecclesiastes a product of the early Hellenistic period. His argument that Qohelet's work can only be dated to the Persian period hinges, however, on Qohelet's use of $\sqrt{ }$ in its legal/technical sense of "(delegated) authority" or "proprietorship", a sense which he claims falls out of use after the Persian period. A closer examination of this claim found that, on the 
contrary, examples of $\sqrt{ }$ של used in this sense could clearly be seen in the books of Daniel and Ben Sira, both products of the early Hellenistic period. Moreover, this technical sense of the root occurs several times in Hebrew in the Talmud, in Syriac slave sale documents of the early Christian era, in Mediæval Aramaic marriage contracts and finally in a Yiddish proverb which has been used up to modern times. These findings allow us to conclude that Qohelet may well have written his work in the Hellenistic period, and indeed the figurative use in which Qohelet uses Vטל has clear affinities with the usage in the Hellenistic book of Daniel, in contrast to the purely pedestrian sense in which it is found in Persian period texts.

Consideration was then given to Qohelet's use of the root in the light of Seow's claims as to its meaning. It was found that by and large, God is seen by Qohelet as the distributor of שלטון to human beings (in contrast to Seow, who considers it to be, in the main, allocated by earthly authorities). This finding has particular relevance for understanding Qohelet's worldview, since Qohelet uses this idea of divinely allocated שלמטן in the context of finding happiness, but also to explain human evil and inequities in an existence which he believes to be divinely controlled. This idea of שלטון may therefore be understood as a limited form of free will. This in turn explains why Qohelet can advise his disciple on the manner of finding happiness (when "there is an appointed time for every matter"), and also shows that Qohelet gave some thought to the problem of human evil in the context of determinism. By explaining evil and inequity as a product of human volition, the deity is to some extent distanced (although not wholly absolved of responsibility for) the existence of these things. It was also noted that Qohelet uses a special legal formula ("he does whatever he chooses") of the king and apparently considers the king to have a special relationship with God. Kings are effectively free of the deterministic mechanism 
which otherwise controls existence. This in turn may explain, at least to some extent, the royal fiction in Chapters 1 and 2 and the paradox of how Qohelet is free to conduct his investigations when all is predetermined, although such an idea is not made explicit therein.

In Chapter 6, consideration was given to what is perhaps the most difficult passage in the book of Ecclesiastes (7:23-29). Typically, the woman who appears in this passage has been regarded in one of two ways. The first is that she is a stereotypical "wicked" woman in line with other misogynistic depictions of such women in Proverbs or Ben Sira. The other has been that Qohelet quotes such an idea of woman in order to argue against it. A careful consideration of the entrapment imagery associated with the woman, however, revealed that Qohelet depicts her as a divine agent, for the nets which she uses to entrap men are almost always associated with Yahweh's judgement elsewhere in the Hebrew Bible. Nor could the reference in 7:26 be considered appropriate only to "a certain type of woman", for her activity was shown not to affect the stray individual, but the many. Whether her potential victim was caught or escaped was wholly in the hands of God. Thus, Qohelet's depiction of woman demonstrated that there was indeed "a time to love", in line with Qohelet's statement in 3:8.

Having given consideration to the nature of the woman, who is apparently a morally neutral figure, and whose actions (like the rest of humanity) are determined by God, attention was turned to the purpose for which the woman was introduced into this text, which essentially admits Qohelet's failure to achieve the kind of knowledge of exitence which he seeks. Tentatively, it was concluded that the woman acts as a defence against human beings gaining mastery over existence and thus finding the work of God. She is symbolic of the pleasure which God allots to 
humanity in order to keep them occupied. As far as Qohelet's own search goes (for Qohelet is apparently one of the lucky few who have escaped), it would appear that the danger which the woman represents prevents him from carrying out his purpose.

These ideas lead on naturally to the subject of Chapter 7, in which Qohelet's attitude towards human joy is considered, as evidenced in those texts in which Qohelet makes the recommendation to seek out pleasure (as defined by Whybray and de Jong). Although this subject is considered to some extent in Chapters 2, 5 and 6 , the evidence provided in this chapter shows that while a certain amount of human free will is presupposed in the seeking of pleasure, human beings remain entirely dependent on God for its attainment. This is particularly underlined by Qohelet's reference to pleasure as "the gift of God." The conclusion reached in this chaper is fundamentally in line with the current thinking of the major commentators of Ecclesiastes (e.g. Crenshaw, Whybray), who themselves are only the latest in a long line of commentators who have understood Qohelet's thinking thus.

Having to some extent reconstructed Qohelet's worldview in the preceding chapters, the final two chapters of this thesis turned to consider the question of how this view of existence meshes with the background in which Qohelet is supposed to have lived and wrote. In Chapter 8, Qohelet's deterministic depiction of life was considered in the light of Jewish thought. It was concluded that in general there is no consistent belief in determinism in the Hebrew Bible, although a few scattered ideas consistent with this concept may be found therein. There is, however, a strongly deterministic element to be found in early Jewish extra-biblical literature from the Hellenistic period on. This is particularly true of apocalyptic literature, a fact which has led many to argue that this genre stems ultimately from the wisdom tradition in which Qohelet wrote. Again, this apparent flowering of the idea of determinism in 
the Hellenistic period would appear to support the consensus dating of Ecclesiastes to this time. Similarities were, moreover, noted between the way that both Qohelet and the author of the book of Daniel expressed this concept of determinism. The thought of Qohelet also was also demonstrated to show some affinity with Sirach in that both consider the problem of human wickedness in the light of determinism and allude to the idea that God may thereby be construed by the wicked as supporting their wrongdoing.

Nevertheless, several important differences were noted between Qohelet's consideration of the problem of evil and that of the normative tradition which is expressed by other Jewish writers. In other texts of this time, where consideration is given to the problem of evil at all, total free will for human beings is asserted in the moral/ethical sphere. Yet this clearly contradicts the idea that God may determine the course of history or the life of the individual, for it is through the choices made by human beings that history is made.

In line with the similarities noted beween Ecclesiastes and Hellenistic literature in previous chapters, suggesting that Qohelet's work is a product of this time, Chapter 9 then considers the question of a possible interface between the form of determinism advanced by the Stoics in the third century B.C.E. Discussion in the first part of this chapter was limited to those areas in which Qohelet appears to diverge from contemporary Jewish thought, specifically the question of how human evil can be reconciled with a benevolent deterministic God.

Again, general similarities were noted between the form of determinism advanced by the Stoics and that of Qohelet. These are less striking by and large than the similarities with Jewish thought. Unlike Jewish writers of the Hellenistic period, however, the Stoics paid a great deal of attention to the question of how human evil 
and wickedness may be reconciled with a belief in determinism. Qohelet makes no such convoluted or complicated attempts to reconcile the two as does the third leader of the Stoic school, Chrysippus (232-208 B.C.E.), with whom his work is most often linked. An analogous explanation for the presence of evil was, however, found in the work of Cleanthes (261-232 B.C.E.), the predecessor of Chrysippus, and a contemporary of Qohelet according to the current consensus for the date of Ecclesiastes. According to Cleanthes, God was held to control all things which happened on earth, with the exception of those actions which were performed by the wicked. This thought is a good parallel to that of Eccl 9:1 in which Qohelet sees God's activity as being expressed through "the wise and the righteous and their works." It is an open question however, as to whether this is an example of influence or of two original thinkers reachng the same conclusion independently.

That the former may be the case, however, and that Qohelet may have been aware of the basic ideas of Stoic determinism is suggested by his use of the term Elsewhere in Hebrew and cognate languages, this term typically means "account" in a numerical sense. Qohelet, however, uses it to describe the system by which the events of life play themselves out. As such, the חשבון appears to be coextensive with "the work of God" or "the work which is done under the sun", but it is also the means by which these things may be understood. Qohelet also uses the term in a concrete (numerical) sense to refer to the account which he himself hopes to form, and of the accounts which others form of existence. Finally, he also uses it in the sense of "thought", a meaning which it has nowhere else in Hebrew, although this meaning is implicit in Vשem from which the noun is derived. Qohelet's use of this noun is unique in Hebrew, but the meanings with which he invests it is almost exactly that in which the corresponding Greek term logos occurs in the philosophies 
of Heraclitus and the Stoics. As such, Qohelet's usage appears to be more than a parallel of thought, but to be indicative of contact with this, the most fundamental aspect of Stoic determinism. This need not detract from Qohelet's originality, nor need it imply that Qohelet takes on board the ideas of Stoicism wholesale. In many respects, his thought differs quite fundamentally from that of the Stoic philosophers, although other similarities with Stoic thinking (his reference to the four elements, his apparently cyclical view of history) have in the past been noted. The evidence adduced in this thesis supports the idea that Qohelet's thought is primarily to be related to his Jewish background. At the same time, however, those aspects of Greek thought (limited though they may be) which find expression in his work should not be ignored. 


\section{Bibliography}

\section{H. W. Attridge}

"Josephus and his Works," in M. E. Stone (ed.), Jewish Writings of the Second Temple Period (Assen: Van Gorcum; Philadelphia: Fortress, 1984) 185-232.

\section{E. V. Arnold}

Roman Stoicism (New York: Humanities, 1958)

\section{$\underline{\text { S. de Ausejo }}$}

"El género literario del Ecclesiastés," EstBib 7 (1948) 394-406.

K. Baltzer

"Women and War in Qohelet 7:23-8:1a," HTR 80 (1987) 127-32.

G. A. Barton

Ecclesiastes (ICC; Edinburgh: Clark, 1908).

\section{A. Barucq}

Ecclésiaste (Paris: Beauchesne, 1968)

E. Bickerman

Four Strange Books of the Bible (New York: Schoken, 1967).

\section{J. Blenkinsopp}

"Ecclesiastes 3.1-15: Another Interpretation," JSOT 66 (1995) 55-64.

\section{J. den Boeft}

Calcidius on Fate: His Doctrine and Sources (Brill: Leiden, 1970).

\section{G. H. Box}

The Apocalypse of Abraham (London: SPCK; New York: Macmillan, 1918).

G. Braumann

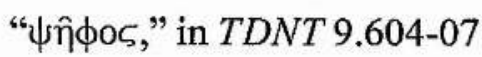




\section{R. Braun}

Kohelet und die frühhellenistische Popularphilosophie (BZAW 130; Berlin \& New York: de Gruyter, 1973).

\section{A. Brenner}

"Some Observations on Figurations of Woman in Wisdom Literature," in A. Brenner (ed.), A Feminist Companion to Wisdom Literature (Sheffield: Sheffield Academic, 1995) 50-66.

\section{$\underline{\text { K. Brockelman }}$}

Lexicon Syriacum (Hildesheim: Georg Olms, 1966).

\section{F. C. Burkitt}

"Is Ecclesiastes a Translation?" JTS 23 (1921-22) 22-27.

G. R. Castellino

"Qohelet and His Wisdom," CBQ 30 (1968) 15-28.

\section{J. H. Charlesworth (ed.)}

The Old Testament Pseudepigrapha (2 Vols; London: Darton, Longman \& Todd, 1985).

\section{J. J. Collins}

"Cosmos and Salvation: Jewish Wisdom and Apocalyptic in the Hellenistic Age," HR 17 (1977) 121-42.

The Apocalyptic Imagination (New York: Crossroad, 1984).

\section{A. Condamin}

“Etudes sur l'Ecclésiaste," RB 9 (1900) 30-44.

\section{A. D. Corré}

"A Reference to Epispasm in Koheleth," VT 4 (1954) 416-18.

\section{A. Cowley}


Aramaic Papyri of the 5th Century B.C. (Oxford: Clarendon, 1923).

\section{J. L. Crenshaw}

"The Eternal Gospel (Eccl 3:11)," in J. L. Crenshaw \& J. T. Willis (eds.), Essays in Old Testament Ethics (New York: Ktav, 1974) 23-55.

Old Testament Wisdom: An Introduction (Atlanta: John Knox, 1981).

Ecclesiastes (OTL; Philadelphia: Westminster, 1987).

F. M. Cross

"The Oldest Manuscripts from Qumran," JBL 74 (1955) 147-72.

"The Discovery of the Samaria Papyri," BA 26 (1963) 110-20.

"Samaria Papyrus 1: An Aramaic Slave Conveyance of 335 B.C.E. Found in the Wadi ed-Daliyeh," in Nahman Avigad Volume, ErIsr 18 (Jerusalem, 1985) 7-17.

"A Report on the Samaria Papyri," in J. A. Emerton (ed.), Congress Volume, Jerusalem, 1986 (VTSup 40; Leiden: Brill, 1988) 17-26.

\section{Dahood}

"Canaanite-Phoenician Influence in Qoheleth," Bib 33 (1952) 30-52, 191-221.

"Qoheleth and Recent Discoveries," Bib 39 (1958) 302-318.

"Qoheleth and Northwest Semitic Philology," Bib 43 (1962) 349-365.

"Canaanite Words in Qoheleth 10,20," Bib 46 (1965) 210-212.

"The Phoenician Background of Qoheleth," Bib 47 (1966) 264-282.

\section{J.R. Davila}

"Qoheleth and Northern Hebrew," Maarav 5-6 (1990) 68-87.

\section{A. Debrunner}

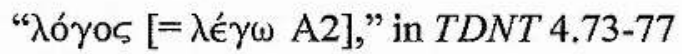

\section{F. Delitzsch}

Commentary on the Song of Songs and Ecclesiastes (Leipzig: Dörffling \& Franke, 1875; Edinburgh: Clark, 1877; reprint, Grand Rapids: Eerdmans, 1982).

\section{Devine}


Ecclesiastes or the Confessions of an Adventurous Soul (London: Macmillan, 1916).

\section{B. C. Dietrich}

Death, Fate and the Gods (London: Athlone, 1965)

G. Dossin

“Une Nouvelle Lettre d'el Amarna," RA 31 (1934) 126-29.

\section{G. R. Driver}

"Problems and Solutions," VT 4 (1954) 225-45.

\section{A. J. Droge}

"Suicide," in $A B D$ 6.227-31.

\section{A. J. Droge \& J. D. Tabor}

A Noble Death: Suicide and Martyrdom among Jews and Christians in Antiquity (San Francisco: Harper-Collins, 1992).

F. Ellermeier

Qohelet (Herzberg: Erwin Jungfer, 1967).

H. A. Fischel

"Stoicism," in EncJud 15.410.

\section{V. Fox}

Qohelet and his Contradictions (JSOTSup 71; Sheffield: JSOT, 1989).

M. V. Fox \& B. Porten

"Unsought Disciveries: Qohelet 7:23-8:1a," HS 19 (1978) 26-38.

\section{C. Fredericks}

"Life's Storms and Structural Unity in Qoheleth 11.1-12.8," JSOT 52 (1991) 95-114.

\section{W. J. Fuerst}

The Books of Ruth, Ecclesiastes, the Song of Songs, Lamentations (Cambridge: C.U.P., 1975). 


\section{K. Galling}

Studien zur Geschichte Israels im persischen Zeitalter (Tübingen: Mohr, 1964).

Der Prediger (HAT 18; Tübingen: Mohr, 1969).

\section{J. G. Gammie}

"Stoicism and Anti-Stoicism in Qoheleth," HAR 9 (1985) 169-87.

\section{B. Gemser}

"The Instructions of 'Onchsheshonqy and Biblical Wisdom Literature," in Congress Volume, Oxford, 1959 (VTSup 7; Leiden: Brill, 1960) 102-28.

\section{G. Giesen}

"םרם (II)," in TDOT 5.200-203

\section{H. L. Ginsberg}

Studies in Koheleth (New York: Jewish Theological Seminary of America, 1950).

"The Structure and Contents of the Book of Koheleth," in M. Noth \& D. W. Thomas (eds.), Wisdom in Israel and the Ancient Near East (VTSup 3; Leiden: Brill, 1955) 138-49.

Qoheleth (Jerusalem \& Tel Aviv: Newman, 1961).

\section{Ginsburger}

"Review of Das Targum zu Koheleth nach sudarabischen Handschriften herausgegeben von Alfred Levy," ZDMG 59 (1905) 717.

\section{E. Glasser}

Le procès du bonheur par Qohelet (Paris: Cerf, 1970).

\section{J.A. Goldstein}

"The Syriac Bill of Sale from Dura-Europos," JNES 25 (1966) 11-12.

\section{Gómez Aranda}

El Comentario de Abraham Ibn Ezra al Libro del Eclesiastés (TECC 56; Madrid: CSIC, 1994). 
$\underline{\text { R. Gordis }}$

"Was Koheleth a Phoenician? Some Observations on Methods in Research," JBL 71 (1955) 105-9.

Koheleth: The Man and His World (New York: Bloch, 1968).

\section{J. B. Gould}

The Philosophy of Chrysippus (Leiden: Brill, 1970).

"The Stoic Conception of Fate," JHI 35 (1974) 17-32.

\section{J. A. Grassi}

"Child, Children," in $A B D$ 1.904-7.

\section{W. C. Greene}

Moira: Fate, Good and Evil in Greek Thought (Cambridge: Harvard University, 1944).

\section{M. Gropp}

"The Origin and Development of the Aramaic salliț Clause," JNES 52 (1993) 3136.

\section{H. Grotius}

Annotationes in Vetus Testamentum (ed. G. Vogel; Halae: Curt, 1875-76).

W. K. C. Guthrie

History of Greek Philosophy (6 Vols; Cambridge: C.U.P., 1962-81).

M. Hengel

Judaism and Hellenism (2 Vols; London: SCM, 1974).

\section{H. Heidland}

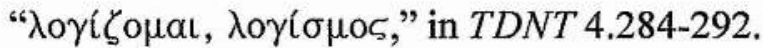

\section{H. W. Hertzberg}

Der Prediger (KAT XVI, 4; Leipzig: Scholl, 1932). 


\section{F. Hitzig}

Der Prediger Salomo's (KHAT; Leipzig: Weidmann, 1847).

\section{A. Hurvitz}

"The History of a Legal Formula: kōl 'ăšer hāpēṣ căsāh (Psalms CXV 3, CXXXV 6),"VT 32 (1982) 257-67.

\section{S. Japhet}

"Goes to the South and turns to the North" (Ecclesiastes 1:6) The Sources and History of the Exegetical Traditions," JSQ 1 (1994).

\section{S. Japhet \& R. B. Salters}

Rashbam on Qohelet (Jerusalem: Magnes, 1985).

M. Jastrow

A Gentle Cynic (Phildelphia: Lippincott, 1919).

\section{Jastrow}

A Dictionary of the Targumim, the Talmud Babli and Yerushalmi, and the Midrashic Literature (New York: Judaica, 1992).

\section{R. K. Johnston}

"Confessions of a Workaholic: A Reappriasal of Qoheleth," $C B Q 38$ (1976) 14-28.

\section{E. Jones}

Proverbs and Ecclesiastes (London: SCM, 1961).

\section{S. de Jong}

"A Book on Labour: The Structuring Principles and the Main Theme of the Book of Qohelet," JSOT 54 (1992) 107-16.

"Qohelet and the Ambitious Spirit of the Ptolemaic Period," JSOT 61 (1994) 85-96. "God in the Book of Qohelet: A Reappraisal of Qohelet's Place in Old Testament Theology," VT 47 (1997) 154-67. 


\section{O. Kaiser}

"Judentum und Hellenismus," VF 27 (1982) 69-73.

"Determination und Freiheit beim Kohelet/Prediger Salomo in der frühen Stoa," NZSTh 31 (1989) 251-270.

\section{Kidner}

A Time to Mourn and a Time to Dance (Leicester: Inter-Varsity, 1976).

\section{G. S. Kirk}

Heraclitus: The Cosmic Fragments (Cambridge: C.U.P., 1954).

H. Kleinknecht

" $\lambda \epsilon ́ \gamma \omega \mathrm{B}$, , in TDNT 4.77-91.

\section{A. Knibb}

"You are indeed Wiser than Daniel': Reflections on the Character of the Book of Daniel," in A. S. Van der Woude (ed.), The Book of Daniel in the Light of New Findings (BETL 106; Leuven: Leuven University/Peeters, 1993) 399-411.

\section{P. S. Knobel}

The Targums of Job, Proverbs, Qohelet (Edinburgh: Clark, 1991).

\section{H. Koester}

History, Culture and Religion of the Hellenistic Age (Philadelphia: Fortress, 1984).

\section{E. G. Kraeling}

The Brooklyn Museum Aramaic Papyri: New Documents of the Fifth Century B.C. from the Jewish Colony at Elephantine (New Haven: Yale University, 1953).

\section{J. L. Kugel}

"Qohelet and Money," CBQ 51 (1989) 32-49.

E. Y. Kutscher

"New Aramaic Texts," JAOS 74 (1954) 233-48. 


\section{K. J. A. Larkin}

The Eschatology of Second Zechariah: A Study in the Formation of a Mantological Wisdom Anthology (Kampen: Kok Pharos, 1996).

\section{A. Lauha}

Kohelet (BKAT 19; Neukirchen-Vluyn: Neukirchener, 1978).

\section{A. A. Di Lella}

"Wisdom of Ben Sira," in $A B D$ 6.931-45.

\section{E. Levine}

The Aramaic Version of Qohelet (New York: Hermon, 1978).

"The Humor in Qohelet," ZAW 109 (1997) 71-83.

\section{J. A. Loader}

"Qohelet 3:2-8 - A 'Sonnet' in the Old Testament," ZAW 81 (1969) 240-42.

Polar Structures in the Book of Qohelet (BZAW 152; Berlin \& New York: de Gruyter, 1979).

\section{N. Lohfink}

Kohelet (Würzburg: Echter, 1980).

War Kohelet ein Frauenfeind? Ein Versuch, die Logik und den Gegenstand von Koh. 7:23-8:1a herauszufinden," in M. Gilbert (ed.), La Sagesse de l'Ancien Testament (BETL 51; Gembloux: Duculot; Leuven: Leuven University, 1979) 259-87.

"Melek, šallitt und môšelbei Kohelet und die Aufassungzeit des Buchs," Bib 62 (1981) $525-43$.

\section{A. A. Long \& D. N. Sedley}

The Hellenistic Philosophers (2 Vols; Cambridge: C.U.P., 1987).

\section{O. Loretz}

Qohelet und der Alte Orient: Untersuchungen zu Stil und theologischer Thematik des Buches Qohelet (Freiburg: Herder, 1964).

\section{W. McKane}


Proverbs (OTL; London: SCM, 1970).

\author{
A. H. McNeile \\ An Introduction to Ecclesiastes (Cambridge: C.U.P., 1904). \\ E. Mannebach \\ Aristippi et Cyrenaicorum Fragmenta (Leiden: Brill, 1961). \\ D. S. Margoliouth
}

"Ecclesiastes," in Jewish Encyclopcedia (New York/London: Funk \& Wagnalls, 1907) 5.32-34.

\title{
D. Michel
}

Qohelet (Darmstadt: Wissenschaftliche Buchgesellschaft, 1988).

Untersuchungen zur Eigenart des Buches Qohelet (BZAW 183; Berlin: de Gruyter, 1989).

\section{J. A. Montgomery}

"Notes on Ecclesiastes," JBL 43 (1924).

Daniel (ICC; Edinburgh: Clark, 1927).

\section{Morris}

Apocalyptic (London: Inter-Varsity, 1973).

\section{Y. Muffs}

Studies in the Aramaic Legal Papyri from Elephantine, Studia et Documenta ad Iura Orientis Antiqui Pertinenta, vol. 8 (Leiden: Brill, 1969).

\section{J. Muilenberg}

“A Qoheleth Scroll from Qumran," BASOR 135 (1954).

\section{H.-P. Müller}

"Mantische Weisheit und Apokalyptik" in Congress Volume, Uppsala, 1971 (VTSup 22; Leiden: Brill, 1972) 271- 80.

"Neige der althebräische 'Weisheit': Zum Denken Qohäläts," ZAW 90 (1978) 238-64. 
R. E. Murphy

Ecclesiastes (WBC23a; Dallas: Word, 1992).

\section{C. Nahm}

Selections from Early Greek Philosophy (New York: Meredith, 1962).

G. W. E. Nickelsburg

"Eschatology (Early Jewish)," in $A B D$ 2.579-594.

\section{T. Nöldeke}

"Bemerkungen zum hebräischen Ben Sira," ZAW 20 (1900) 81-94.

\section{G. S. Ogden}

"Qoheleth's Use of the 'Nothing is Better' Form," JBL 98 (1979) 341-50.

"Qoheleth IX 1-16," VT 32 (1982) 158-69.

"Qoheleth XI 7-XII 8: Qoheleth's Summons to Enjoyment and Reflection," VT 34 (1984) 27-38

"The Interpretation of in Ecclesiastes 1.4," JSOT 34 (1986) 91-92.

Qoheleth (Sheffield: JSOT, 1987).

\section{A. C. Pearson}

The Fragments of Zeno and Cleanthes (London: Clay, 1891).

\section{N. Porteous}

Daniel (OTL; London: SCM, 1979).

\section{Préaux}

Le monde héllenistique: La Grèce et l'Orient de la mort d'Alexandre à la conquête romaine de la Grèce (232-146 av. J.-C.) (Paris: Nouvelle Clio, 1978).

\section{E. Pfleiderer}

Die Philosophie des Heraklit von Ephesus, nebst Koheleth und besonders im Buch der Weisheit (Berlin: Reimer, 1886). 
E. H. Plumptre

Ecclesiastes (Cambridge: C.U.P. 1881).

E. Podechard

L'Ecclésiaste (Paris: Lecoffre, 1912).

J. J. Rabinowitz

Jewish Law: Its Influence on the Development of Legal Institutions (New York: Bloch, 1956).

\section{G. Von Rad}

"The Promised Land and Yahweh's Land in the Hexateuch," ZDPV 66 (1943) 191204 (= The Problem of the Hexateuch and Other Essays [Edinburgh \& London: Oliver \& Boyd, 1966] 79-93).

Wisdom in Israel (London, SCM, 1972).

\section{H. D. Rankin}

Sophists, Socratics and Cynics (Beckenham: Croom Helms, 1983).

\section{H. Ranston}

Ecclesiastes and the Early Greek Wisdom Literature (London: Epworth, 1925).

\section{E. Reesor}

The Nature of Man in Early Stoic Philosophy (London: Duckworth, 1989)

\section{E. Renan}

L'Ecclésiaste traduit de l'Hébreu avec une étude sur l'age et le caractère du livre (Paris: Levy, 1882).

\section{F. Rosenthal}

A Grammar of Biblical Aramaic (Wiesbaden: Harrassowitz, 1983).

\section{Rudman}

“A Contextual Reading of Ecclesiastes 4:13-16," JBL 116 (1997) 57-73.

"The Translation and Interpretation of Ecclesiastes 8:17a," JNSL 23/1 (1997) 1-9.

"Woman as Divine Agent in Ecclesiastes," JBL 116 (1997) 411-27. 
"Qohelet's Use of לפני," JNSL 23/2 (1997).

"The Anatomy of the Wise Man: Wisdom, Sorrow and Joy in the Book of Ecclesiastes," in A. Schoors (ed.), Qohelet in the Context of Wisdom (BETL; Leuven: Leuven University/Peeters, 1998).

"A Note on the Dating of Ecclesiastes," $C B Q 61$ (1999).

\section{S. Russell}

The Method and Message of Jewish Apocalyptic (OTL; London: SCM, 1964).

Divine Disclosure (London: SCM, 1992).

\section{R. B. Salters}

The Book of Ecclesiastes: Studies in the Versions and the History of Exegesis (Ph.D. Diss; St. Andrews, 1973).

"A Note on the Exegesis of Ecclesiastes 3 15b," ZAW 88 (1976) 419-20.

\section{F. H. Sandbach}

The Stoics (London: Chatto \& Windus, 1975)

\section{J. de Savignac}

"La sagesse du Qôhéléth et l'épopée de Gilgamesh," VT 28 (1978) 318-323.

\section{A. Schoors}

"The Use of Vowel Letters in Qoheleth," UF 20 (1988) 277-86.

\section{R. B. Y. Scott}

Proverbs Ecclesiastes (AB 18; Garden City: Doubleday, 1965).

\section{L. Seow}

"The Socioeconomic Context of 'The Preacher's' Hermeneutic," PSB NS 17 (1996) 168-95.

"Linguistic Evidence and the Dating of Qohelet," JBL 115 (1996) 643-666.

Ecclesiastes (AB 18C; Garden City: Doubleday, 1997).

\section{G. Siegfried}

"Review of T. Tyler, Ecclesiastes," ZWT (1875) 284-91. 
"Der jüdische Hellenismus," ZWT (1875) 469-89.

Prediger und Hoheslied (HAT II, 3/2; Göttingen: Vandenhoeck \& Ruprecht, 1898).

\section{W. Staples}

"The Meaning of hepeșin Ecclesiastes," JNES 24 (1965) 110-12.

"Profit in Ecclesiastes," JNES 4 (1945) 87-96.

\section{E. Stern}

Material Culture of the Land of the Bible in the Persian Period 538-332 B.C. (Warminster: Aris \& Phillips, 1982).

"The Archæology of Persian Palestine," in W. D. Davies \& L. Finkelstein (eds.), The Cambridge History of Judaism Vol. 1: The Persian Period (Cambridge: C.U.P., 1984).

\section{E. Stone}

"Lists of Revealed Things in the Apocalyptic Literature," in F. M. Cross et al. (eds.), Magnalia Dei: The Mighty Acts of God (Garden City: Doubleday, 1976) 41452.

\section{Strange}

The Question of Moderation in Eccl 7:15-18 (S.T.D. Diss; Catholic University of America, 1969).

\section{A. Strobel}

Das Buch Prediger (Kohelet) (Düsseldorf: Patmos, 1967).

\section{W. W. Tarn \& G. T. Griffith}

Hellenistic Civilization (London: Methuen, 1959).

R. Taylor

"Determinism," in P. Edwards (ed.), Encyclopedia of Philosophy (London \& New York: Macmillan, 1967-72).

V. Tcherikover

Hellenistic Civilization and the Jews (Philadelphia: Jewish Publication Society of 
America; Jerusalem: Magnes, 1959).

T. H. Tobin

"Logos," in $A B D$ 4.348-56.

C. C. Torrey

“The Question of the Original Language of Qohelet," JQR 39 (1948-9) 151-60.

C. H. Toy

Proverbs (ICC; Edinburgh: Clark, 1899).

J. L. Trafton

"Solomon, Psalms of," in ABD 6.115-17.

M. Tsevat

"קלח (II)," in TDOT 4.447-51.

T. Tyler

Ecclesiastes (London: Williams \& Norgate, 1874).

A. Verheij

"Paradise Retried: On Qohelet 2:4-6," JSOT 50 (1991) 113-115.

C. F. Whitley

Koheleth: His Language and Thought (BZAW 148; Berlin \& New York: de Gruyter, 1979).

R. N. Whybray

"Qoheleth the Immoralist? (Qoh 7:16-17)" in J. G. Gammie et al. (eds.), Israelite Wisdom: Essays in Honor of Samuel Terrien (Missoula: Scholars, 1978) 191-204.

"Qoheleth, Preacher of Joy," JSOT 23 (1982) 87-98.

"Ecclesiastes 1.5-7 and the Wonders of Nature," JSOT 41 (1988) 105-112.

Ecclesiastes (NCBC; Grand Rapids: Eerdmans; London: Marshall, Morgan \& Scott, 1989).

Ecclesiastes (OTG; Sheffield: JSOT, 1989). 
The Composition of the Book of Proverbs (JSOTSup 168; Sheffield: JSOT, 1994). "Qoheleth as Theologian" in A. Schoors (ed.), Qohelet in the Context of Wisdom (BETL; Leuven: Leuven University/Peeters, 1998).

\section{G. Wildeboer}

Der Prediger in K. Budde (ed.), Die füf Megillot (KHAT 17; Freiburg: Mohr, 1898).

\section{R. J. Williams}

"The Sages of Ancient Egypt in the Light of Recent Scholarship," JAOS 101 (1981) $1-19$.

\section{A. S. Van der Woude}

Micah (Nijkerk: Callenback, 1976).

\section{A. G. Wright}

"'For Everything There is a Season': The Structure and Meaning of the Fourteen Opposites (Ecclesiastes 3, 2-8)," in J. Doré et al. (eds.), De la Tôrah au Messie. Mélanges Henri Cazelles (Paris: Gabalda, 1981) 321-28.

\section{H. H. Wright}

The Book of Koheleth (London: Hodder \& Stoughton, 1883).

\section{A. Yarbro Collins (ed.)}

Early Christian Apocalypticism (Semeia 36; Decatur: Scholars, 1986).

\section{R. Yaron}

"Aramaic Marriage Contracts from Elephantine," JSS 3 (1958) 9-10.

"Aramaic Deeds of Conveyance," Bib 41 (1960) 248-71.

\section{W. Zimmerli}

Der Prediger (ATD 16/1; Göttingen: Vandenhoeck \& Ruprecht, 1962).

\section{F. Zimmerman}

“The Aramaic Provenance of Qohelet," JQR 36 (1945-6) 17-45. 